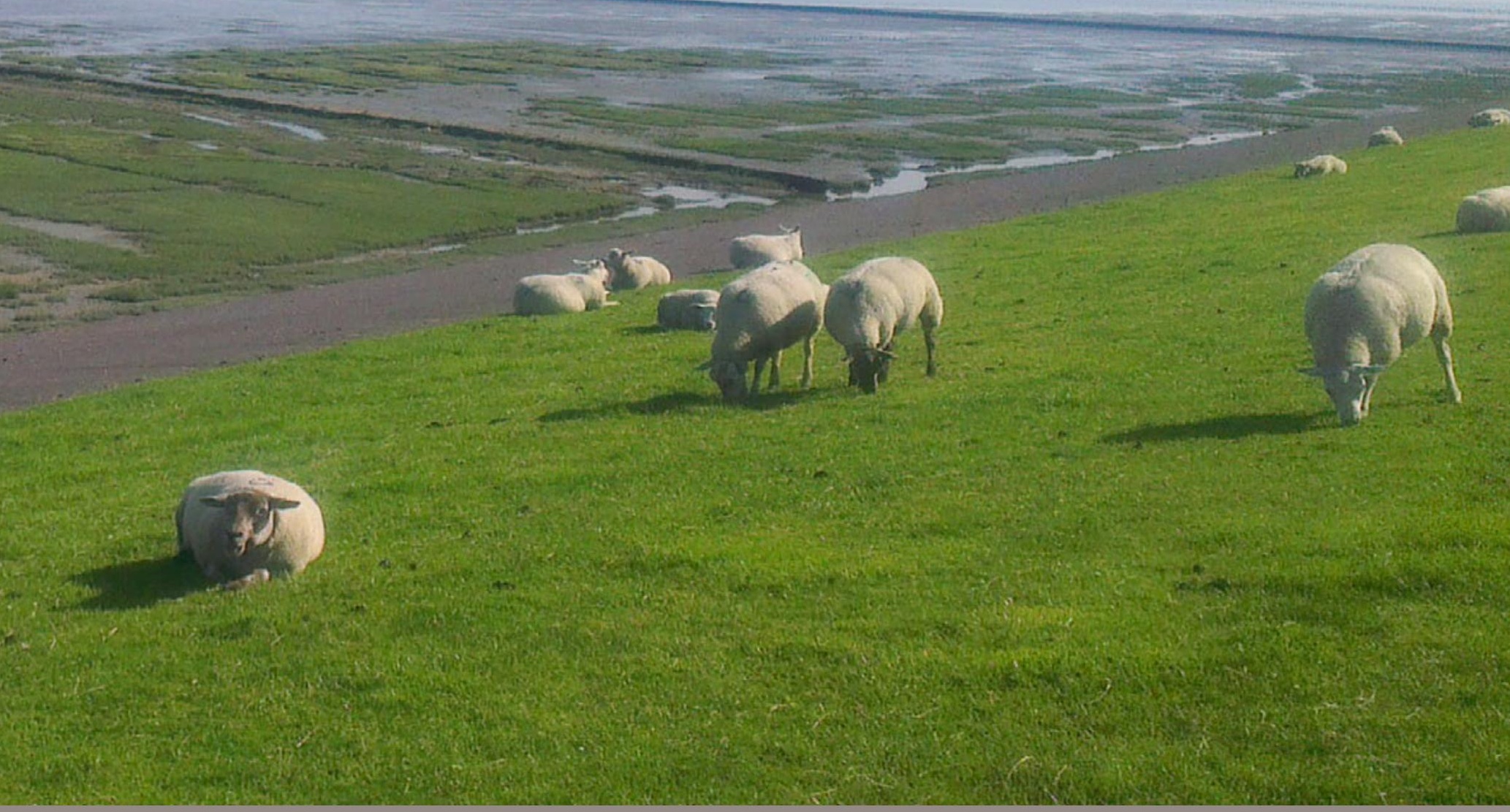

\title{
Lange-termijnontwikkeling van kwelders in de Waddenzee (1960-2018)
}

K. Elschot, M.E.B. Van Puijenbroek, D.D.G. Lagendijk, 

Lange-termijnontwikkeling van kwelders in de Waddenzee (1960-2018) 
Dit WOt-technical report is gemaakt conform het Kwaliteitsmanagementsysteem (KMS) van de unit Wettelijke Onderzoekstaken Natuur \& Milieu, onderdeel van Wageningen University \& Research.

De WOT Natuur \& Milieu voert wettelijke onderzoekstaken uit op het beleidsterrein natuur en milieu. Deze taken worden uitgevoerd om een wettelijke verantwoordelijkheid van de Minister van Landbouw, Natuur en Voedselkwaliteit (LNV) te ondersteunen. We zorgen voor rapportages en data voor (inter)nationale verplichtingen op het gebied van agromilieu, biodiversiteit en bodeminformatie, en werken mee aan producten van het Planbureau voor de Leefomgeving zoals de Balans van de Leefomgeving.

\section{Disclaimer WOt-publicaties}

De reeks 'WOt-technical reports' bevat onderzoeksresultaten van projecten die kennisorganisaties voor de unit Wettelijke Onderzoekstaken Natuur \& Milieu hebben uitgevoerd.

WOt-technical report 182/WMR-rapport C023/20 is het resultaat van onderzoek gefinancierd door het ministerie van Landbouw, Natuur en Voedselkwaliteit (LNV). 


\section{Lange-termijnontwikkeling van kwelders in de Waddenzee (1960-2018)}

Kelly Elschot ${ }^{1}$, Marinka van Puijenbroek ${ }^{1}$, Georgette Lagendijk ${ }^{1}$, Jan-Tjalling van der Wal $^{1}$ en Cor Sonneveld ${ }^{1}$

1 Wageningen Marine Research

Projectnummer WOT-04-009-035.02

Wettelijke Onderzoekstaken Natuur \& Milieu

Wageningen, augustus 2020

WOt-technical report 182

WMR-rapport C023/20

ISSN 2352-2739

DOI $10.18174 / 521727$ 


\section{Referaat}

Elschot K., M.E.B. Van Puijenbroek, D.D.G. Lagendijk, J-T. Van der Wal, C. Sonneveld (2020). Langetermijnontwikkeling van kwelders in de Waddenzee (1960-2018). Wettelijke Onderzoekstaken Natuur \& Milieu, WOt-technical report 182/ Wageningen Marine Research rapport C023/20. 100 blz.; 22 fig.; 6 tab.; 73 ref; 6 Bijlagen.

Kwelders zijn onderdeel van het Natura 2000-gebied Waddenzee. Om aan (inter-)nationale verplichtingen te voldoen is actuele kennis van areaal en kwaliteit vereist. Het kwelderareaal in de Waddenzee is in het afgelopen decennium geleidelijk gegroeid en daarmee wordt aan de instandhoudingsdoelstelling voldaan. Autonome successie op de Waddeneilanden en een toename van lage kwelder met pioniersoorten langs de vastelandskust duiden op een (toekomstige) afname van kwaliteit. Dit moet nauwlettend gemonitord worden om de beheerders en eigenaren te kunnen adviseren over mogelijke (noodzakelijke) ingrepen. Het areaal aan pionierzone in de Waddenzee is relatief stabiel. Langs de Groninger kust worden de eerste effecten van het kwelderherstelplan zichtbaar in de vorm van een afname van door zeekweek gedomineerde midden kwelder. De opslibbing op de verschillende Waddenzeekwelders is voldoende om mee te groeien met de huidige zeespiegelstijging. Een toekomstige versnelling kan tot problemen leiden op de Waddeneilanden en op kwelderdelen verder weg van de sedimentbron.

Trefwoorden: beheer, kwelders, opslibbing, Waddenzee, schorren, sedimentatie, zeespiegelstijging

\section{Abstract}

Elschot K., M.E.B. Van Puijenbroek, D.D.G. Lagendijk, J-T. Van der Wal, C. Sonneveld (2020). Long-term development of salt marsh in the Wadden Sea (1960-2018). Wageningen, The Statutory Research Task Unit for Nature and the Environment (WOT Natuur \& Milieu), WOt-technical report 182/Wageningen Marine Research rapport C023/20. 100 p.; 22 Figs; 6 Tabs; 72 Refs; 6 Appendices.

An important component of the Wadden Sea Natura 2000 site are the salt marshes. Up-to-date information on the area and quality of the salt marshes is needed in order to meet national and international obligations. The salt marsh area has gradually increased over the past decade and the conservation objective has been met. However, autonomous succession of the vegetation on the barrier islands and an increase in cover of pioneer plants in the low marshes along the mainland coast indicate that the quality of the marsh ecosystem could decrease in the future. This must be closely monitored to advise managers and landowners about interventions that may be necessary. The area of the pioneer zone is relatively stable. The first effects of a salt marsh recovery plan - a decrease in Elytrigia atherica dominated marsh - can be seen along the Groningen coast. The marsh accretion rates on the various Wadden Sea salt marshes are sufficient to keep up with the current sea level rise. Accelerated sea-level rise in future could lead to problems, especially on the barrier islands and on salt marshes furthest away from the sediment source.

Keywords: management, salt marsh, sedimentation, Wadden Sea, coastal habitat, marsh accretion, sea-level rise

Foto omslag: Kelly Elschot

\section{(C) 2020 Wageningen Marine Research}

Postbus 57, 1780 AB Den Helder

Tel: (0317) 4809 00; e-mail: marine-research@wur.nl

Wettelijke Onderzoekstaken Natuur \& Milieu (unit binnen de rechtspersoon Stichting Wageningen Research), Postbus 47, 6700 AA Wageningen, T 03174854 71, info.wnm@wur.nl, www.wur.nl/wotnatuurenmilieu.

WOT Natuur \& Milieu is onderdeel van Wageningen University \& Research.

Dit rapport is gratis te downloaden van https://doi.org/10.18174/521727 of op www.wur.nl/wotnatuurenmilieu. De WOT Natuur \& Milieu verstrekt geen gedrukte exemplaren van rapporten.

- Overname, verveelvoudiging of openbaarmaking van deze uitgave is toegestaan mits met duidelijke bronvermelding.

- Overname, verveelvoudiging of openbaarmaking is niet toegestaan voor commerciële doeleinden en/of geldelijk gewin.

- Overname, verveelvoudiging of openbaarmaking is niet toegestaan voor die gedeelten van deze uitgave waarvan duidelijk is dat de auteursrechten liggen bij derden en/of zijn voorbehouden.

Wettelijke Onderzoekstaken Natuur \& Milieu aanvaardt geen aansprakelijkheid voor eventuele schade voortvloeiend uit het gebruik van de resultaten van dit onderzoek of de toepassing van de adviezen. 


\section{Woord vooraf}

Dit rapport is mede tot stand gekomen met bijdragen van leden van de Werkgroep Kwelderwerken met dank aan Aante Nicolai (Rijkswaterstaat (RWS)), Hessel Jongerius (RWS), Marieke van Woensel (RWS), Diny Dijk (RWS), Albert Wester (It Fryske Gea (IFG)), Jan-Jelle Jongsma (IFG), Arjan Hendriks (Stichting Het Groninger Landschap (SGL) en vertegenwoordiger Natuurmonumenten (NM)) en Willem van Duin (Artemisia-kwelderonderzoek). 



\section{Inhoud}

Woord vooraf

Samenvatting

Summary

1 Introductie

$\begin{array}{llr}1.1 & \text { Kwelders in de Waddenzee } & 13\end{array}$

$\begin{array}{lll}1.1 .1 & \text { Inleiding } & 13\end{array}$

$\begin{array}{lll}1.1 .2 & \text { Zeespiegelstijging } & 14\end{array}$

1.1.3 Kwelderontwikkeling en vegetatiezoneringen $\quad 15$

1.2 Doelen en richtlijnen 16

1.2.1 Natura 2000 en Kaderrichtlijn Water (KRW) 16

1.2.2 Trilaterale Waddenzee-overeenkomst (TWO) 16

1.2.3 Functie-eisen Rijkswaterstaat $\quad 16$

$\begin{array}{ll}1.3 \text { Kennisvragen } & 17\end{array}$

2 Kweldermonitoring (methoden) $r$

$\begin{array}{llr}2.1 & \text { VEGWAD-vegetatiekarteringen } & 19\end{array}$

2.2 Meetvakken (kwelderwerken) 19

2.3 Wageningse SEB-meetnet langs de Friese en Groninger kust 22

$\begin{array}{lll}2.4 & \text { Beheer en onderhoud } & 24\end{array}$

$\begin{array}{lll}2.4 .1 & \text { Onderhoud rijzendammen } & 24\end{array}$

$\begin{array}{lll}2.4 .2 & \text { Grondwerk } & 25\end{array}$

$\begin{array}{lll}2.4 .3 & \text { Beweiding } & 25\end{array}$

$\begin{array}{llr}3 & \text { Vegetatieontwikkelingen } & 27\end{array}$

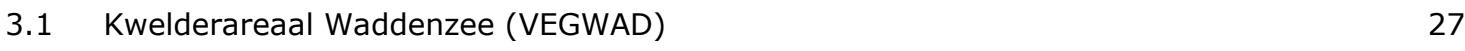

3.2 Vegetatieontwikkeling kwelderwerken 1960 - $2018 \quad 29$

3.2.1 Toetsing aan de functie-eisen van RWS 29

3.2.2 Vegetatieontwikkeling kwelderwerken 1960 - 2018 (meetvakken) 31

3.2.3 Trends in plantendiversiteit binnen de kwelder (meetvakken) 33

3.2.4 Vergelijking VEGWAD-karteringen met meetvakgegevens $\quad 35$

3.2.5 Zeegras binnen de meetvakken $\quad 36$

$4 \quad$ Ontwikkelingen maaiveldhoogte $\quad 37$

$\begin{array}{lll}4.1 & \text { Sedimentdynamiek en kwelders in de Waddenzee } & 37\end{array}$

4.2 Maaiveldhoogteontwikkelingen kwelderwerken 1960-2018 (meetvakken) 38

4.3 Opslibbing gerelateerd aan kwelderzone (SEB-meetnet) 41

4.4 Effecten van beweiding op de opslibbing (SEB-meetnet) 42

5 Conclusies en aanbevelingen $\quad 47$

$\begin{array}{lll}5.1 & \text { Kwelderareaal en plantendiversiteit } & 47\end{array}$

$\begin{array}{lll}5.1 .1 & \text { Kwelders in de Waddenzee } & 47\end{array}$

5.1.2 Functie-eisen Rijkswaterstaat (kwelderwerken) $\quad 47$

\begin{tabular}{ll}
5.2 & Maaiveldontwikkeling en zeespiegelstijging \\
\hline
\end{tabular}

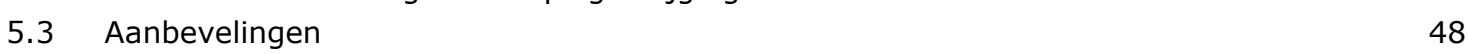


Bijlage 1 Monitoringsprogramma VEGWAD

Bijlage 2 Meetvaknummers verdeeld over provincie, deelgebied en polder van west naar oost binnen de kwelderwerken

Bijlage 3 Opname meetvakken maaiveldhoogte en damrenovatie Terugtrekken van de vegetatiegrens richting dijk voorbij de 'afgepaalde' kweldergrens

Bijlage 5 Visuele weergave van de veranderingen in de kweldervegetatie tussen 1960 en 2018 per meetvak

Bijlage 6 Maaiveldverandering weergegeven per individueel meetvak 1965-2018 


\section{Samenvatting}

De Nederlandse Waddenzee vormt samen met de Duitse en Deense delen een ca. 900.000 ha groot, aaneengesloten intergetijde-kustgebied. Het heeft de status van UNESCO-Werelderfgoed en is het grootste Natura 2000-gebied in Nederland. Er gelden diverse nationale en internationale natuurdoelstellingen. In het Nederlandse deel van de Waddenzee liggen ca. 9.000 ha aan kwelders, waarvan ongeveer de helft op de Waddeneilanden en de helft aan de Groninger en Friese vastelandskust, in de zogenoemde kwelderwerken. Klimaatverandering en de daaruit voortkomende zeespiegelstijging vormen een mogelijke bedreiging voor deze kwelders. Om aan de nationale en internationale rapportageverplichtingen te kunnen voldoen is actuele kennis van de kwantiteit en kwaliteit van de kwelders in de Waddenzee nodig. Daarnaast is er vanuit de eigenaren en beheerders behoefte aan terugkoppeling van de actuele status van de kwelders om de effecten van genomen beheermaatregelen te kunnen bepalen. Dit gebeurt aan de hand van vier functie-eisen, opgesteld door Rijkswaterstaat (Dijk 2020):

1. Het totale areaal van de jonge kwelder in Friesland en Groningen bedraagt minstens 1.250 ha (gemiddeld over de laatste vijf jaren). Hiervan ligt minstens een derde (420 ha) in elke provincie.

2. De actuele kweldergrens mag nergens verder teruggaan dan tot de oorspronkelijke grens van particulier eigendom (de 'oude' kwelder, ook wel de 'afgepaalde kweldergrens').

3. Minimaal 750 ha pionierzone met een vegetatiebedekking $>5 \%$ binnen de kwelderwerken, voor beide provincies samen.

4. Waterplassen en kale plekken op de kwelder die zijn ontstaan als gevolg van stagnatie in de waterafvoer, mogen per geval niet groter zijn dan 0,1 ha en gezamenlijk niet groter dan $5 \%$ van het totale oppervlakte.

In de voorliggende rapportage worden de resultaten van drie datareeksen gepresenteerd, bestaande uit lange-termijnopslibbing- en vegetatiegegevens:

1. de zes-jaarlijkse VEGWAD-vegetatiekarteringen van RWS, die vlakdekkend van alle kwelders in Nederland worden gemaakt (Waddenzee: 1999-2017);

2. de gegevens van de meetvakken van RWS, waarvan ieder jaar de vegetatie en elke drie jaar hoogtetransecten worden opgenomen. De dataset omvat vijfentwintig vakken, elk 400m breed, die van dijk tot wad verspreid in de kwelderwerken langs de Groninger en Friese kust liggen (1960-2018);

3. de gegevens van het Wageningse SEB-meetnet, met jaarlijkse metingen van opslibbing en vegetatieverandering op 136 punten verspreid over vier locaties in de kwelderwerken (19942018).

Uit historische vegetatiekarteringen blijkt dat het kwelderareaal in de Waddenzee een dieptepunt bereikte in de twintigste eeuw, maar in het afgelopen decennium geleidelijk weer is toegenomen. Dit komt door natuurlijke uitbreiding van de kwelders op de Waddeneilanden naar het oosten, door aangroei van de vastelandskwelders en door enkele ontpolderingsprojecten langs de Friese kust. Op de Waddeneilanden neemt binnen de kwelderzone het aandeel brakke kwelder en hoge kwelder met zeekweek toe door autonome successie, terwijl deze in de Dollard afnemen onder invloed van beweiding en vernatting. Langs de kust zien we een geleidelijke uitbreiding van de kwelder richting de buitenste nog in onderhoud zijnde rijzendammen, waardoor de pionierzone in de knel komt en afneemt. Binnen de kwelderzone in Friesland neemt het areaal aan lage kwelder met pioniersoorten toe, mogelijk door een toename in beweidingsdruk gecombineerd met verminderde drainage. In Groningen worden de eerste effecten van het kwelderherstelplan zichtbaar (uitgevoerd in de periode 2011-2013): een toename in beweiding resulteert in een afname van door zeekweek gedomineerde midden kwelder ten gunste van lage kwelder.

De Friese en Groninger kwelders langs de kust samen (i.e. de kwelderwerken) zijn getoetst aan drie van de vier functie-eisen die de richtlijn vormen voor het beheer en onderhoud van RWS: 
1. het huidige kwelderareaal van 4.334 ha binnen de kwelderwerken voldoet ruimschoots aan de gestelde eis van 1.250 ha;

2. op drie locaties langs de Groninger kust is de kweldergrens iets voorbij de oude afgepaalde kweldergrens teruggetrokken richting dijk, waarmee niet volledig is voldaan aan de betreffende eis;

3. het huidige areaal aan pionierzone van 1.020 ha voldoet aan de gestelde eis van 750 ha;

4. functie-eis $4 \mathrm{zal}$ na overleg met de beheerders en gebruikers worden getoetst.

In de Waddenzee worden verschillende initiatieven genomen voor het herstel van zeegrasvelden. Daarom is in dit rapport een extra inventarisatie gemaakt van de aanwezigheid van zeegrassen binnen de meetvakken. Daaruit blijkt dat ze aanwezig zijn in de Groninger meetvakken, en dat het aantal sub-vakken waarin ze voorkomen flink is toegenomen in de periode 2012-2018.

De kwelders in de Waddenzee hogen gemiddeld met enkele millimeters (Waddeneilanden) tot enkele centimeters (vastelandskust) per jaar op en kunnen meegroeien met de huidige zeespiegelstijging. Als de stijging versneld optreedt, zoals verschillende klimaatscenario's voorspellen, dan zullen mogelijk niet alle kwelders kunnen meegroeien en 'verdrinken'. Eilandkwelders met een lage sedimentatiesnelheid, kwelders waar bodemdaling plaatsvindt en de landinwaarts gelegen kwelderdelen die ver van de sedimentbron verwijderd liggen, zullen de grootste risico's lopen.

Voor de kwelders in de Waddenzee kan geconcludeerd worden dat het areaal aan kwelders in de Waddenzee is toegenomen en daarmee wordt voldaan aan de behoudsdoelstelling van $\mathrm{H} 1330 \mathrm{~A}$. Autonome successie op de Waddeneilanden en een toename van lage kwelder met pioniersoorten langs de vastelandskust duiden op een (toekomstige) afname van kwaliteit. Het areaal aan pionierzone in de Waddenzee is relatief stabiel, ondanks een afname langs de Friese kust. De opslibbing op de verschillende Waddenzeekwelders is voldoende om mee te groeien met de huidige zeespiegelstijging. Een toekomstig versnelling kan mogelijk tot problemen leiden op de Waddeneilanden en kwelderdelen verder weg van de sedimentbron.

In het voorliggende rapport worden enkele kennislacunes geïdentificeerd en daarom worden de volgende aanbevelingen gedaan:

1. Nader overleg is nodig met beheerders en gebruikers van kwelders over functie-eis 4 van RWS: "Waterplassen en kale plekken op de kwelder die zijn ontstaan als gevolg van stagnatie in de waterafvoer, mogen per geval niet groter zijn dan 0,1 ha en gezamenlijk niet groter dan $5 \%$ van het totale oppervlakte".

2. Verdere studies naar de klimaatadaptatie van kwelders in relatie tot zeespiegelstijging worden aanbevolen. Om de effecten van klimaatverandering op kwelders te kunnen voorspellen is langlopende monitoring nodig, waarbij niet alleen verticale groei maar ook laterale kweldergroei meegenomen wordt.

3. Het habitattype H1310 (zilte pionierbegroeiingen) in de Waddenzee wordt gedomineerd door eenjarige zeekraal, en het areaal varieert sterk van jaar op jaar. Om toekomstige effecten van klimaatverandering beter te kunnen voorspellen is onderzoek nodig naar de effecten van externe factoren (zoals winterstormen) op de vestiging van zeekraal in het groeiseizoen.

4. Verdere monitoring met eventueel extra onderzoek is nodig om de uitbreiding van lage kwelder met pioniersoorten in de vastelandskwelders te begrijpen. De vervanging van meerjarige plantensoorten door eenjarige kan in de toekomst tot kale plekken en erosie leiden en daarmee een afname in kwelderkwaliteit. 


\section{Summary}

The Dutch, German and Danish parts of the Wadden Sea together form a large intertidal coastal area of approximately 900,000 ha. It is a UNESCO World Heritage Site and the largest Natura 2000 site in the Netherlands. The area is governed by various national and international conservation objectives. In the Dutch part of the Wadden Sea there are approximately 9,000 ha of salt marsh, about half of which are on the Wadden Islands and half along the mainland coast that originate from former marsh reclamation works. Climate change and the resulting rise in sea level are a potential threat to marshes. In order to meet national and international reporting obligations, up-to-date information on the area and quality of salt marsh in the Wadden Sea is needed. In addition, the landowners and managers of the marshes along the mainland coast depend on feedback on the status of the salt marshes to determine the effects of management practices on the marshes. For this purpose, Rijkswaterstaat (RWS) has drawn up four requirements (RWS, Dijk 2020):

1. The total area of the young salt marshes in Friesland and Groningen must be at least 1,250 ha (averaged over the past five years). At least one third (420 ha) of this must be located in each province.

2. The edge of the salt marsh boundary must not recede beyond the relevant boundary of private property, known as the 'defined salt marsh boundary'.

3. At least 750 ha of pioneer zone must have a vegetation cover $>5 \%$, for both provinces together.

4. Bodies of water and bare soil within the salt marsh that have arisen as a result of stagnant water must not exceed 0.1 ha and not exceed $5 \%$ of the total area.

This report presents the results from three datasets on long-term sediment accretion and vegetation:

1. the VEGWAD vegetation surveys made by RWS of all salt marshes in the Netherlands every six years (Wadden Sea: 1999-2017);

2. the 25 RWS monitoring sections on which RWS carries out vegetation surveys each year and elevation transects every three years, comprising 25 sections, each 400m wide, distributed from the dike over the salt marshes and on to the mudflats along the Groningen and Frisian coast (1960-2018);

3. the Wageningen SEB network, with annual measurements of marsh accretion and vegetation change at 136 PQs (Permanent Quadrants) spread over four salt marshes (1994-2018).

Historical surveys show that the area of salt marsh in the Wadden Sea reached its lowest point in the twentieth century, but has gradually increased again over the past ten years or so. This is due to the natural expansion of the salt marshes on the Wadden Islands towards the east, the accretion of the mainland salt marshes and a number of depoldering projects along the Frisian coast. On the Wadden Islands, within the salt marsh zone the share of brackish and high marsh dominated by the climax species sea couch (Elytrigia atherica) is increasing due to autonomous succession, while in the Dollard these areas are decreasing under the influence of grazing and reduced drainage. Along the Frisian coast, we see a gradual expansion of the salt marsh towards the outer wooden groynes, which are still being maintained. As a result, the pioneer zone is being squeezed between the two and decreasing in area. Within the salt marsh zone, the area of low salt marsh with pioneer plants is increasing, possibly due to an increase in grazing pressure combined with less drainage. In the mainland marshes in the province of Groningen, the first effects of the salt marsh restoration plan are visible (implemented in the period 2011-2013): an increase in grazing is leading to a decrease in sea couch dominated marsh in favour of low salt marsh vegetation.

The man-made salt marshes along the mainland coast have been tested against three of the four requirements that form the guidance for the management and maintenance by RWS:

1. the current salt marsh area of 4,334 ha within the salt marsh works amply meets the requirement of 1,250 ha; 
2. at three locations along the Groningen coast, the salt marsh boundary has receded slightly beyond the old defined salt marsh boundary towards the dike, which means that the relevant requirement has not been fully met;

3. the current area of pioneer zone of 1,020 ha meets the requirement of 750 ha;

4. requirement 4 will be tested after consultation with the managers.

Various initiatives are being taken in the Wadden Sea to restore seagrass fields. That is why this report contains an extra inventory of the presence of seagrasses within the monitored sections. This shows that they are present in the Groningen sections and that the number of sub-sections in which they occur has increased considerably in the period 2012-2018.

The salt marshes in the Wadden Sea accrete on average by a few millimetres (Wadden Islands) to a few centimetres (mainland coast) per year and can keep pace with the current sea-level rise. If this increase occurs at an accelerated rate, as various climate scenarios predict, then not all salt marshes may be able to keep pace and may 'drown' in the near future. Island salt marshes with a low sedimentation rate, salt marshes where subsidence occurs and the inland salt marshes that are located far from the sediment source will be at greatest risk.

It can be concluded that the area of salt marsh in the Wadden Sea has increased and that the H1330A (Atlantic salt meadows) conservation objective has been met. Autonomous succession on the Wadden Islands and an increase in low salt marsh with pioneer plants along the mainland coast indicate a potential decrease in quality. The area of the pioneer zone in the Wadden Sea is relatively stable, despite a decrease along the Frisian coast. The accretion rate on the various Wadden Sea salt marshes is sufficient to maintain growth with the current rate of sea-level rise. An increase in the rate of sealevel rise in future could lead to problems on the Wadden Islands and salt marshes further away from the source of sediment.

The report identifies some knowledge gaps and therefore the following recommendations are made:

1. Further consultation is required with managers and owners of the salt marshes along the mainland coast about RWS requirement 4: 'Bodies of water and bare soil within the salt marsh that have arisen as a result of stagnant water must not exceed 0.1 ha and not exceed $5 \%$ of the total surface.'

2. Further studies on the climate adaptation of salt marshes in relation to sea-level rise are recommended. Predicting the effects of climate change on salt marshes requires long-term monitoring, which includes not only vertical growth but also lateral salt marsh expansion.

3. Habitat type H1310 (Salicornia and other annuals colonising mud and sand) in the Wadden Sea is dominated by the annual plant Salicornia procumbens and the area varies greatly from year to year. To better predict future effects of climate change, research is needed into the effects of external factors (such as winter storms) on their successful establishment and coverage in the pioneer zone.

4. Further monitoring and possibly additional research is needed to understand the expansion of pioneer plants into the low marsh along the mainland coast. The replacement of perennial plant species by annuals can lead to bare spots and erosion in the future, and thus to a decrease in salt marsh quality. 


\section{$1 \quad$ Introductie}

\subsection{Kwelders in de Waddenzee}

\subsubsection{Inleiding}

In de internationale Waddenzee liggen 31.500 ha aan kwelders en bijna 8.000 ha aan pionierzone (Baptist et al. 2019a). Samen is dit bijna 40.000 ha waarvan circa 9.000 ha in het Nederlandse deel van de Waddenzee ligt (Esselink et al. 2017). De helft ligt verdeeld over de verschillende Waddeneilanden en de andere helft langs de Noord-Hollandse, Groninger en Friese vastelandskust (figuur 1.1). Vrijwel alle kwelders langs de kust, inclusief de Dollard, zijn half-natuurlijke kwelders en komen voort uit de vroegere landaanwinningswerken (Dijkema 1987a). Deze kwelders zijn zeer slikkig, hebben een dikke kleilaag en doorgaans een hoge sedimentatiesnelheid (Dijkema 1987a, Dijkema et al. 2013). Kwelders op de Waddeneilanden zijn van (min of meer) natuurlijke oorsprong en bevinden zich vooral op de eilandstaarten (de Groot et al. 2017). Deze zandige kwelders hebben een geringe kleidikte, tot circa $60 \mathrm{~cm}$ dikte, op een onderliggende zandbodem (de Groot et al. 2011). Er is een lage sedimentatiesnelheid van enkele mm per jaar, die met de hoogte en leeftijd van de kwelder afneemt (van Wijnen en Bakker 2001, Elschot et al. 2015).

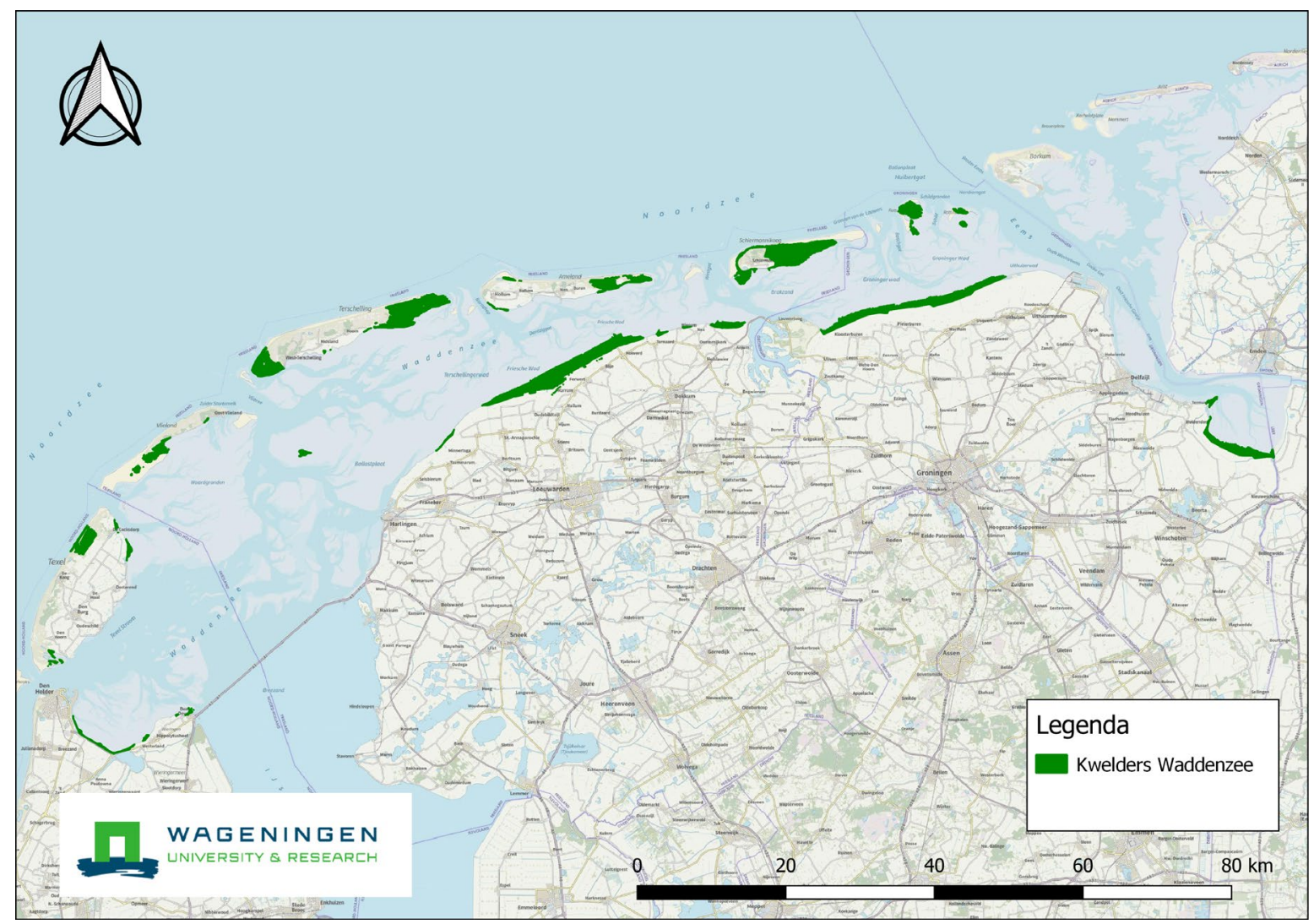

Figuur 1.1 Kwelders in het Nederlandse deel van de Waddenzee gebaseerd op de VEGWADvegetatiekarteringen 2010-2017. Oppervlakten zijn bepaald op basis van de TMAP-typologie (Petersen et al. 2014) waarbij H1330a (Atlantische schorren en zilte graslanden), H1310 (Zilte pionierbegroeiingen) en $\mathrm{H} 1320$ (Slijkgrasvelden) zijn samengenomen.

Kwelders herbergen een unieke flora en fauna (Doody 2008) en leveren daarmee een belangrijke bijdrage aan de biodiversiteit van Nederland. Er komen veel karakteristieke plantensoorten voor, zoals langarige zeekraal (Salicornia procumbens), kortarige zeekraal (Salicornia europaea) en zulte (Aster 
tripolium), die zich kunnen vestigen in zoute en doorgaans anoxische bodems. Door hun ligging zijn kwelders ook belangrijke rust-, broed- en foerageergebieden voor veel verschillende kustvogels (Van Roomen et al. 2017) en kwelder-specifieke invertebraten (Rickert et al. 2018). Naast een bijdrage aan de biodiversiteit kunnen kwelders nog andere belangrijke ecosysteemdiensten leveren, zoals kustverdediging (Temmerman et al. 2013, Vuik et al. 2016), koolstofopslag (McLeod et al. 2011, Elschot et al. 2015) en zware-metalenfiltering (Teuchies et al. 2013). Daarnaast zijn ze een kraamkamer voor vissen (Whitfield 2017).

Kwelders komen steeds meer in de belangstelling te staan als een natuurlijke vorm van kustverdediging en zijn nu een cruciaal onderdeel van verschillende 'building with nature'-projecten (Temmerman et al. 2013, Boorman en Hazelden 2017, Baptist et al. 2019b). De gradiënt van het kwelderprofiel (en dus de mate van opslibbing en hoogte van het voorland) draagt bij aan de effectiviteit van de golfdempende werking van kwelders (Van Loon-Steensma en Vellinga 2013, Vuik et al. 2016). De vegetatie speelt een grote rol in de golfdemping en de bescherming van de kust, waarbij het effect toeneemt met de stugheid en dichtheid van de vegetatie (Neumeier en Amos 2006, Bouma et al. 2007, Tempest et al. 2015). Door kwelders in te zetten als onderdeel van de kustverdediging zijn er minder hoge en brede dijken nodig (Vuik et al. 2016), wat meer ruimte voor de natuur met zich meebrengt. Kwelders zijn kosteneffectief, duurzamer en natuurvriendelijker dan andere kustverdedigingstechnieken (Temmerman et al. 2013, Vuik et al. 2019), waardoor ze aantrekkelijk zijn als onderdeel van de kustverdediging.

\subsubsection{Zeespiegelstijging}

De zeespiegelstijging vormt een bedreiging voor kwelders wereldwijd (FitzGerald et al. 2008). Sinds 1960 is de zeespiegel in de Waddenzee gemiddeld met $2 \mathrm{~mm}$ per jaar gestegen (figuur 1.2). In totaal is het gemiddeld hoog water (GHW) sinds 1960 tot nu met ongeveer $11 \mathrm{~cm}$ toegenomen. Kwelders moeten minimaal even snel ophogen om een vergelijkbare inundatiefrequentie te behouden. Een toename in inundatie kan leiden tot een verandering in kwelderzoneringen, waarbij vegetatietypen van hoger gelegen kwelderzoneringen veranderen naar die van een lagergelegen zonering. Bij een langdurig toenemende inundatiefrequentie kan dit uiteindelijk leiden tot kwelderverlies. De kwelders zullen dan landinwaarts uitbreiden, maar voor veel kwelders is dit onmogelijk door de aanwezigheid van dijken. Dit wordt ook wel coastal squeeze genoemd (Doody 2013).

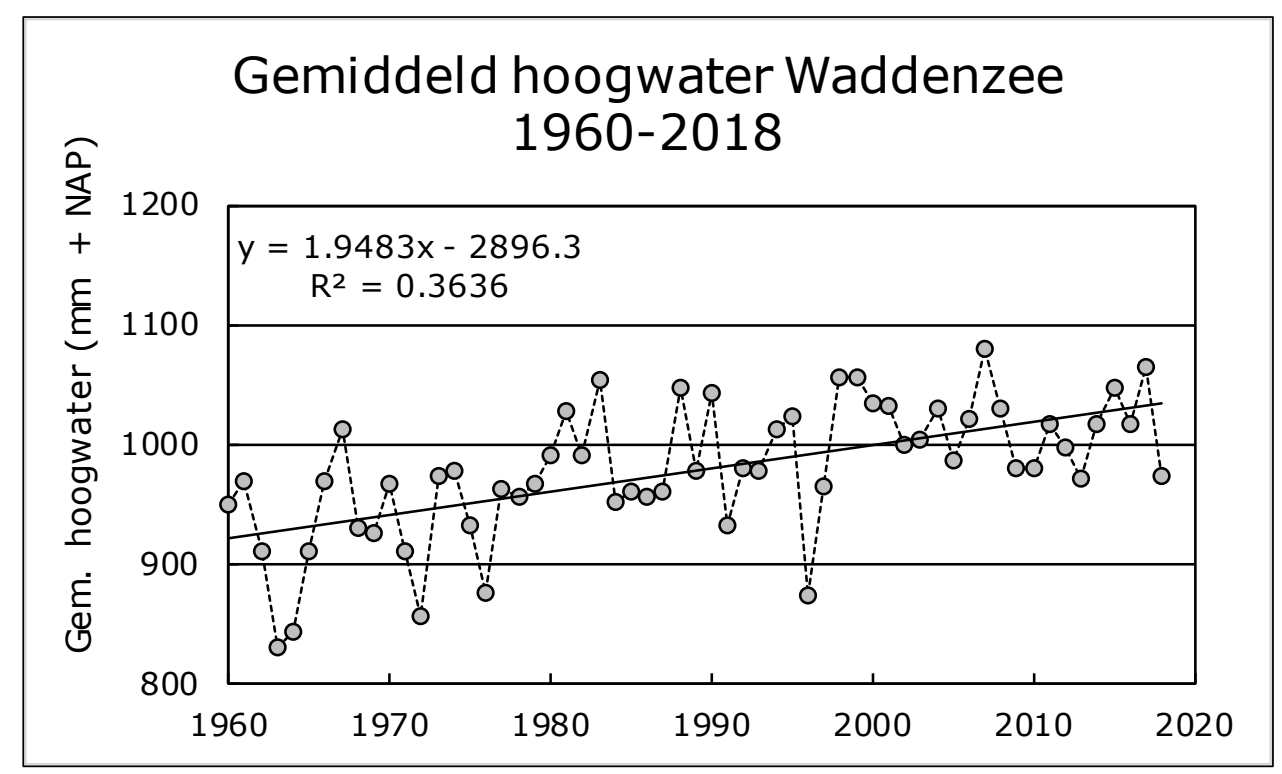

Figuur 1.2 Gemiddeld hoogwater (GHW) tussen 1960 en 2018 in het Nederlandse deel van de Waddenzee. De waarden zijn gemiddeld over drie meetstations: Harlingen, Nes en Schiermonnikoog. De huidige zeespiegelstijging bedraagt gemiddeld 1,95 $\mathrm{mm}$ per jaar.

Of kwelders voldoende ophogen hangt af van de interactie tussen sedimentaanvoer, accumulatie van organisch materiaal, inundatie en de aanwezigheid van planten (Kirwan et al. 2010). Sediment bevindt zich in suspensie in het water en wordt afgezet wanneer een kwelder gedurende hoogwater 
overstroomt (sedimentatie). Het meeste sediment wordt afgezet gedurende najaars- en winterstormen (Cahoon 2006, figuur 1.3), daarnaast wordt met elk hoog tij een klein beetje sediment afgezet. Ruige, stugge vegetatie kan dit proces van opslibbing positief beïnvloeden door de stroming af te remmen, waardoor het gesuspendeerde sediment meer kans krijgt om op het maaiveld te bezinken (Mudd et al. 2010). Naast minerale sedimentatie zorgt de accumulatie van dood organisch materiaal voor een positieve maaiveldverandering (Kirwan en Guntenspergen 2012). Levende plantenwortels houden het bezonken sediment vast en beperken erosie (Day et al. 2011). In de zomer zal onder invloed van droogte de bodem geleidelijk weer iets inklinken, wat ook wel autocompactie wordt genoemd (Cahoon et al. 2011). Dit proces wordt versterkt door vertrapping door vee (Elschot et al. 2013, Howison et al. 2017). Gezien de huidige zeespiegelstijging is het belangrijk dat het maaiveld voldoende ophoogt om mee te kunnen groeien met het stijgend gemiddeld hoogwater. Erosie en (auto-)compactie werken de ophoging tegen. Gedurende het jaar kan de kwelder onder invloed van een hoog grondwaterpeil wat zwellen en weer krimpen in periodes van droogte en een laag waterpeil (Cahoon et al. 2011).

\section{Sedimentatie- en inklinkdynamiek}

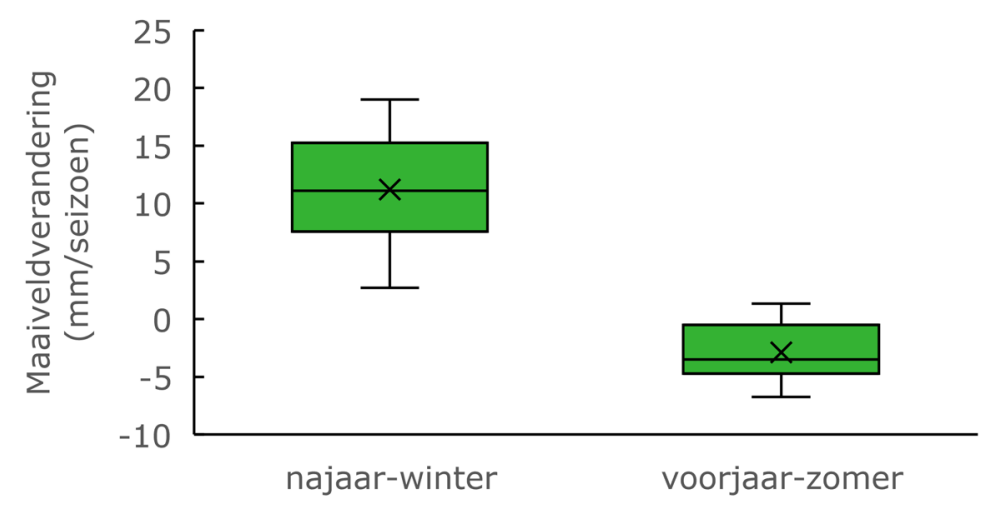

Figuur 1.3 Maaiveldverandering ten opzichte van het vorige seizoen in het najaar en de winter (ophoging door sedimentafzetting) en in het voorjaar en de zomer (daling door compactie). Waarden zijn gemiddelden over de periode 1994 en 2016 in de Negenboerenpolder. Bij 0 is de maaiveldhoogte stabiel gebleven. Bron: Wageningse SEB-meetnet.

\subsubsection{Kwelderontwikkeling en vegetatiezoneringen}

Een kwelder staat onder invloed van het getij wat in een duidelijke vegetatiezonering resulteert (Armstrong et al. 1985, Bockelmann et al. 2002). De hoogteligging en de daarmee gepaarde overstromingsfrequentie bepalen deze zonering. De pionierzone, de laagstgelegen zone, waar de meeste dynamiek heerst, wordt gekenmerkt door twee zeer stresstolerante plantensoorten: langarige zeekraal en Engels slijkgras (Spartina anglica). Op de lage kwelder komen andere zouttolerante soorten (halofyten) voor, zoals klein schorrenkruid (Suaeda maritima), gewoon kweldergras (Puccinellia maritima) en zulte of zeeaster (Aster tripolium) (Petersen et al. 2014). Hoger op de kwelder neemt over het algemeen de zouttolerantie af en de soortenrijkdom toe tot er een climaxstadium, gedomineerd door zeekweek (Elytrigia atherica), bereikt is en de plantendiversiteit weer afneemt (Veeneklaas et al. 2013). Beweiding met vee kan deze autonome plantensuccessie afremmen (Kuijper et al. 2008). De effecten van begrazing (zowel grazersoort als intensiteit waarin begraasd wordt) zijn van invloed op de aanwezige biodiversiteit. Daarom wordt tegenwoordig veelal een mozaïek van beweidingsregimes aanbevolen, inclusief delen onbeweid laten, om de biodiversiteit van kwelders te bevorderen (van Klink et al. 2016, Esselink et al. 2019a). Hierbij is wel van belang dat de effecten van beweiding via compactie van de bodem worden meegewogen. De kleibodem van een kwelder wordt ingedrukt onder het gewicht van grote grazers en dit kan een effect op de mate van maaiveldophoging of processen in de bodem zoals afbraak van organische stof (Elschot et al. 2013, 2015). 


\subsection{Doelen en richtlijnen}

\subsubsection{Natura 2000 en Kaderrichtlijn Water (KRW)}

De Waddenzee vormt samen met de Duitse en Deense delen een circa 900.000 ha groot, aaneengesloten intergetijde-kustgebied. Het heeft de status van UNESCO-Werelderfgoed en is het grootste Natura 2000-gebied in Nederland. Er gelden diverse nationale en internationale natuurdoelstellingen.

In de Waddenzee worden drie kwelderhabitattypen onderscheiden met de volgende instandhoudingsdoelstellingen (https://www.synbiosys.alterra.nl/natura2000):

H1310 Zilte pionierbegroeiingen, met de instandhoudingsdoelstelling: behoud oppervlakte en kwaliteit. H1320 Slijkgrasvelden, met de doelstelling: behoud oppervlakte en kwaliteit.

H1330 Atlantische schorren en zilte graslanden, met de doelstelling: behoud oppervlakte en verbetering kwaliteit voor subtype A (buitendijks). Voor subtype B (binnendijks) geldt de doelstelling behoud van oppervlakte en kwaliteit.

Binnen de Europese Kaderrichtlijn Water (KRW) worden kwelders als graadmeters gebruikt voor de waterkwaliteit (https://www.rijkswaterstaat.nl/water/waterbeheer/natuur-enmilieu/kwelders/index.aspx).

\subsubsection{Trilaterale Waddenzee-overeenkomst (TWO)}

Sinds de jaren zeventig van de vorige eeuw werken Nederland, Duitsland en Denemarken voor de bescherming van de Waddenzee samen. Deze trilaterale samenwerking heeft geleid tot regelmatige trilaterale government en scientific conferences, het vaststellen van gemeenschappelijke doelen in het Trilaterale Waddenzee Plan en is het Trilaterale Monitoring en Beoordelingsprogramma in het leven geroepen, in het Engels Trilateral Monitoring en Assessment Program (TMAP) genoemd. Het streven is om de monitoring in de drie landen goed op elkaar af te stemmen.

Voor de kwelders in de Waddenzee zijn Nederland, Duitsland en Denemarken de volgende doelen overeengekomen, vertaald naar het Nederlands (Trilateral Targets; Common Wadden Sea Secretariat, 2010):

1. Behoud van alle typen kwelders karakteristiek voor het Waddenzeelandschap.

2. Een toename in areaal van kwelders met natuurlijk dynamiek.

3. Een toename van natuurlijke morfologie en dynamiek, inclusief natuurlijke drainage van de vastelandskwelders op voorwaarde dat het huidige kwelderareaal behouden blijf.

4. Behoud van diversiteit in kweldervegetatie wat de geomorfologische condities van een kwelder reflecteert, inclusief variatie in vegetatiestructuur.

5. Behoud of uitbreiding van geschikte omgevingscondities voor alle typische kwelderplanten.

Vanaf 1999 wordt elke vijf jaar een Quality Status Report (QSR) geschreven waarin de status van de Waddenzee aan de trilaterale doelen is getoetst. Het meest recente QSR is in 2017 gepubliceerd (Esselink et al. 2017).

\subsubsection{Functie-eisen Rijkswaterstaat}

Het beheer en onderhoud van de kwelderwerken wordt uitgevoerd door RWS Noord-Nederland. De richtlijnen hiervoor zijn de vier functie-eisen uit het "Instandhoudingsplan: "Kwelderwerken Friese en Groninger kust" opgesteld door RWS (Dijk 2020):

1. Het totale areaal van de jonge kwelder in Friesland en Groningen bedraagt minstens 1250 ha (gemiddeld over de laatste vijf jaren). Hiervan ligt minstens een derde (420 ha) in elke provincie. 
2. De actuele kweldergrens mag nergens verder teruggaan dan tot de oorspronkelijke grens van particulier eigendom (de 'oude' kwelder, ook wel de 'afgepaalde kweldergrens').

3. Minimaal 750 ha pionierzone met een vegetatiebedekking $>5 \%$ binnen de kwelderwerken, voor beide provincies samen.

4. Waterplassen en kale plekken op de kwelder die zijn ontstaan als gevolg van stagnatie in de waterafvoer, mogen per geval niet groter zijn dan 0,1 ha en gezamenlijk niet groter dan $5 \%$ van het totale oppervlakte.

\subsection{Kennisvragen}

Om aan de nationale en internationale rapportageverplichtingen te kunnen voldoen, is actuele kennis van de kwantiteit en kwaliteit van de kwelders in de Waddenzee nodig. Daarnaast is er vanuit de eigenaren en beheerders behoefte aan terugkoppeling van de actuele status van de kwelders om de effecten van het beheer te kunnen bepalen aan de hand van de vier functie-eisen (Dijk 2020). De kwaliteit van de kweldervegetatie en kwelderaanwas, maar ook erosie van de kwelderrand, worden gemonitord (figuur 1.4).

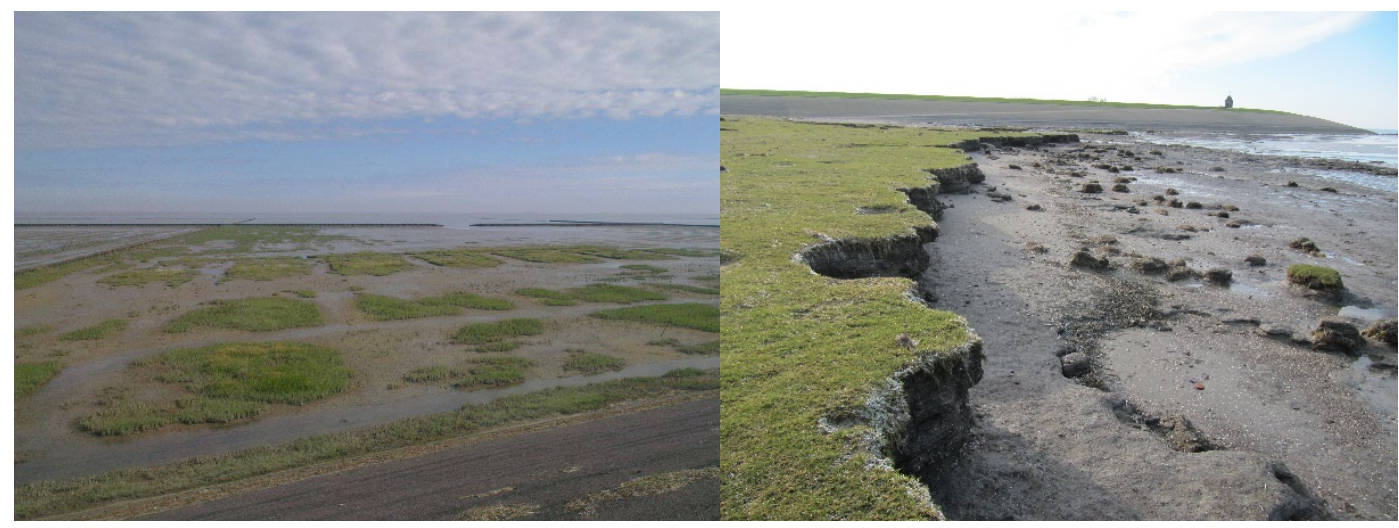

Figuur 1.4 Erosie aan de oostzijde van de kwelderwerken in de provincie Groningen (links) en de eroderende rand van de kwelder bij Wierum (rechts).

Om deze kennisvragen te kunnen beantwoorden, worden drie datasets op drie verschillende schalen geanalyseerd. Deze datasets worden in meer detail in de volgende secties behandeld. In het kort betreft het:

1) Zes-jaarlijkse VEGWAD-vegetatiekarteringen van RWS, die vlakdekkend van alle kwelders in Nederland worden gemaakt.

2) Gegevens van meetvakken van RWS, waarvan ieder jaar de vegetatie en elke drie jaar hoogtetransecten worden opgenomen. De dataset omvat 25 vakken, elk 400 meter breed, die van dijk tot wad verspreid over de kwelderwerken langs de Groninger en Friese kust liggen.

3) Gegevens van het Wageningse SEB-meetnet, met jaarlijkse metingen van opslibbing en vegetatieverandering op 136 punten verspreid over vier locaties in de kwelderwerken.

De vlakdekkende vegetatiekaarten worden geanalyseerd om de kwantiteit en kwaliteit van alle kwelders in de Waddenzee te bepalen. De analyse van de meetvakkendata en het Wageningse SEBmeetnet leveren samen actuele kennis over de ontwikkeling van de vegetatie en de opslibbing in relatie tot beheer en zeespiegelstijging. 



\section{$2 \quad$ Kweldermonitoring (methoden)}

\section{$2.1 \quad$ VEGWAD-vegetatiekarteringen}

RWS-CIV (Centrale Informatievoorziening van Rijkwaterstaat) maakt binnen het monitoringprogramma VEGWAD vegetatiekarteringen van alle kwelders in Nederland. De kaartenreeks is gestart in 1980 en is gebaseerd op een roulerend systeem waarbij elke kwelder in Nederland eenmaal per zes jaar gekarteerd wordt (bijlage 1).

Een kartering duurt in totaal drie jaar waarbij in het eerste jaar de luchtfoto's worden genomen, in jaar twee met lokale veldopnames de verschillende geïdentificeerde polygonen gevalideerd worden, en in het daaropvolgende jaar komt de kaart beschikbaar. De kartering is een landscape guided vegetation survey op basis van false colour-luchtfoto's met een resolutie van 1:5.000. De legendaeenheden worden toegewezen volgens een vaste classificatie, genaamd SALT08 (Kers 2008). Voor continuïteit gebruiken WMR en RWS deels nog de oude SALT97-classificatie (Jong et al. 1998). De VEGWAD-kaarten die geclassificeerd zijn met SALT08 worden terugvertaald naar SALT97 en doorvertaald naar TMAP, dat wil zeggen naar de classificatie die trilateraal voor de drie Waddenzeelanden (Nederland, Duitsland en Denemarken) is afgesproken (Petersen et al. 2014) om de monitoring in de drie landen goed bij elkaar te laten aansluiten. De VEGWAD-kaarten geven per vlak het percentage aan van de verschillende vegetatietypen. Voor de vertaling van SALT08 naar SALT97 en TMAP is het meest voorkomende vegetatietype gekozen. Deze methode heeft waarschijnlijk geen effect op de verdeling van de vegetatiezones maar kan wel effect hebben op het voorkomen van individuele vegetatietypes.

Naast deze rapportage wordt de analyse van de vegetatiekaarten ook gebruikt als input voor:

1) het trilaterale Quality Status Report (QSR) dat voor het laatst eind 2017 is verschenen (Esselink et al. 2017);

2) de jaarlijkse werkgroep en stuurgroep kwelderwerken, waaraan de eigenaren en beheerders van de kwelders langs de vastelandskust deelnemen;

3) andere rapportages in het kader van nationale en internationale verplichtingen, zoals de Habitatrichtlijn en de Kaderrichtlijn Water (KRW);

4) het bepalen van de effecten van beheermaatregelen, zoals veranderingen in damonderhoud, drainage en beweiding;

5) als referentie in projecten zoals de Slibmotor (Baptist et al. 2019b), kwelderontwikkeling bij Delfzijl (Marconi), en de aanleg van een klutenplas in de Dollard.

\subsection{Meetvakken (kwelderwerken)}

Vanaf 1960 is door RWS een monitoringsnetwerk aangelegd van 25 meetvakken verdeeld over de Friese en Groninger kwelderwerken (figuur 2.1, bijlage 2). Elk meetvak bestaat uit een reeks van drie bezinkvelden, van dijk tot en met het wad in Friesland of vanaf boerenkwelder tot en met wad in delen van Groningen (figuur 2.2). Een bezinkveld is $400 \times 400 \mathrm{~m}$ groot en bestaat uit 16 pandjes (subvakken) van elk 100 x $100 \mathrm{~m}$. De rijzendammen, gronddammen en ontwatering zijn volgens een vast patroon aangelegd (op een enkele uitzondering na). De hoofduitwateringen bevinden zich elke $200 \mathrm{~m}$ loodrecht op de dijk, de dwarssloten elke $100 \mathrm{~m}$ evenwijdig aan de dijk (afwaterend op de hoofduitwatering) en de greppels elke $10 \mathrm{~m}$ (afwaterend in een dwarssloot). In de loop van de jaren hebben er op locaties met een geringe opslibbing aanpassingen plaatsgevonden, waarbij dan vooral een vakverkleining van het bezinkveld is toegepast naar $200 \times 200 \mathrm{~m}$ door het plaatsen van tussenen/of dwarsdammen. Elk meetvak beslaat ca. 50 ha (doorgaans 48 pandjes verdeeld over drie bezinkvelden). Op deze meetvakken wordt de vegetatie jaarlijks opgenomen en de maaiveldhoogte elke 3 jaar ingemeten. 
Vegetatie: van 1960 tot en met 2018 is jaarlijks per meetvak in elk pandje van ca. 1 ha het bedekkingspercentage van dertig kweldersoorten opgenomen. De eerste decennia gebeurde dit door RWS zelf en de laatste tien tot vijftien jaar door externe partijen. Tussen 2005 en 2008 is de opname beperkt tot een meting van het wad tot aan het eerste kwelderpandje waar de bedekking $100 \%$ was. Omdat de successie van de vegetatie in de kwelderpandjes onderbelicht bleef, zijn vanaf 2009 in twee van de vier transecten per meetvak weer alle pandjes van wad tot dijk (zomerpolder of boerenkwelder) opgenomen. De jaarlijkse opnamen worden omgezet in kweldergemeenschappen en kwelderzoneringen volgens de SALT97-classificatie.

Maaiveldhoogte: Oorspronkelijk werd de maaiveldhoogte in ieder meetvak eens in de vier jaar volgens een roulerend systeem gewaterpast door de meetploeg van RWS (bijlage 3). Metingen vonden plaats in transecten evenwijdig aan de kust, midden door elk pandje. Vanaf 2004 wordt een minder arbeidsintensieve methode toegepast (i.e. RTK-GPS); het werk wordt uitgevoerd door een externe partij. Vanaf 2013 is de frequentie van de metingen aangepast naar een driejarig roulerend meetprogramma. De hoogtemetingen worden uitgevoerd in raaien van $400 \mathrm{~m}$ evenwijdig aan de dijk, in het midden van elk 1 ha-pandje. Het aantal raaien dat per meetvak gemeten wordt verschilt omdat de kwelder niet overal even breed is en de afstand tussen dijk en wad daardoor verschilt. 

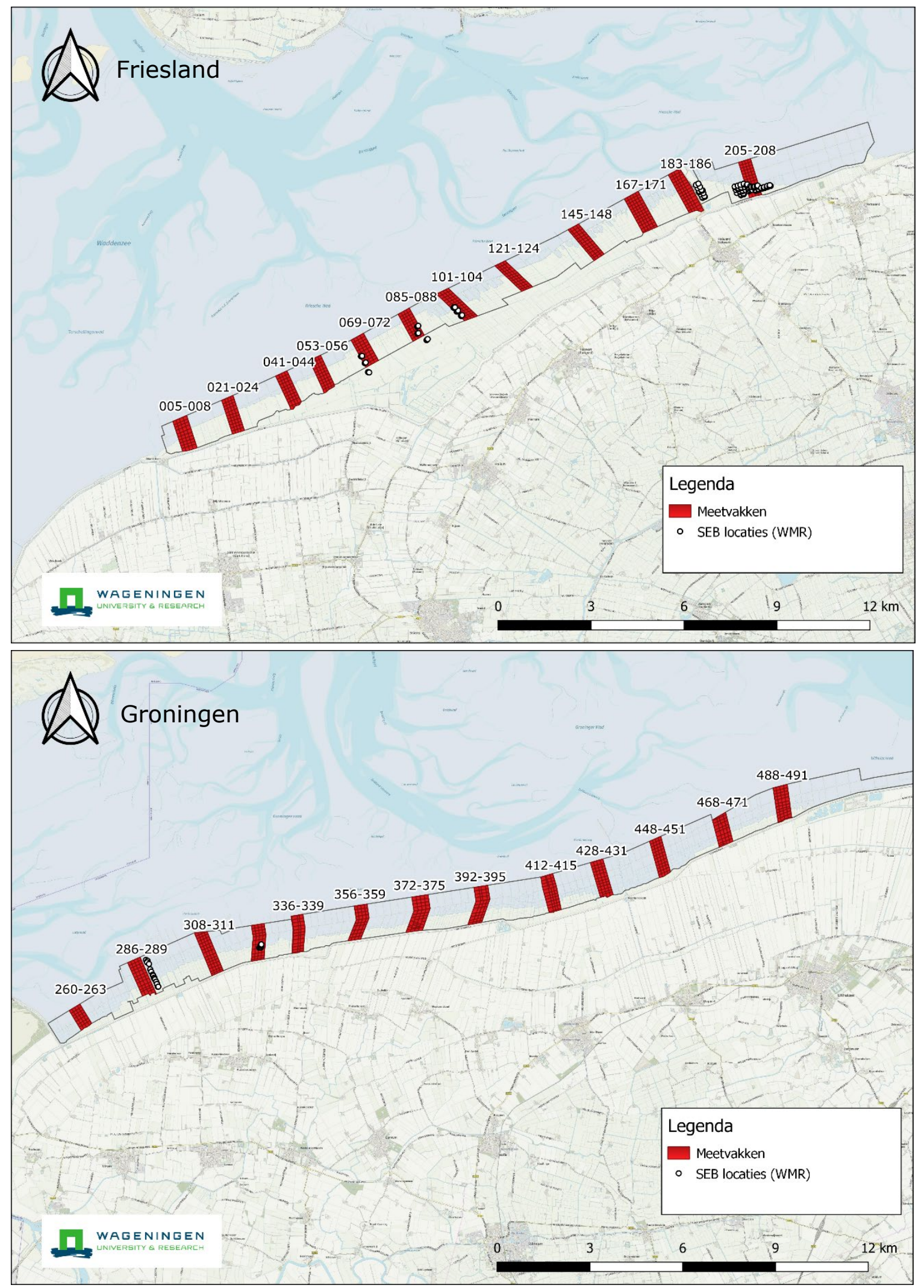

Figur 2.1 Ligging van de 25 meetvakken in de Friese en Groninger kwelderwerken. Voor de analyse van de meetvakken zijn de kwelderwerken onderverdeeld in drie deelgebieden in Friesland: Friesland-West (001062), Friesland-Midden (063-186) en Friesland-Oost (187-249), en drie deelgebieden in Groningen: Groningen-West (251-331), Groningen-Midden (332-401) en Groningen-Oost (402-516). Het Wageningse SEB-meetnet is hier met zwart/witte cirkels weergegeven. 


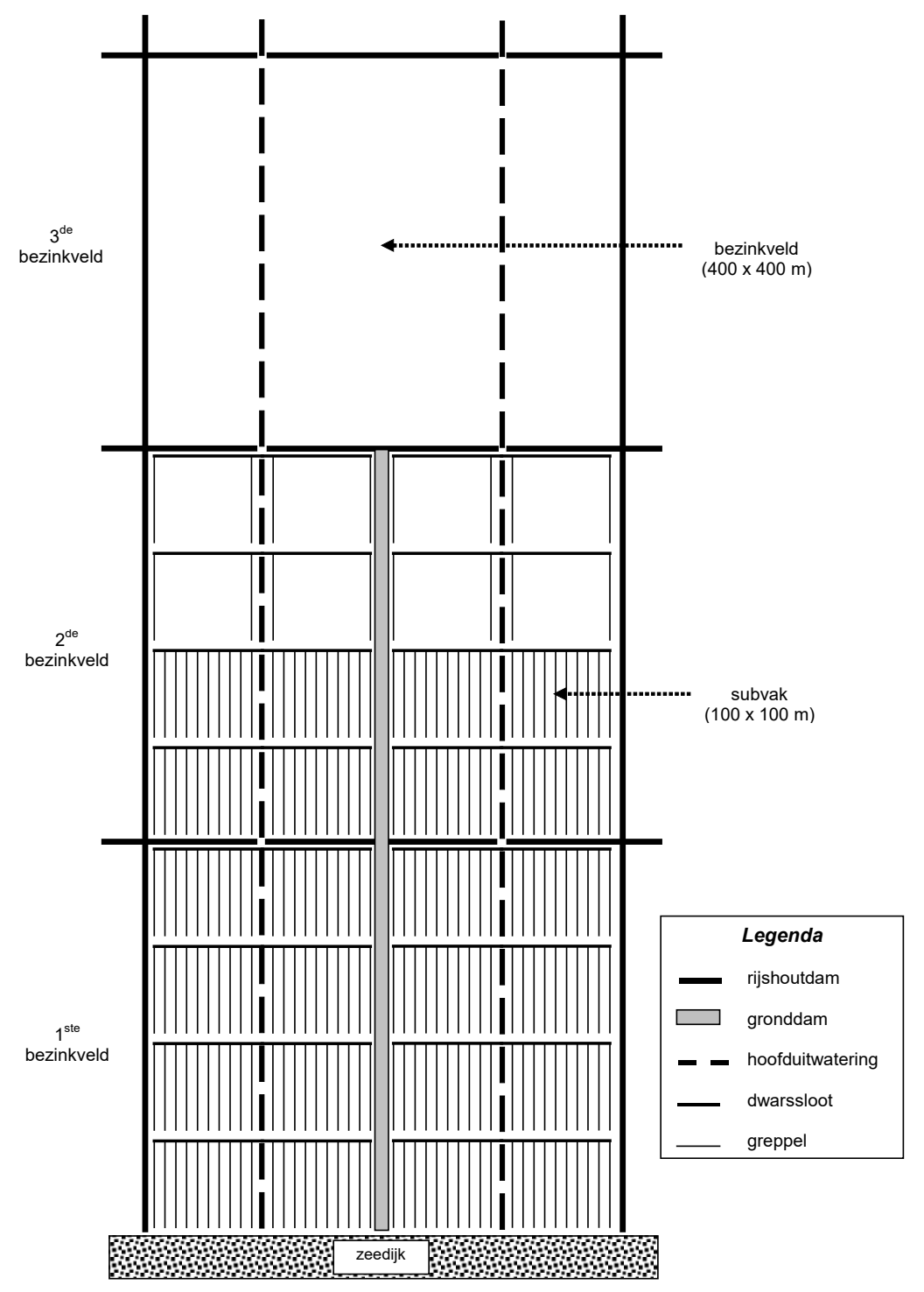

Figuur 2.2 Schematische indeling van één reeks bezinkvelden, van de zeedijk (onder) naar het wad (boven) (Kamps 1956, Dijkema et al. 2001). De totale huidige Friese en Groninger kwelderwerken bestaan uit ruim honderd soortgelijke eenheden.

\subsection{Wageningse SEB-meetnet langs de Friese en Groninger kust}

SEB staat voor Sedimentatie-Erosie-Balk. Deze balk wordt gebruikt om de opslibbing van het maaiveld te meten. Ieder SEB-meetpunt gaat tevens gepaard met een permanent kwadrant (PQ, $2 \times 2 \mathrm{~m}$ ) waarin de vegetatie wordt gemonitord (figuur 2.3). Inmiddels is er een uitgebreide set van SEBmeetpunten (figuur 2.3 en tabel 2.1) bestaande uit 136 meetpunten, geclusterd op vier locaties in de Groninger en Friese vastelandskwelders: Noord-Friesland Buitendijks, Holwerd, Julianapolder en Negenboerenpolder. De SEB-meetpunten liggen verdeeld in verschillende vegetatiezones in begraasde en niet-begraasde kwelderdelen. 


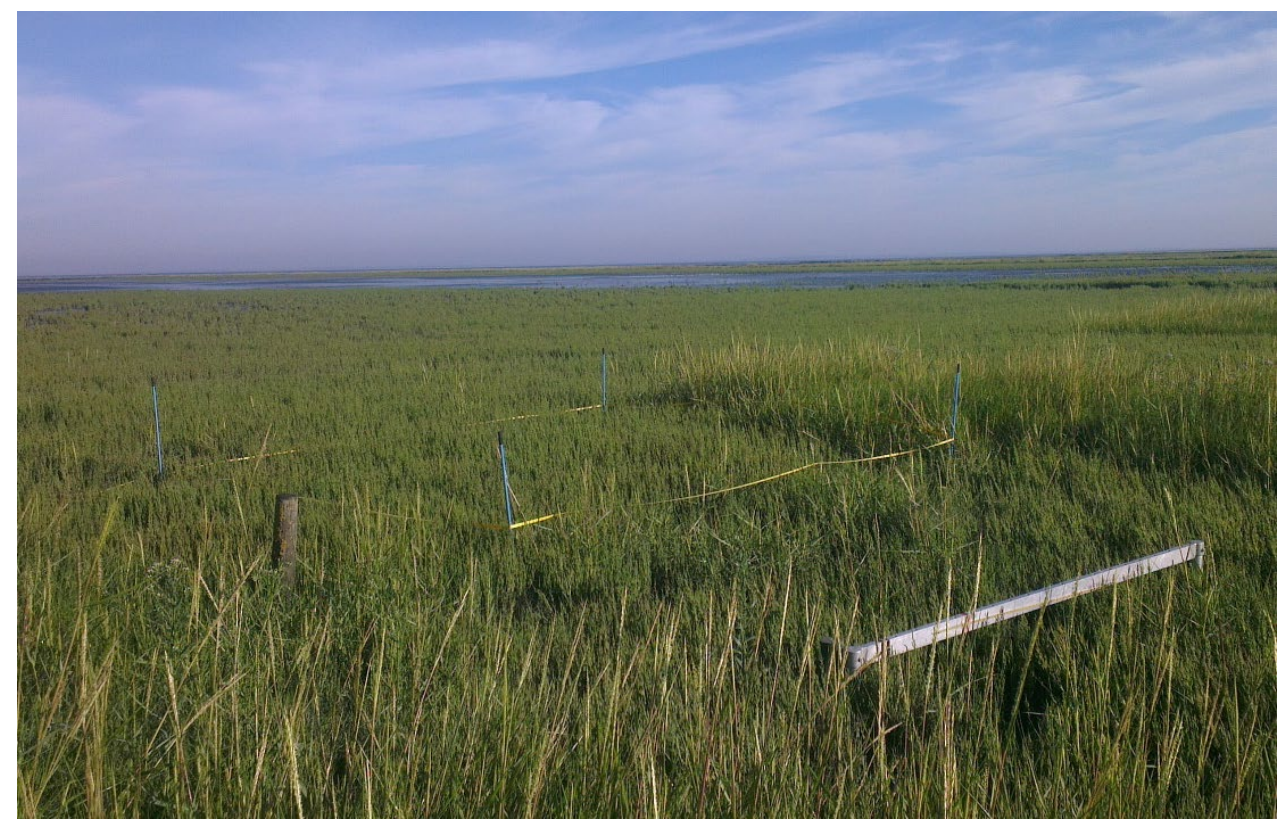

Figuur 2.3 Sedimentatie-Erosie-Balk (SEB) met voorliggend PQ waar de vegetatieopname jaarlijks wordt uitgevoerd (foto: Kelly Elschot, pionierzone Noord-Friesland Buitendijks).

Per SEB-meetpunt worden jaarlijks de volgende metingen verricht:

- $\quad$ Opslibbing met de Sedimentatie-Erosie-Balk (SEB-metingen; figuur 2.3) op alle 136 meetpunten in zowel het voorjaar (maart) als het najaar (augustus/september).

- Vegetatie-opnames in de PQ's volgens vaste bedekkingsschalen gebruikelijk voor vegetatieopnames (de decimale schaal van Londo of Tansley) in het najaar (augustus/september).

Voor ieder SEB-meetpunt zijn twee palen permanent in de bodem aangebracht en waterpas gesteld (Nolte et al. 2013a). Van elke paal is de hoogte ten opzichte van NAP ingemeten. Bij iedere meting wordt een 2 m lange aluminiumbalk met 17 gaten op de palen geplaatst. Vervolgens wordt van elk van deze 17 punten de afstand tussen balk en maaiveld bepaald (met een nauwkeurigheid van enkele $\mathrm{mm}$ ). Door de SEB-meting te vergelijken met de vorige meting kan bepaald worden of er in de tussenliggende periode een netto stijging (opslibbing) of daling (erosie en inklink) van het maaiveld heeft plaatsgevonden. Dit kan gerelateerd worden aan factoren zoals vegetatiehoogte, beheer, inundatiefrequentie en zeespiegelstijging.

Tabel 2.1 Overzicht van de locaties, aantallen en duur van de lange-termijnmeetreeksen van het Wageningse SEB-meetnet.

\begin{tabular}{lll} 
Locatie & Aantal PQ's & Tijdreeks \\
Noord-Friesland Buitendijks (Friesland) & 27 & $2002-\mathrm{nu}$ \\
\hline Holwerd (Friesland) & 74 & $1998-\mathrm{nu}$ \\
\hline Negenboerenpolder (Groningen) & 15 & $1994-\mathrm{nu}$ \\
\hline Julianapolder (Groningen) & 20 & $1998-\mathrm{nu}$ \\
\hline
\end{tabular}

In ieder PQ worden over een oppervlak van $4 \mathrm{~m}^{2}$ alle plantensoorten genoteerd, de vegetatiehoogte gemeten en de bedekking per plantensoort geschat. In Noord-Friesland Buitendijks, Julianapolder en Negenboerenpolder wordt de schaal van Londo (1976) gehanteerd om de vegetatiebedekking te schatten, en in Holwerd de Tansley-schaal. De vegetatiebedekking kan per plantensoort worden geanalyseerd of omgezet in vegetatietype en vegetatiezoneringen.

De metingen leveren dus gegevens over de opslibbing, maaiveldhoogteverandering (ten opzichte van NAP of GHW) en vegetatieontwikkeling op diverse locaties langs de Friese en Groninger kust.

Daarnaast wordt voor ieder SEB-meetpunt ook de afstand tot de kreek, beweidingsintensiteit, soort vee (i.e. koeien, paarden of schapen) en ontwatering genoteerd. Met deze metingen kunnen in detail 
de processen bestudeerd worden die de ontwikkeling van de Natura 2000-habitattypen in de kwelderwerken beïnvloeden: zilte pionierbegroeiingen (zeekraal) (H1310A), slijkgrasvelden (H1320) en schorren en zilte graslanden buitendijks (H1330A). Hiermee kunnen de effecten van zeespiegelstijging en beheer worden beoordeeld en mogelijke veranderingen in biodiversiteit gemonitord.

De SEB-metingen zijn puntmetingen, dus niet geschikt voor vlakdekkende trends. Maar door ze in verschillende kwelderzones te plaatsen kunnen binnen een kwelder veranderingen in maaiveldhoogte per zonering of vegetatietype worden bepaald.

\subsection{Beheer en onderhoud}

De kwelders op de Waddeneilanden zijn min of meer natuurlijk gevormd onder invloed van stuifdijken op de eilanden. De kwelders langs de vastelandskust daarentegen komen voort uit de vroegere landaanwinningswerken en zijn daarmee half-natuurlijke landschappen. Voor kwelderbehoud is onderhoud nodig van een groot deel van de rijzendammen. Een deel wordt ook niet langer onderhouden, zoals de buitenste dammen gelegen op het wad langs de vastelandskust en de dammen bij de kwelder bij Wierum en de Dollardkwelders. In de Dollard worden ze al sinds de jaren vijftig van de vorige eeuw niet meer onderhouden, daar is nu sprake van een geleidelijk eroderende kwelderrand (Esselink et al. 2011).

\subsubsection{Onderhoud rijzendammen}

De afgelopen dertig jaar is er veel aandacht geweest voor het optimaal onderhouden van de rijzendammen ter bescherming van de kwelders en de pionierzone. In de tijd zijn er verschillende veranderingen doorgevoerd (zie ook Dijkema et al. 2013, Van Duin et al. 2016):

- Vanaf 1989 werd de eerste prioriteit het voorkomen van de zogenaamde achterloopsheid (= uitspoeling of onderspoeling van dammen door waterlopen) van de dammen. Om die tegen te gaan zijn twee maatregelen genomen: 1 ) er zijn extra tussendammen geplaatst waardoor in delen van Friesland en Groningen de hoofddammen zijn verkleind naar 200 m (i.p.v. 400 m), en 2) de buitenste bezinkvelden zijn verlaten.

- De damhoogte is aangepast vanwege de stijging in GHW en de bodemdaling door gaswinning. Vanaf 2000 wordt duurzaam vulhout toegepast.

- $\quad$ In Friesland is in 2006 het damonderhoud tussen Zwarte Haan en Nieuwe Bildtzijl gestopt vanwege de snelle opslibbing.

- In Groningen-Oost is de opslibbing verhoogd door een damrenovatie in de periode 1994-1998 waarbij tussendammen en een $10 \mathrm{~km}$ lange dwarsdam zijn geplaatst. Dit is deels uitgevoerd omdat hier bodemdaling door gaswinning plaatsvindt.

- In 2010 heeft de stuurgroep kwelderwerken een aantal belangrijke veranderingen aangenomen: de rijzendammen evenwijdig aan de kust worden afhankelijk van de veranderingen in de arealen van kwelder- en pionierzone na 2000 flexibel onderhouden; dammen loodrecht op de kust die minder dan $25 \mathrm{~cm}$ boven het maaiveld uitsteken, worden niet langer onderhouden; en oostelijk van Holwerd worden sinds 2011 helemaal geen dammen meer bijgevuld.

- Achterloopsheid van rijzendammen kan tot erosie leiden, wat blijvend wordt gemonitord, geïnventariseerd en desgewenst gerepareerd.

Dankzij de wijzigingen in het onderhoud van de rijzendammen is het oppervlak van de buitenste bezinkvelden op het wad met ca. 2.000 ha verminderd. De totale damlengte in onderhoud is teruggebracht van $250 \mathrm{~km}$ in 1998 naar $110 \mathrm{~km}$ in 2018.

Het huidige damonderhoud vindt plaats in een driejarige cyclus gebaseerd op prestatie-eisen (bijlage 3). Omdat de kwelders in Friesland nog steeds geleidelijk aangroeien, komt de pionierzone in de knel tussen de groeiende kwelderrand en de buitenste nog in onderhoud zijnde dammen (Van Duin et al. 2019). Door erosie en aangroei van de kwelder toe te staan, wordt opnieuw ruimte gecreëerd voor de 
pionierzone. Daarom is er een pilot ontworpen waarin de buitenste dammen van het tweede bezinkveld evenwijdig aan de kust uit het onderhoud zijn genomen.

Het gaat hierbij om:

- $\quad$ Friesland, loslaten dammenonderhoud in 2021 (dam 63-97).

- Groningen, loslaten dammenonderhoud in 2017 (dam 424-434).

Deze pilots zullen de komende jaren nauwlettend gevolgd worden in de werkgroep en stuurgroep kwelderwerken.

\subsubsection{Grondwerk}

In de eilandkwelders is er geen of nauwelijks sprake van enig grondwerk. In de vastelandskwelders was het gebruikelijk om een sterk vertakt drainagesysteem van greppels, zij- en hoofduitwateringen te graven en te onderhouden (Esselink et al. 2017). Zo werd de vestiging van planten bevorderd en de successie gestimuleerd. Uit hoogtegegevens van Duitse eilandkwelders blijkt dat er geen effect is van grondwerk op de opslibbing (Michaelis 2008). De verwachting is dat het wel een effect heeft op de vegetatie doordat:

- de vegetatiezones zich op een lager niveau konden vestigen,

- minder waterplassen en kale plekken,

- $\quad$ en de successie versneld plaatsvindt (Dijkema et al. 2013).

Sinds de jaren negentig van de vorige eeuw is het onderhoud aan sloten, greppels en gronddammen in de kwelders sterk verminderd en in grote delen volledig gestopt (Esselink et al. 2017). Hiermee wordt een toename in natuurlijkheid beoogd, wat een belangrijk trilateraal doel is (Wadden Sea Plan Target). Het grondwerk in de Friese en Groninger kwelderwerken is teruggebracht van $970.000 \mathrm{~m}^{3}$ naar $7.000 \mathrm{~m}^{3}$ in 2000 (Dijkema et al. 2013). In de Dollard worden de greppels in de noordwestelijke particuliere kwelders nog wel onderhouden, maar in de zuidoostelijke kwelders, beheerd door Stichting Het Groninger Landschap, is dit gestopt.

\subsubsection{Beweiding}

Vegetatiesuccessie binnen kwelders is een autonoom proces (Olff et al. 1997). Door geleidelijke ophoging van het maaiveld en de daarmee gepaard gaande afname in inundatie treedt successie van de vegetatie op. Doorgaans eindigt dit proces in een climaxvegetatie van zeekweek (Elytrigia atherica) met een lagere plantendiversiteit (Veeneklaas et al. 2013, Wanner et al. 2014). Begrazing door kleine grazers, zoals hazen en ganzen, kan de successie vertragen (van der Wal et al. 2000), terwijl beweiding door vee de successie kan omkeren (Kuijper et al. 2008). Dit wordt ook wel verjonging van de vegetatie genoemd.

Een groot deel van de kwelders langs de vastelandskust (de kwelderwerken en de Dollardkwelders) worden begraasd door runderen, paarden en/of schapen (Esselink et al. 2017, Nolte et al. 2017). De eilandkwelders zijn voor bijna $80 \%$ onbegraasd, waarbij veelal alleen de oudste, meest westelijke kwelders wel extensief begraasd worden (Esselink et al. 2017). De effecten van de beweiding variëren met de intensiteit ervan en het type grazer. De effecten van kleine grazers (hazen en ganzen) op de opslibbing is verwaarloosbaar, terwijl beweiding met vee een negatief effect heeft op de ophoging van kwelders (Elschot et al. 2013). Intensieve beweiding met paarden kan een ongunstig effect hebben op bloeiende planten, muizen en broedvogels door vertrapping (Esselink et al. 2016, van Klink et al. 2016). Voor de meest gunstige effecten op de algehele biodiversiteit wordt een afwisseling in beweidingsintensiteit aanbevolen, gecombineerd met permanent onbeweide kwelderdelen (Esselink et al. 2016, van Klink et al. 2016).

Binnen de kwelderwerken varieert de beweidingsintensiteit van jaar op jaar (figuur 2.4). In Groningen nam de beweiding vanaf 2001 sterk af, tot in de periode 2011-2013 het Groninger Kwelderherstelplan werd uitgevoerd. Door ophoging van gronddammen en dijkhekken, gecombineerd met het verondiepen van een deel van het ontwateringssysteem, kan het vee makkelijker hogere kwelderdelen bereiken tijdens overstromingen. Daarnaast werd het door het aanleggen van bruggen over de hoofdleidingen mogelijk gemaakt om grotere beweidingseenheden te vormen en vee makkelijker 

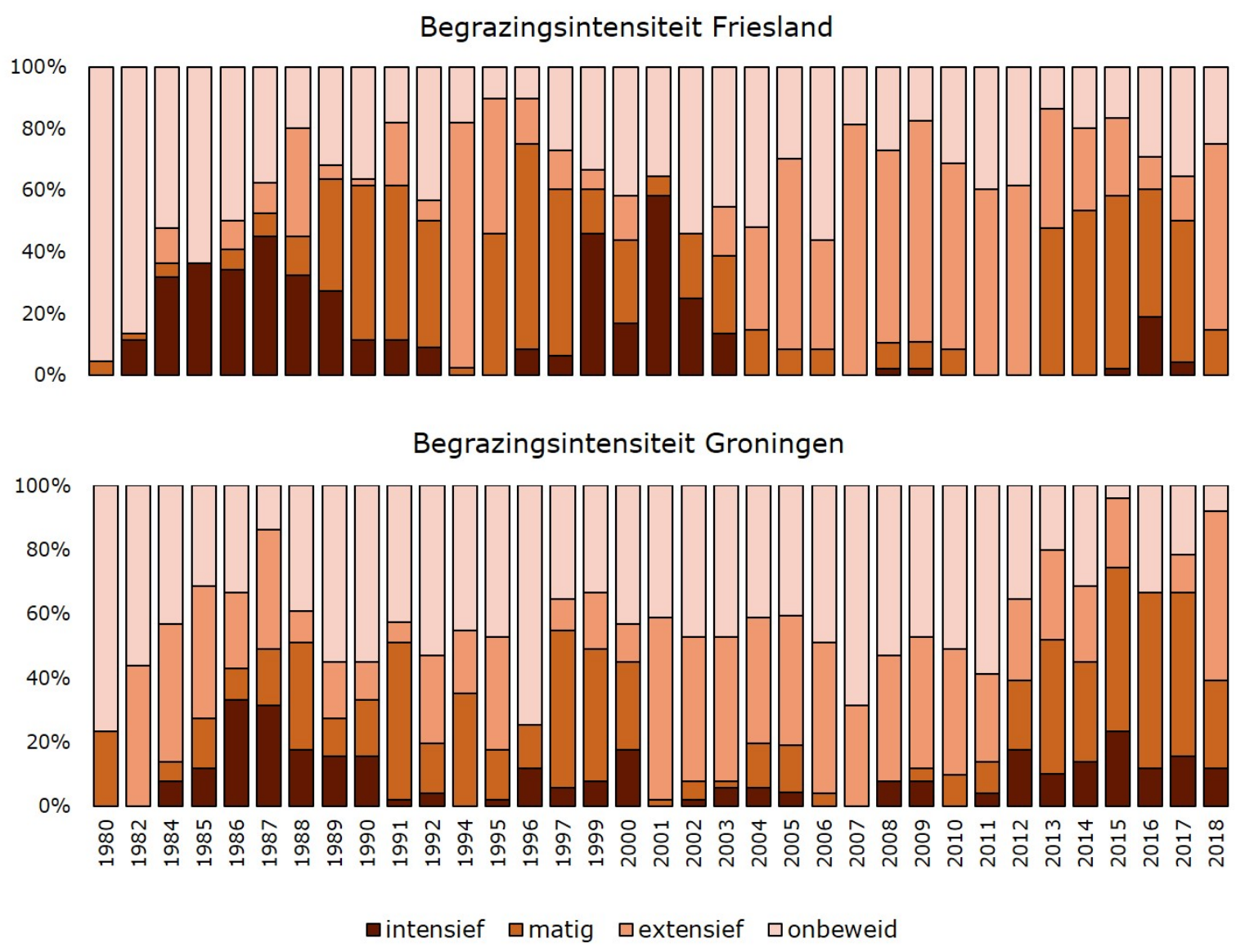

Figuur 2.4 Beweidingsintensiteit in de Friese en Groninger kwelderwerken (bron data: meetvakken). De intensiteit is weergegeven voor intensief, matig, extensief en niet-beweid voor alle kwelders binnen de meetvakken. Slechts enkele panden zijn nooit beweid geweest in de periode 1980-nu, en meestal varieert de intensiteit van jaar op jaar. 


\section{Vegetatieontwikkelingen}

\subsection{Kwelderareaal Waddenzee (VEGWAD)}

De afgelopen decennia (1999 - 2017) is er een toename van het kwelderareaal in de Waddenzee (figuur 3.1). Dit komt door uitbreiding van de kwelders op de Waddeneilanden richting het oosten, door aangroei van de vastelandskwelders en door enkele ontpolderingsprojecten langs de Friese kust. In vergelijking met enkele eeuwen geleden is er wel veel verloren gegaan. Het areaal aan kwelders bereikte in de twintigste eeuw een dieptepunt, maar neemt sindsdien geleidelijk weer toe. In de periode 1600 - 1800 was er een zeer groot oppervlak aan vastelandskwelders. Deze kwelders zijn in de loop van de tijd ingepolderd en in gebruik genomen als landbouwgebied (Dijkema 1987b). In deze periode was het kwelderareaal op de westelijke Waddeneilanden ook veel groter. Deze zijn ontstaan na het ontginnen van het wad tussen Texel en Eierland en na de aanleg van een zanddijk tussen de eilanden Callantsoog en Huisduinen. Beide gebieden zijn ingepolderd in de negentiende eeuw, waardoor het areaal weer sterk afnam (Dijkema 1987b). Door een kleiner getijverschil en het inpolderen van de hoger gelegen intergetijdeplaten zijn er minder mogelijkheden geweest voor de ontwikkeling van nieuwe kwelders in het westelijke gedeelte van de Waddenzee. Op de oostelijke Waddeneilanden zijn de kwelders toegenomen (figuur 3.1) door geleidelijke uitbreiding van de eilandstaarten.

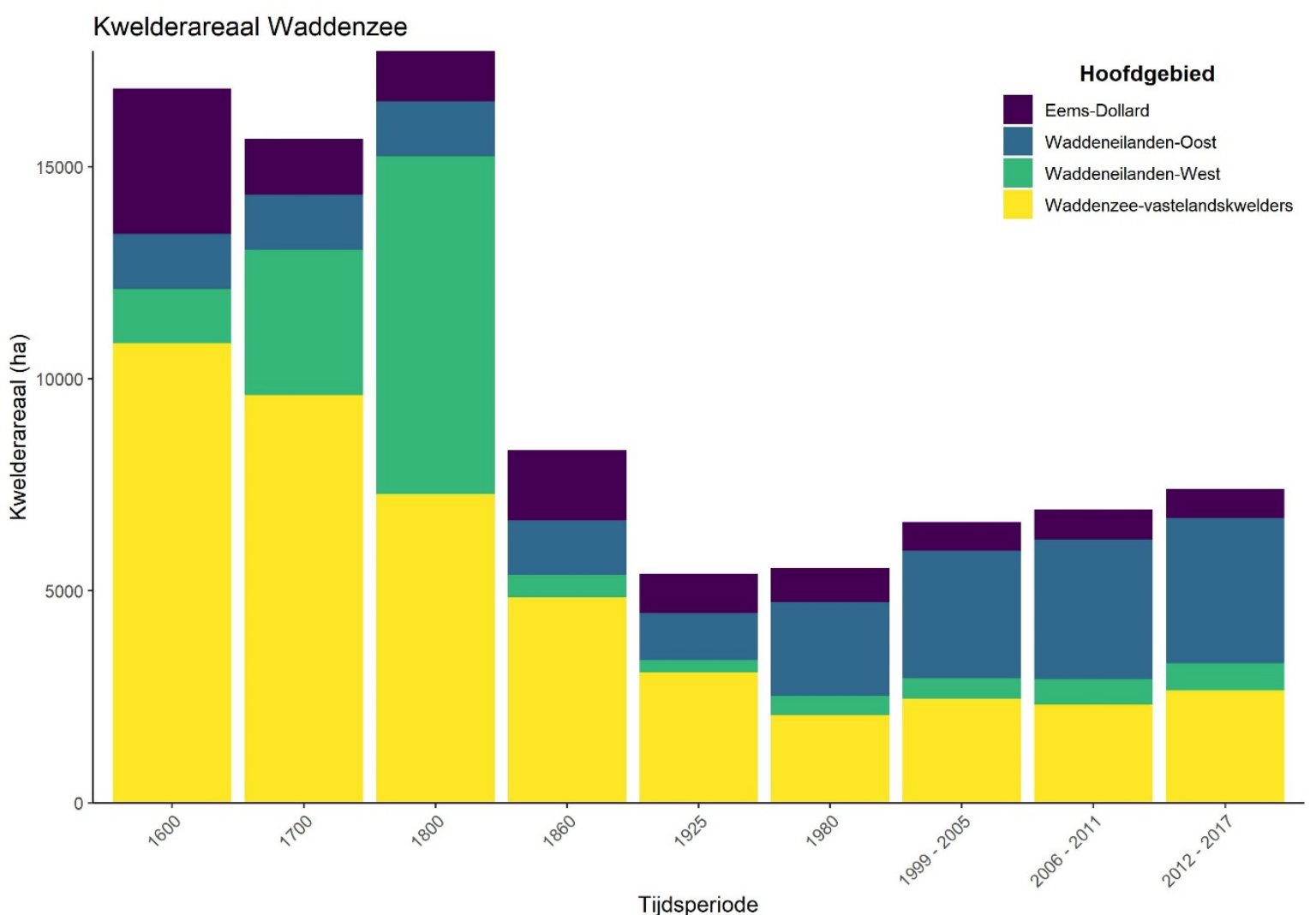

Figuur 3.1 Het kwelderareaal in de Waddenzee in de periode 1600 - 2017 (bron data: periode 1600 t/m 1980 uit Dijkema et al. 1987b, periode 1999-2017 gebaseerd op de VEGWAD-karteringen). Het totale kwelderareaal is weergegeven exclusief de pionierzone, aangezien het areaal daarvan niet bepaald kon worden uit de oude kaarten (Dijkema 1987b). Kwelders verloren gegaan door het afsluiten van de Zuiderzee, en zomerpolders zijn niet meegenomen.

Tussen de zestiende en begin twintigste eeuw is door inpolderingen het kwelderareaal in de Dollard geleidelijk afgenomen (Esselink 2000). Het huidige kwelderareaal is ca. 760 ha (Esselink et al. 2011), 
dat geleidelijk afneemt door erosie van de kwelderrand sinds gestopt is met de landaanwinningswerken in 1954 (Esselink et al. 2011, 2019b). Afslag van de kwelderrand varieert per locatie en in de tijd, maar in de periode 1981- 2009 was dit gemiddeld tussen de 1 en 2 m per jaar. De afslag wordt geweten aan een te sterke golfslag door zeespiegelstijging en wroetende grauwe ganzen (Anser anser) foeragerend op heen (Bolboschoenus maritimus) op de kwelderrand (Esselink et al. 2011).

De verdeling van de verschillende vegetatietypes varieert per deelgebied. Zo is op de vastelandskwelders het areaal aan pioniervegetatie het grootst en in de afgelopen twintig jaar toegenomen (figuur 3.2). Maar het totaal oppervlak aan pionierzone grenzend aan het wad is in de afgelopen twaalf jaar vrijwel gelijk gebleven met ongeveer 1.000 ha (tabel 3.1; zie sectie 3.2.1). De gevonden toename aan pionierzone gebaseerd op de TMAP-classificatie komt door een toename aan pioniervegetatie met lage kweldersoorten binnen de lage kwelderzone. Dit vegetatietype wordt in de SALT97-classificatie bij de lage kwelder gerekend (tabel 3.1), terwijl deze in de TMAP-classificatie bij de pioniervegetatie wordt gerekend (figuur 3.2). Dit vegetatietype is een plantengemeenschap met klein schorrenkruid, zilte schijnspurrie (Spergularia salina) en/of stomp kweldergras (Puccinellia distans). Dit type is in Friesland-West en Friesland-Midden toegenomen van 50 ha in 2002 naar 500 ha in 2014 (tabel 3.1). Dit kan op twee manieren verklaard worden. Deels is het een gevolg van successie van pioniervegetatie naar lage kwelder, waardoor er een mix van soorten van de pionierzone en lage kwelder voorkomt. Een tweede oorzaak is de vernatting van de kwelder door het stoppen met greppelen in combinatie met vertrapping van de zachte bodem door vee. De ruim $10 \mathrm{~km}^{2}$ aan zoete graslanden bevinden zich vooral in de zomerpolders (figuur 3.2). De afname in zoete graslanden komt door de ontpoldering van twee zomerpolders in Friesland: 135 ha bij Noorderleeg in 2001 en 45 ha bij Bildtpollen in 2009.

Op de Waddeneilanden vindt vooral op het westelijke deel van Terschelling (bij de Noordsvaarder) nog uitbreiding van het kwelderareaal plaats. In de oostelijke delen van de Waddeneilanden vond ook uitbreiding van de kwelder plaats, maar die is in de laatste jaren gestabiliseerd (figuur 3.2). De climaxvegetatie van hoge kwelder met zeekweek neemt toe op de oostelijke Waddeneilanden, wat het gevolg is van autonome successie in onbeweide kwelders (Veeneklaas et al. 2013, Wanner et al. 2014). In de Dollard zien we vooral een afname aan brakke vegetatie en hoge kweldervegetatie met zeekweek. Onder invloed van beweiding en vernatting door een afgenomen drainage is dit areaal grotendeels veranderd in lage kwelder (figuur 3.2).

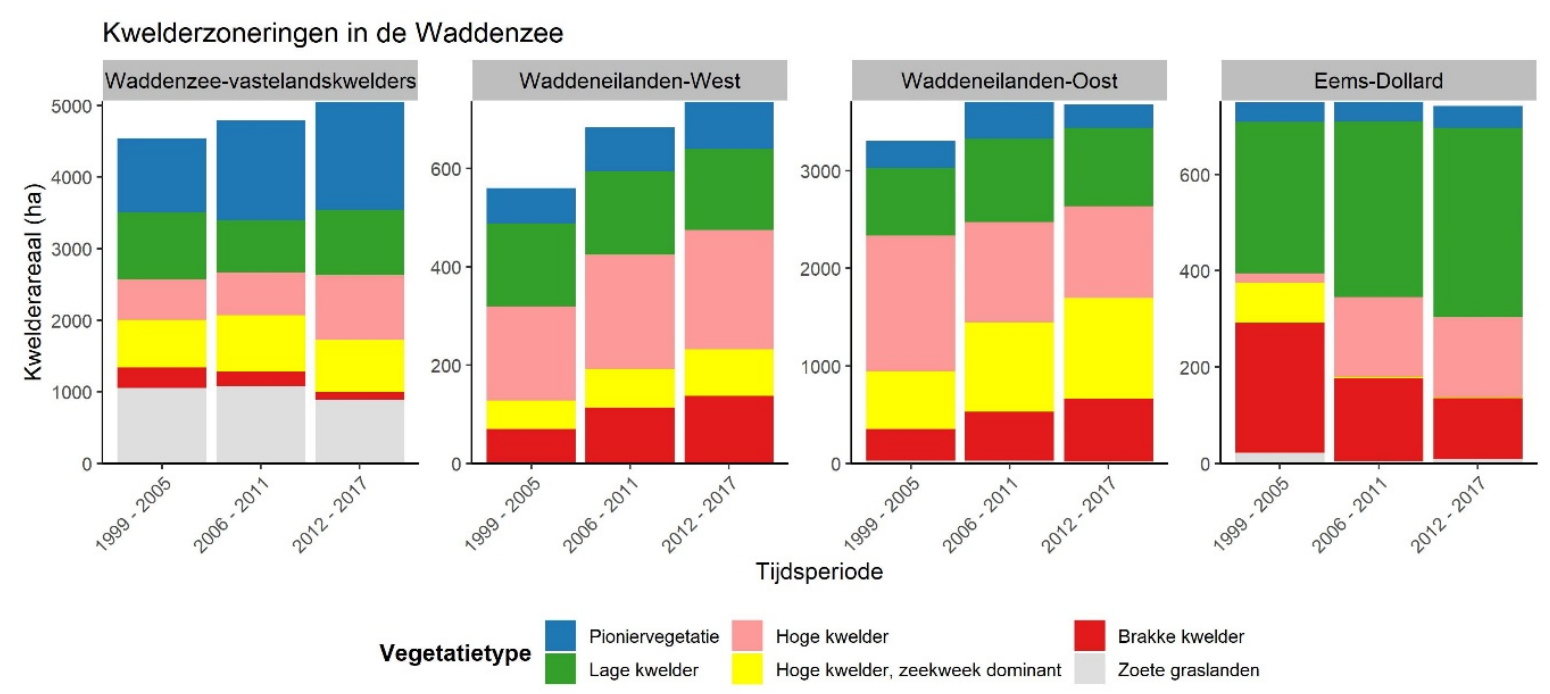

Figuur 3.2 Overzicht van het voorkomen van de verschillende vegetatietypes (in hectares) voor de verschillende deelgebieden in de Waddenzee, gebaseerd op de vegetatieclassificatie TMAP (Petersen et al. 2014). Voor de Waddenzee-vastelandskwelders is dit inclusief: de vastelandskwelders in NoordHolland, de sinds 2014 nieuw gekarteerde kwelder bij Westhoek (28 ha) de boerenkwelders en zomerpolders. 
Tabel 3.1 Arealen van de vegetatiezones in de Friese en Groninger kwelderwerken op basis van de VEGWAD-karteringen in de SALT97-classificatie. Dit is inclusief de boerenkwelders en de ontpolderde gebieden (135 ha bij Noorderleeg en 45 ha bij Bildtpollen), exclusief de zomerpolders.

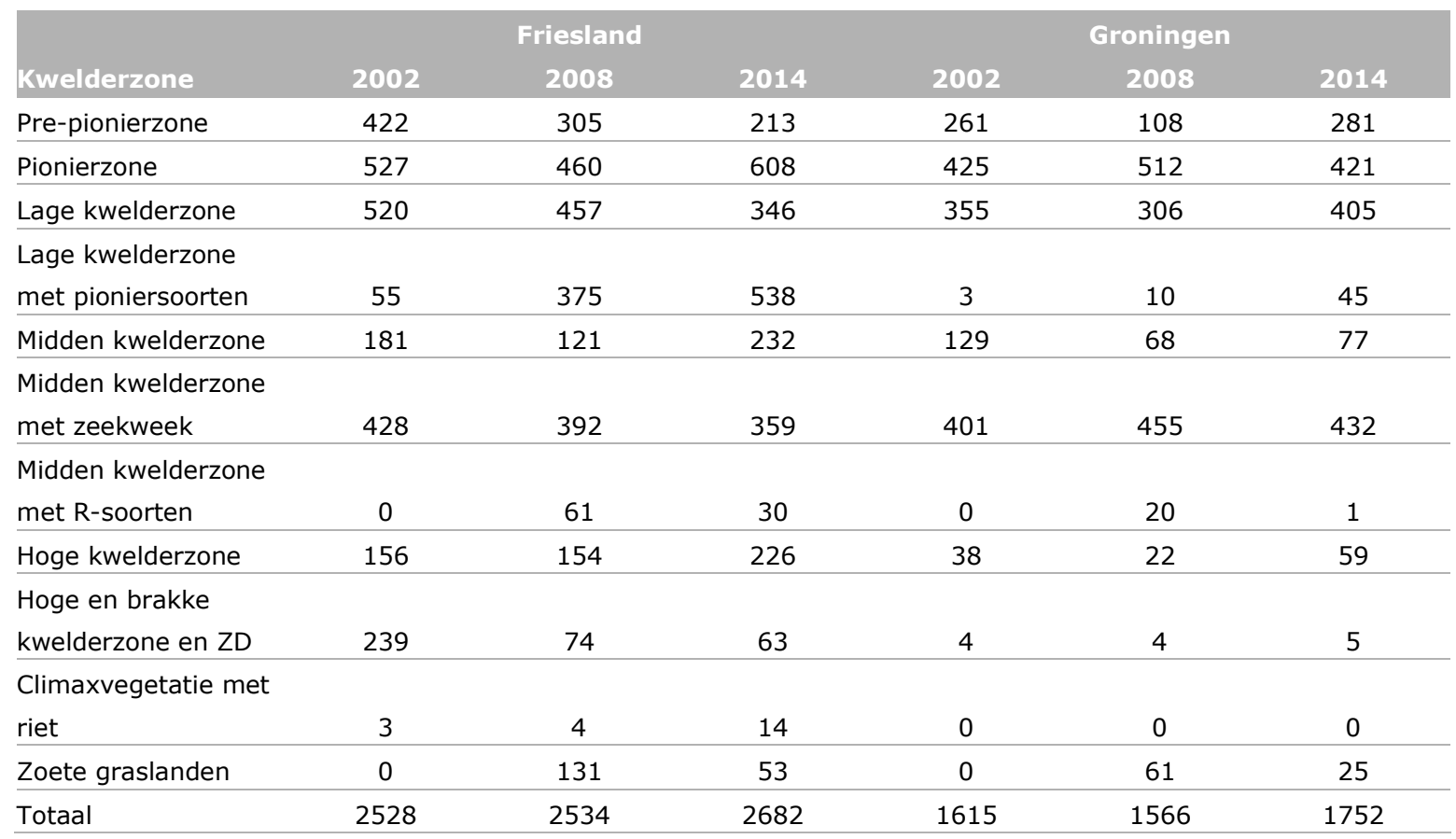

\subsection{Vegetatieontwikkeling kwelderwerken 1960 - 2018}

\subsubsection{Toetsing aan de functie-eisen van RWS}

In deze rapportage worden drie functie-eisen getoetst om te bepalen of veranderingen nodig zijn in het beheer en onderhoud van de kwelderwerken. De vierde en laatste eis wordt niet in deze rapportage getoetst omdat eerst nader overleg nodig is met de beheerders en gebruikers voordat hierover gerapporteerd wordt.

1) Het totale areaal van de jonge kwelder in Friesland en Groningen bedraagt minstens 1.250 ha (gemiddeld over de laatste vijf jaren). Hiervan ligt minstens een derde (420 ha) in elke provincie.

Gebaseerd op de VEGWAD-kartering uit 2014 is er 4.334 ha aan kwelders binnen de kwelderwerken, waarvan 2.682 ha in Friesland en 1.752 ha in Groningen (tabel 3.1). Bovendien is binnen de meetvakken in de laatste vijf jaar (periode 2013-2018), het kwelderareaal in Friesland toegenomen en in Groningen stabiel gebleven (figuur 3.3). Daarmee wordt ruimschoots voldaan aan functie-eis 1.

2) De actuele kweldergrens mag nergens verder teruggaan dan tot de oorspronkelijke grens particulier eigendom (de "oude" kwelder, ook wel de "afgepaalde" kweldergrens").

Aan deze functie-eis is getoetst op vergelijkbare wijze als in Dijkema et al. (2013): de oude / afgepaalde kweldergrens is over de nieuwste VEGWAD-kartering uit 2014 gelegd. Vervolgens is bepaald waar de vegetatiegrens verder is teruggetrokken dan deze grens. Alleen in Groningen zijn er drie locaties waar de vegetatiegrens lokaal verder terug is getrokken dan de afgepaalde kweldergrens (zie ook bijlage 4):

- $\quad$ Langs de Westpolder (meetvakken 260-271), waar de vegetatiegrens op enkele locaties voorbij de oude kweldergrens ligt. Dit wordt ook al in vorige rapportages benoemd (Dijkema et al. 2013). Als maatregel is daar in 2000 damrenovatie en vakverkleining uitgevoerd om te proberen de opslibbing te stimuleren.

- Noordwest-hoek Linthorst-Homanpolder (meetvakken 349-355), waarbij de vegetatiegrens op enkele locaties voorbij de oude kweldergrens gaat. Deze locatie wordt 
ook al in een eerdere rapportage benoemd (Dijkema et al. 2013). Hier lag in 1960 en 1980 ook geen kwelder omdat de oude kweldergrens hier te optimistisch is getrokken en er in de jaren dertig van de vorige eeuw kleiputten zijn gegraven.

- Midden van Linthorst-Homanpolder (meetvakken 373-374), waar de vegetatiegrens op één locatie voorbij de afgepaalde kweldergrens gaat.

De conclusie is dat er langs het merendeel van de vastelandskust aan deze tweede functie-eis wordt voldaan, behalve de drie bovengenoemde locaties waar de vegetatiegrens verder is teruggetrokken dan de afgepaalde kweldergrens.

3) Minimaal 750 ha pionierzone met een vegetatiebedekking $>5 \%$ binnen de kwelderwerken, voor beide provincies samen.

Gebaseerd op de VEGWAD-kartering uit 2014 is er in totaal 1.020 ha aan pionierzone binnen de kwelderwerken (tabel 3.1), waarvan 608 ha in Friesland en 421 ha in Groningen. In de afgelopen vijf jaar (periode 2013 - 2018) is de pionierzone in Friesland iets afgenomen, terwijl die in de Groningen iets is toegenomen (figuur 3.3). Daarmee wordt voldaan aan functie-eis 3.

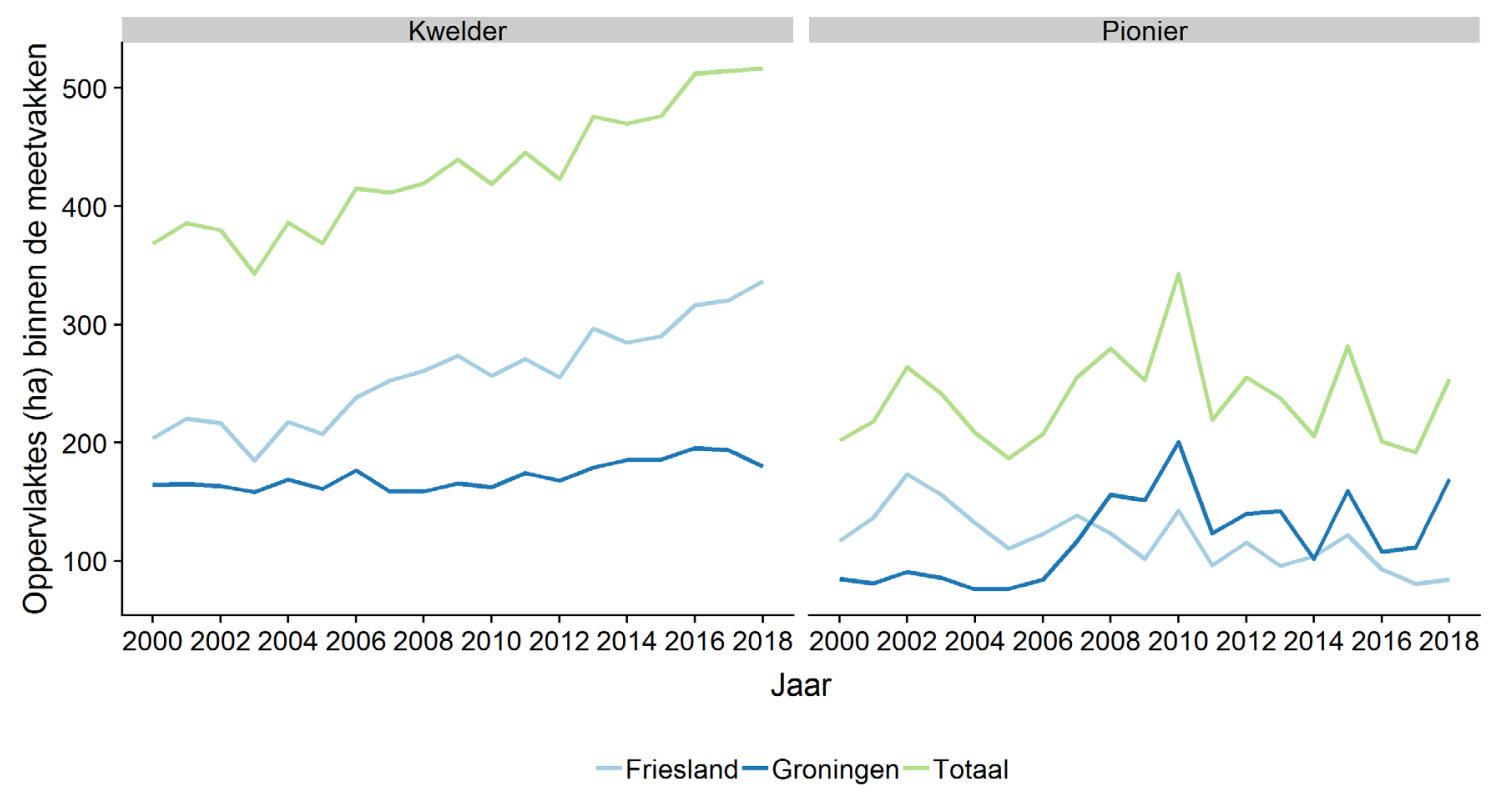

Figuur 3.3 Verandering in arealen van pionierzone en kwelderzone binnen de meetvakken in Friesland en Groningen. Kwelderzone en pionierzone zijn bepaald op basis van de SALT97-classificatie (meetvakken). Boerenpolders en zomerpolders zijn hier niet meegenomen. 


\subsubsection{Vegetatieontwikkeling kwelderwerken 1960 - 2018 (meetvakken)}

Langs de Friese kust is binnen de meetvakken sprake van een duidelijke toename van de kwelderzone en een geleidelijke afname van de pionierzone (figuren 3.3 en 3.4). Dit komt door een relatief snelle kwelderaanwas richting de buitenste nog in onderhoud zijnde rijzendammen (begin derde bezinkveld) waardoor er geen ruimte meer is voor de pionierzone en deze afneemt (figuur 3.4). Deze groei is ook te zien in de vegetatieontwikkeling in de individuele meetvakken in bijlage 5 (zie bijvoorbeeld meetvak 41-44 waar de pionierzone bijna volledig is verdwenen). In verhouding tot de deelgebieden FrieslandWest en Friesland-Midden beslaat Friesland-Oost een veel kleiner oppervlak. Ondanks dat de rijzendammen sinds 2011 niet langer worden onderhouden, is de kwelderzone stabiel en neemt de pionierzone de afgelopen jaren weer iets toe (zie ook bijlage 5, meetvak 205-208).

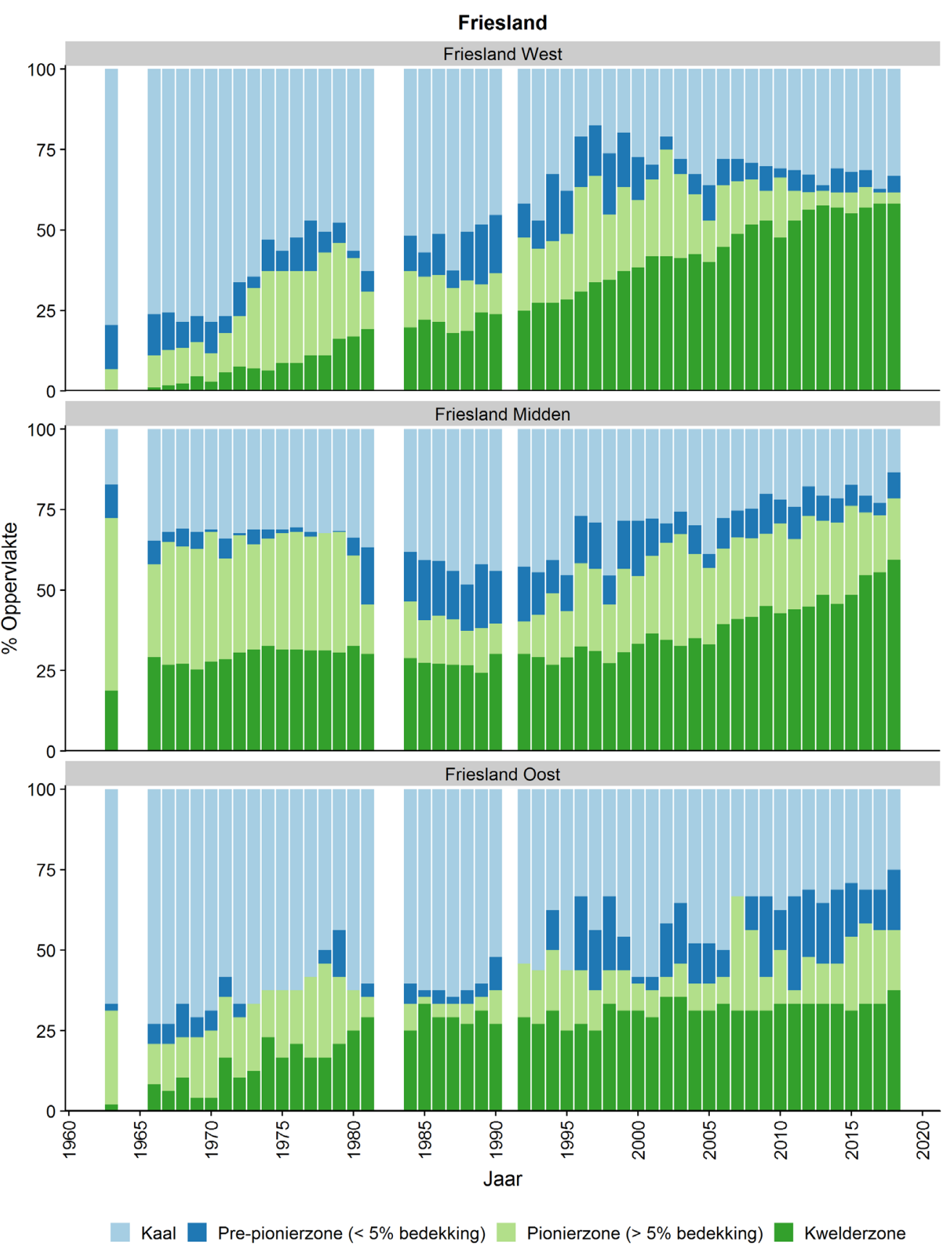

Figuur 3.4 Veranderingen in oppervlakte van kwelderzone, pionierzone, pre-pionierzone en kaal wad in de deelgebieden Friesland-West (001-062), Friesland-Midden (063-186) en Friesland-Oost (187249). Deze zijn berekend in percentages bedekking ten opzichte van het hele meetvak. Kwelderzone en pionierzone zijn bepaald op basis van de SALT97-classificatie. Witte kolommen zijn missende gegevens. 


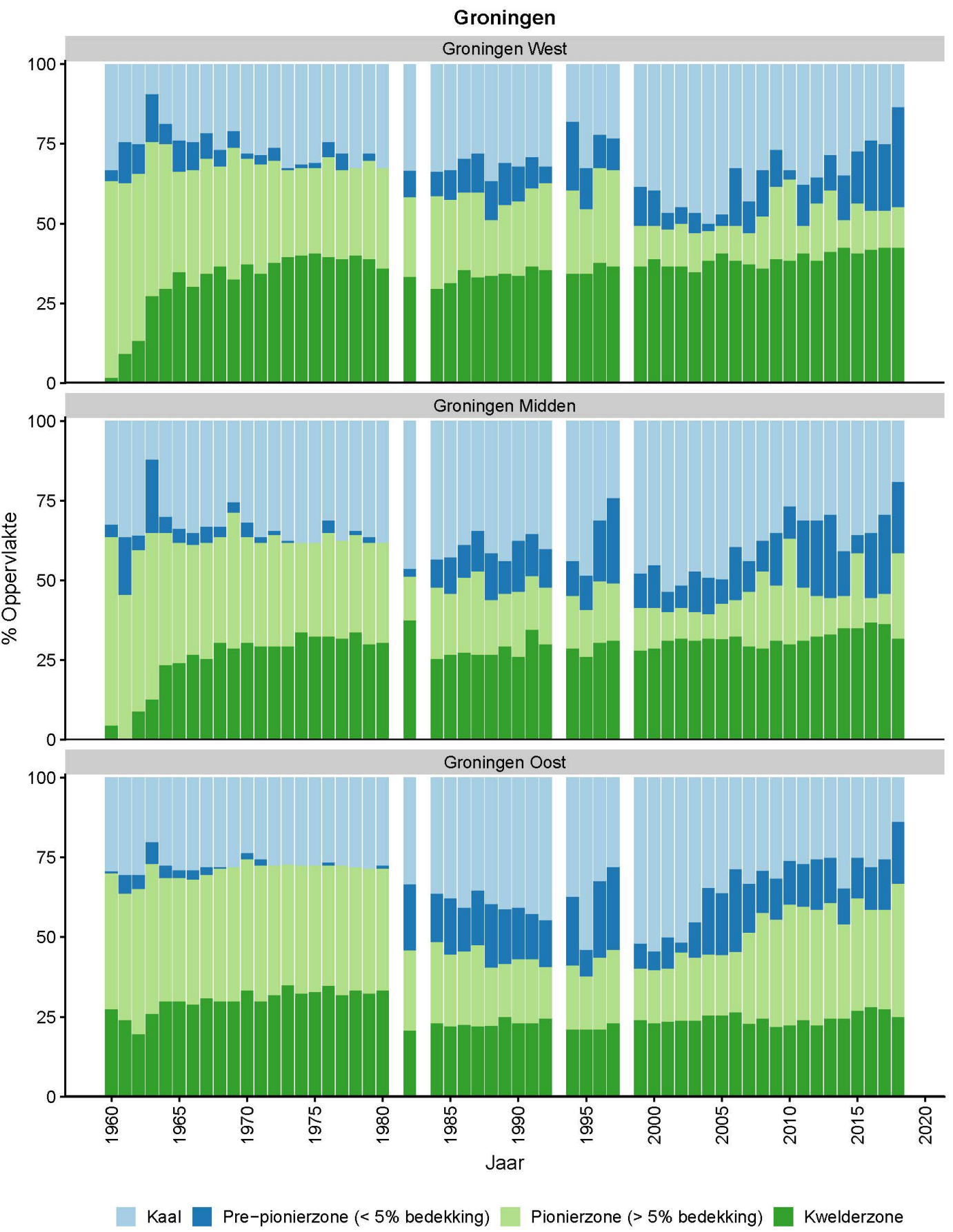

Figuur 3.5 Veranderingen in oppervlakte van kwelderzone, pionierzone, pre-pionierzone en kaal wad in de deelgebieden Groningen-West (250-331), Groningen-Midden (332-401) en Groningen-Oost (402-516). Deze zijn berekend in percentages bedekking ten opzichte van het hele meetvak. Kwelderzone en pionierzone zijn bepaald op basis van de SALT97-classificatie. Witte kolommen zijn missende gegevens.

In Groningen is het kwelderareaal licht toegenomen terwijl de pionierzone van jaar op jaar zeer variabel is (figuur 3.3). Deze was na 2006 flink toegenomen in alle drie deelgebieden maar laat tussen 2010 en 2014 weer een afname zien in Groningen-West en Groningen-Midden (figuren 3.3 en 3.5). Er zijn flinke uitschieters in 2015 en 2018. Dit waren dus zeer goede jaren voor de vestiging van pioniervegetatie, wat mogelijk het resultaat is van kalme winters met weinig erosie van de wadbodem in de pionierzone (van Regteren et al. 2019). De pioniervegetatie bestaat vooral uit eenjarige zeekraal, en jaar-op-jaar-variatie in omgevingsfactoren en zaadaanbod bepaalt of deze plant zich wel of niet kan vestigen (Houwing 2000, van Regteren et al. 2019). 


\subsubsection{Trends in plantendiversiteit binnen de kwelder (meetvakken)}

Zoals al eerder bleek uit de VEGWAD-karteringen (paragraaf 3.1) vindt in Friesland een toename plaats van lage kwelder met pioniersoorten (figuur 3.6). Dit komt al sinds de jaren tachtig structureel voor maar lijkt erg te variëren van jaar op jaar. In kwelderdelen die gedomineerd worden door lage kwelder vindt geleidelijk een toename plaats aan pionierplanten, doorgaans gedomineerd door klein schorrenkruid (zie ook bijlage 5, bv. meetvak 41-44). Dit hangt waarschijnlijk samen met de jaarlijks variërende inundatiefrequentie, verslechterde drainage, beweidingsintensiteit en neerslag. Een meer gedetailleerde analyse is nodig om de oorzaken van deze toename te achterhalen en of dit inderdaad een resultaat is van verminderde drainage zoals aangegeven in eerdere rapportages (Dijkema et al. 2013). Opvallend is dat de toenemende bedekking van lage kwelder met pioniersoorten (gebaseerd op de vegetatiekaarten; tabel 3.1) in Friesland-Midden binnen de meetvakken niet naar voren komt (figuur 3.6).

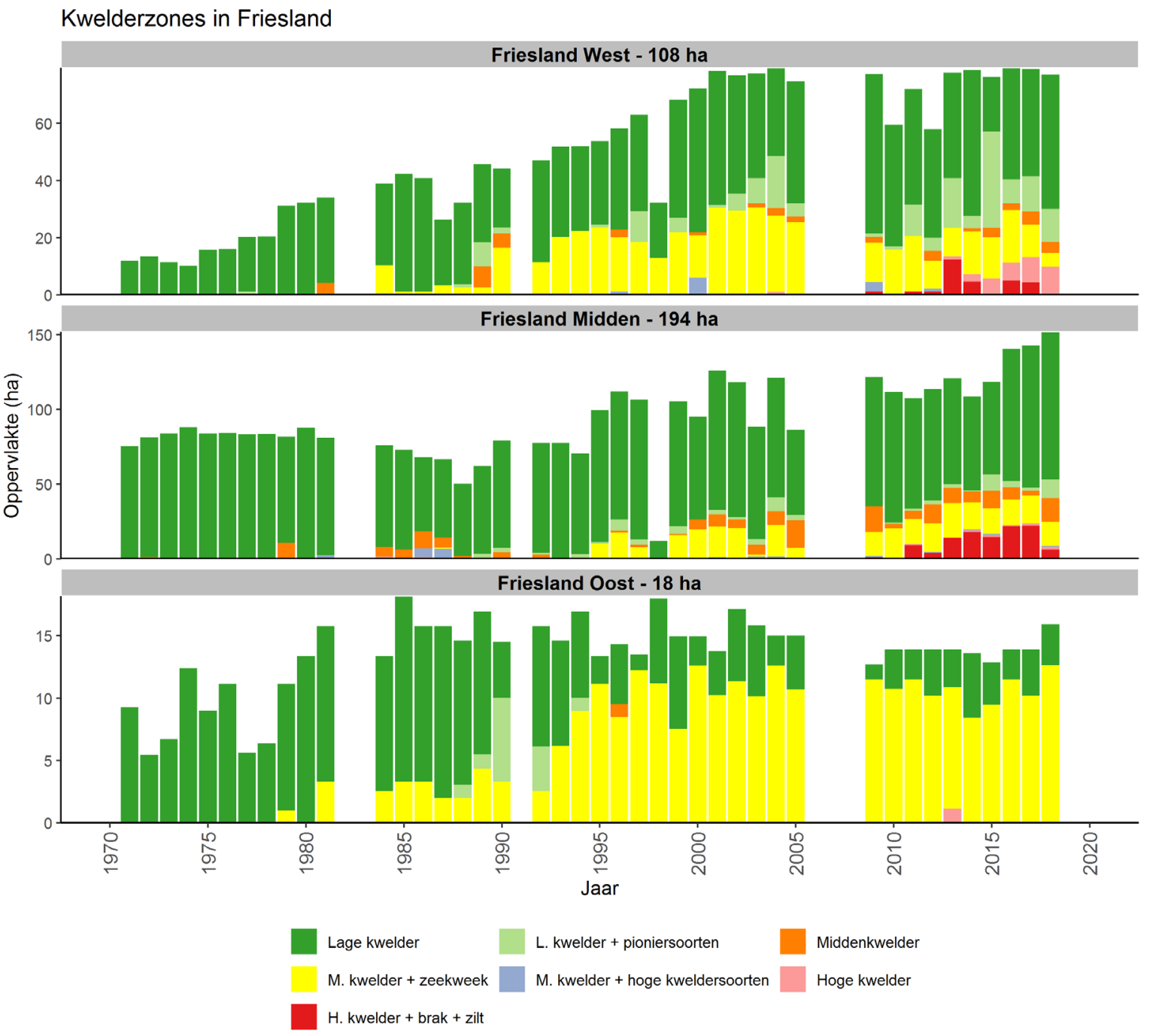

Figuur 3.6. Veranderingen in bedekking (ha) van verschillende vegetatiezoneringen binnen de kwelder in de deelgebieden Friesland-West (001-062), Friesland-Midden (063-186) en Friesland-Oost (187-249). De totale oppervlakte (kwelderzone + kaal wad) in 2018 binnen de meetvakken is weergegeven boven elke grafiek en bevat respectievelijk 4, 7 en 1 meetvak(ken) in Friesland-West, Friesland-Midden en Friesland-Oost. De vegetatiezoneringen zijn volgens de SALT97-classificatie weergegeven. Witte kolommen zijn missende gegevens. 
In de deelgebieden Friesland-West en Friesland-Midden is er sinds 2010 een toename van hoge kwelder met brakke en zilte vegetatie, terwijl de bedekking van midden kwelder (i.e. midden kwelder, + hoge kweldersoorten + zeekweek) afneemt. Dit is het gevolg van autonome successie waarbij een toenemende maaiveldhoogte en een afnemende overstromingsfrequentie zorgen voor een toename in brakke omstandigheden op de hogere kwelderdelen dichter bij de dijk.

Het meetvak in Friesland-Oost is vanaf het begin van de monitoring onbeweid. De bedekking met zeekweek is hier dan ook hoog. Sommige delen van Friesland-Oost worden wel beweid, maar deze gebieden bevinden zich buiten het gemeten meetvak. Friesland-Oost is bij uitstek geschikt als referentiegebied voor een vergelijking met beweide kwelders.

Kwelderzones in Groningen
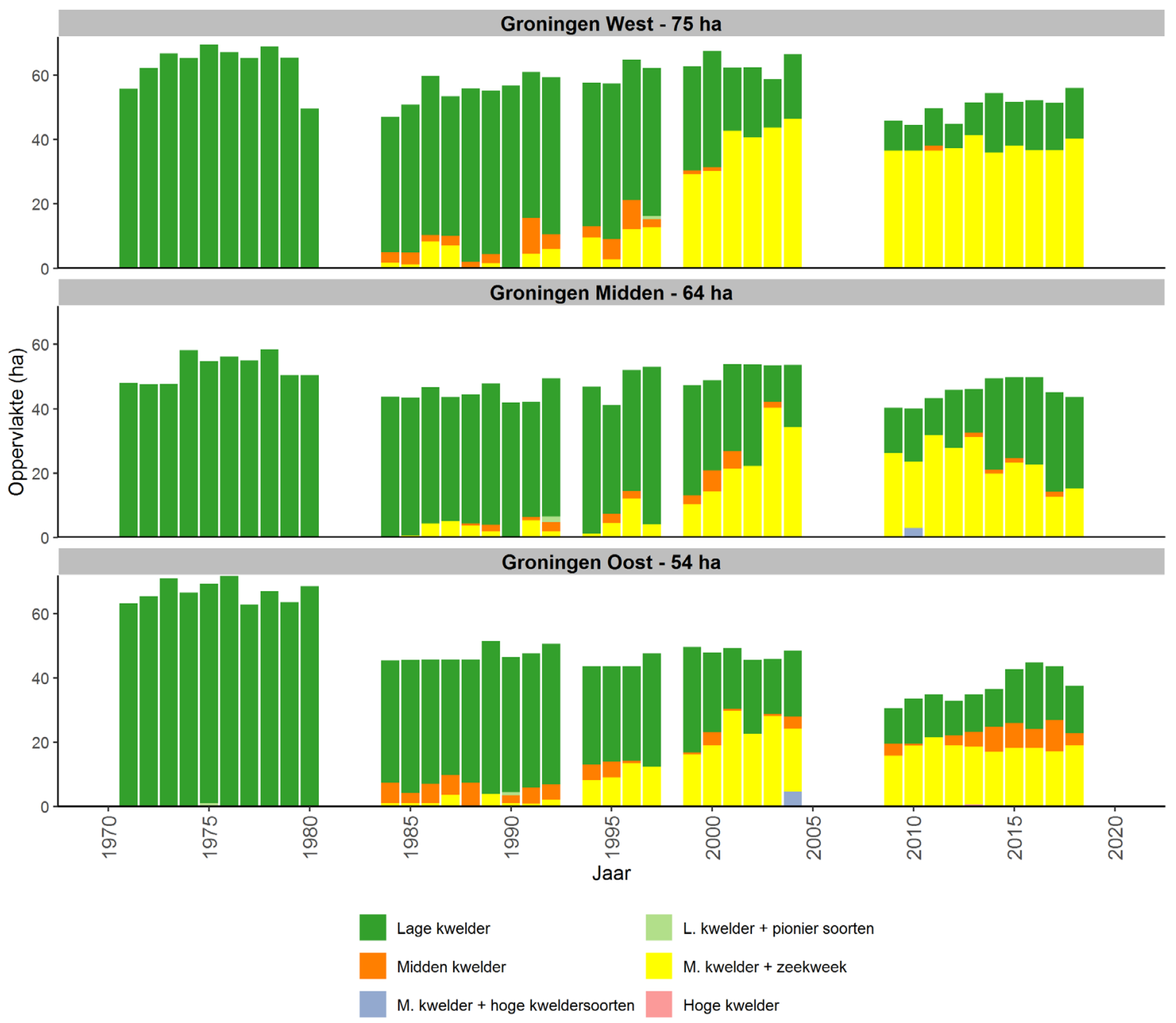

Figuur 3.7. Veranderingen in bedekking van verschillende vegetatiezoneringen binnen de kwelder in de deelgebieden Groningen-West (250-331), Groningen-Midden (332-401) en Groningen-Oost (402516). De totale oppervlakte (kwelderzone + kaal wad) in 2018 binnen de meetvakken is weergegeven boven elke grafiek en bevat respectievelijk 4, 4 en 5 meetvakken in Groningen-West, GroningenMidden en Groningen-Oost. De vegetatiezoneringen zijn volgens de SALT97-classificatie weergegeven. Witte kolommen zijn missende gegevens.

In Groningen is in de periode 2011-2013 het Groninger Kwelderherstelplan uitgevoerd (Oranjewoud 2010, Van Belle 2014). Door ophoging van gronddammen en dijkhekken gecombineerd met het verondiepen van een deel van het ontwateringssysteem, is de veiligheid voor vee verbeterd en kan het vee makkelijker hogere kwelderdelen bereiken als de kwelder overstroomt met hoogtij. Door het aanleggen van bruggen over de hoofdleidingen is het mogelijk gemaakt om grotere beweidingseenheden te vormen of vee makkelijker tussen aangrenzende kwelders te verplaatsen. De effecten van het kwelderherstelplan waren nog niet duidelijk zichtbaar in de vorige analyse van de meetvakken (van Duin et al. 2016) of in de analyse van de VEGWAD-vegetatiekaarten (paragraaf 
3.1). Uit figuur 3.7 blijkt dat er sinds 2013 in Groningen-Midden en Groningen-Oost een sterke afname is van kwelder gedomineerd door zeekweek. In beide deelgebieden is dit kweldertype bijna gehalveerd. In Groningen-Oost is er een sterke toename van midden kwelder terwijl in GroningenMidden de lage kwelder flink is toegenomen. Beide ontwikkelingen zullen vooral het effect zijn van een toename in beweidingsintensiteit (pararaaf 2.4). Opvallend is wel dat er tot het kwelderherstelplan werd geïmplementeerd er vrijwel alleen nog maar midden kwelder met zeekweek en lage kwelder voorkwamen (figuur 3.7).

\subsubsection{Vergelijking VEGWAD-karteringen met meetvakgegevens}

De gegevens van de jaarlijks opgenomen meetvakken zijn waardevol omdat daarmee kortetermijnveranderingen in areaal en kwaliteit van de vastelandskwelders kunnen worden opgemerkt en waar nodig snel kan worden ingegrepen. Alleen beslaan de meetvakken maar een deel van het gebied. Met de VEGWAD-kartering worden alle kwelders ingemeten, maar die kartering wordt maar eens in de zes jaar uitgevoerd. Door de bedekking van de verschillende vegetatiezones gebaseerd op de VEGWAD-karteringen en de meetvakgegevens met elkaar te vergelijken, kan worden bepaald of de veranderingen binnen de meetvakken representatief zijn voor alle vastelandskwelders.

Tabel 3.2 Vergelijking tussen de VEGWAD-karteringen (V) en de meetvakgegevens (M) voor de vastelandskwelders in Friesland. De bedekking (\%) van de verschillende vegetatiezoneringen is weergegeven voor verschillende jaren. Zomerpolders zijn niet meegenomen.

\begin{tabular}{|c|c|c|c|c|c|c|c|c|c|c|c|c|}
\hline \multirow{2}{*}{$\begin{array}{l}\text { Friesland } \\
\text { Vegetatiezonering }\end{array}$} & \multicolumn{2}{|c|}{1987} & \multicolumn{2}{|c|}{1992} & \multicolumn{2}{|c|}{1996} & \multicolumn{2}{|c|}{2002} & \multicolumn{2}{|c|}{2008} & \multicolumn{2}{|c|}{2014} \\
\hline & v & M & $\mathbf{v}$ & M & v & M & v & M & v & M & v & M \\
\hline Pre-pionierzone & 18 & 23 & 21 & 25 & 56 & 21 & 17 & 9 & 13 & 11 & 8 & 12 \\
\hline Pionierzone & 14 & 27 & 29 & 27 & 11 & 36 & 21 & 40 & 19 & 29 & 23 & 24 \\
\hline Lage kwelder & 54 & 41 & 39 & 41 & 22 & 28 & 21 & 32 & 19 & 30 & 13 & 30 \\
\hline $\begin{array}{l}\text { L. kwelder + } \\
\text { pioniersoorten }\end{array}$ & 0 & 0 & 0 & 2 & 4 & 2 & 2 & 2 & 16 & 5 & 20 & 7 \\
\hline Midden kwelder & 11 & 3 & 0 & 1 & 2 & 1 & 7 & 1 & 5 & 6 & 9 & 5 \\
\hline $\begin{array}{l}\text { M. kwelder + h. } \\
\text { kweldersoorten }\end{array}$ & 0 & 3 & 0 & 0 & 0 & 0 & 0 & 0 & 3 & 3 & 1 & 1 \\
\hline $\begin{array}{l}\text { M. kwelder + } \\
\text { zeekweek }\end{array}$ & 1 & 3 & 5 & 5 & 3 & 10 & 17 & 15 & 16 & 15 & 14 & 15 \\
\hline Hoge kwelder & 2 & 0 & 5 & 0 & 1 & 0 & 6 & 0 & 6 & 0 & 9 & 1 \\
\hline $\begin{array}{l}\text { Hoge kwelder }+ \\
\text { brak/zilte soorten }\end{array}$ & 0 & 0 & 1 & 0 & 0 & 0 & 10 & 0 & 3 & 0 & 3 & 6 \\
\hline
\end{tabular}

Tabel 3.3 Vergelijking tussen de VEGWAD-karteringen (V) en de meetvakgegevens (M) voor de vastelandskwelders in Groningen. De bedekking (\%) van de verschillende vegetatiezoneringen is weergegeven voor verschillende jaren. Zomerpolders zijn niet meegenomen.

\begin{tabular}{|c|c|c|c|c|c|c|c|c|c|c|c|c|c|c|}
\hline \multirow{2}{*}{$\begin{array}{l}\text { Groningen } \\
\text { Vegetatiezonering }\end{array}$} & \multicolumn{2}{|c|}{1982} & \multicolumn{2}{|c|}{1987} & \multicolumn{2}{|c|}{1992} & \multicolumn{2}{|c|}{1996} & \multicolumn{2}{|c|}{2002} & \multicolumn{2}{|c|}{2008} & \multicolumn{2}{|c|}{2014} \\
\hline & v & M & v & M & v & M & v & M & v & M & v & M & v & M \\
\hline Pre-pionierzone & 13 & 15 & 37 & 22 & 17 & 19 & 47 & 26 & 16 & 12 & 7 & 19 & 16 & 22 \\
\hline Pionierzone & 49 & 34 & 26 & 42 & 27 & 36 & 20 & 35 & 26 & 31 & 34 & 40 & 24 & 27 \\
\hline Lage kwelder & 33 & 51 & 30 & 30 & 30 & 38 & 23 & 26 & 22 & 27 & 20 & 12 & 23 & 20 \\
\hline $\begin{array}{l}\text { L. kwelder + } \\
\text { pioniersoorten }\end{array}$ & 0 & 0 & 0 & 0 & 0 & 1 & 0 & 0 & 0 & 0 & 1 & 0 & 3 & 0 \\
\hline Midden kwelder & 4 & 0 & 4 & 3 & 23 & 4 & 1 & 3 & 8 & 0 & 5 & 1 & 4 & 3 \\
\hline $\begin{array}{l}\text { M. kwelder + h. } \\
\text { kweldersoorten }\end{array}$ & 0 & 0 & 0 & 0 & 0 & 0 & 0 & 0 & 0 & 0 & 1 & 0 & 0 & 0 \\
\hline $\begin{array}{l}\text { M. kwelder + } \\
\text { zeekweek }\end{array}$ & 0 & 0 & 3 & 4 & 3 & 3 & 9 & 9 & 25 & 30 & 30 & 28 & 25 & 27 \\
\hline Hoge kwelder & 0 & 0 & 0 & 0 & 0 & 0 & 0 & 0 & 2 & 0 & 1 & 0 & 3 & 0 \\
\hline $\begin{array}{l}\text { Hoge kwelder }+ \\
\text { brak/zilte soorten }\end{array}$ & 0 & 0 & 0 & 0 & 0 & 0 & 0 & 0 & 0 & 0 & 0 & 0 & 0 & 0 \\
\hline
\end{tabular}


Beide datasets laten vergelijkbare trends zien. De grootste verschillen tussen de datasets zitten in de gemeten oppervlaktes van de pre-pionier en pionierzone. Dit komt door de verschillende methodes die worden gebruikt voor het bepalen van de vegetatiezones. De VEGWAD-karteringen gebruiken luchtfoto's en polygonen om vegetatietypen te classificeren, terwijl bij de meetvakken de vegetatie per $100 \times 100 \mathrm{~m}$ vlak geclassificeerd wordt. Verder is er in de VEGWAD-kartering van Friesland een grotere bedekking aan hoge kwelder gekarteerd, wat komt door het meenemen van de boerenkwelders (dichtbij de dijk). In de meetvakgegevens worden deze buiten beschouwing gelaten.

\subsubsection{Zeegras binnen de meetvakken}

Klein zeegras (Zostera noltii) kwam in het verleden erg veel voor in de Waddenzee maar is nu relatief zeldzaam. Na de afsluiting van de Zuiderzee is de bedekking met zeegras in de Waddenzee sterk afgenomen. Zeegras vormt een belangrijk onderdeel van het Waddenzee-ecosysteem en kan een hoge biodiversiteit waarborgen onder andere door als kraamkamer te functioneren voor vissen (Whitfield 2017). Om dit habitat in de Waddenzee te herstellen worden er regelmatig transplantaties uitgevoerd (van Katwijk et al. 2009).

Aangezien het lastig is te bepalen wat goede locaties zijn voor transplantaties, is er geïnventariseerd of zeegras al natuurlijk voorkomt binnen de meetvakken. Alleen klein zeegras is gevonden in de meetvakken langs de Groninger vastelandskust (Figuur 3.10). De laatste jaren is het aantal meetvakken waarin het voorkomt toegenomen. Het succesvol vestigen van zeegras word bepaald door de sedimentsamenstelling en de maaiveldhoogte (Philippart et al. 1992, Philippart en Dijkema 1995, van Katwijk en Wijgergangs 2004). Zeegras groeit het beste op plekken met slib in de bodem en heeft genoeg licht nodig voor fotosynthese, maar kan niet goed tegen lang droog staan. Het is niet helemaal duidelijk waarom klein zeegras de laatste jaren is uitgebreid, mogelijk heeft het wad door sedimentatie en/of erosie de juiste hoogte bereikt voor vestiging. Groningen-West is vooral aan het eroderen en Groningen-Oost juist aan het sedimenteren (Figuur 4.1 en 4.2), terwijl op beide plekken veel klein zeegras is opgekomen. Het kan ook zijn dat er de laatste jaren goede omstandigheden zijn voor ontkieming. Zeegras ontkiemt wanneer het water iets zoeter is (Hootsmans et al. 1987), maar de kiemplantjes zijn erg kwetsbaar en een storm kan leiden tot mortaliteit (van Katwijk en Hermus 2000). De bedekking met klein zeegras in de individuele subvakken is niet erg hoog: maximaal $3 \%$ in 2018.

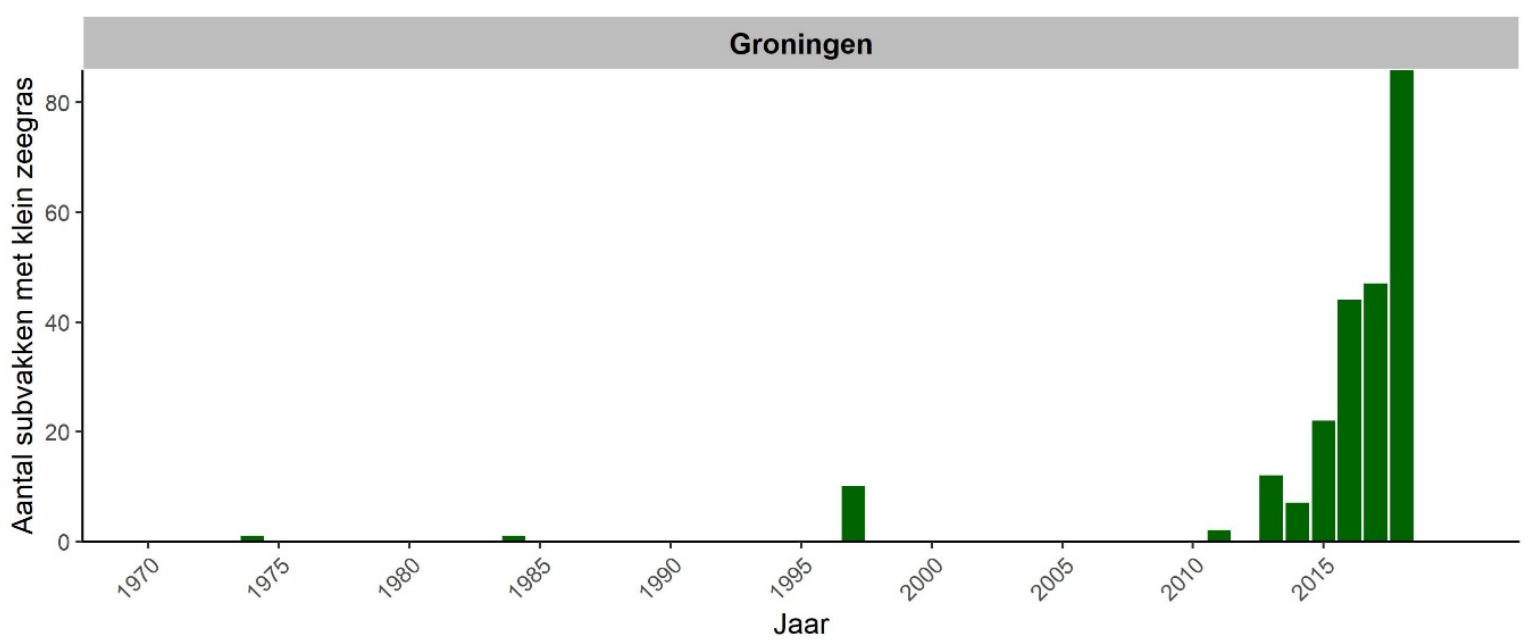

Figuur 3.10 Het aantal subvakken in Groningen waarin klein zeegras (Zostera noltii) is aangetroffen. NB. elk bezinkveld $(400 \times 400 \mathrm{~m})$ bestaat uit 16 subvakken $(100 \times 100 \mathrm{~m})$. 


\section{$4 \quad$ Ontwikkelingen maaiveldhoogte}

\subsection{Sedimentdynamiek en kwelders in de Waddenzee}

Kwelders zijn zeer dynamisch waar sedimentatie en erosie plaatsvindt onder invloed van het getij. Tijdens overstromingen met hoogwater en gedurende stormen wordt sediment afgezet (opslibbing) en hoogt het kweldermaaiveld langzaam op. De snelheid waarmee dit gebeurt hangt af van meerdere factoren, waaronder de afstand tot de sedimentbron (wadrand en/of kreek) en de aanwezige vegetatie. Met name stormen spelen een grote rol in de variatie in opslibbing en kunnen tot erosie leiden. Hoge, stugge vegetatie zal doorgaans de opslibbing stimuleren, terwijl beweiding het ophogen van het kweldermaaiveld remt door o.a. het compacteren van de kwelderbodem (Elschot et al. 2013, Nolte et al. 2013b). De netto maaiveldverandering per jaar wordt dus bepaald door de opslibbing, erosie en compactie van de bodem (compactie door vee en natuurlijke inklink) samen. De opslibbing vindt vooral plaats in het najaar en de winter, terwijl de natuurlijke inklink vooral in het voorjaar en de zomer plaatsvindt (figuur 1.4).

Tabel 4.1 Gemiddelde maaiveldophoging voor verschillende kwelders langs de kust (Friese en Groninger kwelderwerken), op de Dollardkwelders en voor twee eilandkwelders (Schiermonnikoog en Ameland). Waar mogelijk zijn de waarden gemiddeld over lage en midden kwelder.

\begin{tabular}{lll} 
Locatie & $\begin{array}{l}\text { Maaiveldophoging } \\
(\mathrm{mm} \text { per jaar })\end{array}$ & Bron \\
Noord-Friesland Buitendijks (Fr) & 16 & Wageningse SEB-meetnet \\
\hline Holwerd (Fr) & 22 & Wageningse SEB-meetnet \\
\hline Negenboerenpolder (Gr) & 7 & Wageningse SEB-meetnet \\
\hline Julianapolder (Gr) & 13 & Wageningse SEB-meetnet \\
\hline Schiermonnikoog & $2-4$ & (Elschot et al. 2015) \\
\hline Ameland & $4-6$ & (Elschot et al. 2017) \\
\hline Dollardkwelders & 8 & (Esselink et al. 2012)
\end{tabular}

In de half-natuurlijke kwelderwerken wordt erosie vermeden en sedimentbezinking bevorderd door de aanleg van rijzendammen. Hier is dan ook een hoge opslibbingssnelheid van soms wel enkele centimeters elk jaar (van Duin et al. 2016). Eilandkwelders hebben gemiddeld een lagere opslibbingssnelheid van enkele millimeters per jaar (tabel 4.1).

De bodemdaling op Ameland door gaswinning en de effecten daarvan op de kwelders geven een goed beeld van de te verwachten effecten van een versnelde zeespiegelstijging. Uit onderzoek uitgevoerd sinds 1986 op Ameland-Oost blijkt dat kwelderdelen ver verwijderd van een sedimentbron of slechtgedraineerde locaties (kommen) een verminderde ophoging hebben en niet kunnen compenseren voor de aanwezige bodemdaling (Elschot et al. 2017). De eilandkwelders hebben gemiddeld een lagere opslibbing en maaiveldophoging dan de vastelandskwelders (tabel 4.1), maar ook langs de Friese en Groninger kust varieert de maaiveldophoging net als tussen de verschillende kwelderzones (figuren 4.1, 4.2 en 4.3). De maaiveldophoging tussen wad, pionier- en kwelderzone varieert sterk van slechts enkele millimeters tot enkele centimeters per jaar (figuur 4.3). Met name in de pionierzone kan een lage bedekking met vegetatie tot een verminderde opslibbing en eventuele erosie leiden, wat in de kwelderwerken wordt tegengegaan met rijzendammen (Dijkema et al. 2013).

Ameland heeft gemiddeld een hogere opslibbing dan Schiermonnikoog wat waarschijnlijk een effect is van de bodemdaling door gaswinning (Elschot et al. 2017). In het algemeen neemt de opslibbing af naarmate de sedimentbron verder weg is en met de kwelderleeftijd (Elschot et al. 2015). De opslibbing in de lage en midden-kwelders is op vrijwel alle kwelders in het Nederlandse deel van de Waddenzee voldoende om de huidige zeespiegelstijging bij te houden. Met name op de hogere en oudere kwelders is de opslibbing minder dan $2 \mathrm{~mm}$ per jaar. Omdat ze zich op een hoger maaiveld 
bevinden, zijn deze kwelderdelen minder kwetsbaar voor een stijgende zeespiegel. Een mogelijk probleem in de toekomst is dat door een snelle opslibbing in de lagere delen de achterliggende kwelderdelen nabij de dijk of het duin relatief lager komen te liggen, de drainage afneemt en vernatting optreedt (Stock 2011). Lokaal stagnerend water zou dan tot regressie van de vegetatie kunnen leiden.

\subsection{Maaiveldhoogteontwikkelingen kwelderwerken 1960- 2018 (meetvakken)}

In vrijwel alle deelgebieden in Friesland en Groningen vindt opslibbing plaats in het eerste en tweede bezinkveld met gemiddeld $15 \mathrm{~mm}$ per jaar in Friesland en $10 \mathrm{~mm}$ per jaar in Groningen (figuren 4.1 en 4.2). Er is een algemene trend zichtbaar waarbij de jaarlijkse opslibbing in de eerste en derde bezinkvelden afneemt. Dit kan verklaard worden door een toenemende maaiveldhoogte in het eerste bezinkveld, terwijl het niet langer in onderhoud zijn van de buitenste rijzendammen de afname in het derde bezinkveld verklaard.

Wat verder opvalt is:

- In de deelgebieden Friesland-West, Friesland-Oost en Groningen-West neemt het maaiveld in het derde bezinkveld af. In Friesland is dit beperkt tot enkele $\mathrm{mm}$ per jaar, terwijl in Groningen-West de erosie substantiëler is. Ook in het eerste en tweede bezinkveld is er sinds 2010 in Groningen-West nauwelijks meer sprake van een netto opslibbing (figuur 4.2).

- De opslibbing in het derde bezinkveld in Friesland-West is sinds de jaren negentig gedaald, en de meest recente metingen laten nu een negatieve opslibbing zien (figuur 4.1). Hier is het omslagpunt bereikt van netto opslibbing naar netto erosie. Dit is goed verklaarbaar met het stoppen van het damonderhoud in 2006 aan de rijzendammen direct westelijk van dam 63.

De verandering in maaiveld is in bijlage 6 per meetvak weergegeven voor verschillende jaren in de periode 1965-nu. Voor de oriëntatie is het tweede bezinkveld duidelijk aangegeven in ieder figuur. 

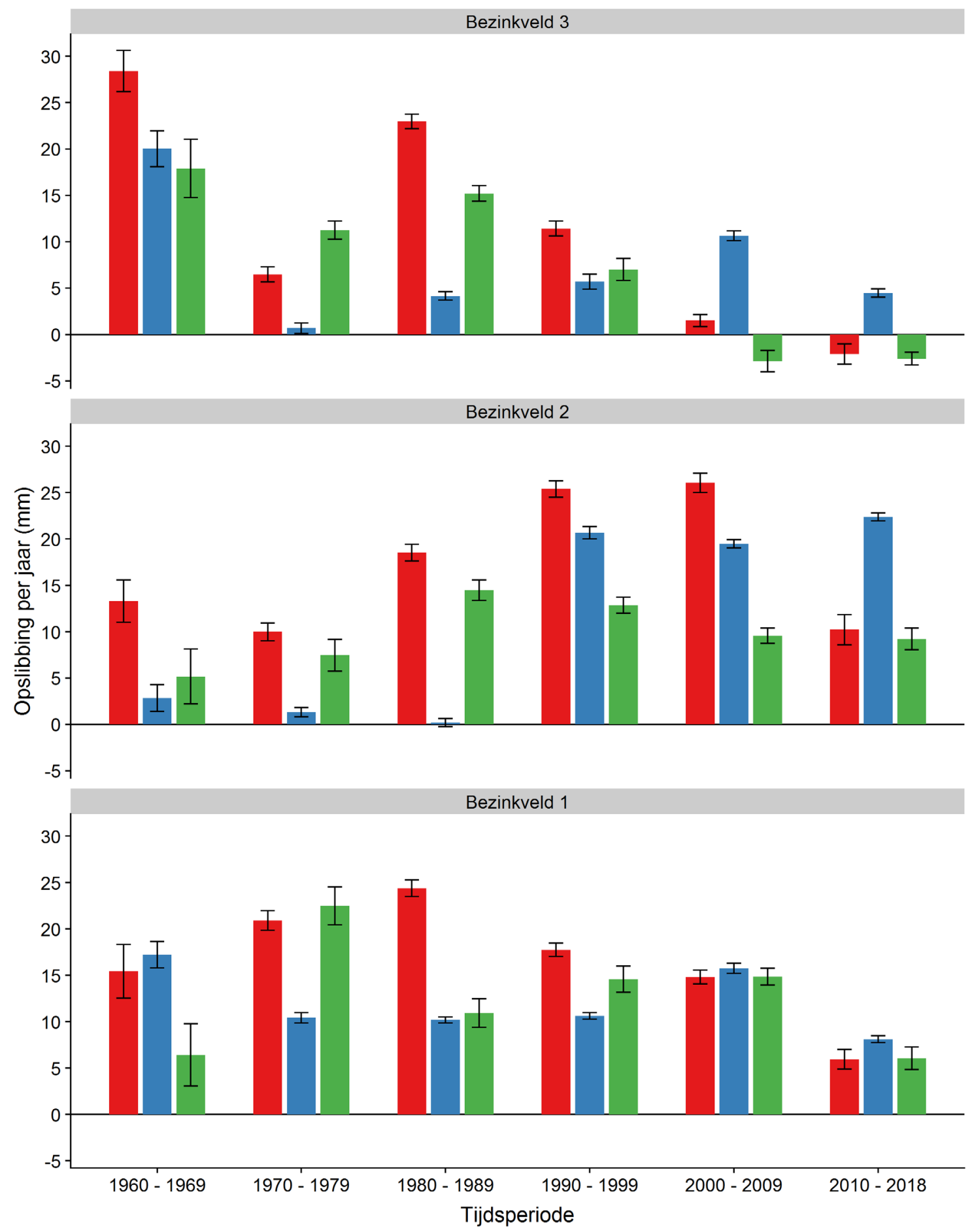

Friesland West $\square$ Friesland Midden $\square$ Friesland Oost

Figuur 4.1 Gemiddelde opslibbing in mm per jaar in de deelgebieden Friesland-West (001-062), Friesland-Midden (063-186) en Friesland-Oost (187-249), weergegeven per tien jaar. Bezinkveld 1 ligt het dichtst bij de dijk en bezinkveld 3 op het wad. 

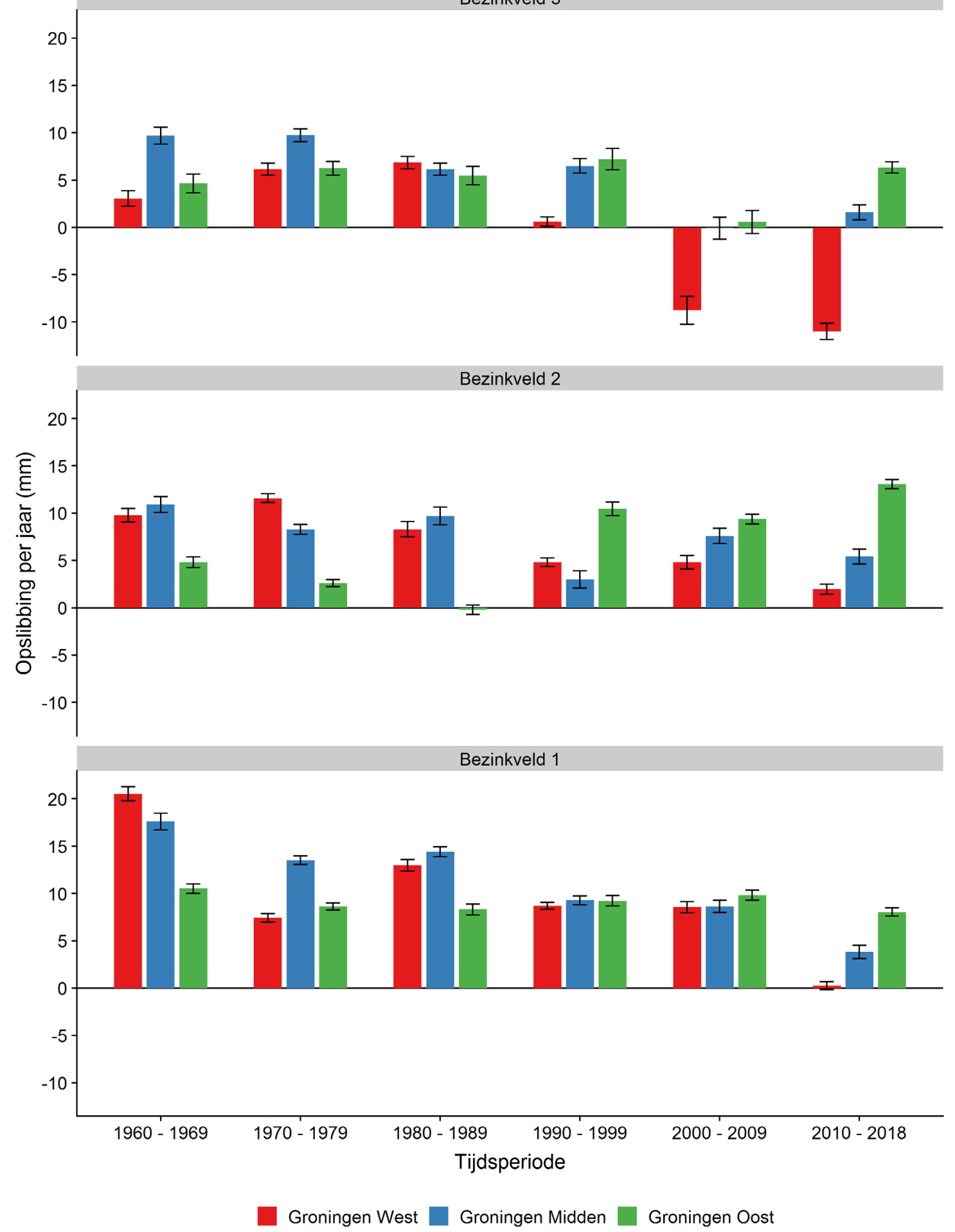

Figuur 4.2 Gemiddelde opslibbing in mm per jaar in de deelgebieden Groningen-West (250-331), Groningen-Midden (332-401) en Groningen-Oost (402-516), weergegeven per tien jaar. Bezinkveld 1 ligt het dichtst bij de dijk en bezinkveld 3 op het wad. 


\subsection{Opslibbing gerelateerd aan kwelderzone (SEB- meetnet)}

De gemiddelde jaarlijkse netto maaiveldverandering is voor alle vier locaties en vrijwel alle kwelderzones positief: er is meer opslibbing dan erosie of inklink (figuur 4.3). Op het wad in Groningen (Julianapolder en Negenboerenpolder) en tot 2008 deels ook in de pionierzone (Julianapolder) is er sprake van netto erosie. Door herstel van de rijzendammen in 2008 is de erosie gestopt, en is er nu weer sprake van netto opslibbing. In Friesland wordt deze zone niet meegenomen in het meetnet, maar gebaseerd op de resultaten van de meetvakken wordt op het wad in Friesland een positieve opslibbing verwacht. De lage kwelder en pionierzone hogen voldoende op om mee te kunnen komen met de huidige zeespiegelstijging van $2 \mathrm{~mm}$ per jaar. Zoals de Friese kwelders (NoordFriesland Buitendijks en Holwerd) laten zien, neemt de opslibbing af naarmate de kwelder hoger wordt. Dicht bij de dijk, op de hoge kwelder, blijft de kwelderhoogte vrijwel gelijk. Daar stijgt de kwelder dan ook niet mee met de huidige zeespiegelstijging en komt steeds lager te liggen ten opzichte van GHW. Doordat de lage kwelder en de pionierzone dichtbij het wad wel ophogen is er een risico dat de achterliggende hoge kwelders op den duur lager komen te liggen dan de voorliggende lage kwelder (badkuipeffect). Slechte drainage kan er dan voor zorgen dat er vernatting optreedt en meer schade aan de zachte bodems door vertrapping van vee, met regressie van de kweldervegetatie tot gevolg (Elschot et al. 2017). Met het huidige monitoringsnetwerk kan regressie vast worden gesteld, maar de processen die deze regressie veroorzaken kunnen alleen met extra veldmetingen worden geïdentificeerd.

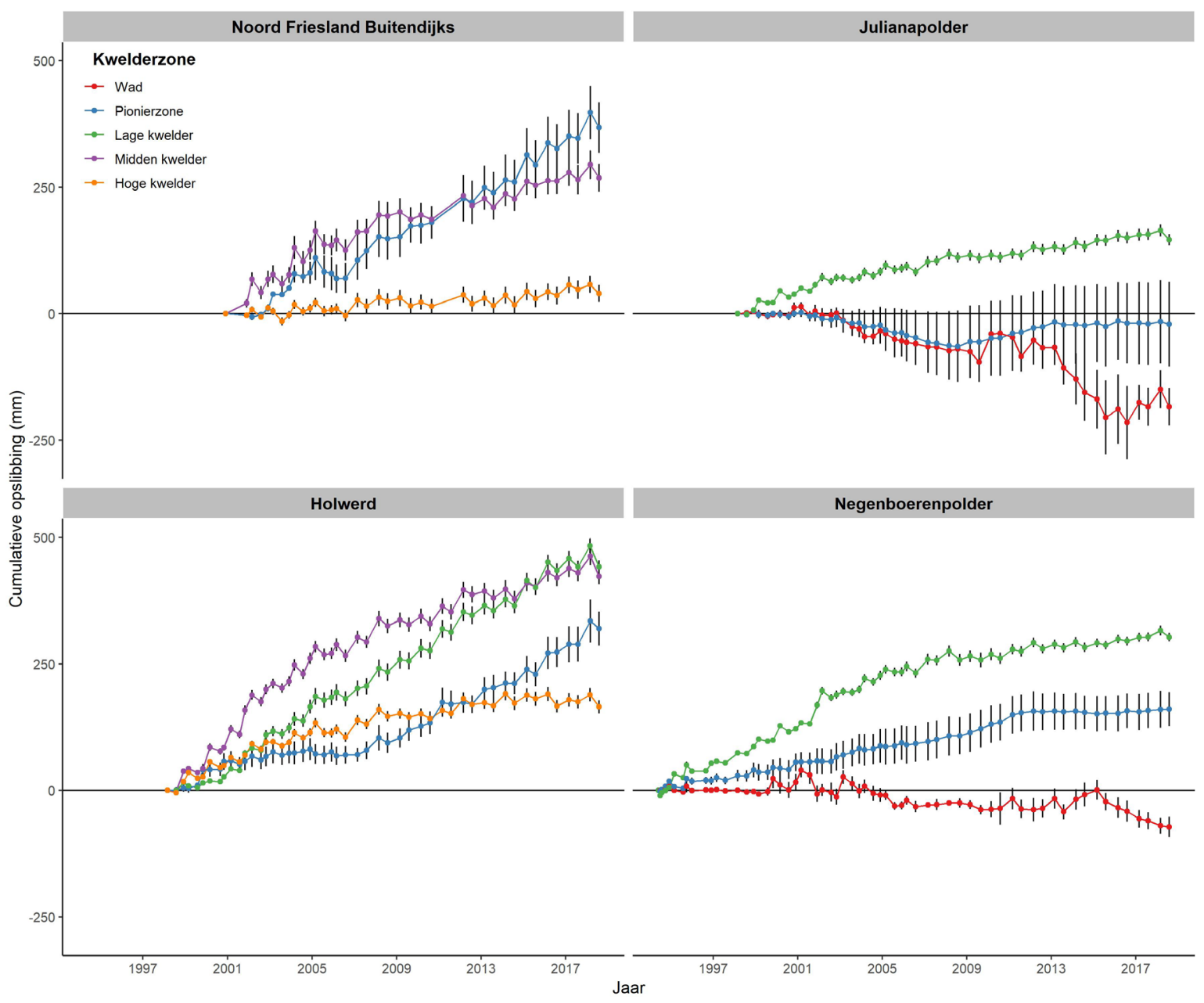

Figuur 4.3 Jaarlijkse maaiveldophoging (met standaarddeviatie) gemeten op vier locaties binnen de kwelderwerken (Wageningse SEB-meetnet). 


\subsection{Effecten van beweiding op de opslibbing (SEB- meetnet)}

Naast maaiveldhoogte en afstand tot de sedimentbron kan ook het huidige beheer een effect hebben op de maaiveldophoging. Uit onderzoek in Noord-Friesland Buitendijks en op Schiermonnikoog is gebleken dat beweiding door grote grazers de ophoging van het maaiveld kan remmen door biocompactie (Elschot et al. 2013, Nolte et al. 2013). Op de kwelders bij Holwerd is een groot aantal PQ's (74) verdeeld over de deels beweide en deels onbeweide kwelder. Deze PQ's zijn gemonitord over een periode van circa twintig jaar, waarmee bepaald kon worden welke factoren de maaiveldhoogte op de kwelder beïnvloeden.

De resultaten laten zien dat de sedimentatie vooral plaatsvindt in de winter (Figuur 4.4). Compactie (zowel autocompactie als biocompactie onder invloed van beweiding) domineert de maaiveldhoogteverandering in de zomer.

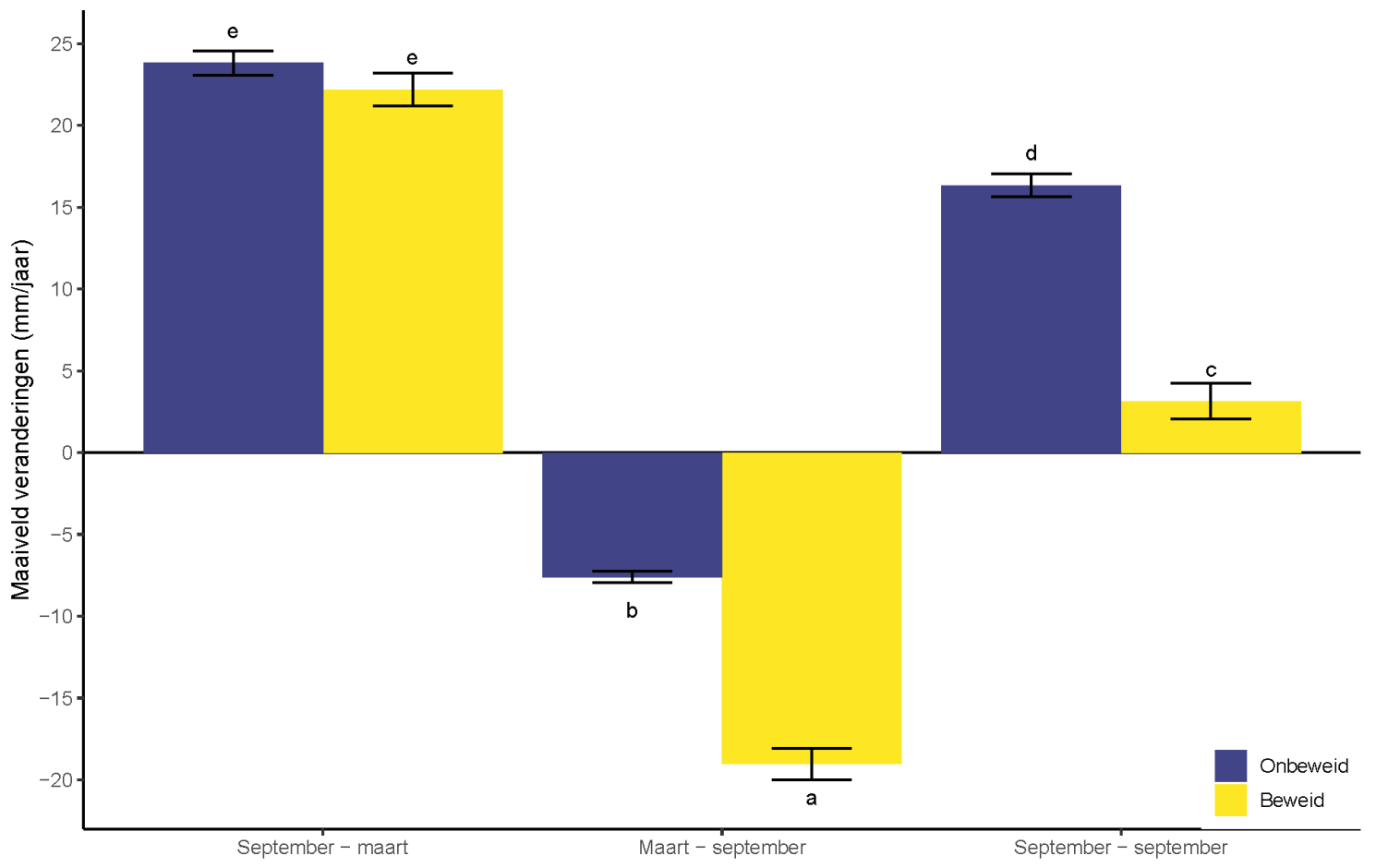

Figuur 4.4 Gemiddelde maaiveldverandering ( $\mathrm{mm} / \mathrm{jaar}$ ) met standaarddeviatie voor het winterseizoen (september - maart), zomerseizoen (maart - september) en over een heel jaar gerekend (september - september). 
Het belangrijkste verschil tussen de beweide en onbeweide kwelderdelen is de vegetatiehoogte en opslibbing: beweiding reduceert de vegetatiehoogte en cumulatieve opslibbing significant (Figuur 4.5 A-F). Er was geen significant verschil in de afstand tot de wadrand en de afstand tot de grootste kreek (Figuur 4.5 B \& C). De maaiveldhoogte verschilde initieel in 1998 wel tussen de onbeweide en beweide PQ's, maar dat verschil was niet meer aanwezig in 2015 (Figuur 4.5 D \& E). De cumulatieve opslibbing is lager in de beweide kwelder ten opzichte van de onbeweide kwelder, met een netto verschil van ongeveer $10 \mathrm{~cm}$ in zeventien jaar (Figuur $4.5 \mathrm{~F}$ ).

A

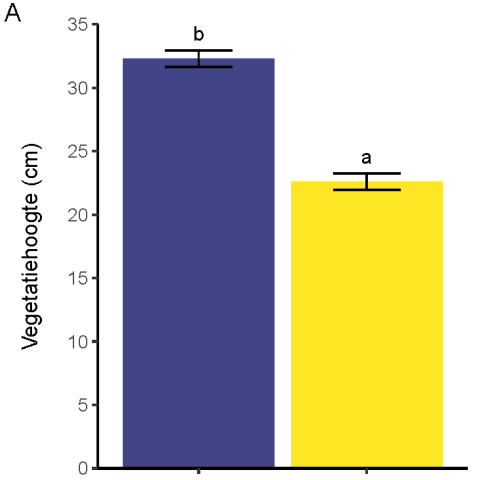

D

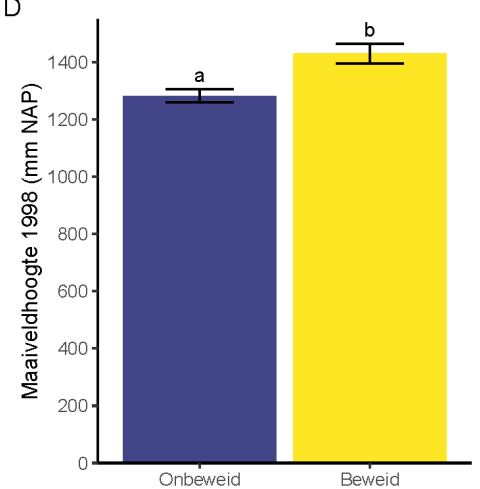

B

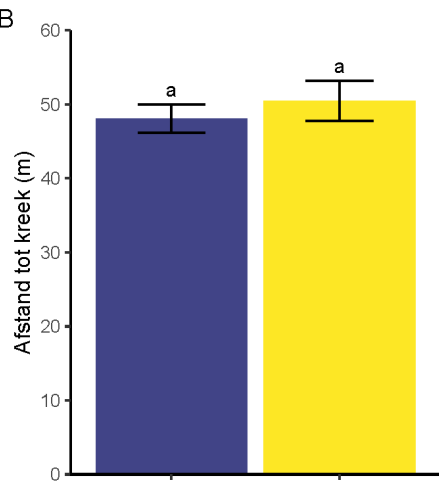

E

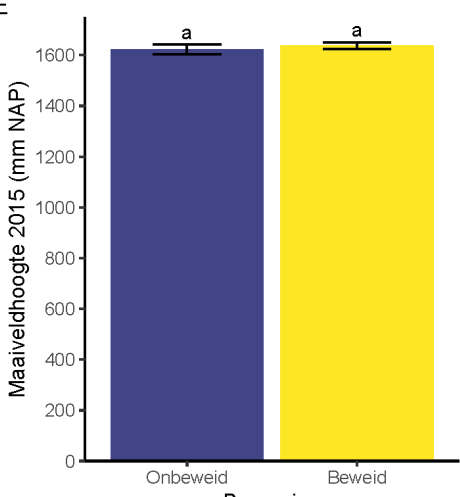

C

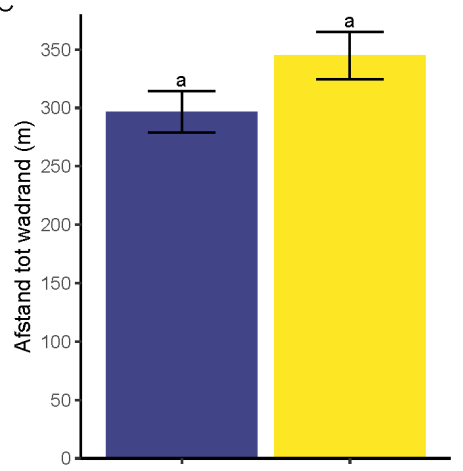

F

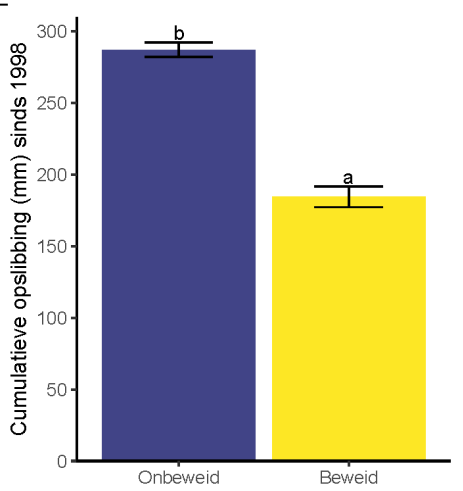

Figuur 4.5 De gemiddelden (met standaarddeviatie) tussen onbeweide en beweide kwelders voor: A) vegetatiehoogte $(\mathrm{cm}), B$ ) afstand tot de kreek $(m), C)$ afstand tot de wadrand $(m), D)$ maaiveldhoogte in 1998 ( $\mathrm{mm}$ boven NAP), E) maaiveldhoogte in 2015 ( $\mathrm{mm}$ boven NAP), en F) cumulatieve opslibbing ( $\mathrm{mm}$ ) tussen 1998 en 2015. Letters (a) en (b) boven elke kolom geven significante verschillen weer, letters (a) en (a) zijn niet-significante verschillen. 
Binnen de kwelder wordt de sedimentatiesnelheid in de winter vooral bepaald door de afstand tot de wadrand, inundatiefrequentie en vegetatie (figuur 4.6A, tabel 4.2). De hoogste sedimentatie vindt plaats op $100 \mathrm{~m}$ afstand van de wadrand. De volgende belangrijkste factor is het aantal overstromingen (inundatiefrequentie, tabel 4.2). Dit is geen lineaire trend: de sedimentatie neemt toe tot een inundatiefrequentie van 75 keer per jaar, en daarna neemt de sedimentatie weer af (figuur 4.6C). Dit kan verklaard worden doordat PQ's die relatief laag liggen ten opzichte van GHW, vaker overstromen en veelal een lagere vegetatiebedekking hebben, die mogelijk het sediment minder goed vasthoudt. Beweiding vindt alleen plaats in de zomer en heeft dan ook geen significant effect op de wintersedimentatie. De afstand tot de kreek heeft geen significant effect op de maaiveldhoogteverandering in zomer of winter. De compactie in de zomer wordt vooral significant beïnvloed door beweiding. Als we dan kijken naar de factoren die de verandering in maaiveldhoogte jaarrond het sterkst beïnvloeden dan zijn dat: de afstand tot de kwelderrand, beweiding en vegetatiehoogte. Daarna komen inundatiefrequentie en is er een minimaal effect van vegetatiebedekking.

Tabel 4.2 Resultaten van het statistisch model waarbij de effecten van beweiding, afstand tot sedimentbron (kwelderrand en kreek), inundatiefrequentie en vegetatie zijn getoetst aan de maaiveldverandering in winter (links), zomer (midden) en jaarrond (rechts). Significante effecten zijn vetgedrukt weergegeven, $* p<0.05, * * p<0.01, * * * p<0.001$.

\begin{tabular}{|c|c|c|c|c|c|c|}
\hline \multirow[b]{2}{*}{ Factoren } & \multicolumn{2}{|c|}{$\begin{array}{l}\text { Winter-sedimentatie } \\
\text { (september - maart) }\end{array}$} & \multicolumn{2}{|c|}{$\begin{array}{l}\text { Zomer-compactie } \\
\text { (maart - september) }\end{array}$} & \multicolumn{2}{|c|}{$\begin{array}{l}\text { Netto maaiveldophoging } \\
\text { (jaarrond) }\end{array}$} \\
\hline & Vol Model & $\mathbf{R}^{2}$ & Vol model & $\mathbf{R}^{2}$ & Vol model & $\mathbf{R}^{2}$ \\
\hline Beweiding & -2.2 & 0.003 & $-11.1 * * *$ & 0.147 & $-12.9 * * *$ & 0.09 \\
\hline \multicolumn{7}{|l|}{ Afstand tot } \\
\hline kwelderrand & $-8.9 * * *$ & 0.2 & $2.2 * * *$ & 0.038 & $-6.3 * * *$ & 0.112 \\
\hline Afstand tot kreek & -0.4 & 0.001 & 0.5 & 0.002 & 0.2 & 0 \\
\hline Vegetatiehoogte & $-2.2 * * *$ & 0.017 & 0.3 & 0.001 & $-1.7 * * *$ & 0.011 \\
\hline Inundatiefrequentie & $-5.8 * * *$ & 0.083 & $3.7 * * *$ & 0.082 & $-1.8 * *$ & 0.009 \\
\hline Vegetatiebedekking & $1.2 *$ & 0.005 & 0.3 & 0.001 & $1.2 *$ & 0.005 \\
\hline Observaties & 1238 & NA & 1169 & NA & 1238 & NA \\
\hline Marginale $\mathrm{R}^{2}$ & 0.15 & NA & 0.25 & NA & 0.17 & NA \\
\hline Conditionale $\mathrm{R}^{2}$ & 0.5 & NA & 0.35 & NA & 0.46 & NA \\
\hline Log Likelihood & -5118 & NA & -4299 & NA & -5093 & NA \\
\hline AIC & 10255 & NA & 8616 & NA & 10203 & NA \\
\hline $\mathrm{BIC}$ & 10301 & NA & 8661 & NA & 10250 & NA \\
\hline
\end{tabular}



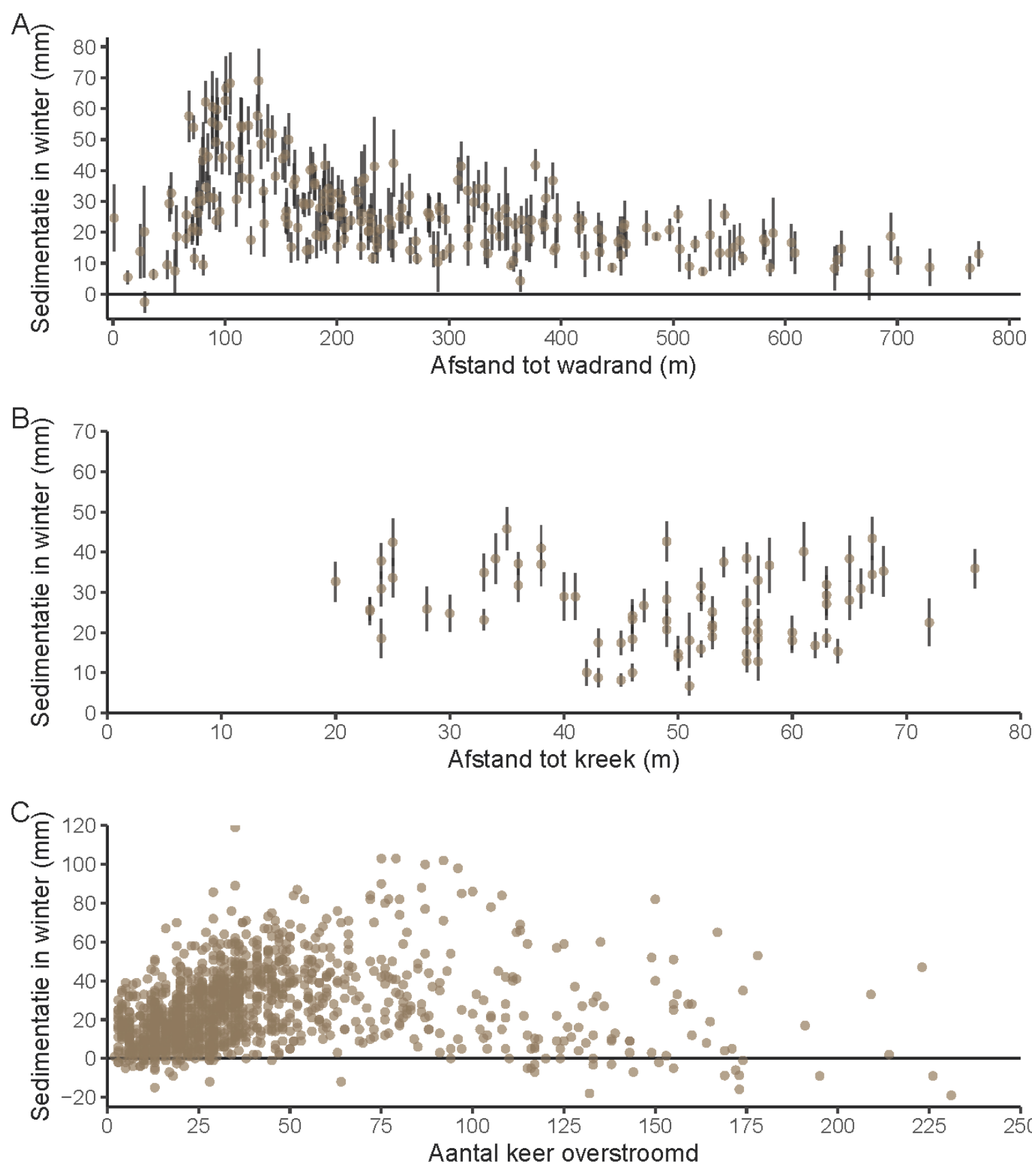

Figuur 4.6 De relatie tussen A) de afstand tot de wadrand en de sedimentatie in de winter; B) de afstand tot de kreek en de sedimentatie in de winter; $C$ ) het aantal overstromingen en de sedimentatie in de winter. Voor grafiek $A$ en $B$ : de punten geven de gemiddelden aan en de lijnen de standaarddeviatie. 



\section{Conclusies en aanbevelingen}

\subsection{Kwelderareaal en plantendiversiteit}

\subsubsection{Kwelders in de Waddenzee}

Na een dieptepunt halverwege de twintigste eeuw is het kwelderareaal in de Waddenzee in de afgelopen decennia (1999 - 2017) weer geleidelijk toegenomen. Dit komt door uitbreiding van de kwelders richting het oosten op de Waddeneilanden, door aangroei van de vastelandskwelders (met name in Friesland) en door enkele ontpolderingsprojecten langs de Friese kust. Op de kwelders vinden diverse veranderingen in de vegetatie plaats. Op de oostelijke Waddeneilanden is de climaxvegetatie van hoge kwelder met zeekweek toegenomen, wat het gevolg is van autonome successie in de grotendeels onbegraasde kwelders. In de Dollard zien we vooral een afname aan brakke vegetatie en hoge kwelder vegetatie met zeekweek onder invloed van beweiding en vernatting. Langs de vastelandskust zien we een geleidelijke uitbreiding van de kwelder richting de buitenste nog in onderhoud zijnde rijzendammen waardoor de pionierzone in de knel komt en afneemt. Langs de Friese kust neemt het areaal aan lage kwelder met pioniersoorten toe, wat duidt op een toename van beweidingsdruk en/of verminderde drainage. Daarnaast neemt het areaal aan hoge kwelder met brakke en zilte vegetatie toe in de deelgebieden Friesland-West en Friesland-Midden, wat het gevolg kan zijn van autonome successie. Een hoge opslibbing leidt tot een afname van overstromingen en een toename van brakke omstandigheden. Hierdoor kunnen zich ook minder zouttolerante plantensoorten vestigen en handhaven. In Groningen worden de eerste effecten van het kwelderherstelplan zichtbaar (uitgevoerd in de periode 2011-2013): een toename in beweiding resulteert in een afname in door zeekweek gedomineerde middenkwelder ten gunste van lage kwelder. De pionierzone is in Groningen afgenomen sinds 2010, maar in de periode 2014-2017 stabiel gebleven. 2015 en 2018 laten een heel hoge bedekking aan pioniervegetatie zien. Dit waren zeer gunstige jaren voor zeekraal.

In de Waddenzee worden verschillende initiatieven ondernomen voor het herstel van zeegrasvelden. Daarom is in dit rapport een extra inventarisatie opgenomen van de aanwezigheid van zeegras binnen de meetvakken. Het blijkt dat het aanwezig is in de Groninger meetvakken, en het aantal subvakken waarin ze voorkomen is flink toegenomen in de periode 2012-2018. De bedekking met klein zeegras in de individuele subvakken is niet erg hoog: maximaal $3 \%$ in 2018.

\subsubsection{Functie-eisen Rijkswaterstaat (kwelderwerken)}

De Friese en Groninger kwelders langs de kust samen (i.e. de kwelderwerken) zijn getoetst aan drie van de vier functie-eisen die de richtlijn vormen voor het beheer en onderhoud van RWS:

1. het huidige kwelderareaal van 4.334 ha binnen de kwelderwerken voldoet ruimschoots aan de gestelde eis van 1.250 ha;

2. op drie locaties langs de Groninger kust is de kweldergrens iets voorbij de oude afgepaalde kweldergrens teruggetrokken richting dijk, waarmee niet volledig is voldaan aan de betreffende eis;

3. het huidige areaal aan pionierzone van 1.020 ha binnen de kwelderwerken voldoet aan de gestelde eis van 750 ha;

4. aan functie-eis $4 \mathrm{zal}$ na nader overleg met de beheerders en gebruikers worden getoetst.

\subsection{Maaiveldontwikkeling en zeespiegelstijging}

Doordat vrijwel alle kwelders in de Waddenzee elk jaar gemiddeld enkele millimeters (eilandkwelders) tot enkele centimeters (vastelandskwelders) ophogen, kunnen ze meegroeien met de huidige zeespiegelstijging. Als de zeespiegel sneller gaat stijgen, zoals wordt voorspeld in verschillende 
scenario's (Vermeersen et al. 2018), dan zullen niet alle kwelders mee kunnen komen en op den duur mogelijk verdrinken (Kirwan et al. 2010).

In de kwelderwerken is in vrijwel alle deelgebieden en bezinkvelden een positieve opslibbing, uitgezonderd het derde bezinkveld (kaal wad) in Friesland-West, Friesland-Oost en Groningen-West. In Friesland-West en Friesland-Oost is er een beperkte afname in kweldermaaiveldhoogte van enkele millimeters per jaar. In Groningen-West is dit gemiddeld $11 \mathrm{~mm}$ per jaar in de periode 2010-2018 bij de Negenboerenpolder. Binnen de kwelderzone zien we dat de sedimentatiesnelheid met de afstand tot de kwelderrand afneemt. De hoge kwelder het dichtst bij de dijk hoogt nauwelijks meer op; deze kan daardoor op den duur steeds lager komen te liggen ten opzichte van de voorliggende lage kwelder en GHW. Hierbij is het onzeker of dit deel weer sneller gaat opslibben als door zeespiegelstijging de inundatiefrequentie hier toeneemt.

Vermeersen et al. (2018) heeft een studie gedaan naar de verwachte zeespiegelstijging onder verschillende scenario's van het AR5 IPCC-rapport (2014). De voornaamste scenario's die gebruikt zijn: RCP 2.6 (in dit scenario neemt het $\mathrm{CO}_{2}$-verbruik af vanaf 2020) en RCP 8.5 (waarbij het $\mathrm{CO}_{2}$ verbruik zal blijven toenemen in de eenentwintigste eeuw). In het RCP 2.6-scenario is de prognose dat in 2100 de zeespiegelstijging is gestegen tot $2,2 \mathrm{~mm}$ per jaar. Dit is maar een kleine toename van de huidige zeespiegelstijging (2,0 mm per jaar ) en zal waarschijnlijk geen probleem zijn voor het voortbestaan van de kwelders. In het RCP 8.5-scenario is er een zeespiegelstijging in 2100 van 18,3 $\mathrm{mm}$ per jaar wat een aanzienlijke stijging is vergeleken met de huidige zeespiegelstijging. De opslibbing van de kwelders van de Waddenzee verschillen per gebied maar is bij de vastelandskwelders het hoogst met gemiddelden tot enkele centimeters per jaar. De opslibbing zal in de meeste kwelders te laag zijn om de zeespiegelstijging van het RCP 8.5-scenario bij te houden tenzij de opslibbingssnelheid door een hogere inundatiefrequentie als gevolg van de zeespiegelstijging toeneemt. Uit modelstudies blijkt, en dit wordt gevalideerd met de resultaten uit dit rapport, dat kwelderdelen landinwaarts verder weg van de kwelderrand mogelijk eerder zullen verdrinken omdat daar de opslibbing lager is dan aan de rand van de kwelders.

Nu zijn door Vermeersen et al. (2018) de twee extreemste scenario's meegenomen, terwijl de uiteindelijke zeespiegelstijging waarschijnlijk tussen deze twee scenario's in zal liggen. In dit rapport is vooral gekeken naar de verticale groei van de kwelders maar zeespiegelstijging en klimaatverandering hebben waarschijnlijk ook een effect op de laterale groei (en afslag) van de kwelders, afhankelijk van erosie tijdens stormen en het sedimentaanbod. Verdere studie naar de effecten van klimaatverandering op de kwelders in de Waddenzee wordt dan ook aanbevolen.

\subsection{Aanbevelingen}

1. Nader overleg is nodig met beheerders en gebruikers van kwelders in de werkgroep kwelderwerken over functie-eis 4 van RWS: "Waterplassen en kale plekken op de kwelder die zijn ontstaan als gevolg van stagnatie in de waterafvoer, mogen per geval niet groter zijn dan 0,1 ha en gezamenlijk niet groter dan $5 \%$ van het totale oppervlakte".

2. Verdere studies naar de klimaatadaptatie van kwelders in relatie tot zeespiegelstijging worden aanbevolen. Om de effecten van klimaatverandering op kwelders te kunnen voorspellen is langlopende monitoring nodig, waarbij niet alleen verticale groei maar ook laterale kweldergroei meegenomen wordt. Hierbij is extra aandacht nodig voor delen van het wad waar erosie plaatsvindt en voor kwelders waar de opslibbing onvoldoende is om de zeespiegelstijging te kunnen bijhouden.

3. Zeekraal is een eenjarige pionierplant (H1310) en de bedekking met zeekraal kan van jaar op jaar sterk variëren. Omdat de VEGWAD-vegetatiekaarten slechts eenmaal per zes jaar worden gemaakt maar de belangrijkste bron vormen voor de Natura 2000-rapportages, is er het risico dat het bij een opname net om een goed dan wel slecht zeekraal-jaar gaat. De zeekraalbedekking wordt in de meetvakken jaarlijks gemeten en daarmee kan onderzocht worden of externe factoren zoals winterstormen of de temperatuur in het voorjaar, de bedekking in de zomer bepalen. 
4. De bedekking van lage kwelder met pioniersoorten breidt geleidelijk uit langs de Friese kust. Dit komt mogelijk door veranderingen in drainage en/of vertrapping door vee. Hogere sedimentatiesnelheden aan de kwelderrand kunnen ervoor zorgen dat de achterliggende hoge kwelder op den duur lager komen te liggen dan de voorliggende lage kwelder (badkuipeffect). Slechte drainage kan er vervolgens voor zorgen dat er vernatting optreedt en meer schade aan de zachte bodems door vertrapping van vee, met regressie van de kweldervegetatie tot gevolg (Elschot et al. 2017). Met het huidige monitoringsnetwerk kan regressie vast worden gesteld, maar de processen die deze regressie veroorzaken kunnen alleen met extra veldmetingen worden geïdentificeerd. Doordat in lage kwelders meerjarige planten worden vervangen door eenjarige planten kunnen deze kwelderdelen verder ontwikkelen tot een kale bodem wat doorgaans samengaat met erosie. Het is belangrijk deze veranderingen nauwlettend te monitoren en de processen achter deze uitbreiding te begrijpen om de beheerders en eigenaren te kunnen adviseren over noodzakelijke ingrepen. 



\section{Literatuur}

Armstrong, W., E. J. Wright, S. Lythe, and T. J. Gaynard. 1985. Plant Zonation and the Effects of the Spring-Neap Tidal Cycle on Soil Aeration in a Humber Salt Marsh. The Journal of Ecology 73:323.

Baptist, M. J., J-T. van der Wal, E. O. Folmer, U. Gräwe and K. Elschot. 2019a. An ecotope map of the trilateral Wadden Sea. Journal of Sea Research 152:101761.

Baptist, M. J., T. Gerkema, B. C. van Prooijen, D. S. van Maren, M. van Regteren, K. Schulz, I. Colosimo, J. Vroom, T. van Kessel, B. Grasmeijer, P. Willemsen, K. Elschot, A. V. de Groot, J. Cleveringa, E. M. M. van Eekelen, F. Schuurman, H. J. de Lange, and M. E. B. van Puijenbroek. 2019b. Beneficial use of dredged sediment to enhance salt marsh development by applying a 'Mud Motor.' Ecological Engineering 127:312-323.

van Belle, J. 2014. Beheerplan Groninger kwelders Periode 2015 - 2020. Feanwalden.

Bockelmann, A. C., J. P. Bakker, R. Neuhaus, and J. Lage. 2002. The relation between vegetation zonation, elevation and inundation frequency in a Wadden Sea salt marsh. Aquatic Botany 73:211221.

Boorman, L. A., and J. Hazelden. 2017. Managed re-alignment; a salt marsh dilemma? Wetlands Ecology and Management 25:387-403.

Bouma, T. J., L. A. van Duren, S. Temmerman, T. Claverie, A. Blanco-Garcia, T. Ysebaert, and P. M. J. Herman. 2007. Spatial flow and sedimentation patterns within patches of epibenthic structures: Combining field, flume and modelling experiments. Continental Shelf Research 27:1020-1045.

Cahoon, D. R. 2006. A review of major storm impacts on coastal wetland elevations. Estuaries and Coasts 29:889-898.

Cahoon, D. R., B. C. Perez, B. D. Segura, and J. C. Lynch. 2011. Elevation trends and shrink-swell response of wetland soils to flooding and drying. Estuarine, Coastal and Shelf Science 91:463-474.

Common Wadden Sea Secretariat, 2010. Wadden Sea Plan 2010. Eleventh Trilateral Governmental Conference on the Protection of the Wadden Sea. Common Wadden Sea. Secretariat, Wilhelmshaven, Germany.

Day, J. W., G. P. Kemp, D. J. Reed, D. R. Cahoon, R. M. Boumans, J. M. Suhayda, and R. Gambrell. 2011. Vegetation death and rapid loss of surface elevation in two contrasting Mississippi delta salt marshes: The role of sedimentation, autocompaction and sea-level rise. Ecological Engineering 37:229-240.

Dijk, D. 2020. Instandhoudingsplan. Kwelderwerken Friese en Groninger kust. RWS Noord-Nederland.

Dijkema, K. S. 1987a. Geography of salt marshes in Europe. Zeitschrift für Geomorphologie 31:489199.

Dijkema, K. S. 1987b. Changes in salt-marsh area in the Netherlands Wadden Sea after 1600. Pages 42-49 in A. H. L. Huiskes, C. W. P. M. Blom, and J. Rozema, editors. Vegetation between land and sea. Dr. W. Junk Publishers, Dordrecht.

Dijkema, K. S., A. Nicolai, J. de Vlas, C.J. Smit, H. Jongerius and H. Nauta. 2001. Van landaanwinning naar kwelderwerken. Leeuwarden, Rijkswaterstaat dir Noord-Nederland en Alterra, Research Instituut voor de groene ruimte, Texel, 68p.

Dijkema, K. S., W. E. van Duin, E. M. Dijkman, A. Nicolai, H. Jongerius, H. Keegstra En, en J. J. Jongsma. 2013. Friese en Groninger kwelderwerken. Monitoring en beheer 1960-2010. Den Burg, Texel.

Doody, J. P. 2008. Saltmarsh Conservation, Management and Restoration. Springer Netherlands, Dordrecht.

Doody, J. P. 2013. Coastal squeeze and managed realignment in southeast England, does it tell us anything about the future? Ocean \& Coastal Management 79:34-41. 
van Duin, W. E., H. Jongerius, A. Nicolai, J. J. Jongsma, A. Hendriks, en C. Sonneveld. 2016. Friese en Groninger kwelderwerken: Monitoring en beheer 1960-2014. IMARES, Wageningen UR, Rapport C042/16, Den Helder.

van Duin, W. E., P. Esselink, en K. Elschot. 2019. Vastelandskwelders Waddenzee: dynamiek en diversiteit door beheer en inrichting. Artemisia- rapport 2018-01, Den Helder.

Elschot, K., T. J. Bouma, S. Temmerman, and J. P. Bakker. 2013. Effects of long-term grazing on sediment deposition and salt-marsh accretion rates. Estuarine, Coastal and Shelf Science 133:109115.

Elschot, K., J. P. Bakker, S. Temmerman, J. Van De Koppel, and T. J. Bouma. 2015. Ecosystem engineering by large grazers enhances carbon stocks in a tidal salt marsh. Marine Ecology Progress Series 537:9-21.

Elschot, K., W. Van Duin, A. V. De Groot, K. S. Dijkema, C. Sonneveld, J. T. Van Der Wal, P. De Vries, B. Brinkman, W. Molenaar, J. Krol, L. Kuiters, D. De Vries, R. Wegman, P. Slim, E. C. Koppenaal, en J. De Vlas. 2017. Chapter 4: Ontwikkeling kwelder Ameland-Oost; evaluatie bodemdalingsonderzoek 1986-2016. Wageningen Marine Reseach, Wageningen UR, Den Helder.

Esselink, P. 2000. Nature management of coastal salt marshes. Interactions between anthropogenic influences and natural dynamics. University of Groningen.

Esselink, P., D. Bos, A. P. Oost, K. S. Dijkema, R. Bakker, en R. de Jong. 2011. Verkenning afslag Eems-Dollardkwelders:79.

Esselink, P., P. Daniels, en P. Weerstand. 2012. De Hoogte van de Dollardkwelders in 2012: beschrijving van de uitgangssituatie in het kader van het kwelderherstelprogramma Groningen. Vries.

Esselink, P., B. J. Ens, G. Lagendijk, F. Mandema, S. Nolte, J. Tinbergen, R. Van Klink, M. W. De Vries, en J. P. Bakker. 2016. De invloed van beweiding op de biodiversiteit van kwelders. De Levende Natuur 117:196-202.

Esselink, P., W. E. van Duin, J. Bunje, J. Cremer, E. O. Folmer, J. Frikke, M. Glahn, A. V. de Groot, N. Hecker, U. Hellwig, K. Jensen, P. Körber, J. Petersen, and M. Stock. 2017. Salt marshes. Page in S. Kloepper and E. Al., editors. Wadden Sea Quality Status Report 2017. Common Wadden Sea Secretariat, Wilhelmshaven, Germany.

Esselink, P., W. E. van Duin, en A. Wielemaker. 2019a. Variatie op de kwelder door beweiding: een handreiking aan natuurbeheerders. Vries.

Esselink, P., Elschot, K., Tolman, M., Veenstra, W. 2019b. Monitoring Demonstratieproject Brede Groene Dijk (fase 1 en 2): vervolgmonitoring ontwateringsstelsel, kwelderafslag, opslibbing en vegetatie (2018). PUCCIMAR rapport 18. PUCCIMAR Ecologisch Onderzoek \& Advies, Vries.

FitzGerald, D. M., M. S. Fenster, B. A. Argow, and I. V. Buynevich. 2008. Coastal Impacts Due to SeaLevel Rise. Annual Review of Earth and Planetary Sciences 36:601-647.

de Groot, A. V., R. M. Veeneklaas, D. P. J. Kuijper, and J. P. Bakker. 2011. Spatial patterns in accretion on barrier-island salt marshes. Geomorphology 134:280-296.

de Groot, A. V., A. P. Oost, R. M. Veeneklaas, E. J. Lammerts, W. E. van Duin, and B. K. van Wesenbeeck. 2017. Tales of island tails: biogeomorphic development and management of barrier islands. Journal of Coastal Conservation 21:409-419.

Hootsmans, M. J. M., J. E. Vermaat, and W. Van Vierssen. 1987. Seed-bank development, germination and early seedling survival of two seagrass species from The Netherlands: Zostera marina L. and Zostera noltii hornem. Aquatic Botany 28:275-285.

Houwing, E. J. 2000. Morphodynamic development of intertidal mudflats: Consequences for the extension of the pioneer zone. Continental Shelf Research 20:1735-1748.

Howison, R. A., H. Olff, J. van de Koppel, and C. Smit. 2017. Biotically driven vegetation mosaics in grazing ecosystems: the battle between bioturbation and biocompaction. Ecological Monographs 87:363-378.

Jong, D., K. Dijkema, J. Bossinade, and J. Jansen. 1998. SALT97. Een classificatie-programma voor kweldervegetaties. Middelburg.

Kamps, L. F. 1956. Slibhuishouding en landaanwinning in het oostelijk Waddengebied. Rijkswaterstaat Directie Landaanwinning., Baflo. 93p. 
van Katwijk, M. M., and D. C. R. Hermus. 2000. Effects of water dynamics on Zostera marina: Transplantation experiments in the intertidal Dutch Wadden Sea. Marine Ecology Progress Series 208:107-118.

van Katwijk, M. M., and L. J. M. Wijgergangs. 2004. Effects of locally varying exposure, sediment type and low-tide water cover on Zostera marina recruitment from seed. Aquatic Botany 80:1-12.

van Katwijk, M. M., A. R. Bos, V. N. de Jonge, L. S. A. M. Hanssen, D. C. R. Hermus, D. J. de Jong. 2009. Guidlines for seagrass restoration: Importance of habitat selection and donor populations, spreading of risks, and ecosystem engineering effects. Marine Pollution Bulletin 58: 179-188.

Kers, B. 2008. SALT08 classificatieprogramma voor kweldervegetaties.

Kirwan, M. L., G. R. Guntenspergen, A. D'Alpaos, J. T. Morris, S. M. Mudd, and S. Temmerman. 2010. Limits on the adaptability of coastal marshes to rising sea level. Geophysical Research Letters 37:1-5.

Kirwan, M. L., and G. R. Guntenspergen. 2012. Feedbacks between inundation, root production, and shoot growth in a rapidly submerging brackish marsh. Journal of Ecology 100:764-770.

van Klink, R., S. Nolte, F. S. Mandema, D. D. G. Lagendijk, M. F. WallisDeVries, J. P. Bakker, P. Esselink, and C. Smit. 2016. Effects of grazing management on biodiversity across trophic levelsThe importance of livestock species and stocking density in salt marshes. Agriculture, Ecosystems and Environment 235:329-339.

Kuijper, D. P. J., P. Beek, S. E. van Wieren, and J. P. Bakker. 2008. Time-scale effects in the interaction between a large and a small herbivore. Basic and Applied Ecology 9:126-134.

Londo, G. 1976. The decimal scale for releves of permanent quadrats. Vegetatio 33:61-64.

van Loon-Steensma, J. M., and P. Vellinga. 2013. Trade-offs between biodiversity and flood protection services of coastal salt marshes. Current Opinion in Environmental Sustainability 5:320-326.

McLeod, E., G. L. Chmura, S. Bouillon, R. Salm, M. Björk, C. M. Duarte, C. E. Lovelock, W. H. Schlesinger, and B. R. Silliman. 2011. A blueprint for blue carbon: Toward an improved understanding of the role of vegetated coastal habitats in sequestering CO2. Frontiers in Ecology and the Environment 9:552-560.

Michaelis, H. 2008. Langzeitstudie zur entwickeling von höhenlage, sediment, vegetation und bodenfauna in Landgewinnungsfeldern. Nordeney.

Mudd, S. M., A. D'Alpaos, and J. T. Morris. 2010. How does vegetation affect sedimentation on tidal marshes? Investigating particle capture and hydrodynamic controls on biologically mediated sedimentation. Journal of Geophysical Research: Earth Surface 115:1-14.

Neumeier, U., and C. L. Amos. 2006. The influence of vegetation on turbulence and flow velocities in European salt-marshes. Sedimentology 53:259-277.

Nolte, S., E. C. Koppenaal, P. Esselink, K. S. Dijkema, M. Schuerch, A. V. de Groot, J. P. Bakker, and S. Temmerman. 2013a. Measuring sedimentation in tidal marshes: A review on methods and their applicability in biogeomorphological studies. Journal of Coastal Conservation 17:301-325.

Nolte, S., F. Müller, M. Schuerch, A. Wanner, P. Esselink, J. P. Bakker, and K. Jensen. 2013b. Does livestock grazing affect sediment deposition and accretion rates in salt marshes? Estuarine, Coastal and Shelf Science 135:296-305.

Nolte, S., C. van der Weyde, P. Esselink, C. Smit, S. E. van Wieren, and J. P. Bakker. 2017. Behaviour of horses and cattle at two stocking densities in a coastal salt marsh. Journal of Coastal Conservation 21:369-379.

Olff, H., J. De Leeuw, J. P. Bakker, R. J. Platerink, and H. J. van Wijnen. 1997. Vegetation Succession and Herbivory in a Salt Marsh: Changes Induced by Sea Level Rise and Silt Deposition Along an Elevational Gradient. The Journal of Ecology 85:799.

Oranjewoud. 2010. Beheer en inrichtingsplan. Kwelders Groninger Noordkust en Dollard.

Petersen, J., B. Kers, and M. Stock. 2014. TMAP Typology of Coastal Vegetation in the Wadden Sea Area WADDEN SEA ECOSYSTEM No. 32 - 2014. Wilhelmshaven, Germany.

Philippart, C. J. M., K. S. Dijkema, and J. Van der Meer. 1992. Wadden Sea Seagrasses: Where and why? Netherlands Institute for Sea Research Publicatio:177-191. 
Philippart, C. J. M., and K. S. Dijkema. 1995. Wax and wane of Zostera noltii Hornem. in the Dutch Wadden Sea. Aquatic Botany 49:255-268.

van Regteren, M., I. Colosimo, P. Vries, M. E. B. Puijenbroek, V. S. Freij, M. J. Baptist, and K. Elschot. 2019. Limited seed retention during winter inhibits vegetation establishment in spring, affecting lateral marsh expansion capacity. Ecology and Evolution 00:1-15.

Rickert, C., A. Fichtner, and R. van Klink. 2018. Livestock grazing disrupts plant-insect interactions on salt marshes. Insect Conservation and Diversity 11:152-161.

van Roomen, M., C. Van Turnhout, J. Blew, K. Koffijberg, S. Nagy, G. Citegetse, and R. Foppen. 2017. East Atlantic Flyway. Pages 146-147 in S. Kloepper and E. Al., editors. Wadden Sea Quality Status Report 2017. downloaded. Common Wadden Sea Secretariat, Wilhelmshaven, Germany.

Stock, M. 2011. Patterns in surface elevation change across a temperate salt marsh platform in relation to sea-level rise. Coastline Reports 17:33-48.

Temmerman, S., P. Meire, T. J. Bouma, P. M. J. Herman, T. Ysebaert, and H. J. De Vriend. 2013, December. Ecosystem-based coastal defence in the face of global change.

Tempest, J. A., I. Möller, and T. Spencer. 2015. A review of plant-flow interactions on salt marshes: the importance of vegetation structure and plant mechanical characteristics. Wiley Interdisciplinary Reviews: Water 2:669-681.

Teuchies, J., W. Vandenbruwaene, R. Carpentier, L. Bervoets, S. Temmerman, C. Wang, T. Maris, T. J. S. Cox, A. Van Braeckel, and P. Meire. 2013. Estuaries as Filters: The Role of Tidal Marshes in Trace Metal Removal. PLoS ONE 8:1-11.

Veeneklaas, R. M., K. S. Dijkema, N. Hecker, and J. P. Bakker. 2013. Spatio-temporal dynamics of the invasive plant species Elytrigia atherica on natural salt marshes. Applied Vegetation Science 16:205-216.

Vermeersen, B. L. A., A. B. A. Slangen, T. Gerkema, F. Baart, K. M. Cohen, S. Dangendorf, M. DuranMatute, T. Frederikse, A. Grinsted, M. P. Hijma, S. Jevrejeva, P. Kiden, M. Kleinherenbrink, E. W. Meijles, M. D. Palmer, R. Rietbroek, R. E. M. Riva, E. Schulz, D. C. Slobbe, M. J. R. Simpson, P. Sterlini, P. Stocchi, R. S. W. Van De Wal, and M. Van Der Wegen. 2018. Sea-level change in the Dutch Wadden Sea. Geologie and Mijnbouw/Netherlands Journal of Geosciences 97:79-127.

Vuik, V., S. N. Jonkman, B. W. Borsje, and T. Suzuki. 2016. Nature-based flood protection: The efficiency of vegetated foreshores for reducing wave loads on coastal dikes. Coastal Engineering 116:42-56.

Vuik, V., B. W. Borsje, P. W. J. M. Willemsen, and S. N. Jonkman. 2019. Salt marshes for flood risk reduction: Quantifying long-term effectiveness and life-cycle costs. Ocean and Coastal Management 171:96-110.

van der Wal, R., M. Egas, A. Van Der Veen, and J. P. Bakker. 2000. Effects of resource competition and herbivory on plant performance along a natural productivity gradient. Journal of Ecology 88:317-330.

Wanner, A., S. Suchrow, K. Kiehl, W. Meyer, N. Pohlmann, M. Stock, and K. Jensen. 2014. Scale matters: Impact of management regime on plant species richness and vegetation type diversity in Wadden Sea salt marshes. Agriculture, Ecosystems and Environment 182:69-79.

Whitfield, A. K. 2017. The role of seagrass meadows, mangrove forests, salt marshes and reed beds as nursery areas and food sources for fishes in estuaries. Reviews in Fish Biology and Fisheries 27:75-110.

van Wijnen, H. J., and J. P. Bakker. 2001. Long-term surface elevation change in salt marshes: $A$ prediction of marsh response to future sea-level rise. Estuarine, Coastal and Shelf Science 52:381390. 


\section{Verantwoording}

WOt-technical report: 182

Projectnummer: WOT-04-009-035.02

WMR-rapport: C023/20

Wettelijke Onderzoekstaken Natuur \& Milieu (WOT N\&M) hecht grote waarde aan de kwaliteit van onze eindproducten. Een review van de rapporten op wetenschappelijke kwaliteit door een referent maakt standaard onderdeel uit van ons kwaliteitsbeleid.

De auteurs bedanken allen voor hun bijdrage aan het tot stand komen van deze rapportage.

Akkoord Extern contactpersoon

functie: Beleidsmedewerker Natuur en Biodiversiteit

naam: Marjan Datema

datum: $\quad$ 07-04-2020

Akkoord Referent

functie: $\quad$ senior onderzoeker

naam: dr. ir. Martin Baptist

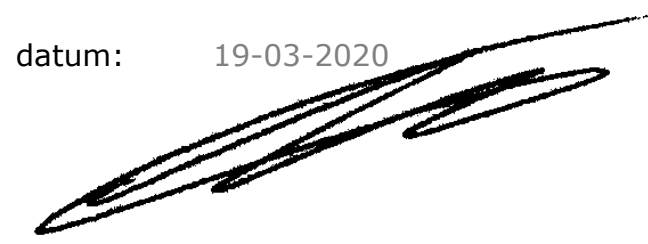

Akkoord Intern contactpersoon

naam: Anne Schmidt

datum: 20-03-2020 



\section{Bijlage 1 Monitoringsprogramma VEGWAD}

VEGWAD-monitoringsprogramma 2003-2014. Met een 6-jaarlijkse cyclus worden alle kwelders in Nederland gekarteerd.

\begin{tabular}{|c|c|c|c|c|c|c|c|c|c|c|c|c|c|c|c|c|c|c|}
\hline Deelgebied & & '04 & 5 & '06 & '07 & '08 & '09 & '10 & '11 & '12 & '13 & '14 & '15 & '16 & '17 & '18 & '19 & '20 \\
\hline Kwelders Noord-Holland & & & $\mathrm{F}$ & $\bar{U}$ & $A$ & & & & $\mathrm{~F}$ & $U$ & $A$ & & & & $\mathrm{~F}$ & $U$ & $A$ & \\
\hline Kwelder Texel & & & $\mathrm{F}$ & $u$ & $A$ & & & & $\mathrm{~F}$ & U & $A$ & & & & $\mathrm{~F}$ & $U$ & $A$ & \\
\hline Slufter Texel & & & $\mathrm{F}$ & $u$ & $A$ & & & & $\mathrm{~F}$ & $U$ & $A$ & & & & $\mathrm{~F}$ & $U$ & $A$ & \\
\hline Boschplaat Terschelling & & & & $\mathrm{F}$ & $U$ & $A$ & & & & $\mathrm{~F}$ & $U$ & $A$ & & & & $\mathrm{~F}$ & U & $A$ \\
\hline Dollard + Punt van Reide & & & & $\mathrm{F}$ & $U$ & $A$ & & & & $\mathrm{~F}$ & $u$ & $A$ & & & & $\mathrm{~F}$ & U & A \\
\hline Griend & & & & $\mathrm{F}$ & $U$ & $A$ & & & & $\mathrm{~F}$ & $U$ & $A$ & & & & $\mathrm{~F}$ & $U$ & $A$ \\
\hline $\begin{array}{l}\text { Kroonspolders (+Westerveld) } \\
\text { Vlieland } \\
\text { Noordvaarder + Groene strand } \\
\text { Terschelling }\end{array}$ & $\mathrm{F}$ & $U$ & A & & & & $\mathrm{F}$ & $\begin{array}{l}u \\
U\end{array}$ & $A$ & & & & $\begin{array}{l}F \\
F\end{array}$ & $\begin{array}{l}\mathrm{U} \\
\mathrm{U}\end{array}$ & $A$ & & & \\
\hline Oosterschelde & A & & & & $\mathrm{F}$ & $\mathrm{U}$ & A & & & & $\mathrm{F}$ & $U$ & $A$ & & & & $\mathrm{~F}$ & $\mathrm{U}$ \\
\hline Westerschelde-monding & A & & & & $\mathrm{F}$ & $U$ & $A$ & & & & $\mathrm{~F}$ & $U$ & $A$ & & & & $\mathrm{~F}$ & $\mathrm{U}$ \\
\hline Kwelderwerken GR+FR & $u$ & A & & & & $\mathrm{F}$ & $U$ & $A$ & & & & $\mathrm{~F}$ & $U$ & $A$ & & & & $\mathrm{~F}$ \\
\hline Ameland & $u$ & A & & & & $\mathrm{F}$ & $\mathrm{U}$ & $A$ & & & & $\mathrm{~F}$ & $U$ & $A$ & & & & $\mathrm{~F}$ \\
\hline Schiermonnikoog & & $\mathrm{F}$ & U & $A$ & & & & $\mathrm{~F}$ & $U$ & $A$ & & & & $\mathrm{~F}$ & $u$ & $A$ & & \\
\hline Rottum & & $\mathrm{F}$ & U & $A$ & & & & $\mathrm{~F}$ & $U$ & $A$ & & & & $\mathrm{~F}$ & $\mathrm{U}$ & $A$ & & \\
\hline Westerschelde & & $\mathrm{F}$ & $U$ & $A$ & & & & $\mathrm{~F}$ & $\mathrm{U}$ & $A$ & & & & $\mathrm{~F}$ & $\mathrm{U}$ & $A$ & & \\
\hline wade hoek) & & & & $\mathrm{F}$ & U & H & & & & $\mathrm{F}$ & $U$ & A & & & & $\mathrm{F}$ & U & A \\
\hline
\end{tabular}

$\mathrm{F}=$ fotovlucht, $\mathrm{U}=$ uitwerking, $\mathrm{A}=$ Afronding 



\section{Bijlage 2 Meetvaknummers verdeeld over provincie, deelgebied en polder van west naar oost binnen de kwelderwerken}

\begin{tabular}{|c|c|c|c|c|}
\hline Meetvaknr. & Provincie & Deelgebied & Naam & $\begin{array}{l}\text { Bloknummer } \\
\text { (damrenovatie) }\end{array}$ \\
\hline $005-008$ & Friesland & Friesland-West & Bildtpollen & \\
\hline $021-024$ & Friesland & Friesland-West & Bildtpollen & \\
\hline 041-044 & Friesland & Friesland-West & Bildtpollen & \\
\hline $053-056$ & Friesland & Friesland-West & Bildtpollen & \\
\hline 069-072 & Friesland & Friesland-Midden & Noorderleeg & $1(63 \mathrm{t} / \mathrm{m} \mathrm{186})$ \\
\hline $085-088$ & Friesland & Friesland-Midden & Noorderleeg & $1(63 \mathrm{t} / \mathrm{m} \mathrm{186})$ \\
\hline $101-104$ & Friesland & Friesland-Midden & $\begin{array}{l}\text { Blije en Ferwerd } \\
\text { Buitendijks }\end{array}$ & $1(63 \mathrm{t} / \mathrm{m} \mathrm{186})$ \\
\hline $121-124$ & Friesland & Friesland-Midden & $\begin{array}{l}\text { Blije en Ferwerd } \\
\text { Buitendijks }\end{array}$ & $1(63 \mathrm{t} / \mathrm{m} \mathrm{186})$ \\
\hline $145-148$ & Friesland & Friesland-Midden & $\begin{array}{l}\text { Blije en Ferwerd } \\
\text { Buitendijks }\end{array}$ & $1(63 \mathrm{t} / \mathrm{m} \mathrm{186})$ \\
\hline $167-171$ & Friesland & Friesland-Midden & Holwerd Buitendijks West & $1(63 \mathrm{t} / \mathrm{m} \mathrm{186})$ \\
\hline $183-186$ & Friesland & Friesland-Midden & Holwerd Buitendijks West & $1(63 \mathrm{t} / \mathrm{m} \mathrm{186})$ \\
\hline $205-208$ & Friesland & Friesland-Oost & Holwerd Buitendijks Oost & \\
\hline $260-263$ & Groningen & Groningen-West & Westpolder & $2(250$ t/m 368) \\
\hline $286-289$ & Groningen & Groningen-West & Julianapolder & $2(250$ t/m 368) \\
\hline $308-311$ & Groningen & Groningen-West & Negenboerenpolder & $2(250$ t/m 368) \\
\hline $324-327$ & Groningen & Groningen-West & Negenboerenpolder & $2(250$ t/m 368) \\
\hline $336-339$ & Groningen & Groningen-Midden & Negenboerenpolder & $2(250$ t/m 368) \\
\hline $356-359$ & Groningen & Groningen-Midden & Linthorst Homanpolder & $2(250$ t/m 368) \\
\hline $372-375$ & Groningen & Groningen-Midden & Linthorst Homanpolder & $3(369$ t/m 500) \\
\hline 392-395 & Groningen & Groningen-Midden & Linthorst Homanpolder & $3(369$ t/m 500) \\
\hline $412-415$ & Groningen & Groningen-Oost & Noordpolder & $3(369$ t/m 500) \\
\hline $428-431$ & Groningen & Groningen-Oost & Noordpolder & $3(369$ t/m 500) \\
\hline $448-451$ & Groningen & Groningen-Oost & Noordpolder & $3(369$ t/m 500) \\
\hline $468-471$ & Groningen & Groningen-Oost & Lauwerspolder & $3(369$ t/m 500) \\
\hline $488-491$ & Groningen & Groningen-Oost & Lauwerspolder & $3(369$ t/m 500) \\
\hline
\end{tabular}





\section{Bijlage 3 Opname meetvakken maaiveldhoogte en damrenovatie}

\section{Opname meetvakken maaiveldhoogte}

\begin{tabular}{|l|l|l|l|l|l|l|l|l|l|l|l|l|}
\hline Friesland & 2009 & 2010 & 2011 & 2012 & 2013 & 2014 & 2015 & 2016 & 2017 & 2018 & 2019 & 2020 \\
\hline $005-008$ & & & & & & & & & & & & \\
\hline $021-024$ & & & & & & & & & & & & \\
\hline $041-044$ & & & & & & & & & & & & \\
\hline $053-056$ & & & & & & & & & & & & \\
\hline $069-072$ & & & & & & & & & & & & \\
\hline $085-088$ & & & & & & & & & & & & \\
\hline $101-104$ & & & & & & & & & & & & \\
\hline $121-124$ & & & & & & & & & & & & \\
\hline $145-148$ & & & & & & & & & & & & \\
\hline $167-170$ & & & & & & & & & & & & \\
\hline $183-186$ & & & & & & & & & & & & \\
\hline $205-208$ & & & & & & & & & & & & \\
\hline
\end{tabular}

\begin{tabular}{|l|l|l|l|l|l|l|l|l|l|l|l|l|}
\hline Groningen & 2009 & 2010 & 2011 & 2012 & 2013 & 2014 & 2015 & 2016 & 2017 & 2018 & 2019 & 2020 \\
\hline $260-263$ & & & & & & & & & & & & \\
\hline $286-289$ & & & & & & & & & & & & \\
\hline $308-311$ & & & & & & & & & & & & \\
\hline $324-327$ & & & & & & & & & & & & \\
\hline $336-339$ & & & & & & & & & & & & \\
\hline $356-359$ & & & & & & & & & & & & \\
\hline $372-375$ & & & & & & & & & & & & \\
\hline $392-395$ & & & & & & & & & & & & \\
\hline $412-415$ & & & & & & & & & & & & \\
\hline $428-431$ & & & & & & & & & & & & \\
\hline $448-451$ & & & & & & & & & & & & \\
\hline $468-471$ & & & & & & & & & & & & \\
\hline $488-491$ & & & & & & & & & & & & \\
\hline
\end{tabular}

\section{Damrenovatie verdeeld in 6 blokken}

Friesland
\begin{tabular}{|l|c|l|l|l|l|l|l|l|l|l|l|l|l|}
\hline Blok & Dam-nummer & 2009 & 2010 & 2011 & 2012 & 2013 & 2014 & 2015 & 2016 & 2017 & 2018 & 2019 & 2020 \\
\hline 3 & $63 \mathrm{t} / \mathrm{m} \mathrm{140}$ & & & & & & & & & & & & \\
\hline 5 & $141 \mathrm{t} / \mathrm{m} \mathrm{186}$ & & & & & & & & & & & & \\
\hline
\end{tabular}

Groningen
\begin{tabular}{|l|l|l|l|l|l|l|l|l|l|l|l|l|l|}
\hline Blok & Damnummer & 2009 & 2010 & 2011 & 2012 & 2013 & 2014 & 2015 & 2016 & 2017 & 2018 & 2019 & 2020 \\
\hline 4 & $250 \mathrm{t} / \mathrm{m} 315$ & & & & & & & & & & & & \\
\hline 1 & $316 \mathrm{t} / \mathrm{m} \mathrm{368}$ & & & & & & & & & & & & \\
\hline 2 & $369 \mathrm{t} / \mathrm{m} \mathrm{420}$ & & & & & & & & & & & & \\
\hline 6 & $421 \mathrm{t} / \mathrm{m} \mathrm{500}$ & & & & & & & & & & & & \\
\hline
\end{tabular}





\section{Bijlage 4 Terugtrekken van de vegetatiegrens richting dijk voorbij de 'afgepaalde' kweldergrens}

A) Langs de Westpolder (meetvakken 260-271, Groningen-West).

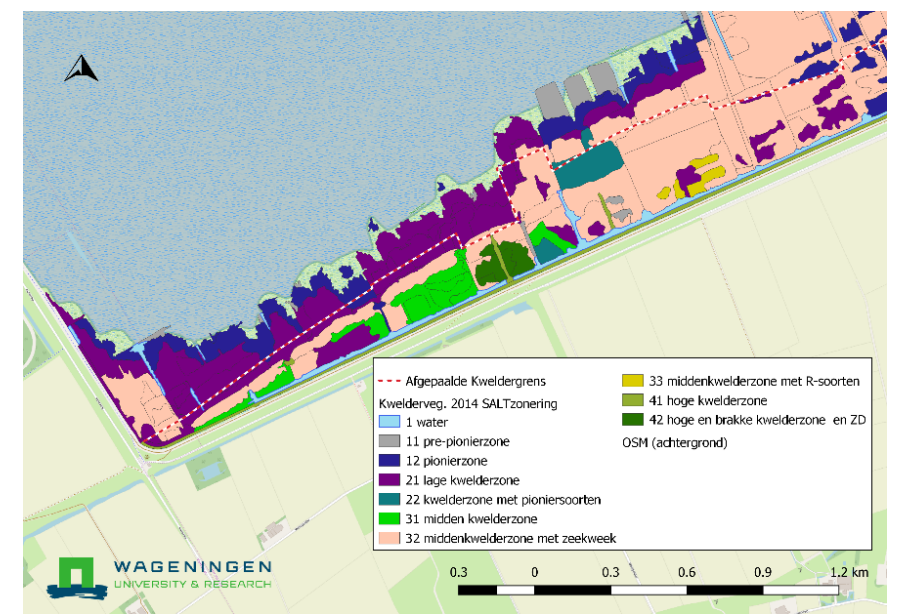

B) NW-hoek Linthorst-Homanpolder (meetvakken 349-355, Groningen-Midden).

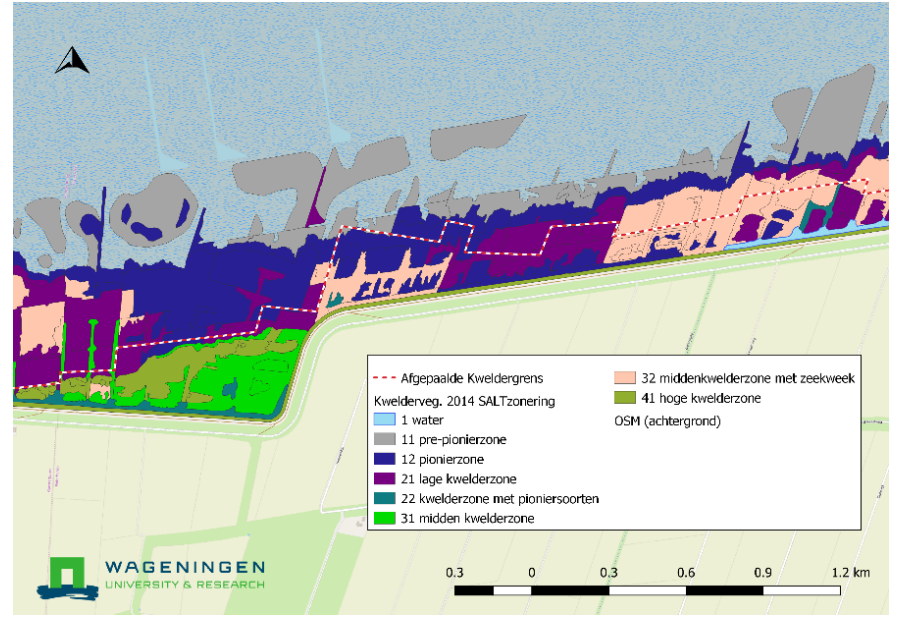

C) Midden van Linthorst-Homanpolder (meetvakken 373-374, Groningen-Midden).

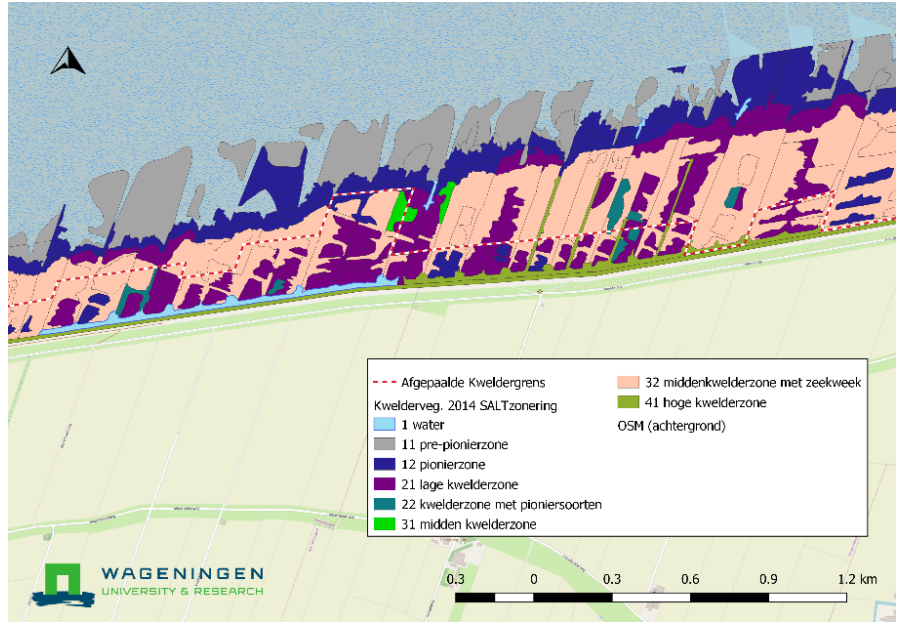





\section{Bijlage 5 Visuele weergave van de veranderingen in de kweldervegetatie tussen 1960 en 2018 per meetvak}


Friesland West: 5 - 8 (Bildtpollen)
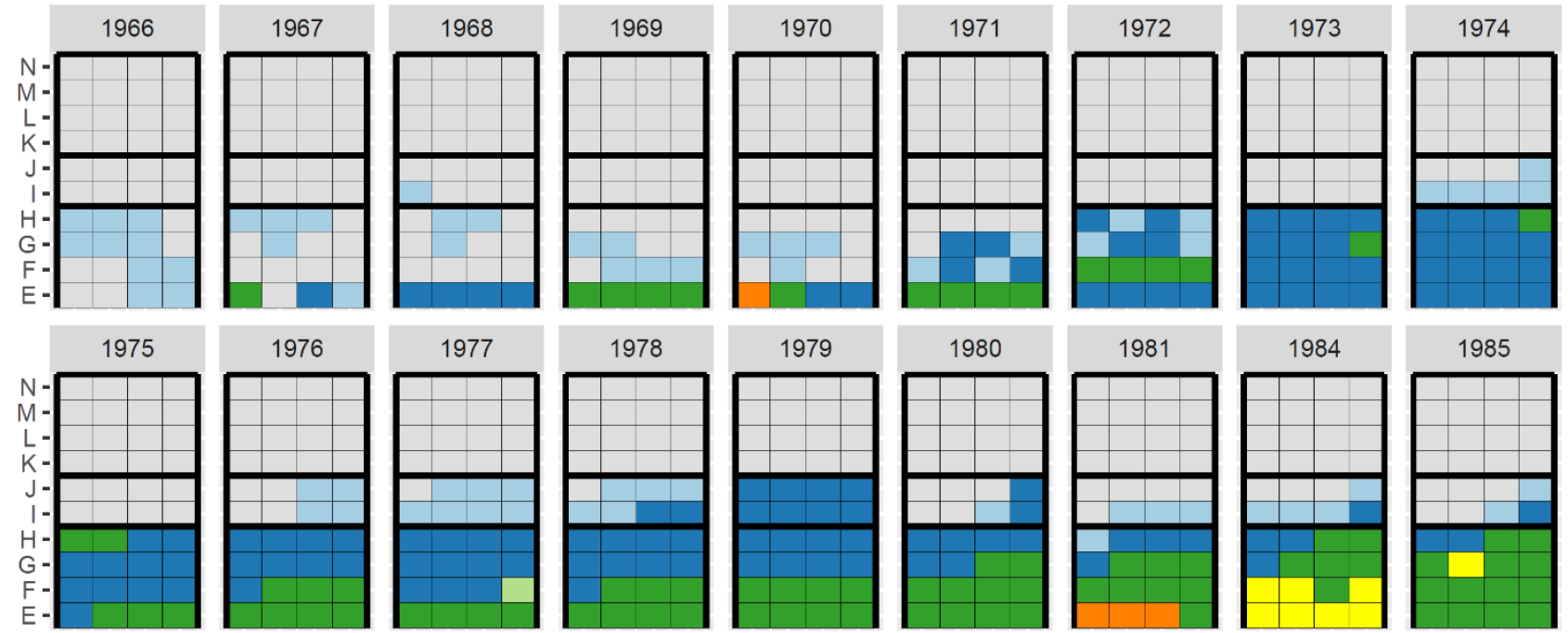

1985
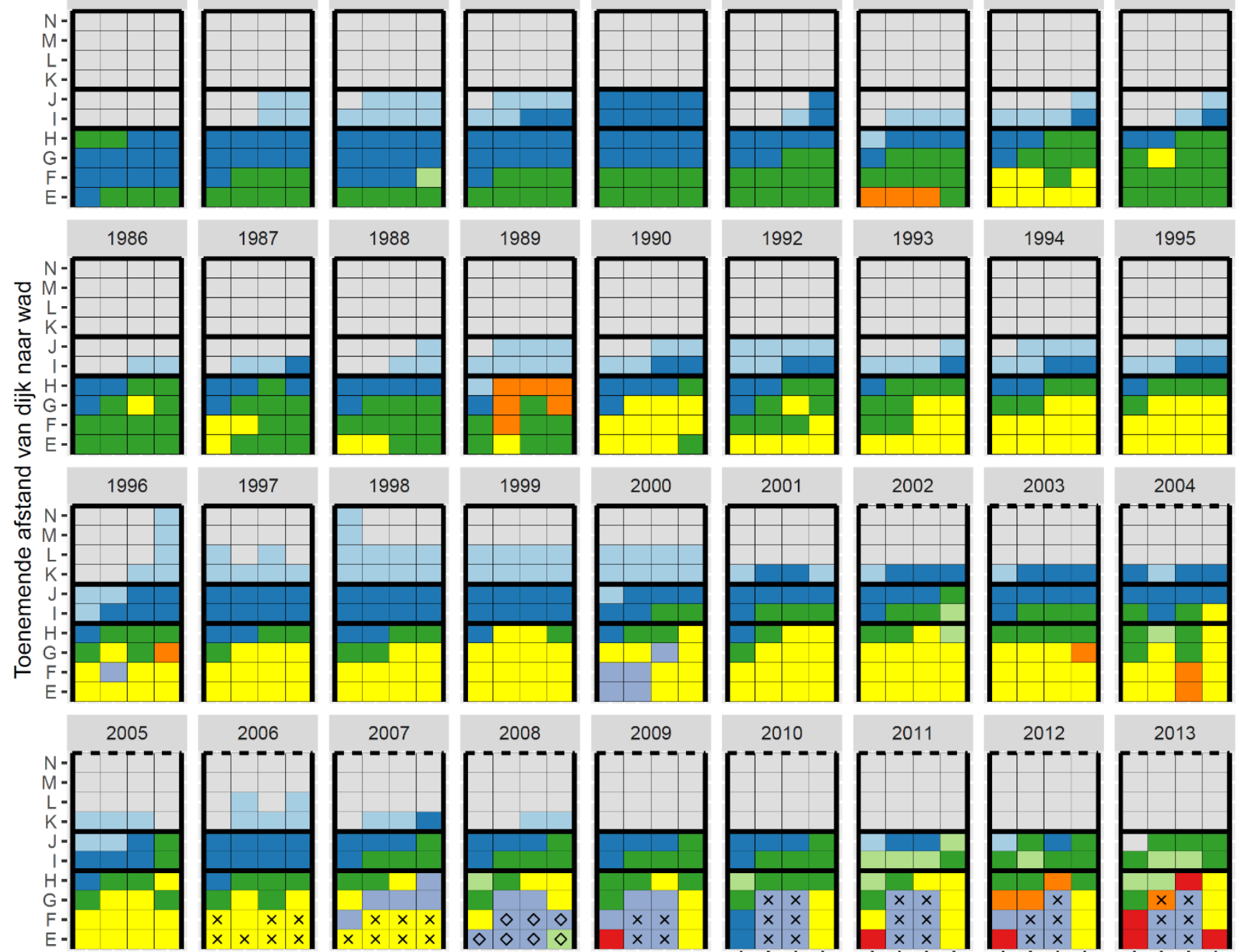

2007
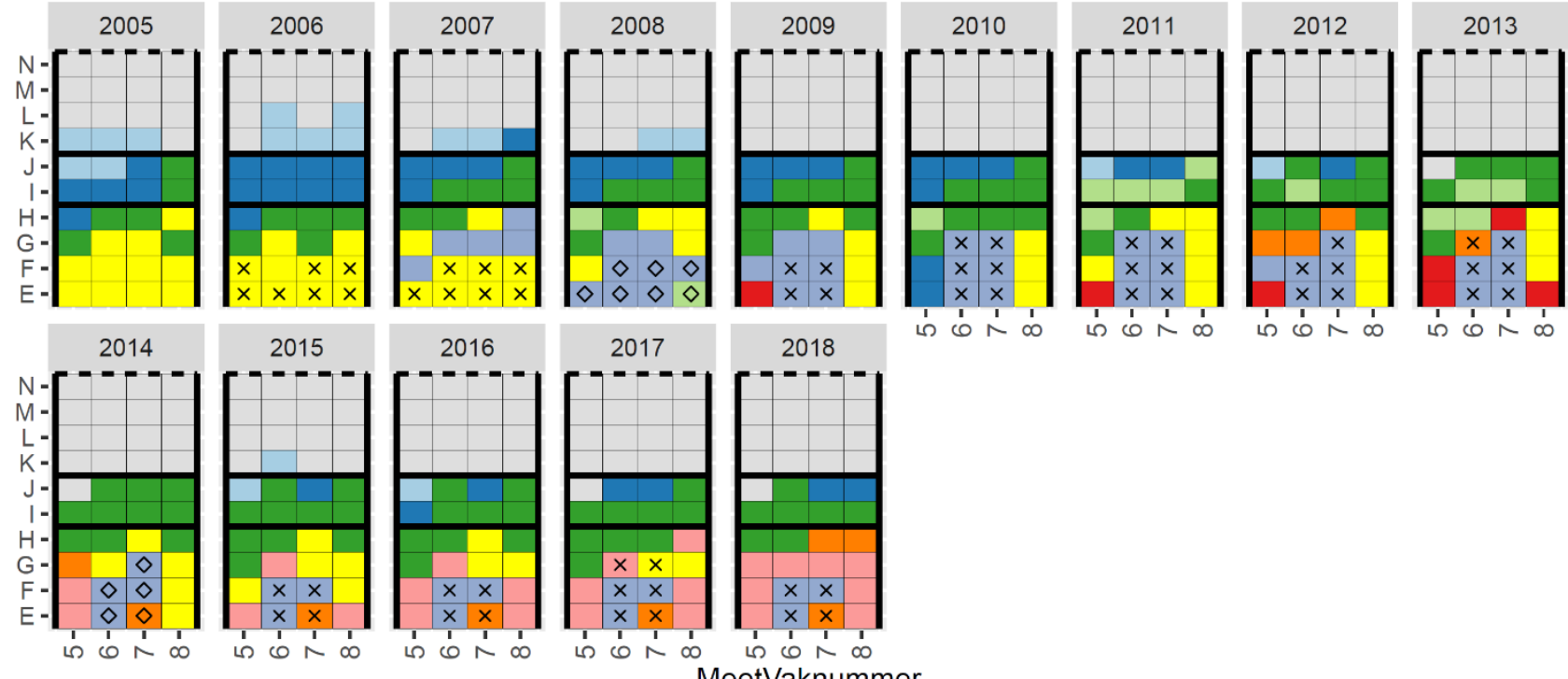

MeetVaknummer

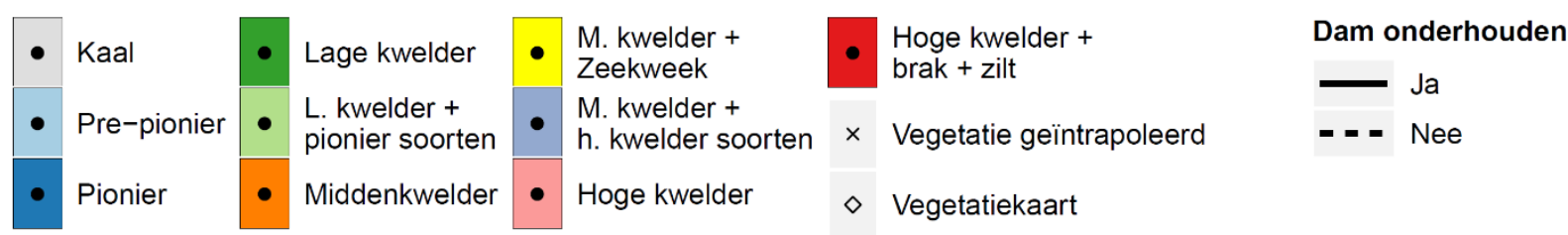


Friesland West: 21 - 24 (Bildtpollen)
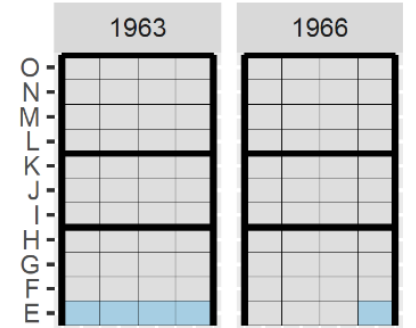

1967

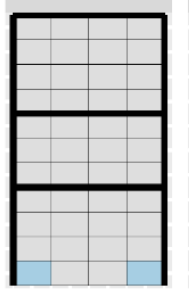

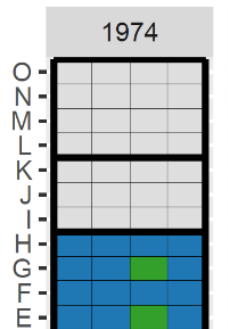

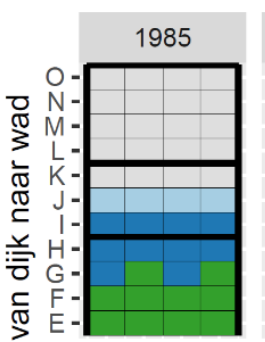

1986

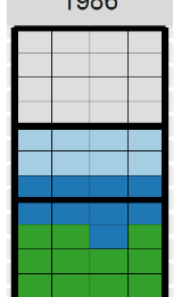

당

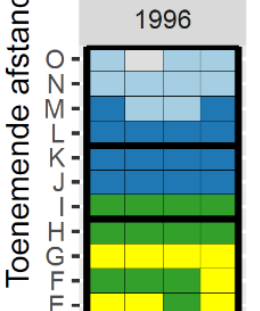

1997
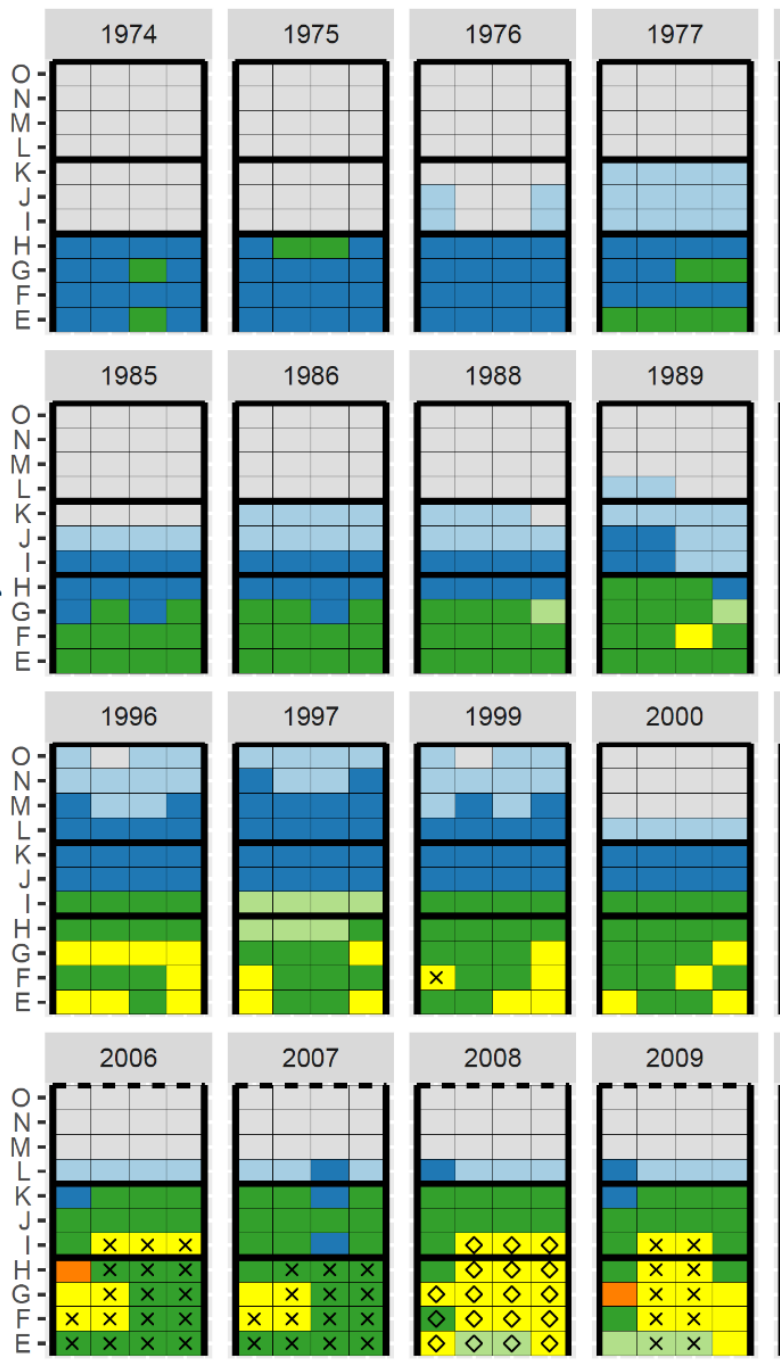
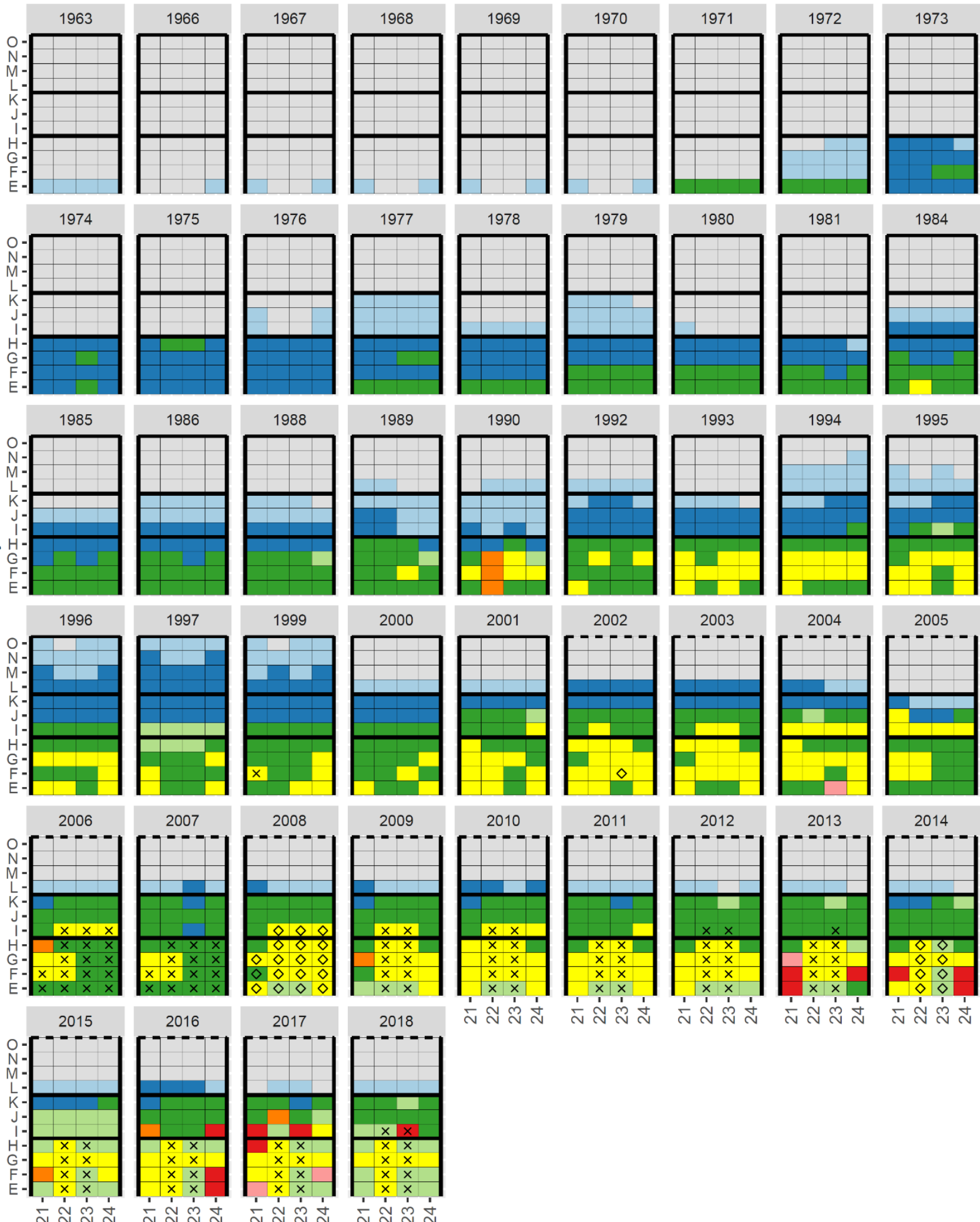

MeetVaknummer

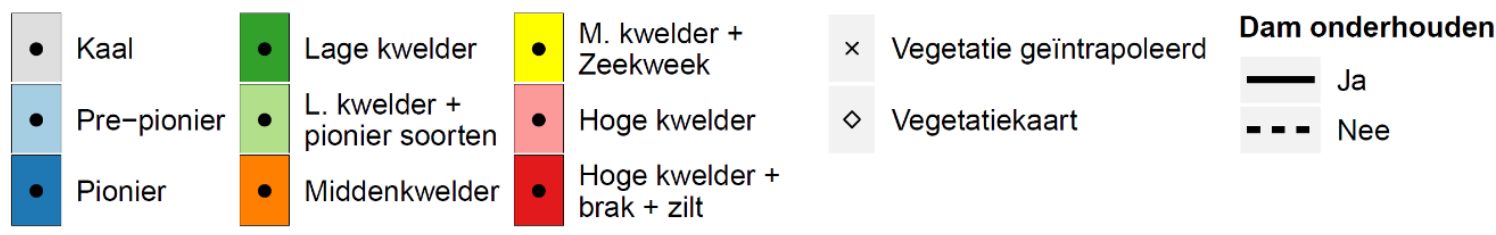


Friesland West: 41 - 44 (Bildtpollen)
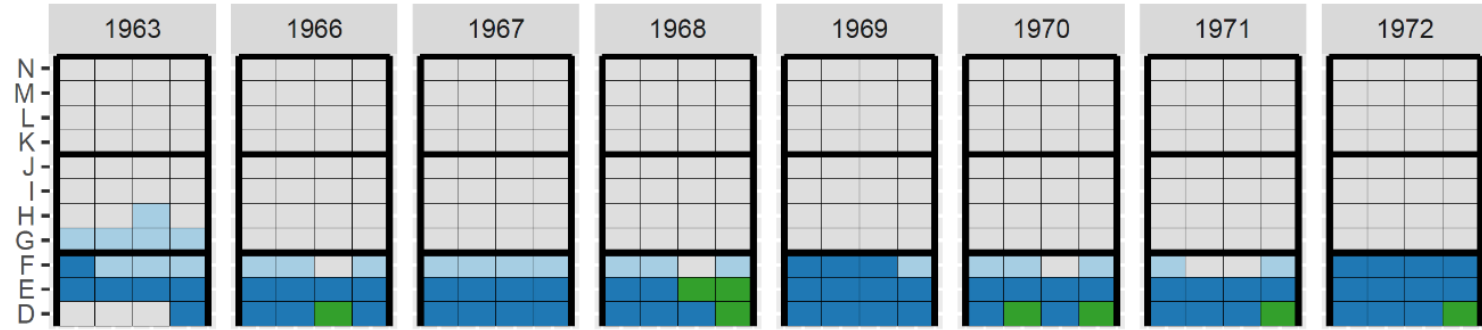

1973
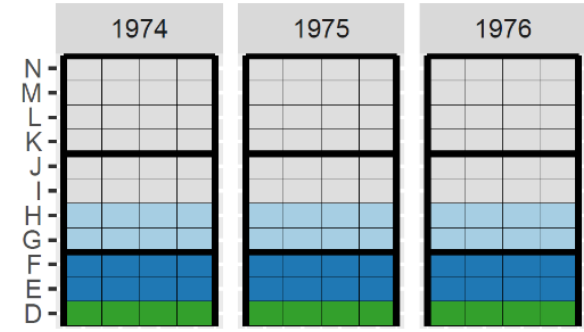

1977

1978

1979

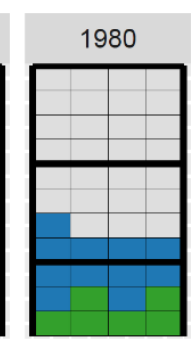

1981
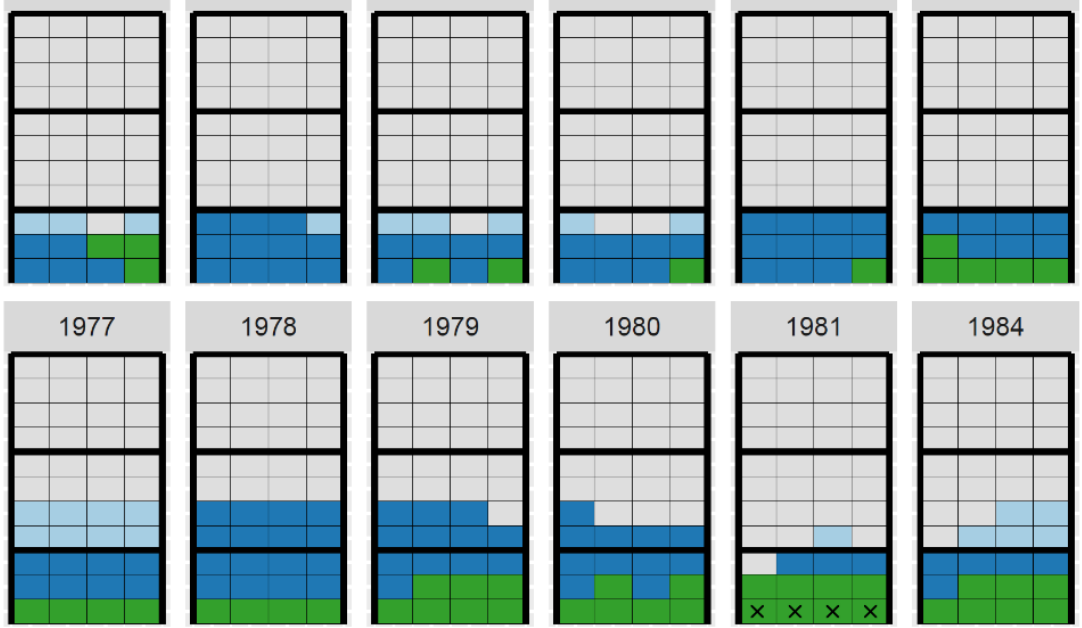

1984

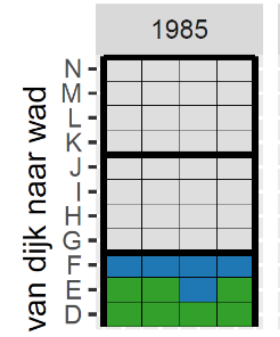

1986

1987

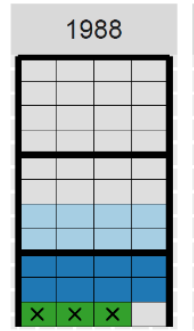

1989

1990
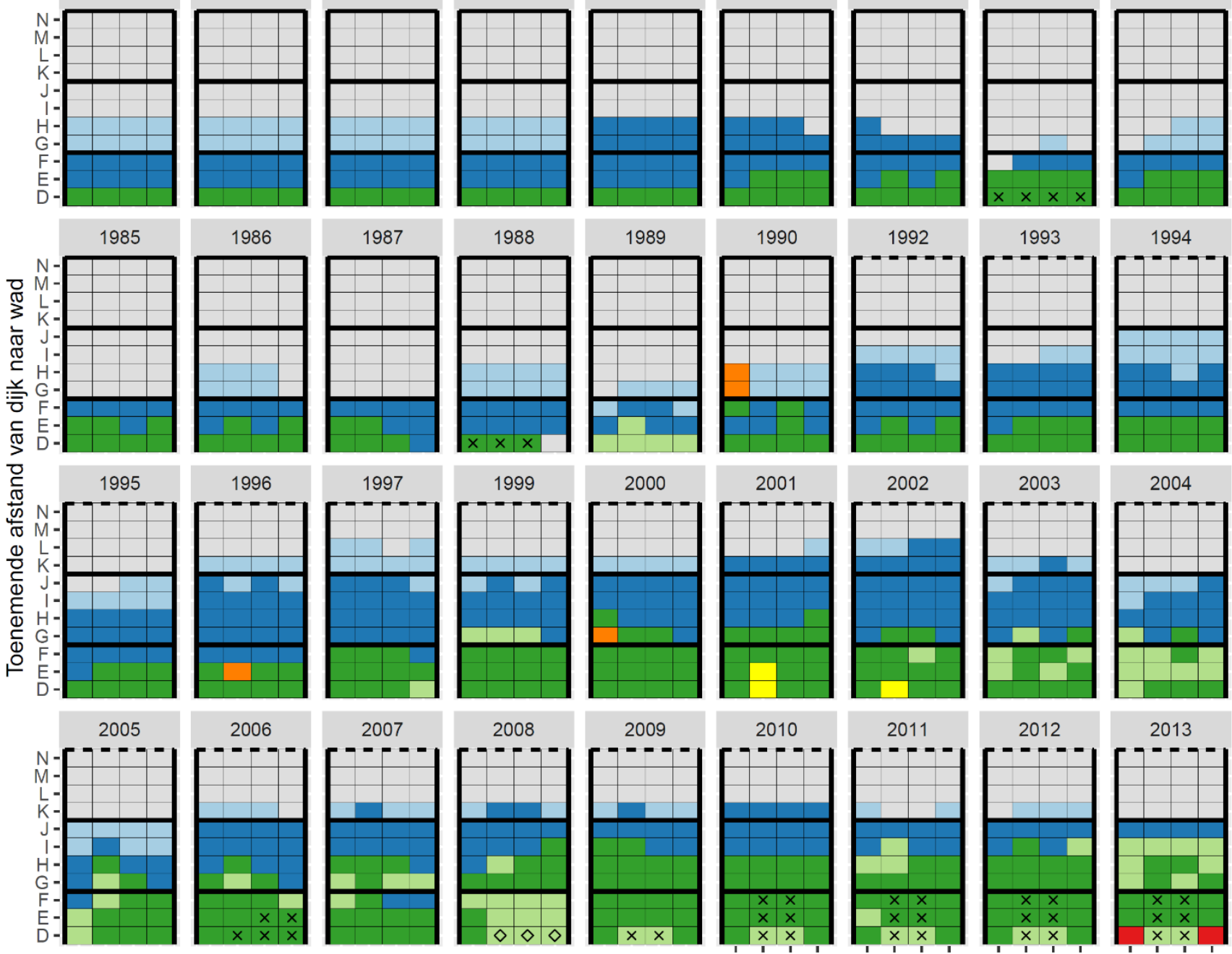

2006
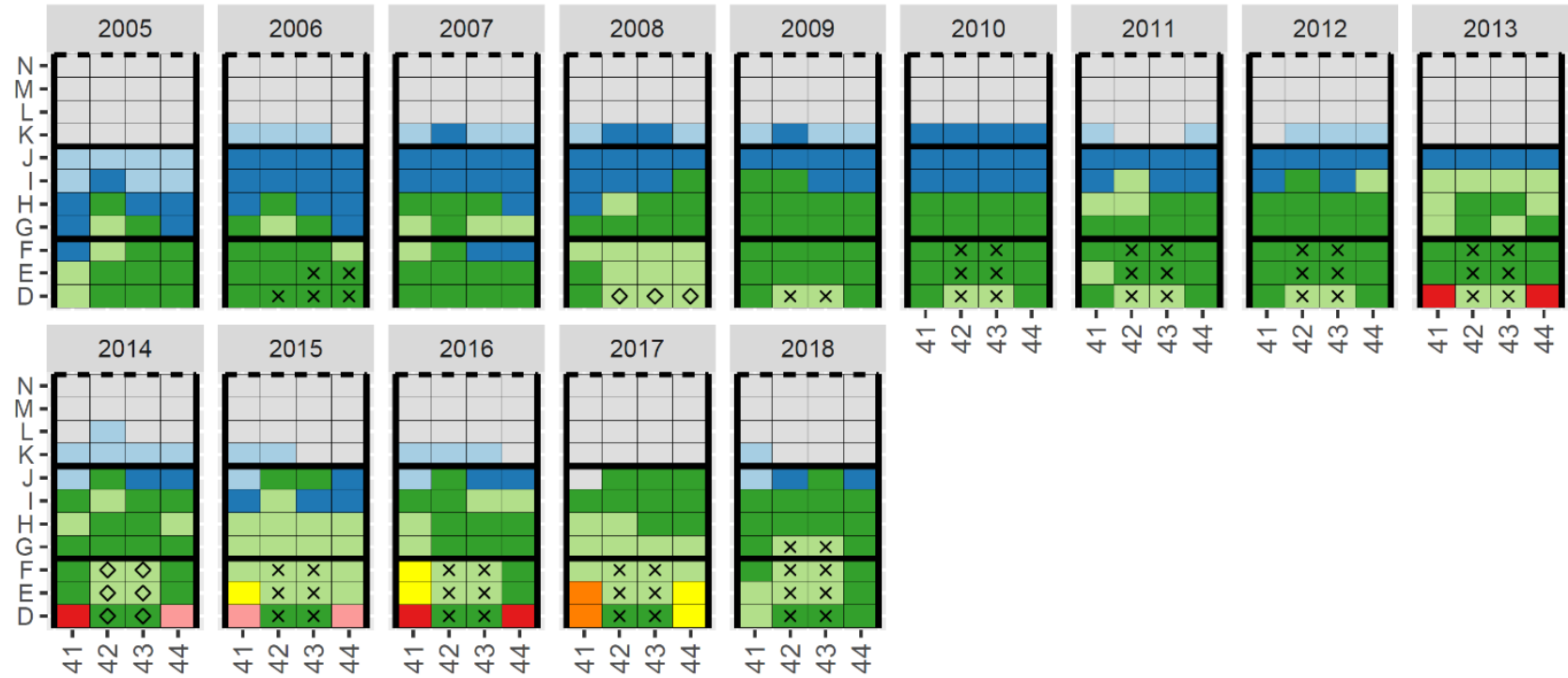

2015 2016

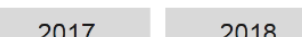

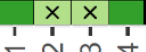

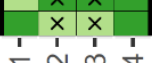

2018
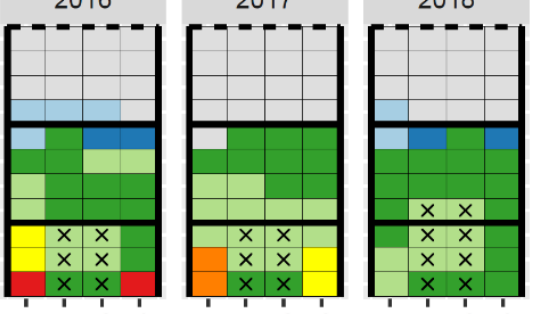

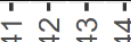

MeetVaknummer

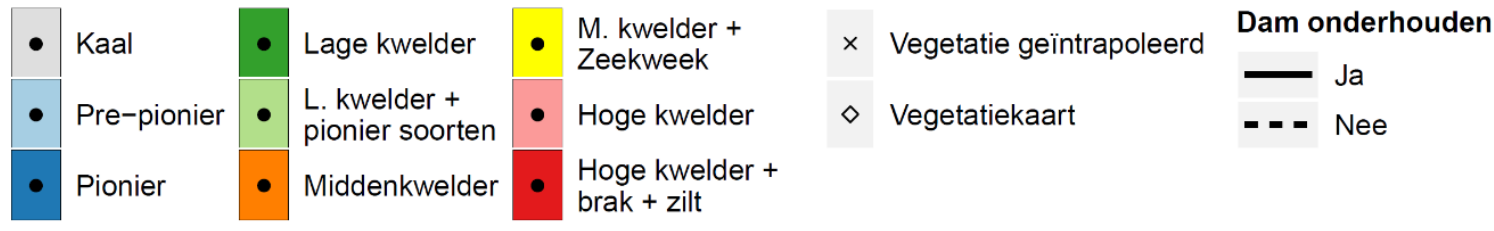


Friesland West: 53 - 56 (Bildtpollen)
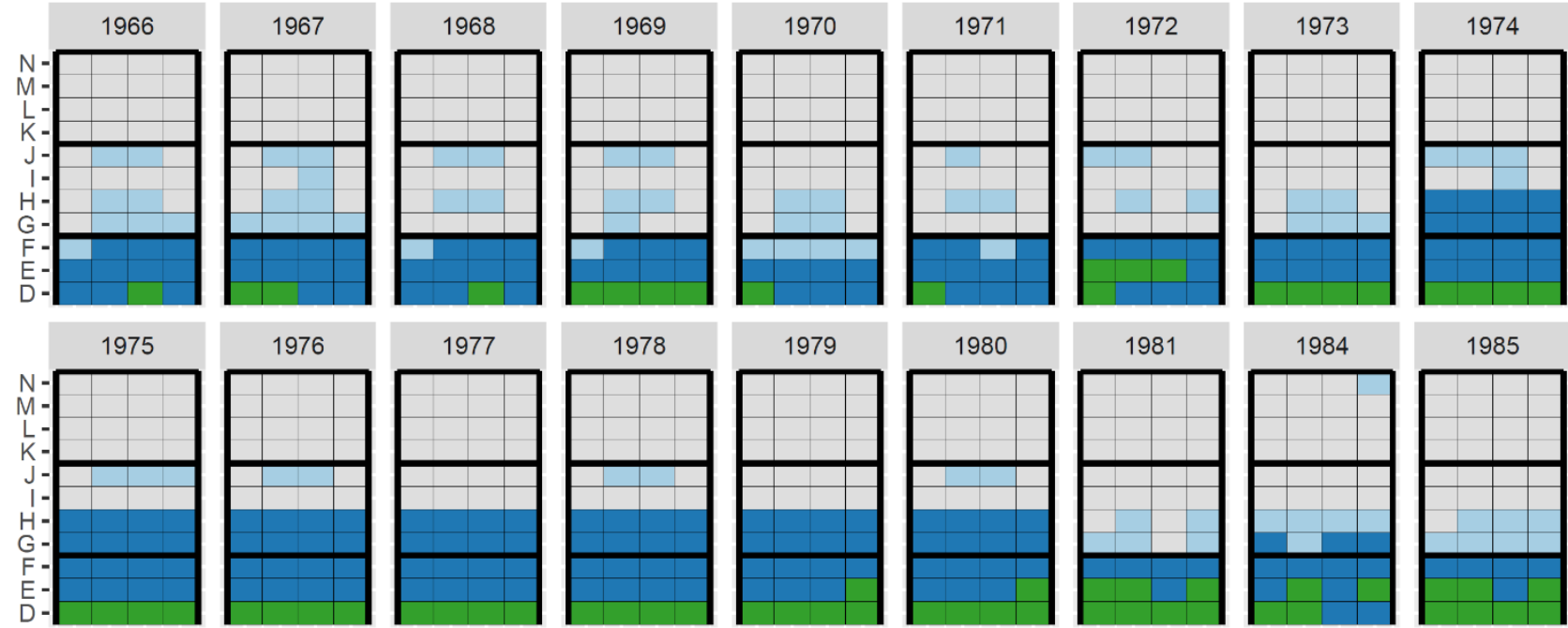

$$
1976
$$

1977

1978

1979

1980

1981

1984

1985
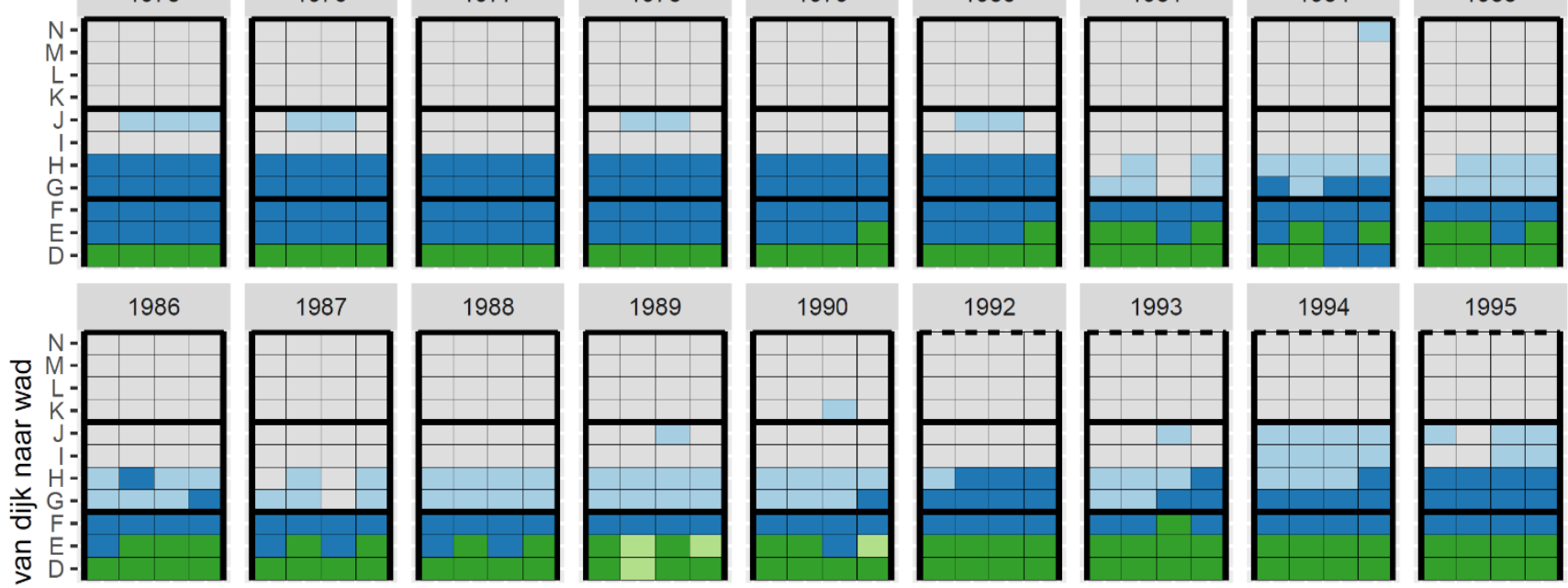

1987

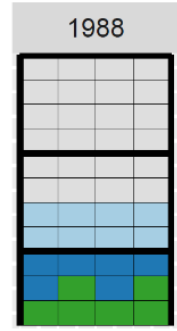

1989
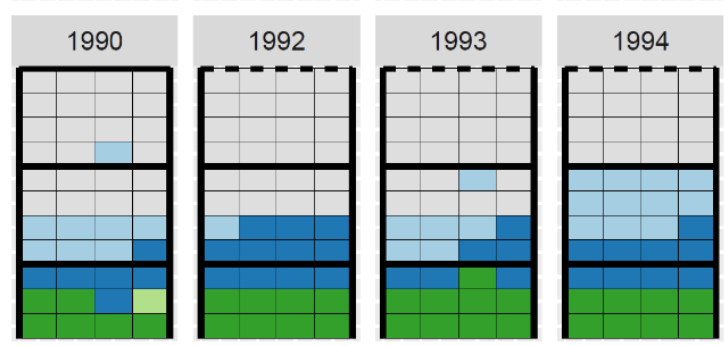

1995
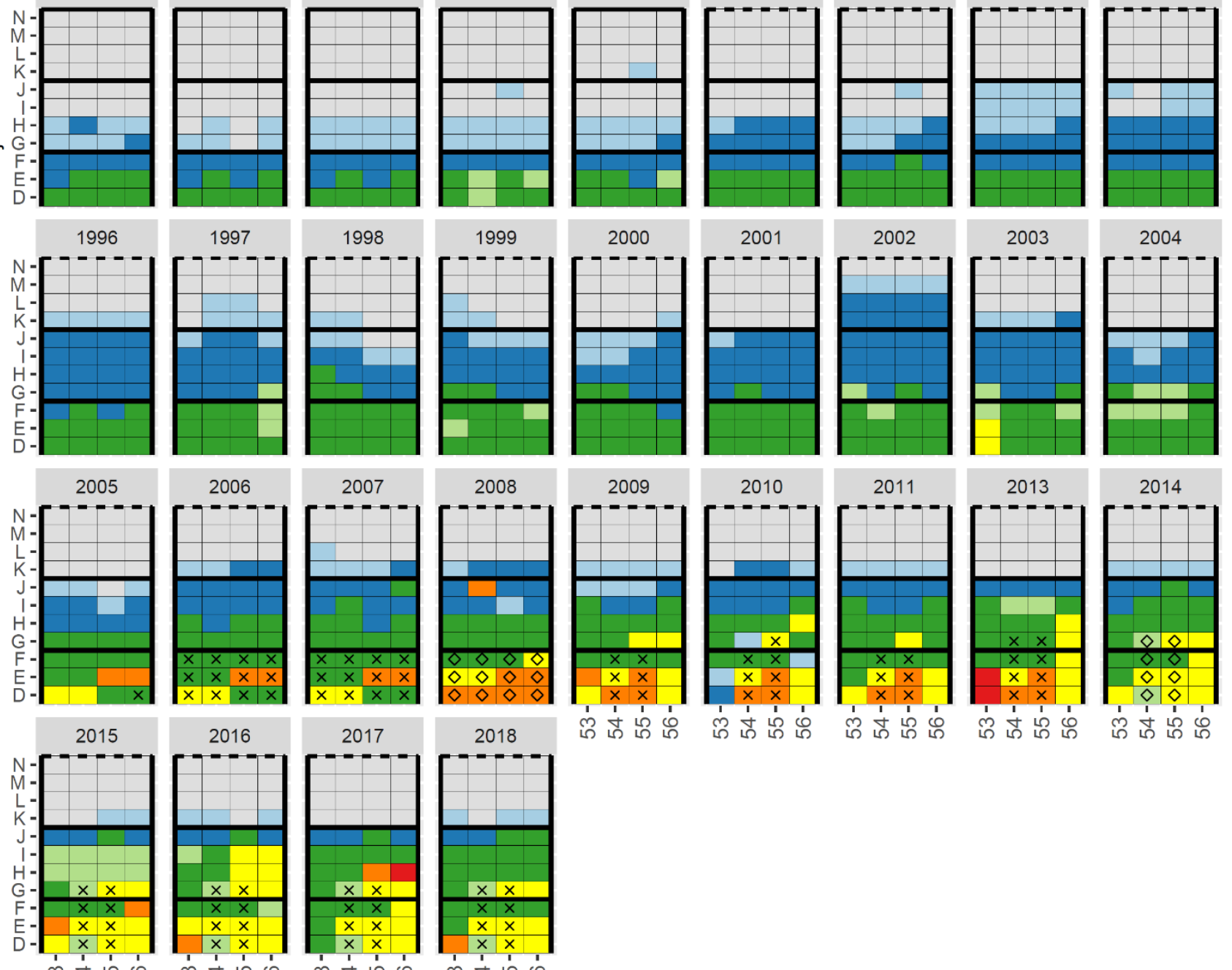

2017

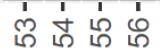

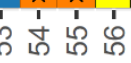

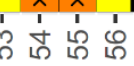

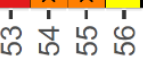

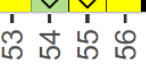

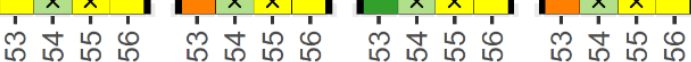

MeetVaknummer

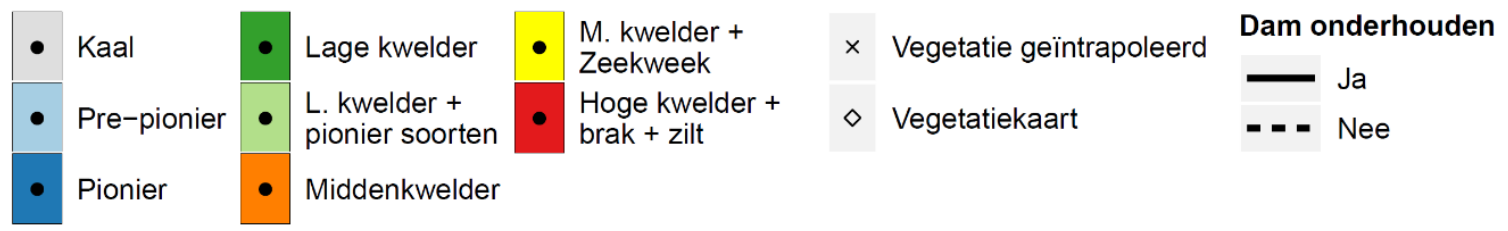


Friesland Midden: 69 - 72 (Noorderleeg)
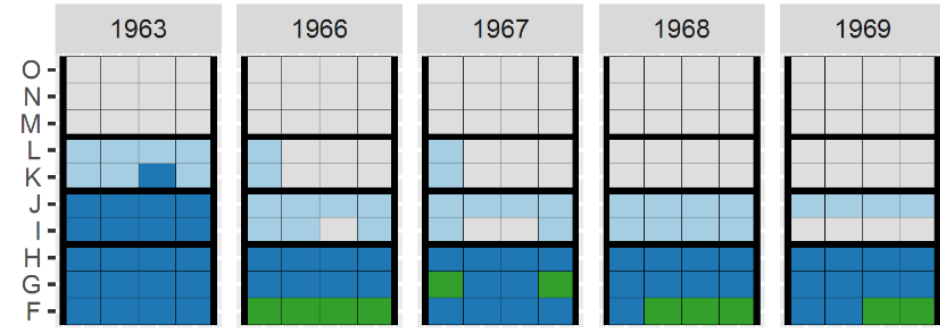

1970

1971

1972

1973

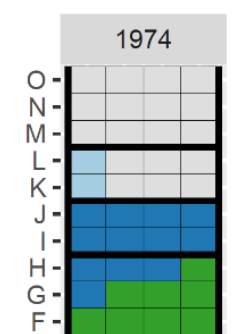

1975

1976

1977

1978
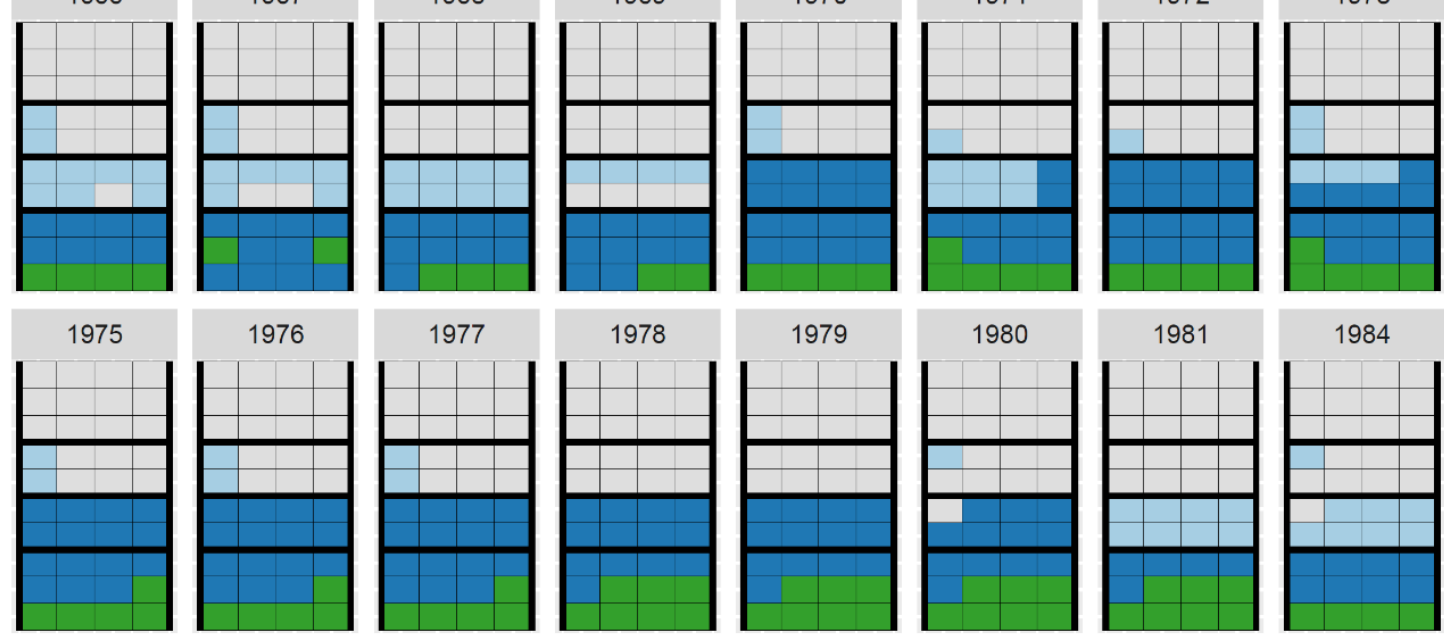

1979

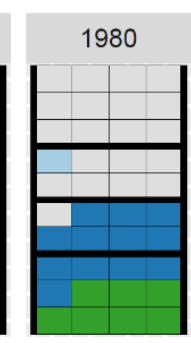

1981

1984

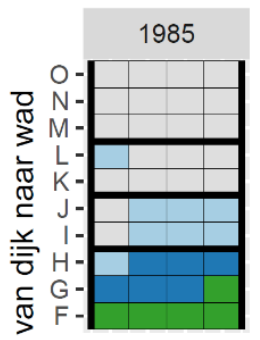

1986

1987

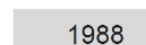

1989

1990

1992
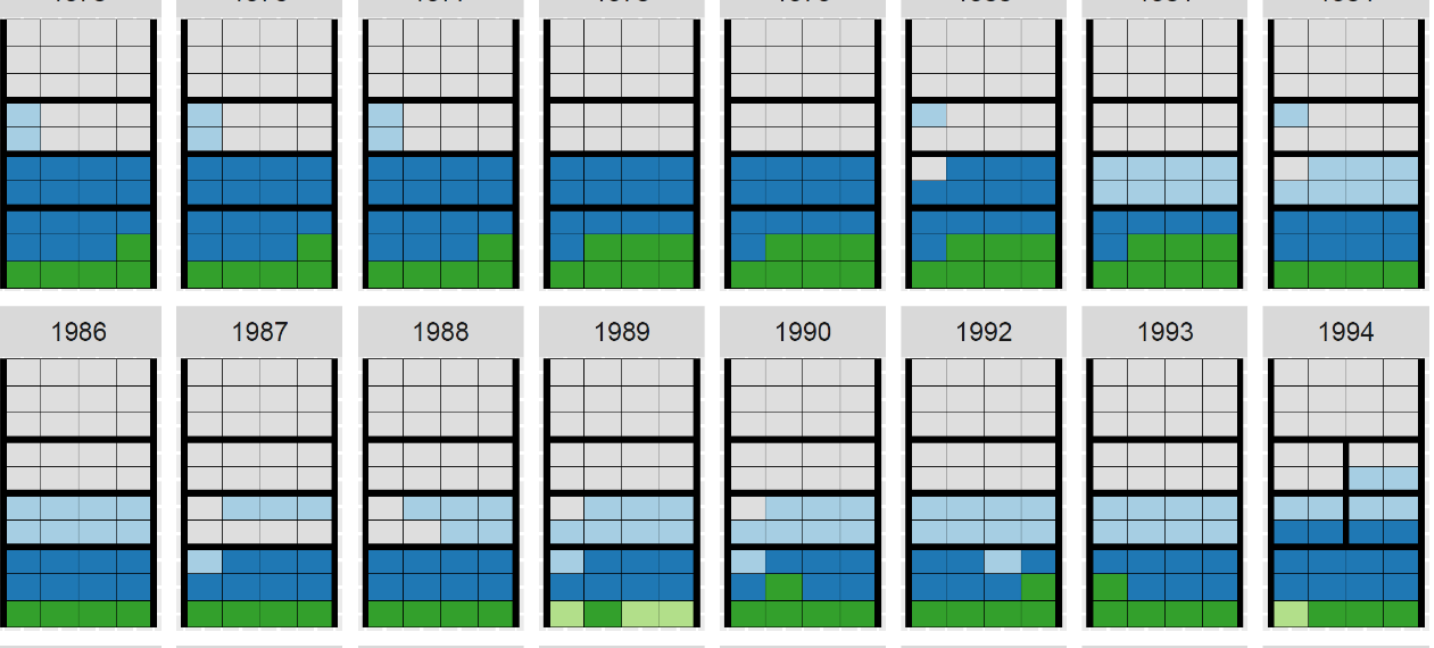

1994
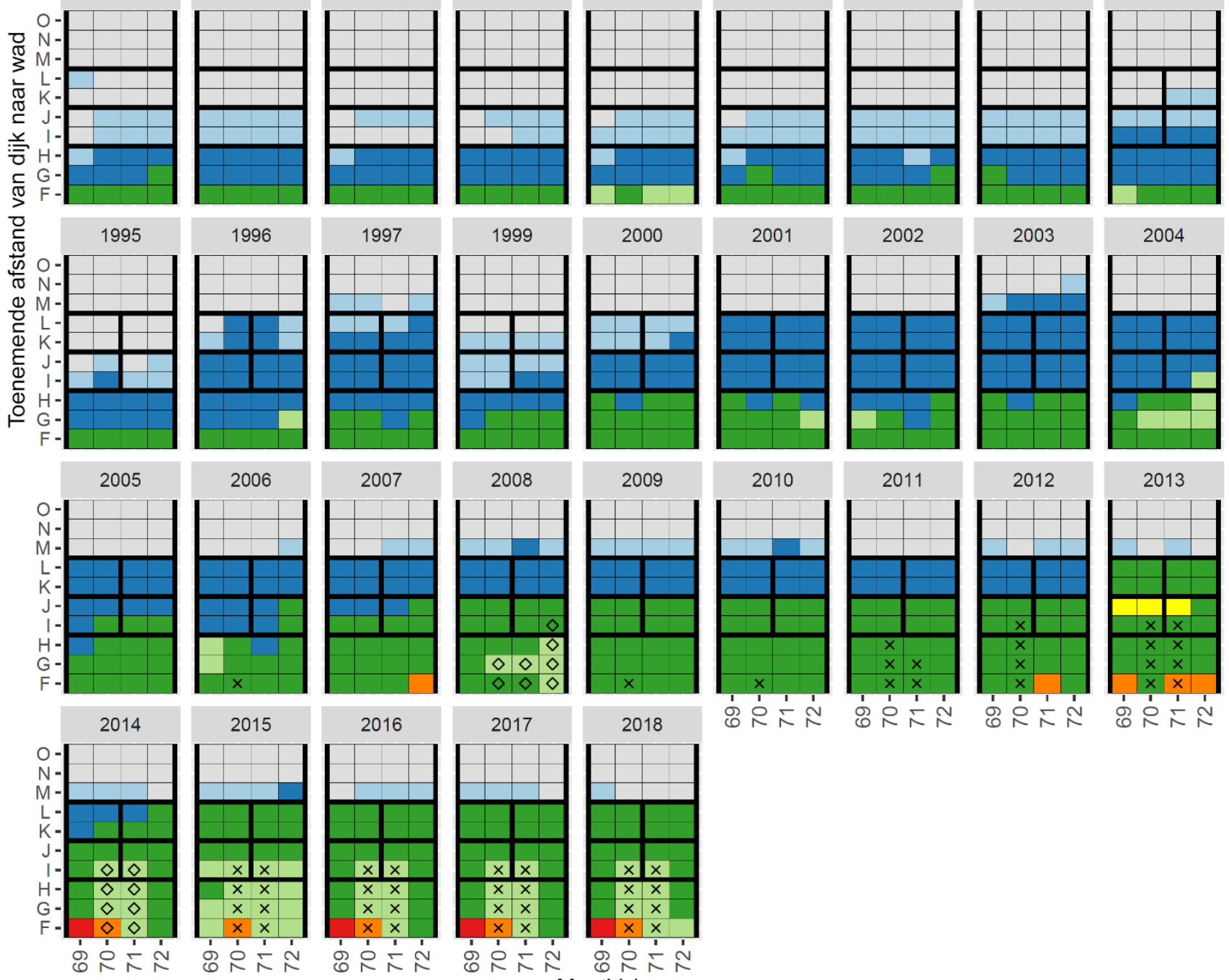

करำ

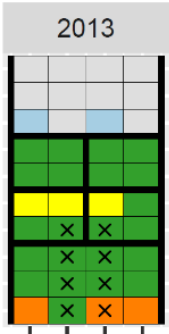

\footnotetext{
MeetVaknummer
}

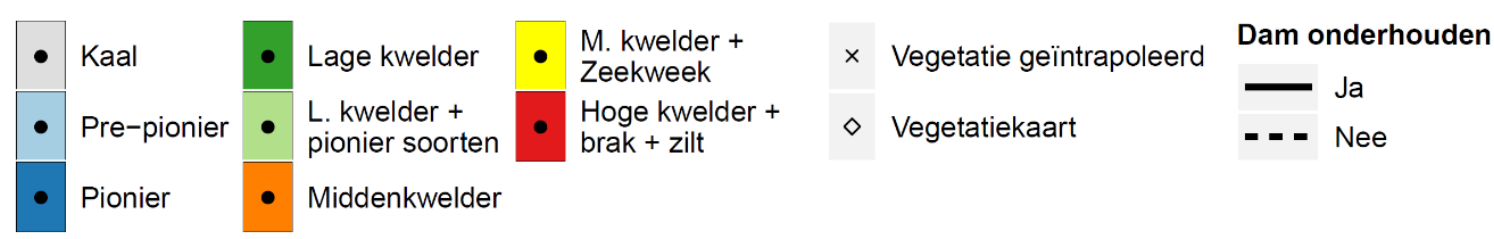


Friesland Midden: 85 - 88 (Noorderleeg)
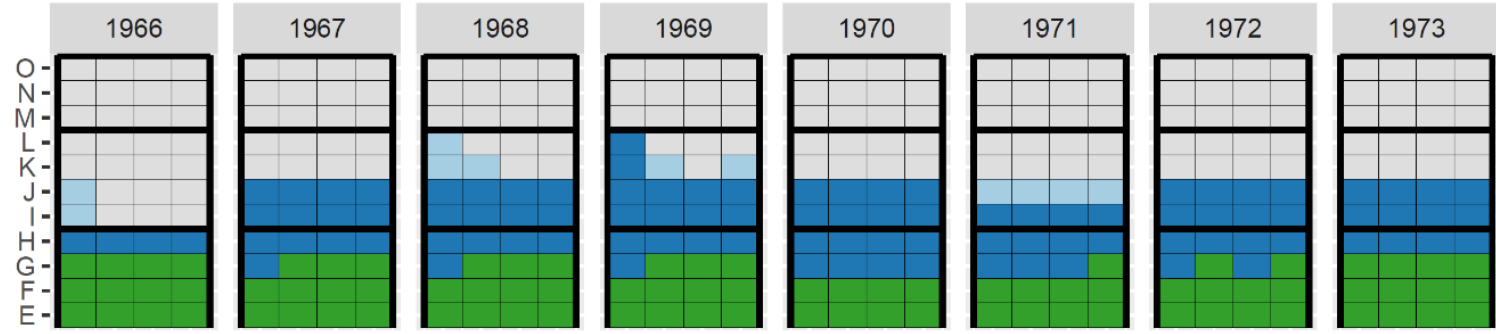

1974
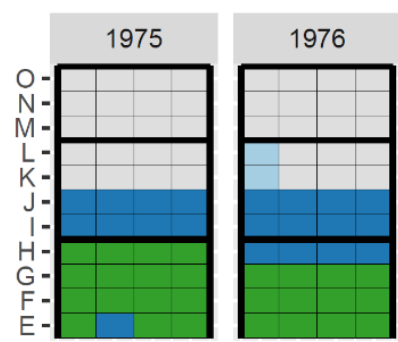

1977

1978
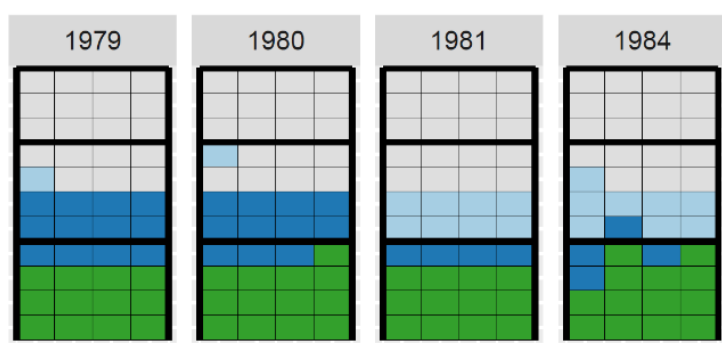

1985

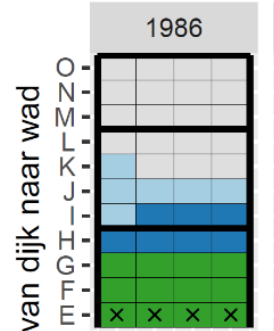

1987
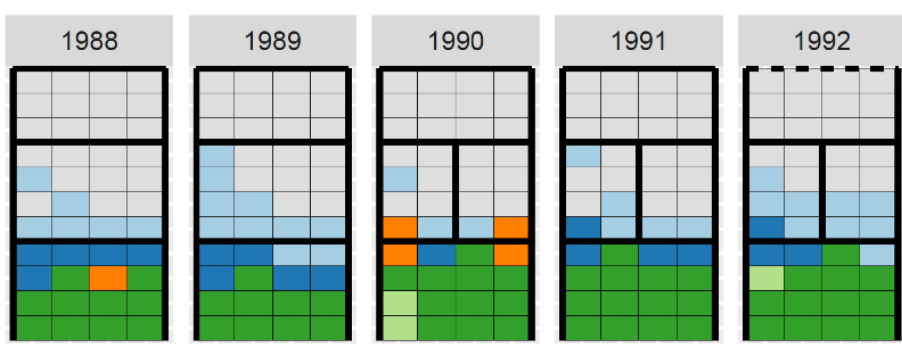

1993
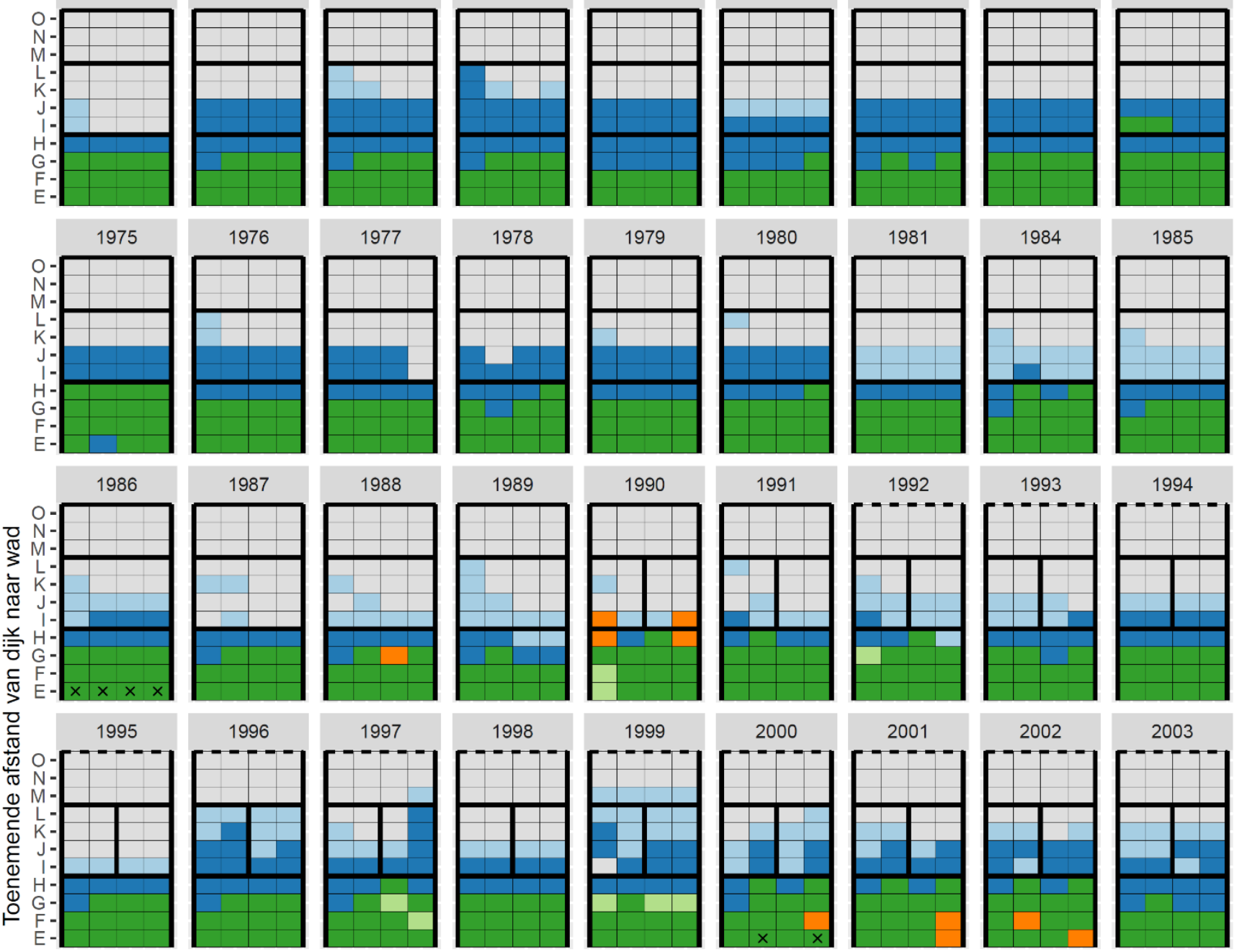

2000
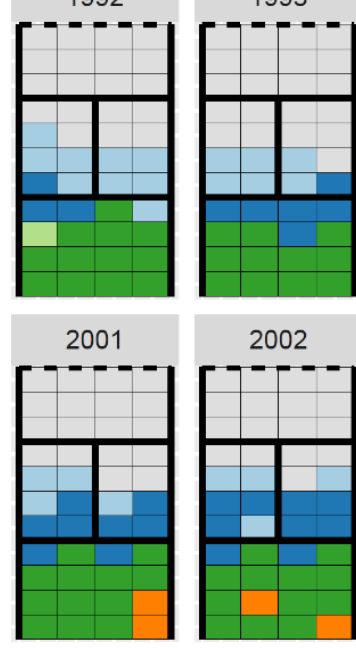

1994
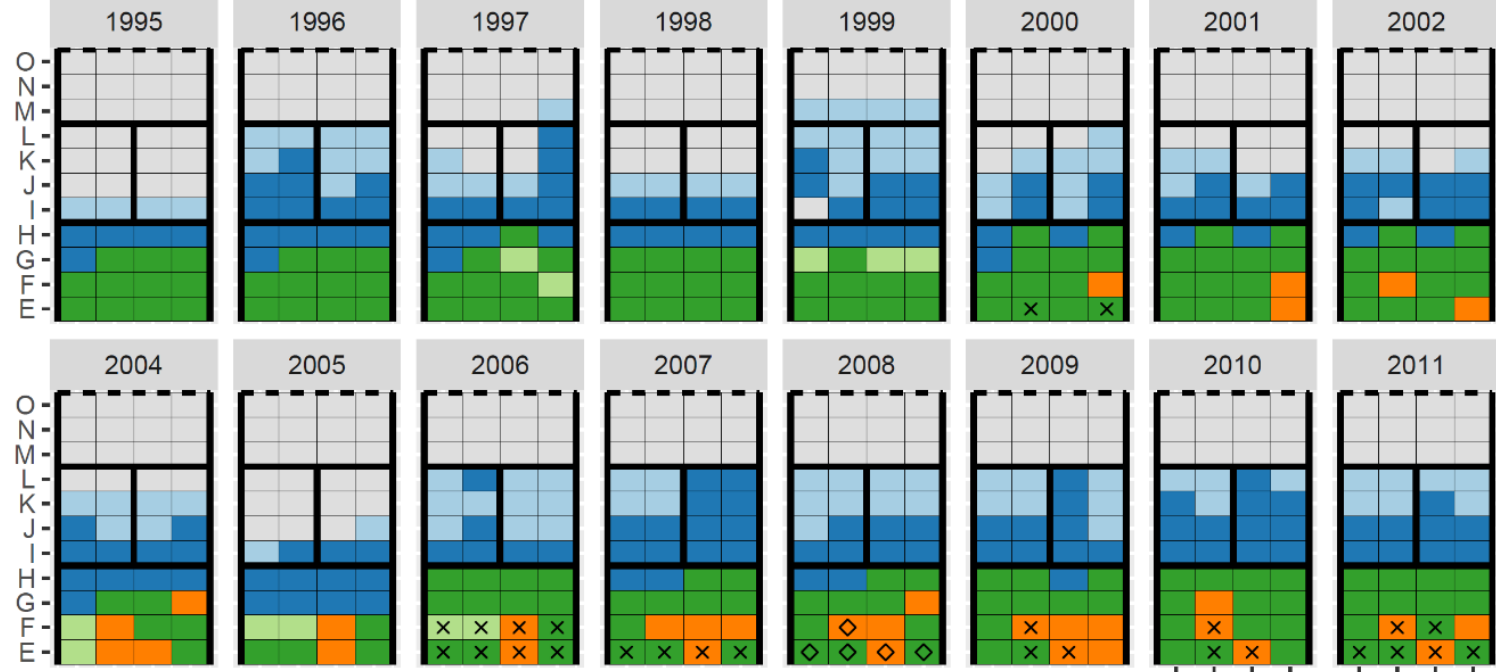

2003
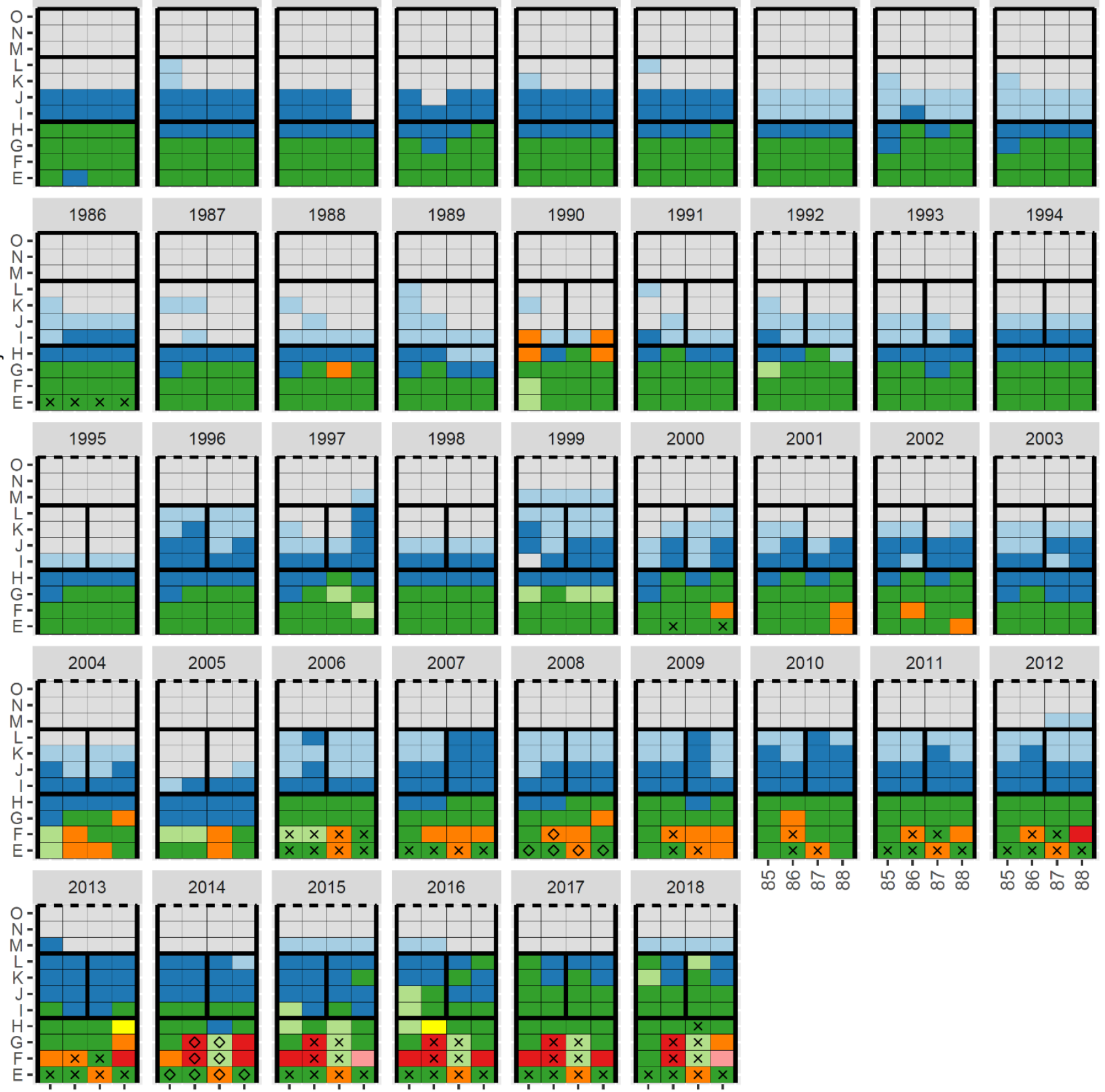

$2015 \quad 2016$

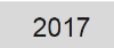

2018

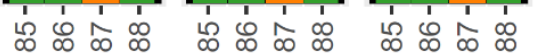
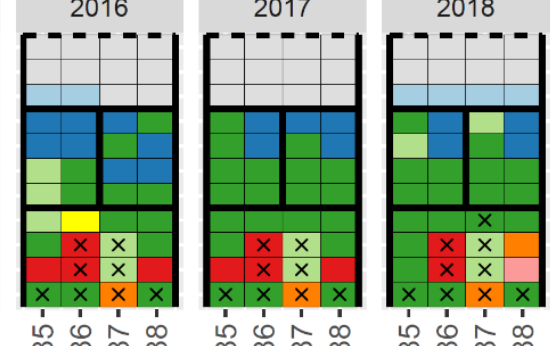

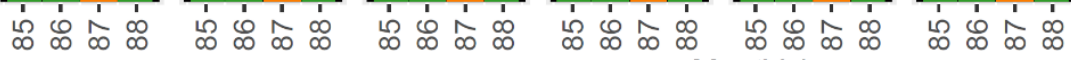
MeetVaknummer

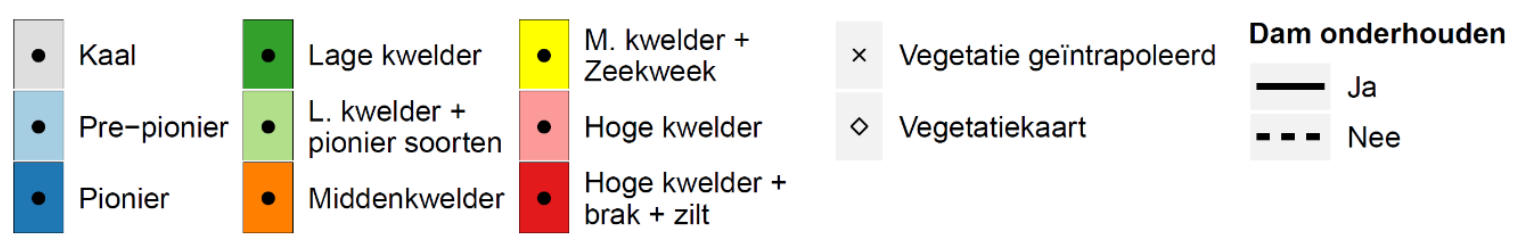


Friesland Midden: 101 - 104 (Blije \& Ferwerd Buitendijks)
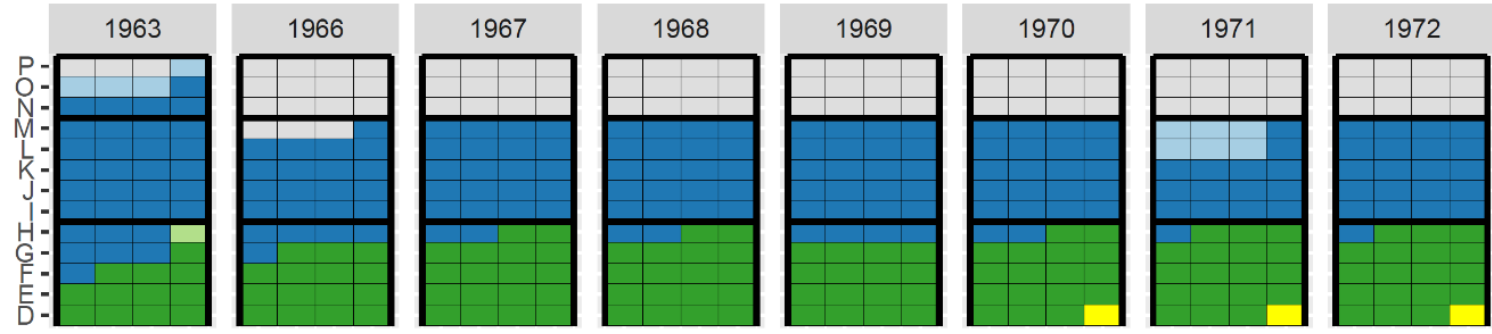

1973

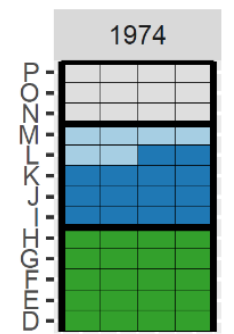

1975

1976

1977

1978

1979
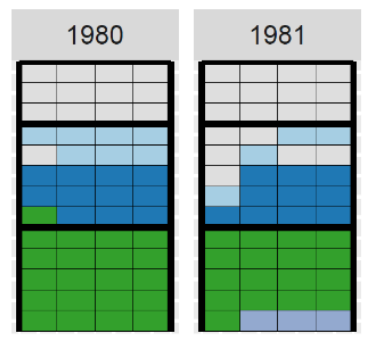

1984
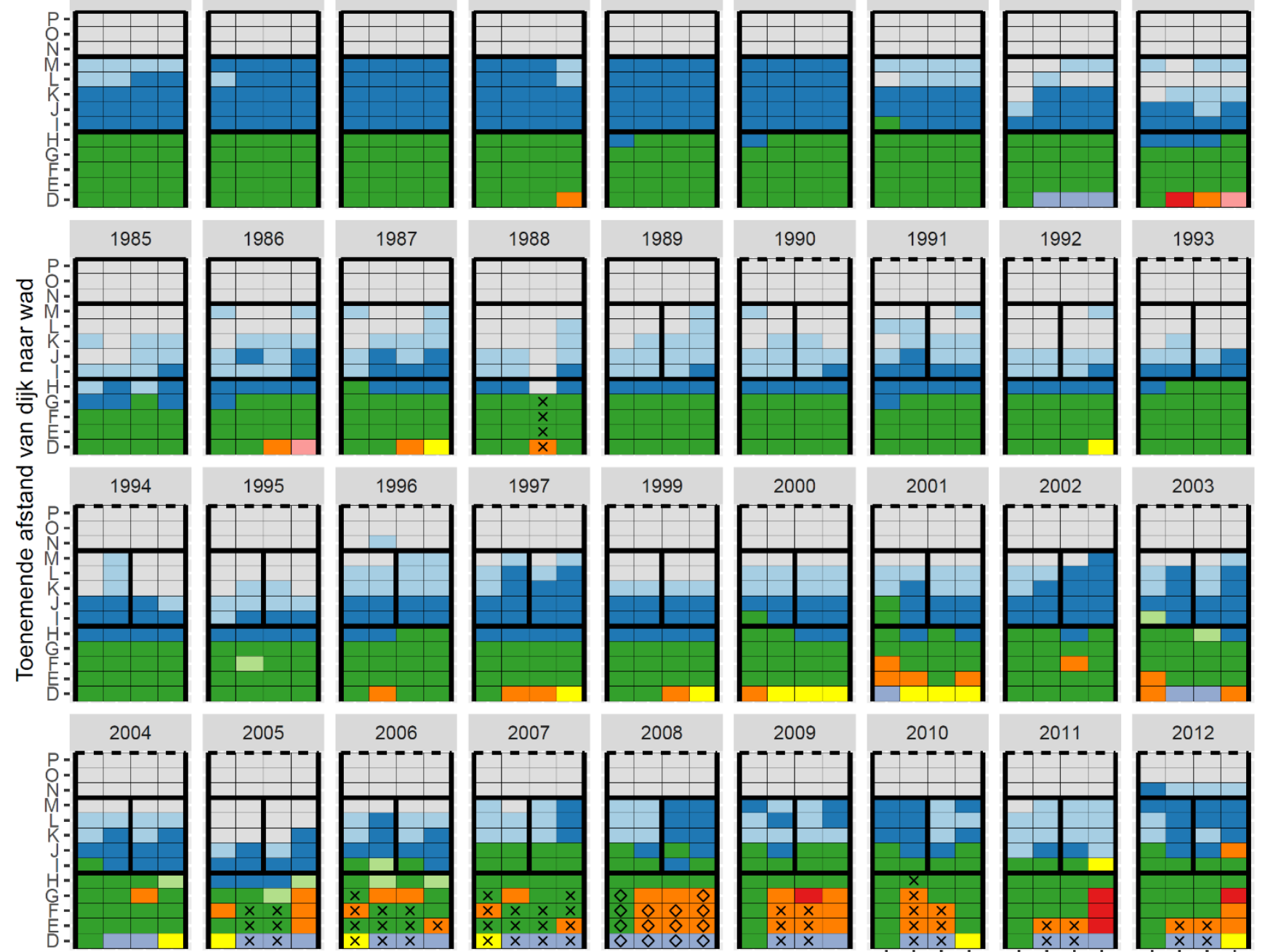

2011

2012

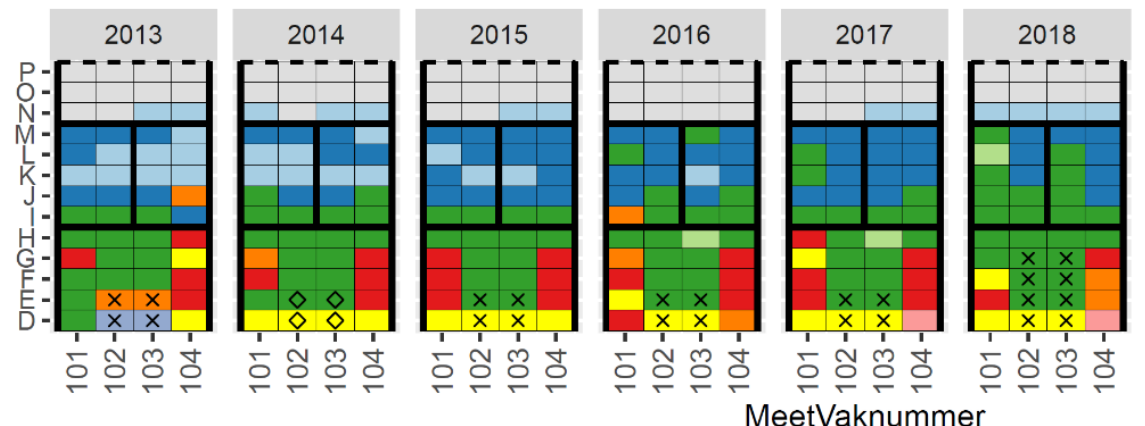

MeetVaknummer

\begin{tabular}{|c|c|c|c|c|c|c|c|c|}
\hline$\bullet$ & Kaal & $\bullet$ & Lage kwelder & $\bullet$ & $\begin{array}{l}\text { M. kwelder + } \\
\text { Zeekweek }\end{array}$ & - & $\begin{array}{l}\text { Hoge kwelder + } \\
\text { brak + zilt }\end{array}$ & Dam onderhouden \\
\hline$\bullet$ & Pre-pionier & $\bullet$ & $\begin{array}{l}\text { L. kwelder }+ \\
\text { pionier soorten }\end{array}$ & $\bullet$ & $\begin{array}{l}\text { M. kwelder }+ \\
\text { h. kwelder soorten }\end{array}$ & $x$ & Vegetatie geïntrapoleerd & - - Nee \\
\hline$\bullet$ & Pionier & $\bullet$ & Middenkwelder & $\bullet$ & Hoge kwelder & $\diamond$ & Vegetatiekaart & \\
\hline
\end{tabular}


Friesland Midden: 121 - 124 (Blije \& Ferwerd Buitendijks)
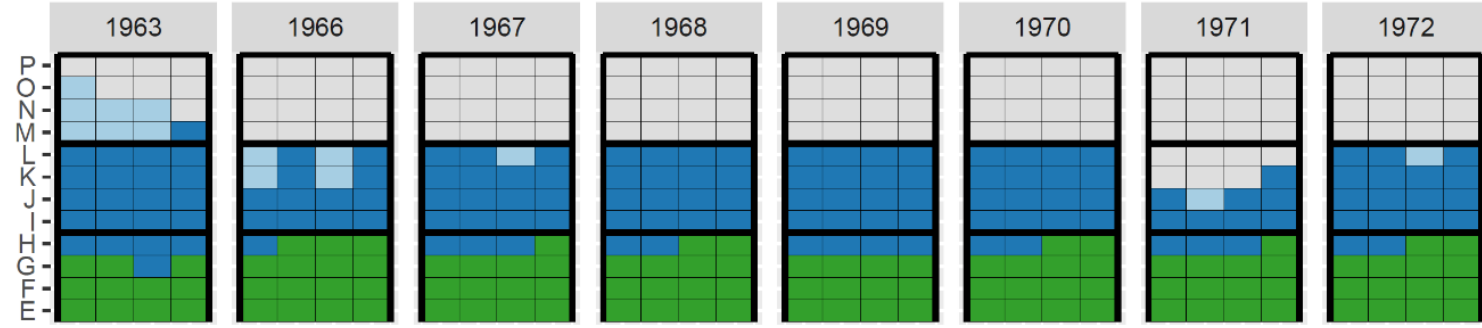

1973
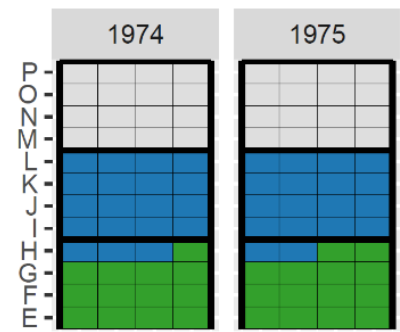

1976

1977

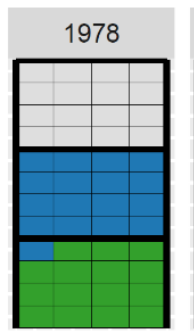

1979

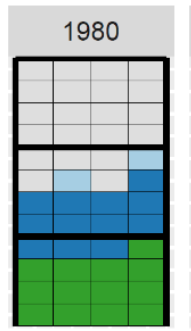

1981
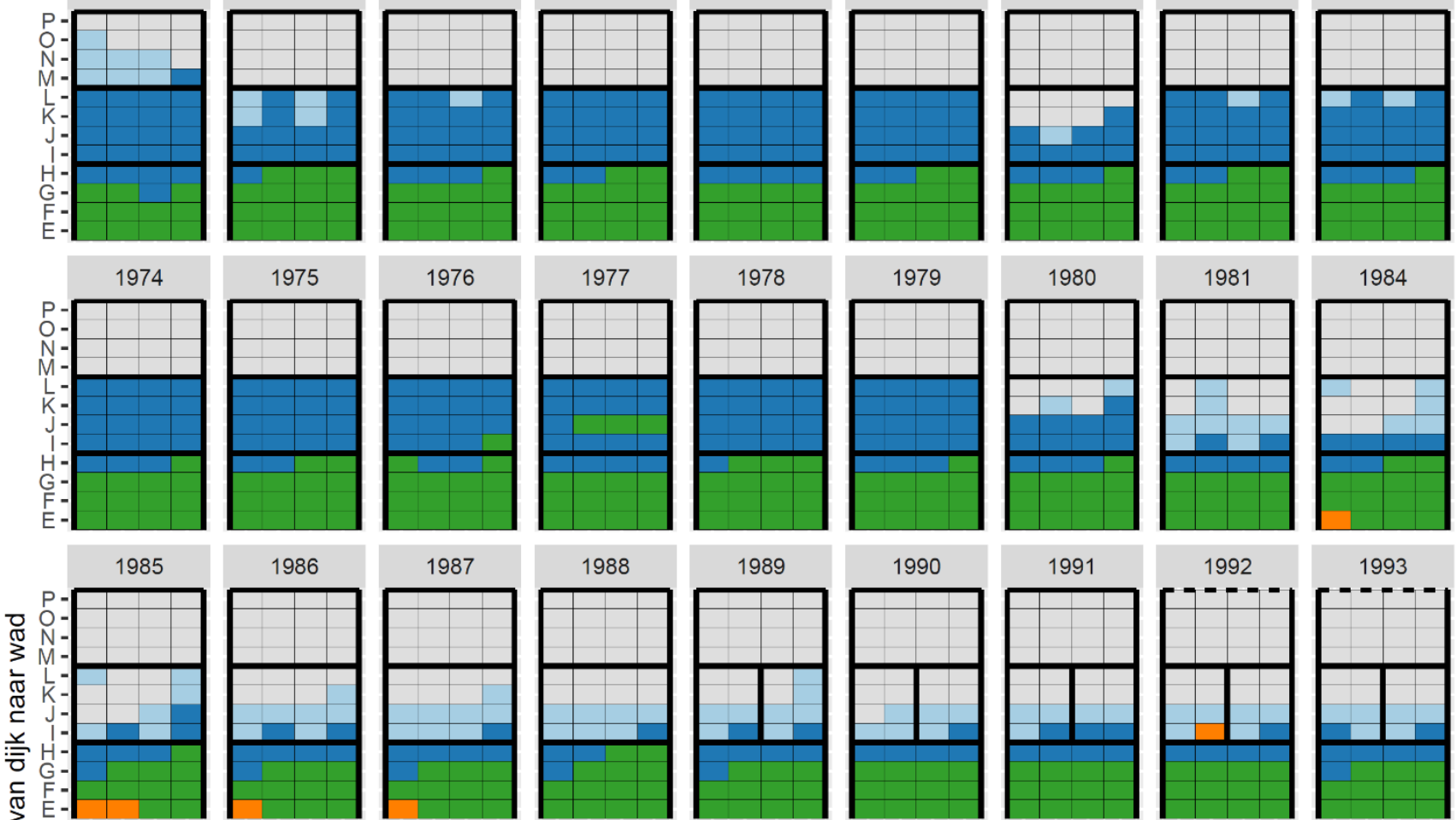

1987
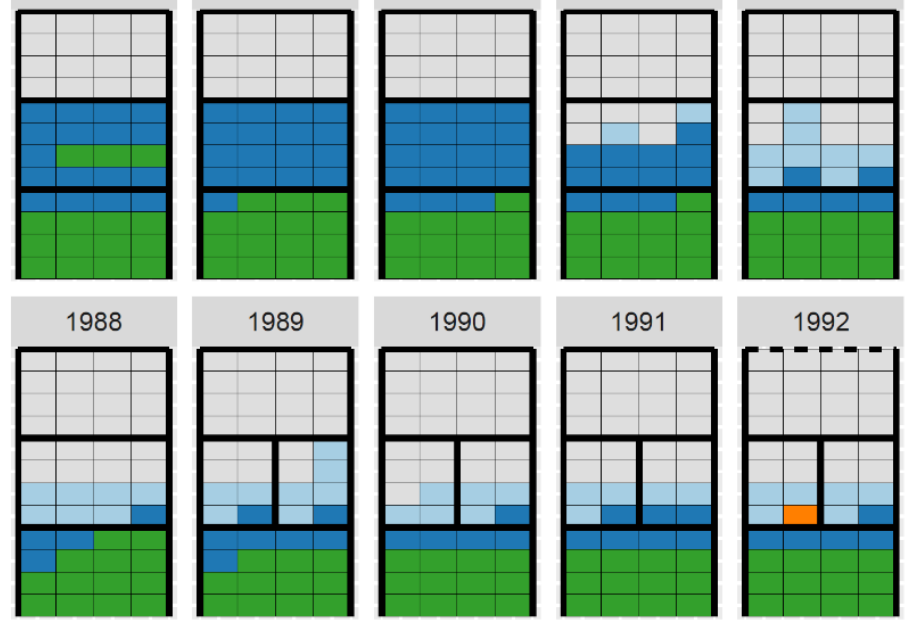

1984
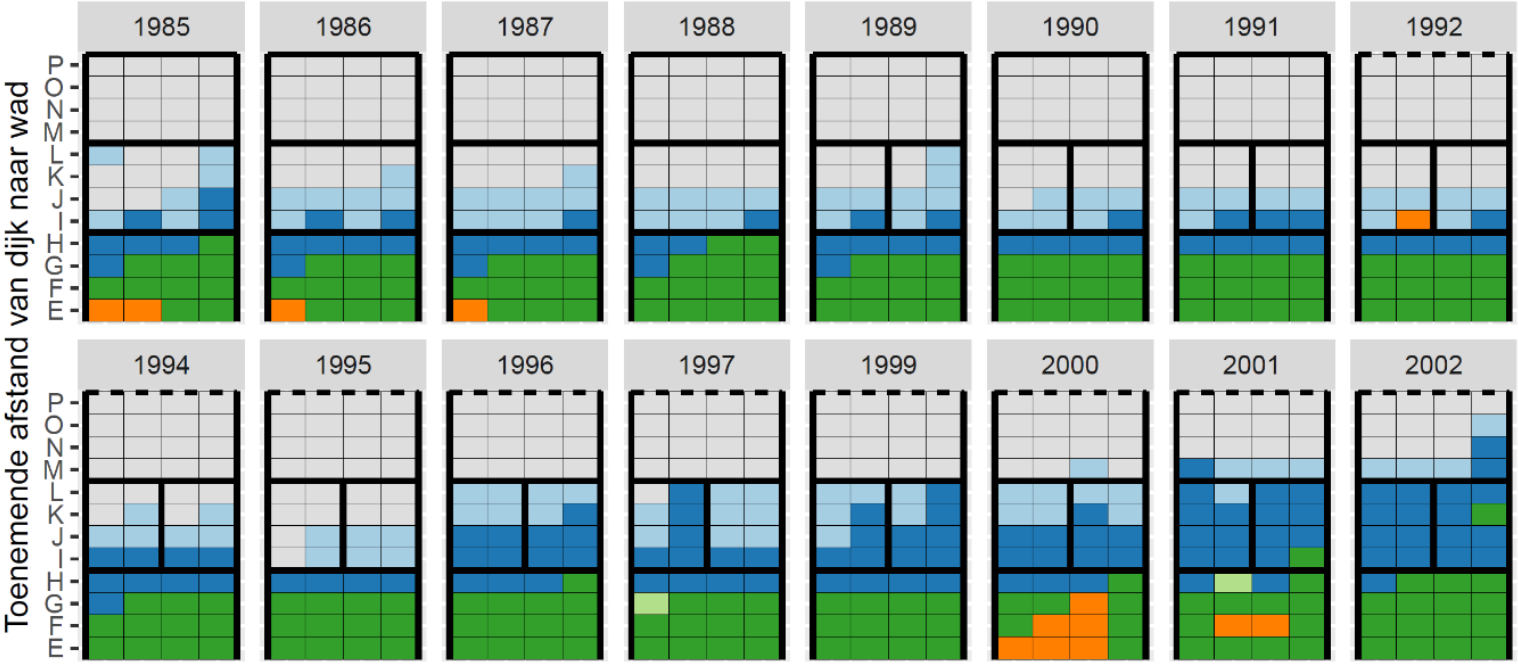

1993

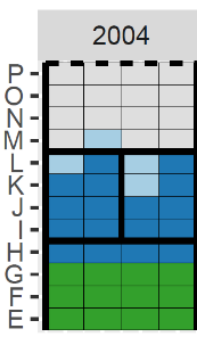

2005

2006

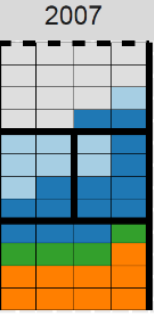

2008

2009

2010

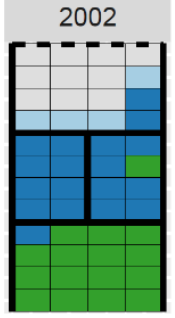

2003
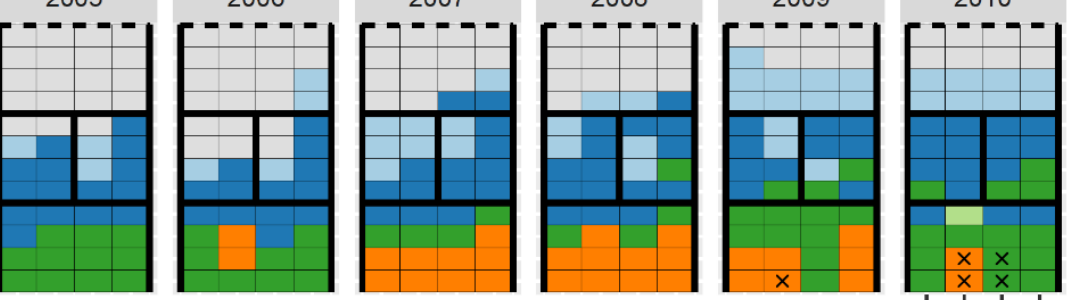

2011
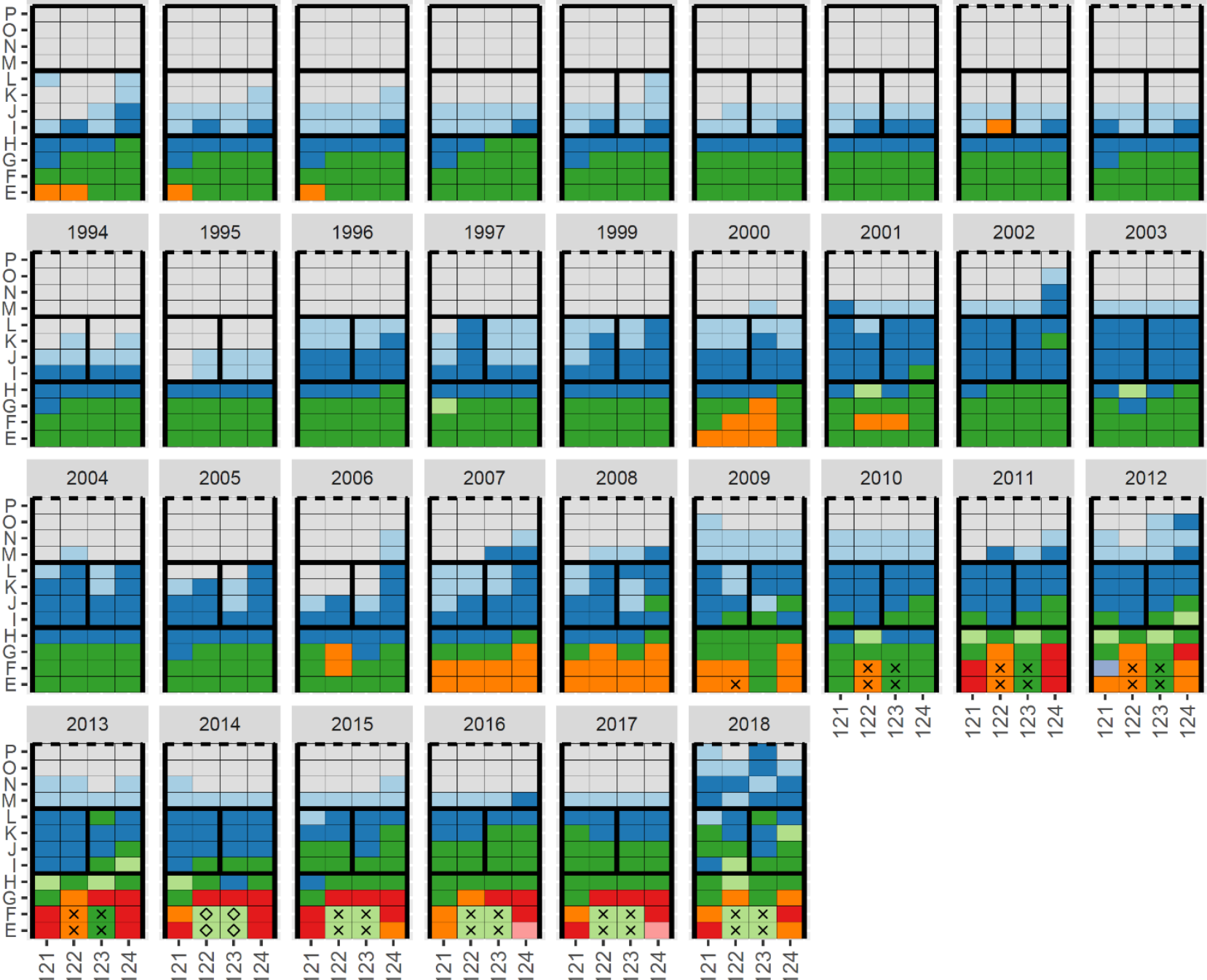

2015

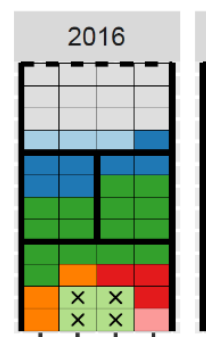

2017

2018

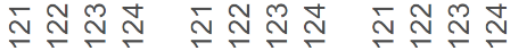
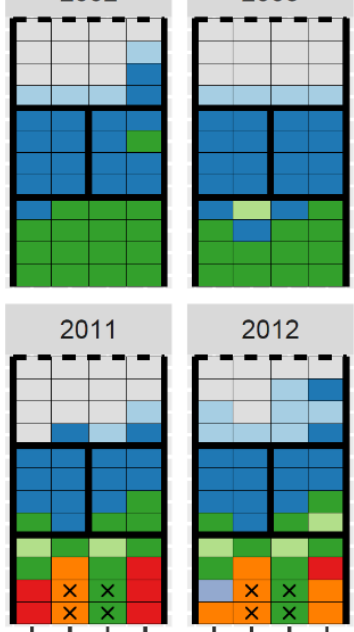

2012
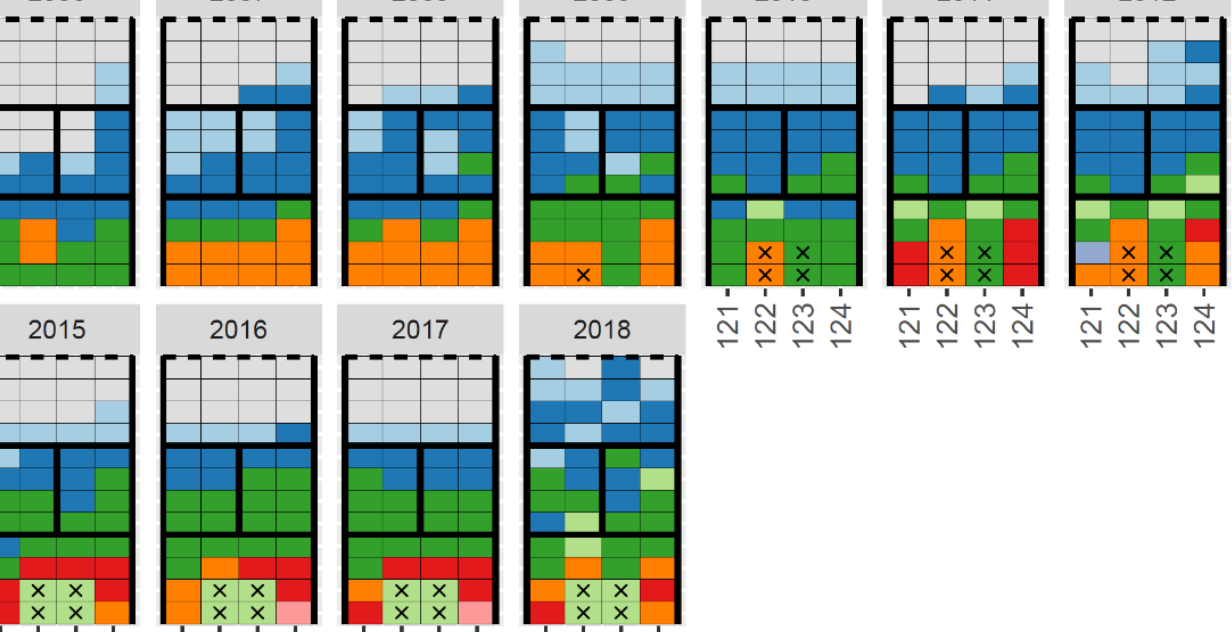

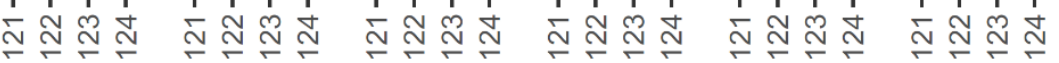

\section{MeetVaknummer}

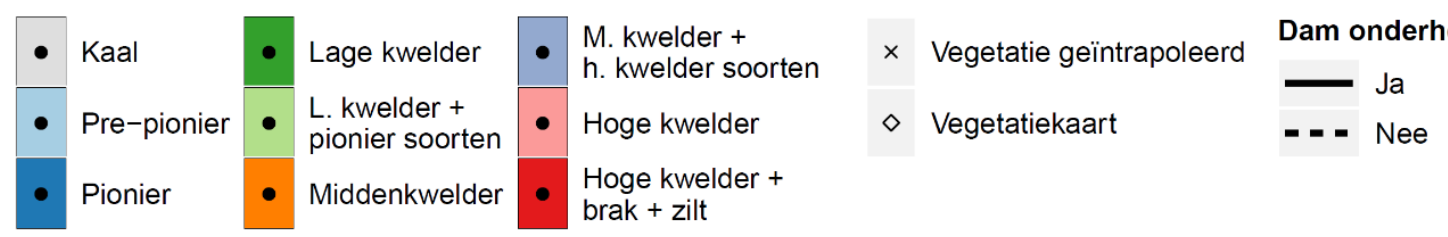


Friesland Midden: 145 - 148 (Blije \& Ferwerd Buitendijks)
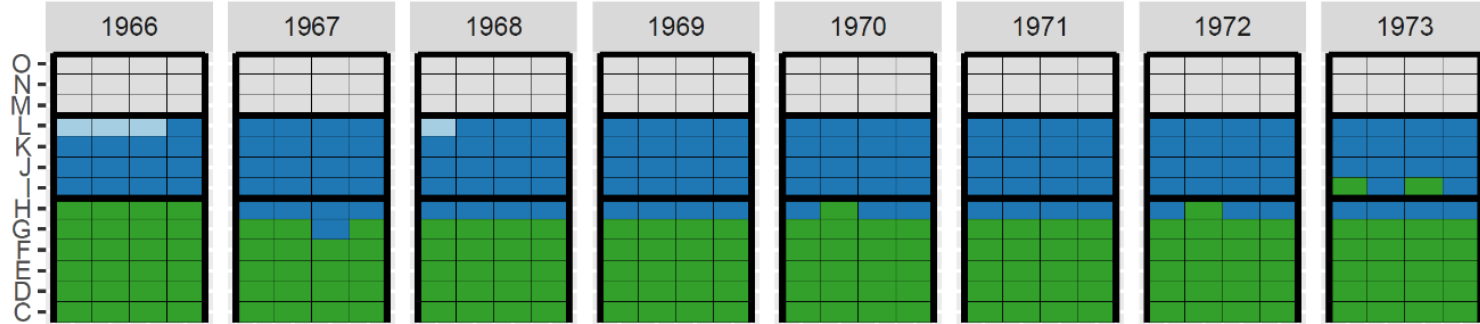

1974

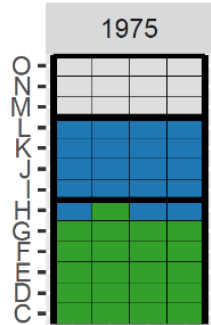

1976

1977

1978

1979

1980

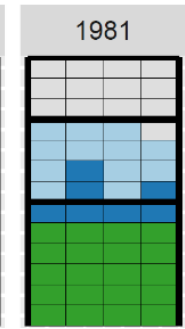

1984
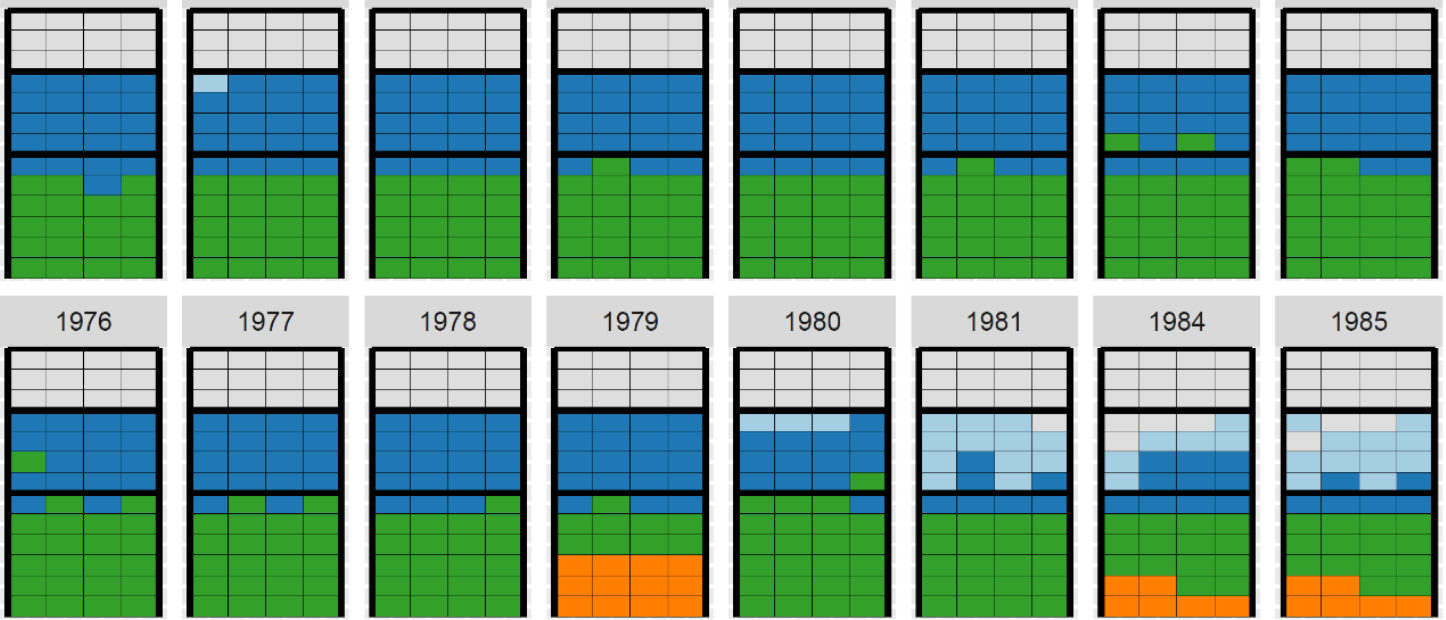

1985
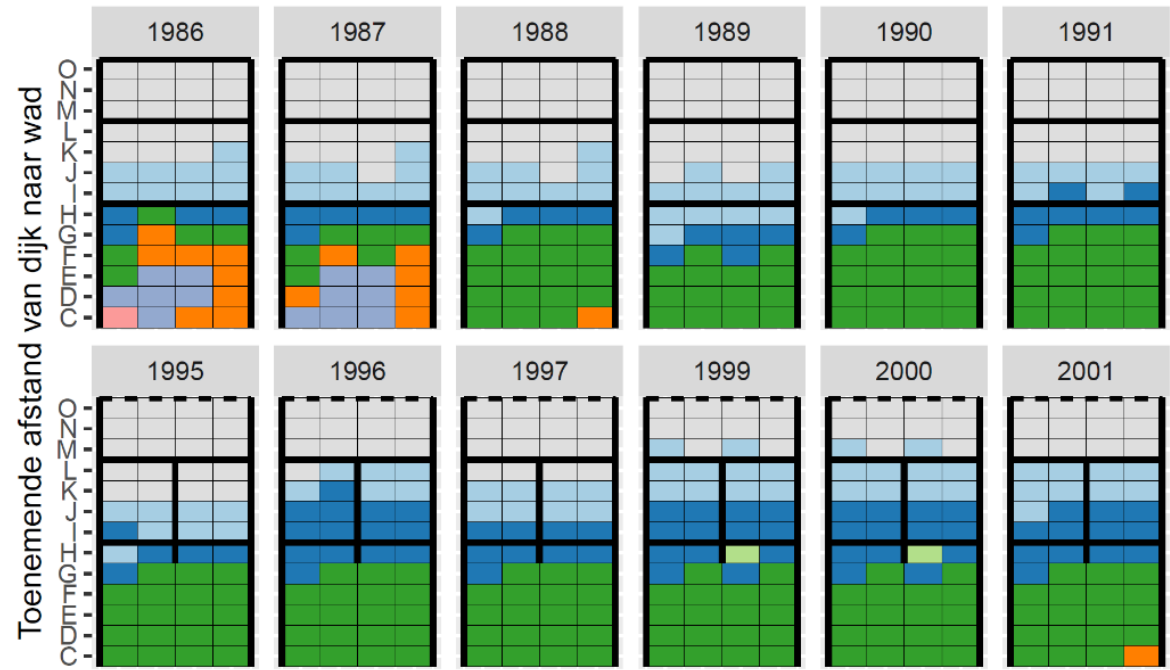

1992
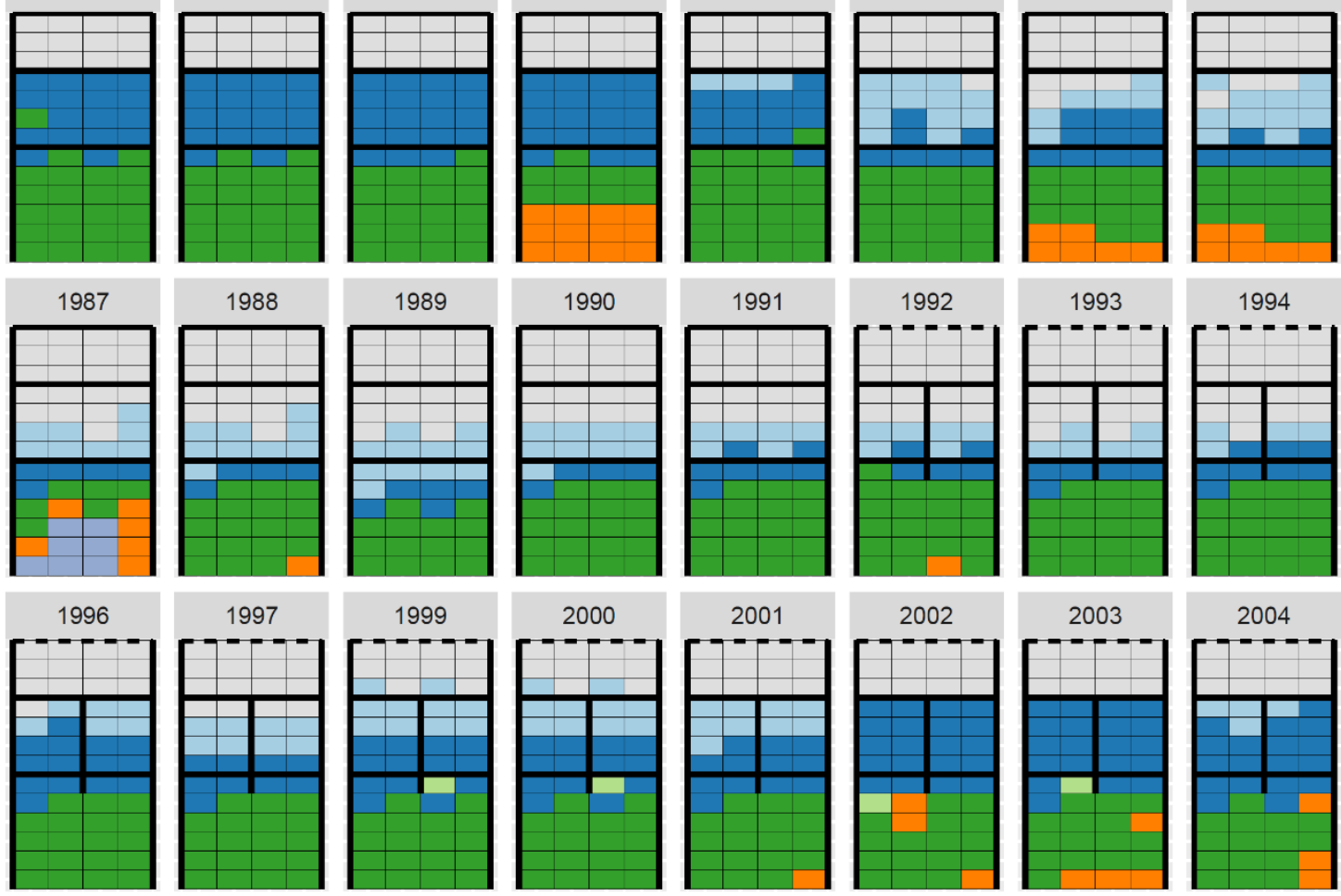

1994
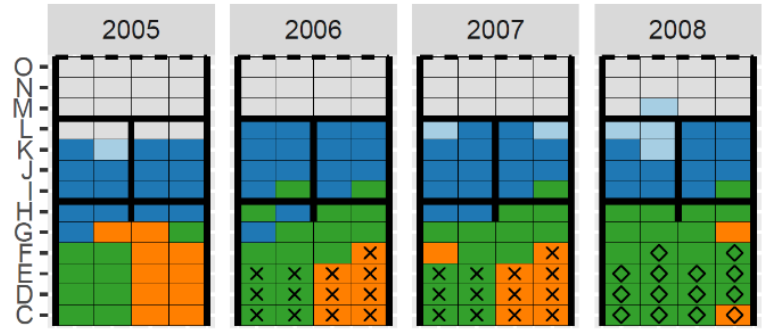

2009
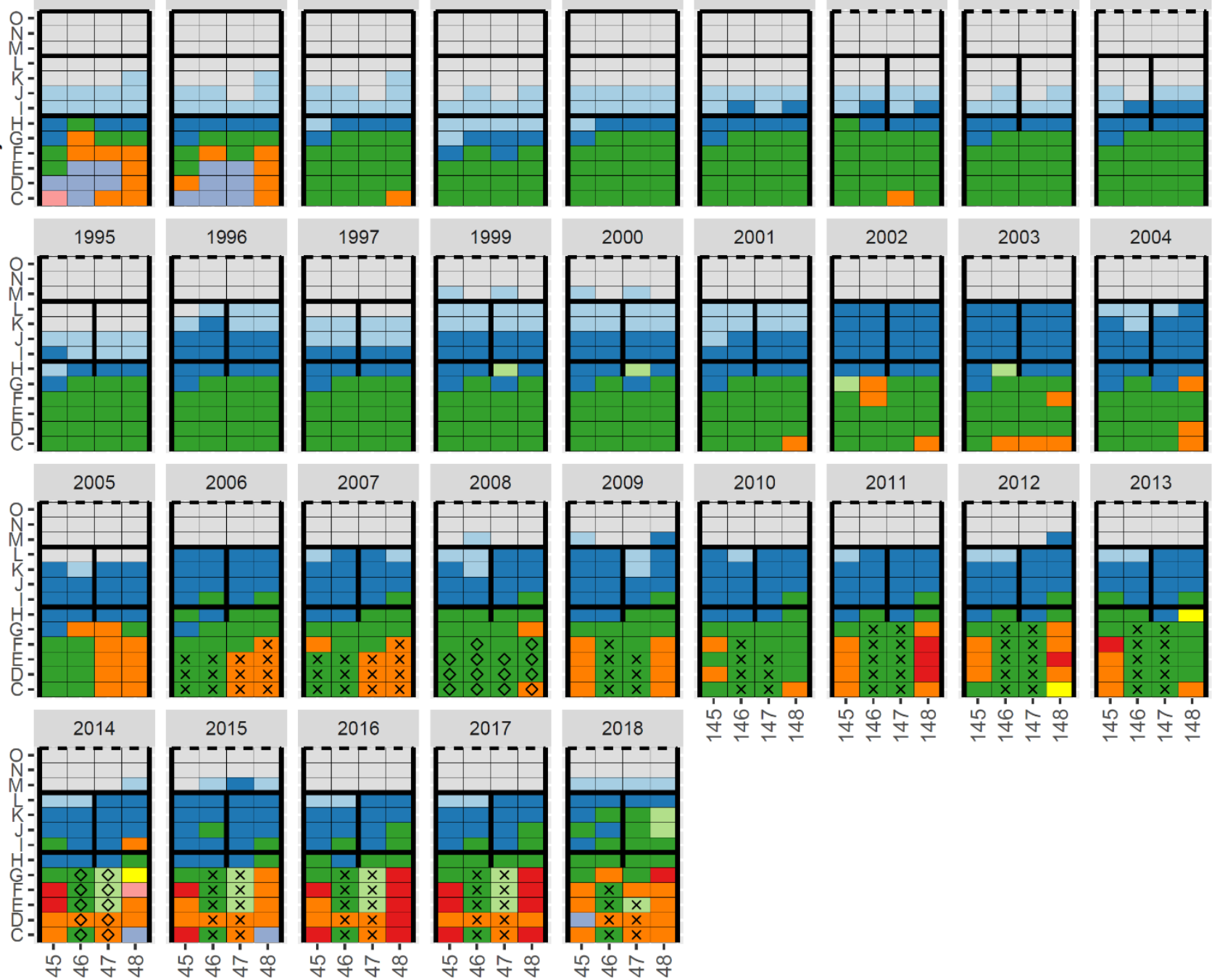

2004
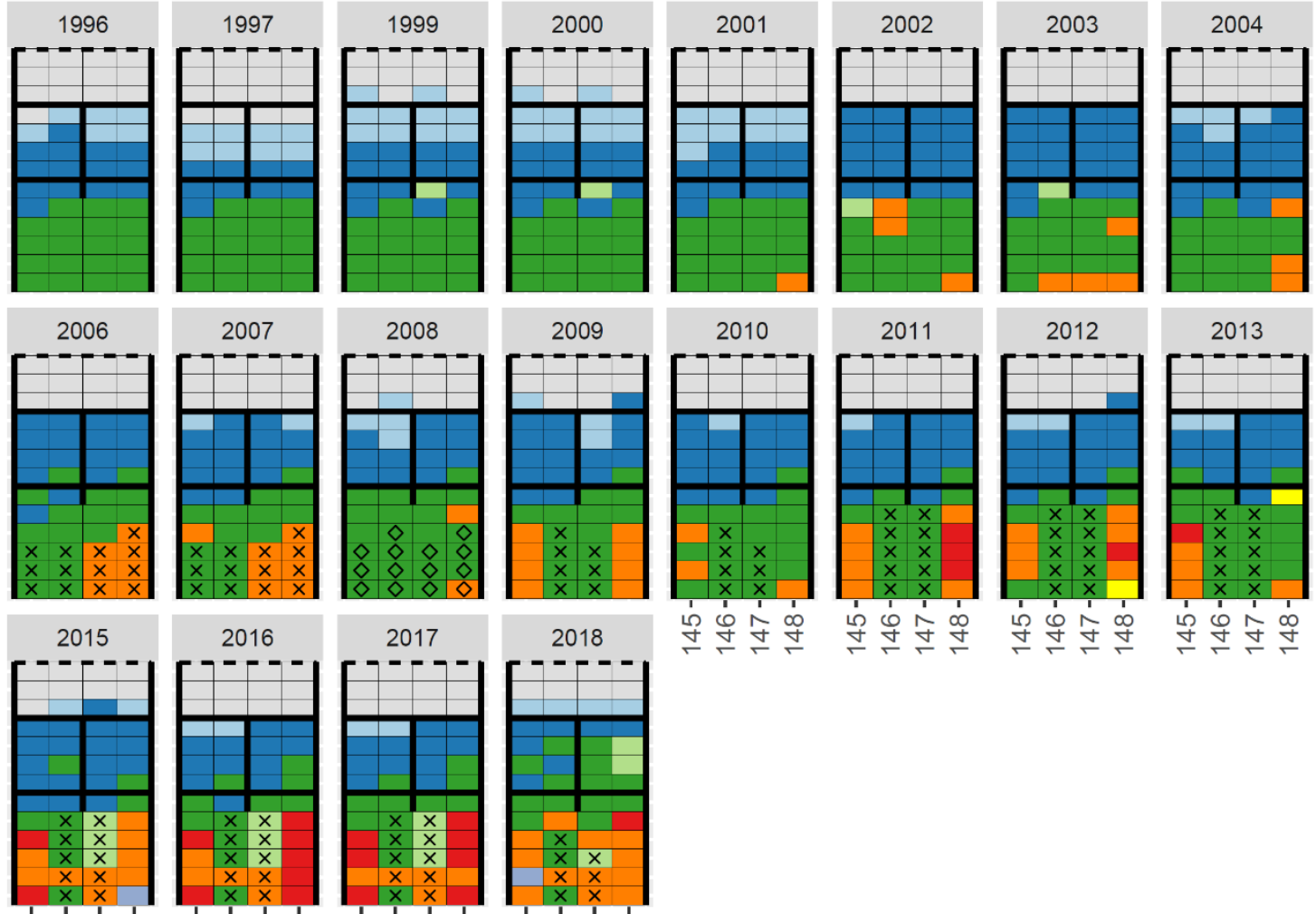

2018

守亭守站

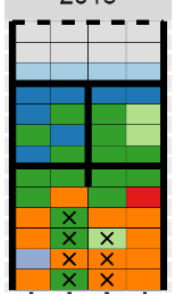

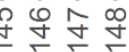

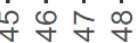

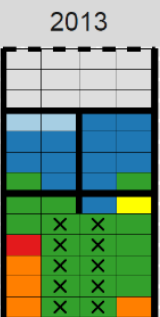

$$
\text { 守亭守票 }
$$

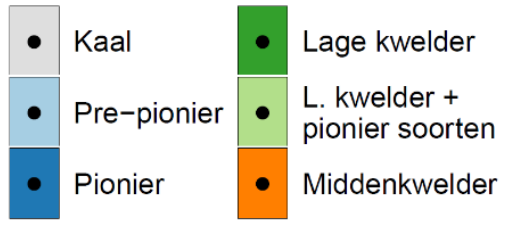

- M. kwelder + Zeekweek

- Hoge kwelder +

brak + zilt

- M. kwelder +

h. kwelder soorten $\times$ Vegetatie geïntrapoleerd

- Hoge kwelder

$\diamond$ Vegetatiekaart
Dam onderhouden

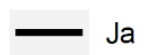

- - - Nee 
Friesland Midden: 167 - 170 (Holwerd Buitendijks West)
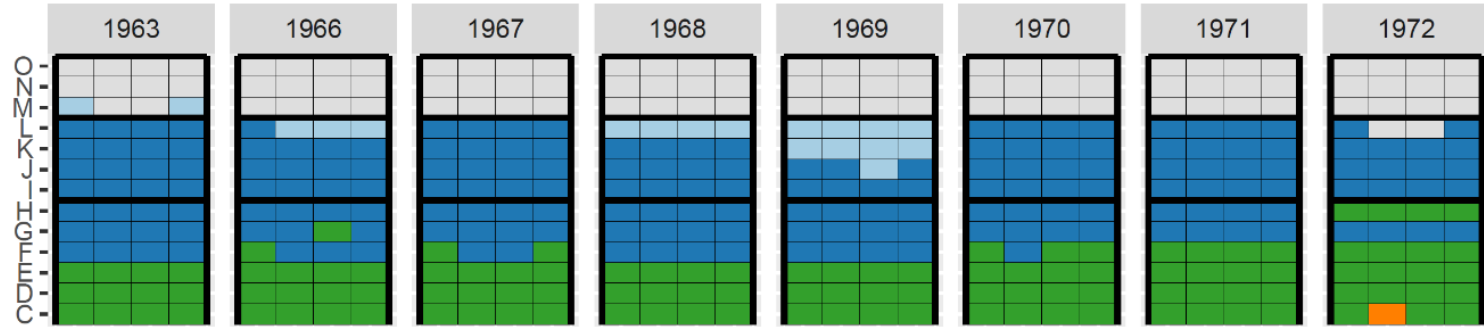

1973

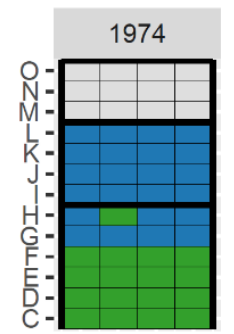

1975

1976

1977

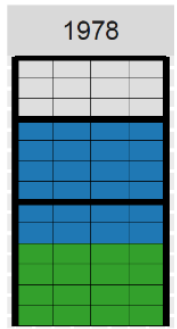

1979

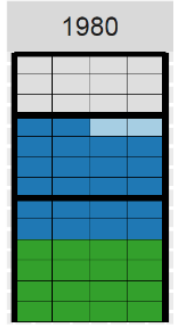

1981
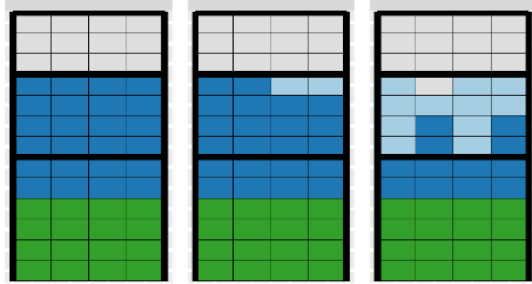

1984
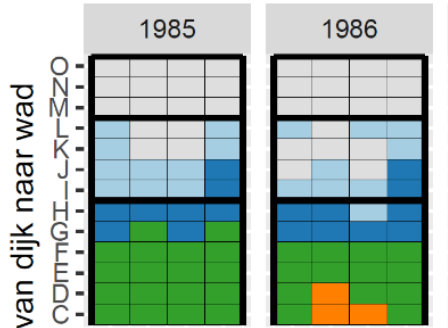

1987
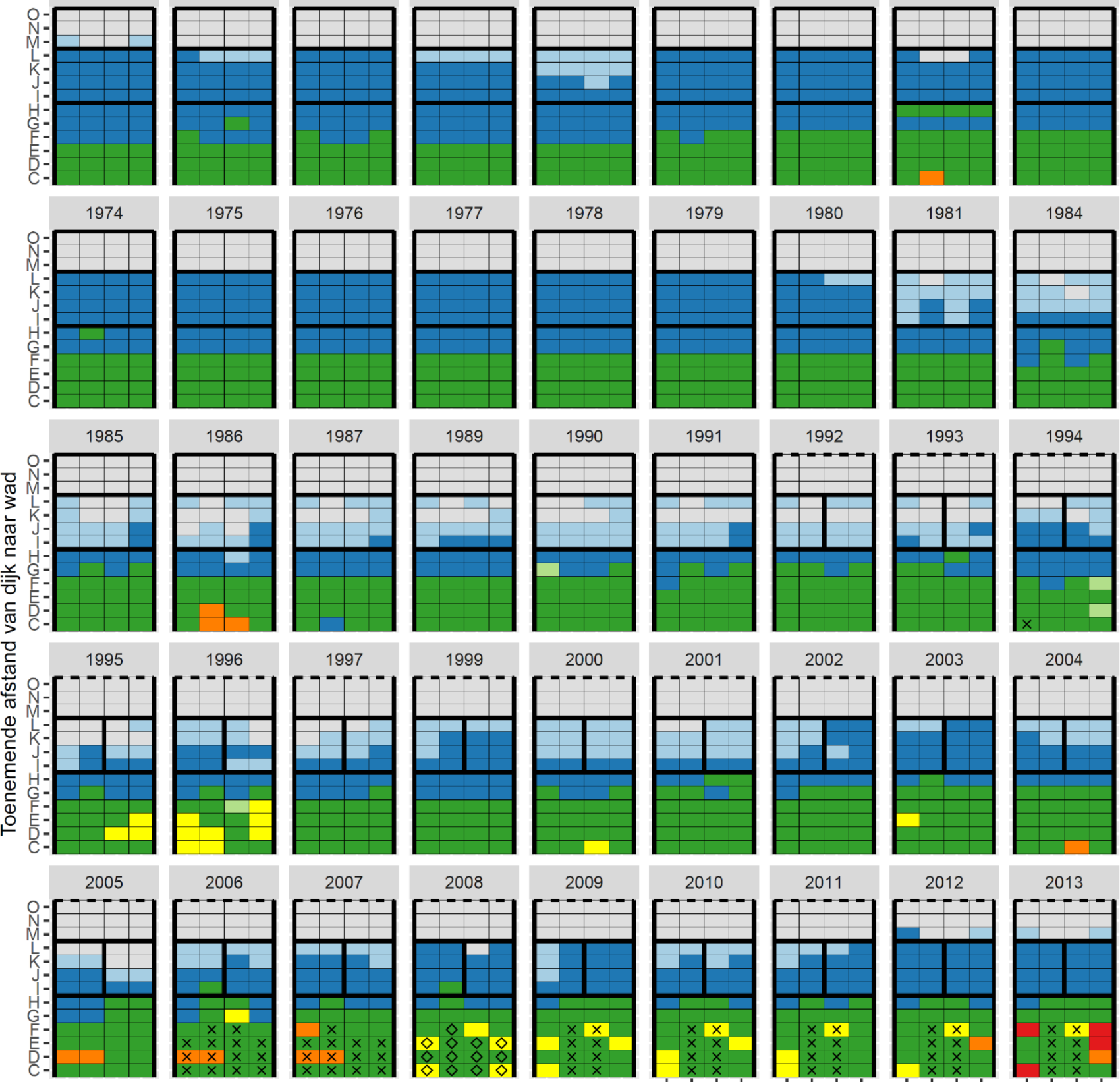

2013
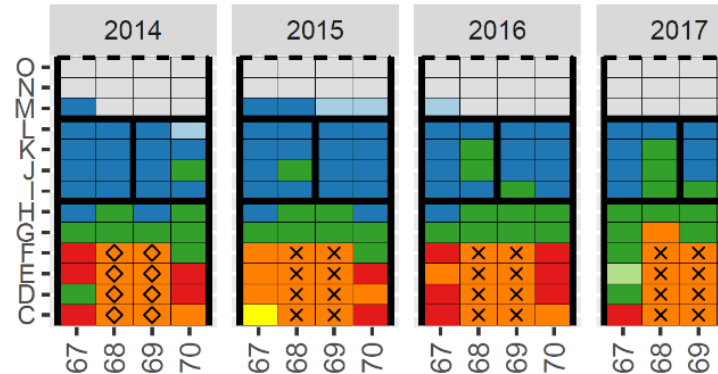

2018

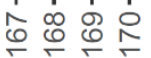

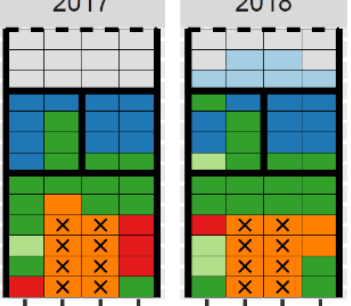

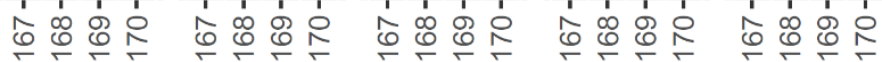

MeetVaknummer

\begin{tabular}{|c|c|c|c|c|c|c|c|c|}
\hline - & Kaal & • & Lage kwelder & $\bullet$ & $\begin{array}{l}\text { M. kwelder + } \\
\text { Zeekweek }\end{array}$ & $x$ & Vegetatie geïntrapoleerd & $\begin{array}{l}\text { Dam onderl } \\
\text { Ja }\end{array}$ \\
\hline - & Pre-pionier & $\bullet$ & $\begin{array}{l}\text { L. kwelder + } \\
\text { pionier soorten }\end{array}$ & $\bullet$ & $\begin{array}{l}\text { Hoge kwelder + } \\
\text { brak + zilt }\end{array}$ & $\diamond$ & Vegetatiekaart & -.-Nee \\
\hline & Pionier & 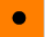 & Middenkwelder & & & & & \\
\hline
\end{tabular}


Friesland Midden: 183 - 186 (Holwerd Buitendijks West)
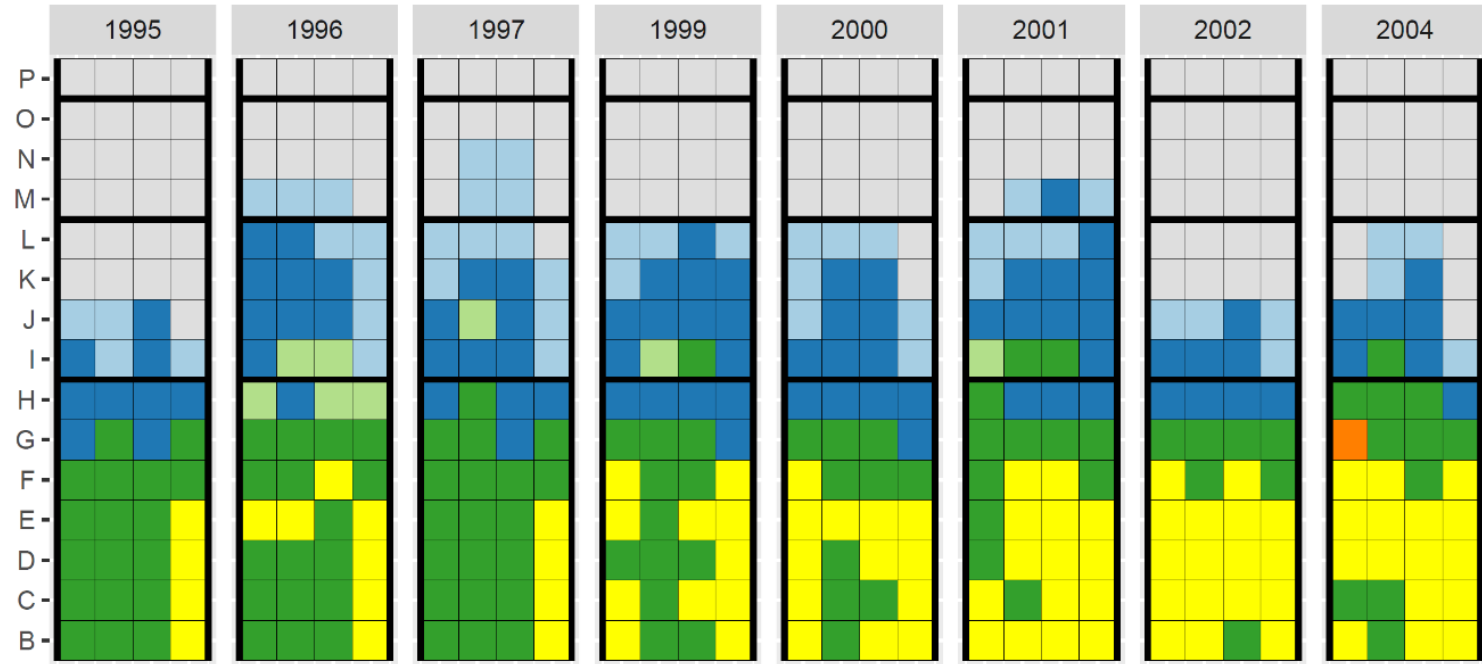

2005
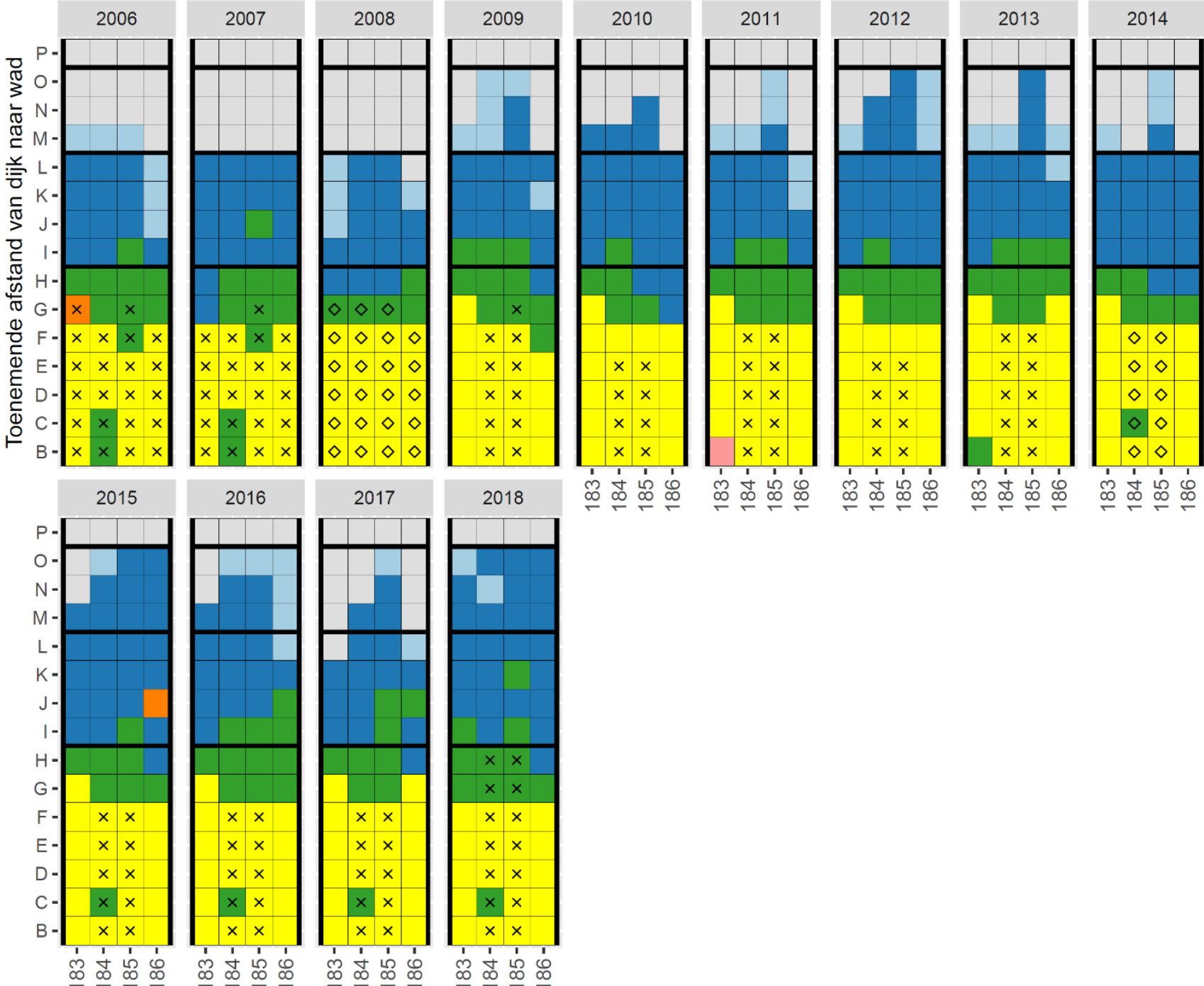

2017

2018

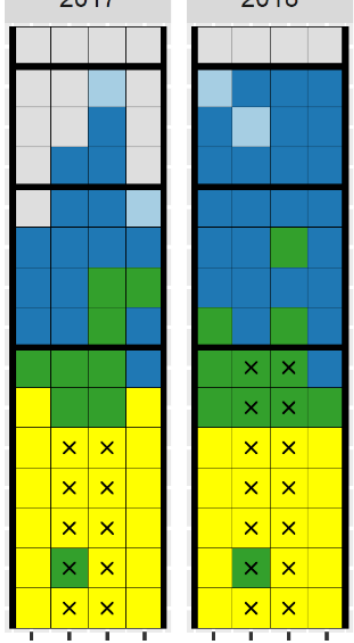

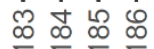

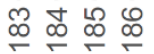

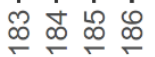

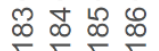

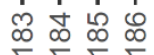

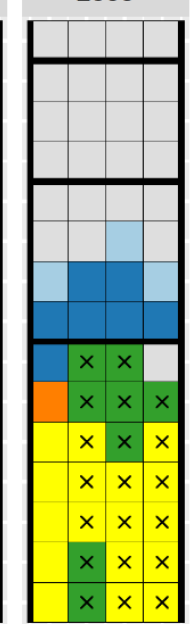

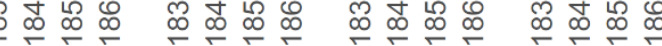

\section{MeetVaknummer}

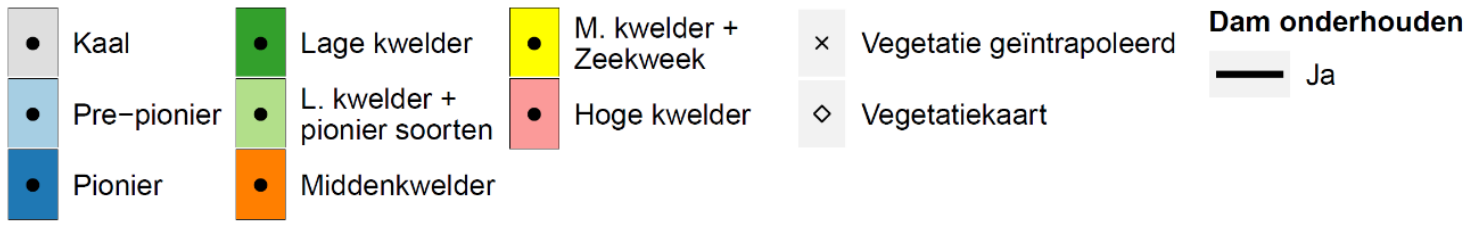


Friesland Oost: 205 - 208 (Holwerd Buitendijks Oost)
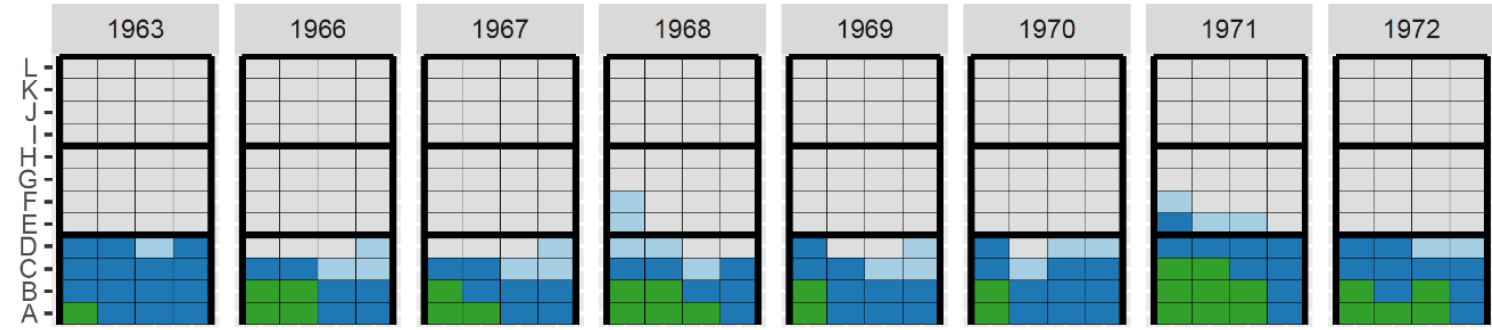

1973
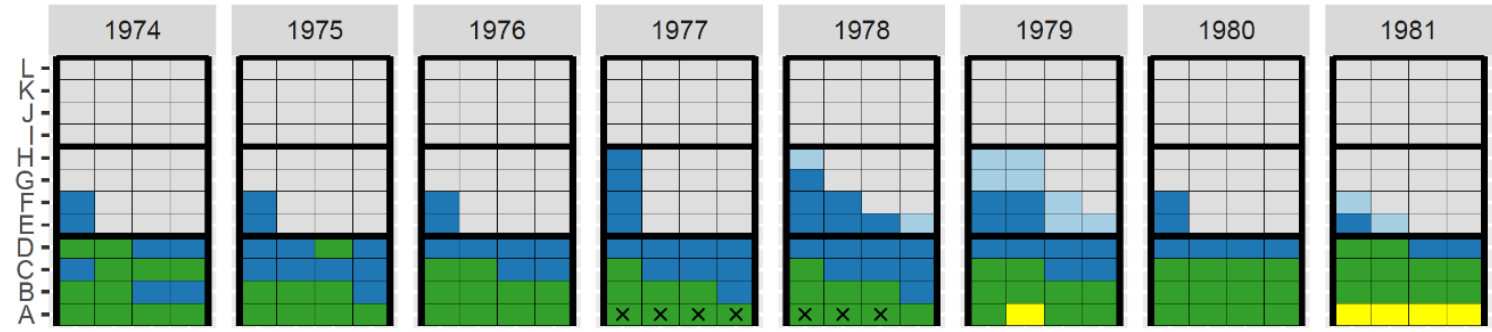

1984
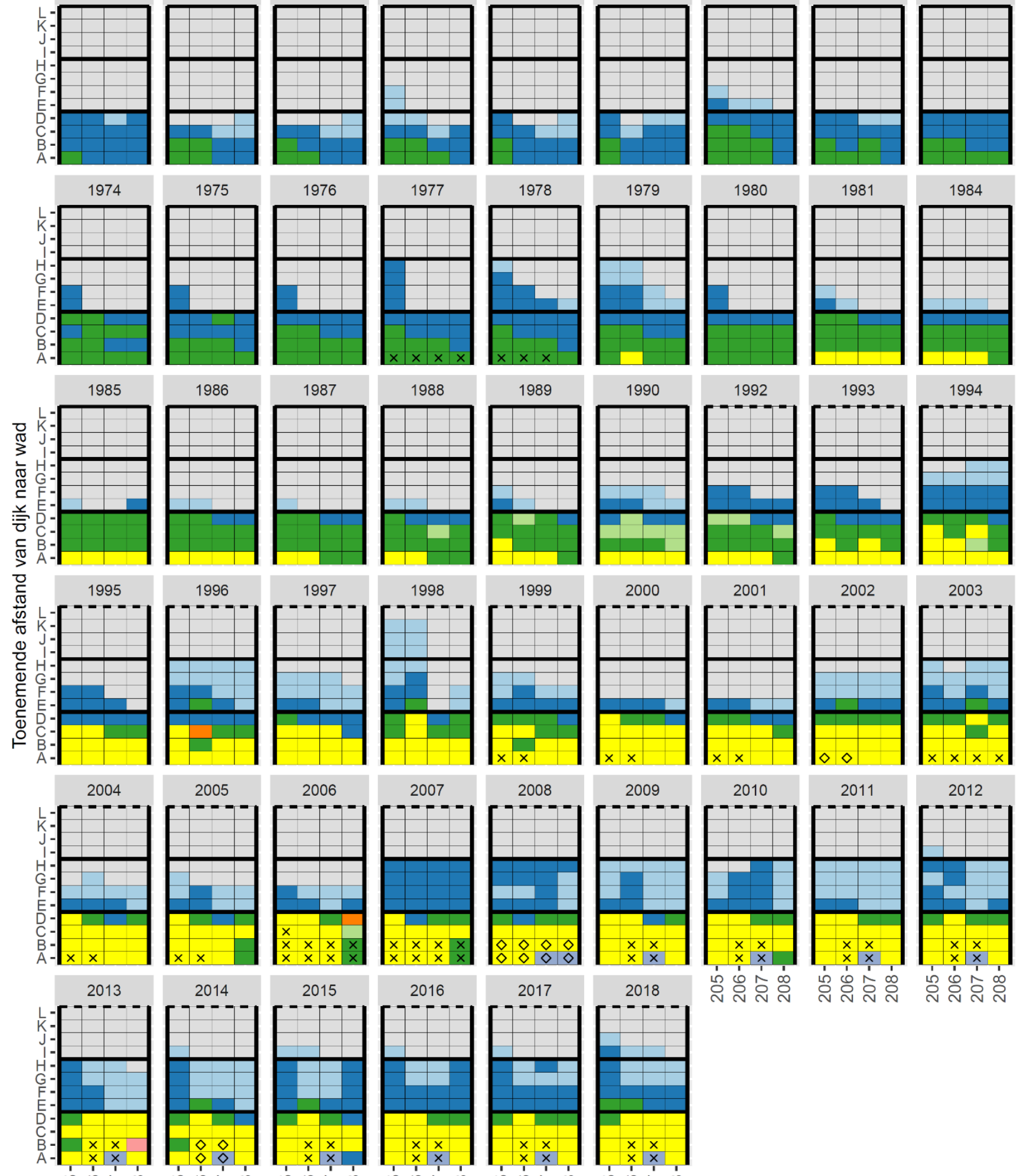

\section{8}
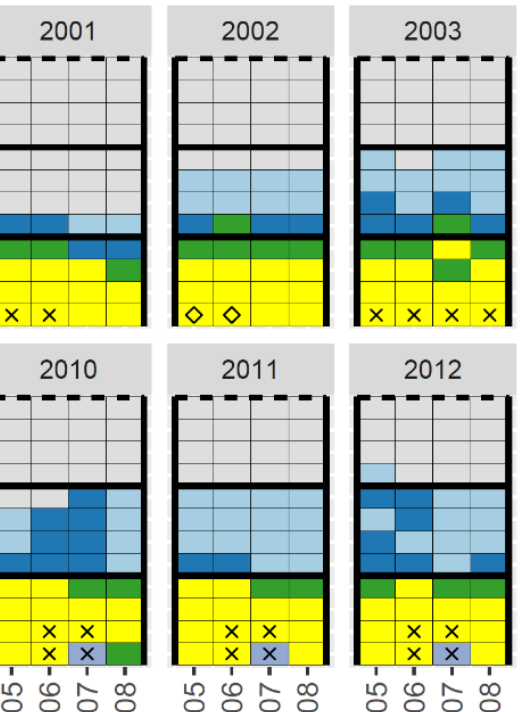

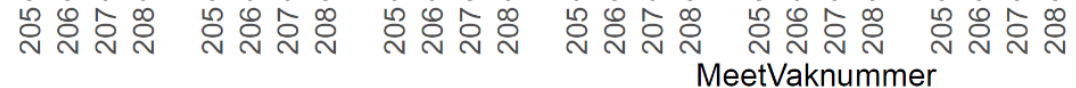

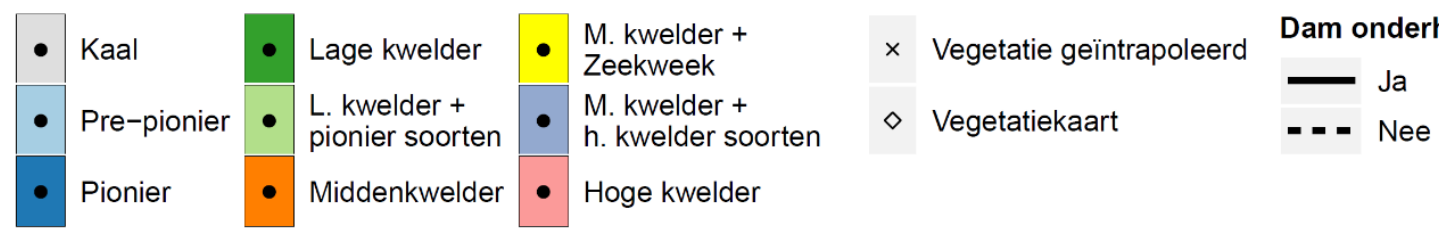


Groningen West: 260 - 263 (Westpolder)
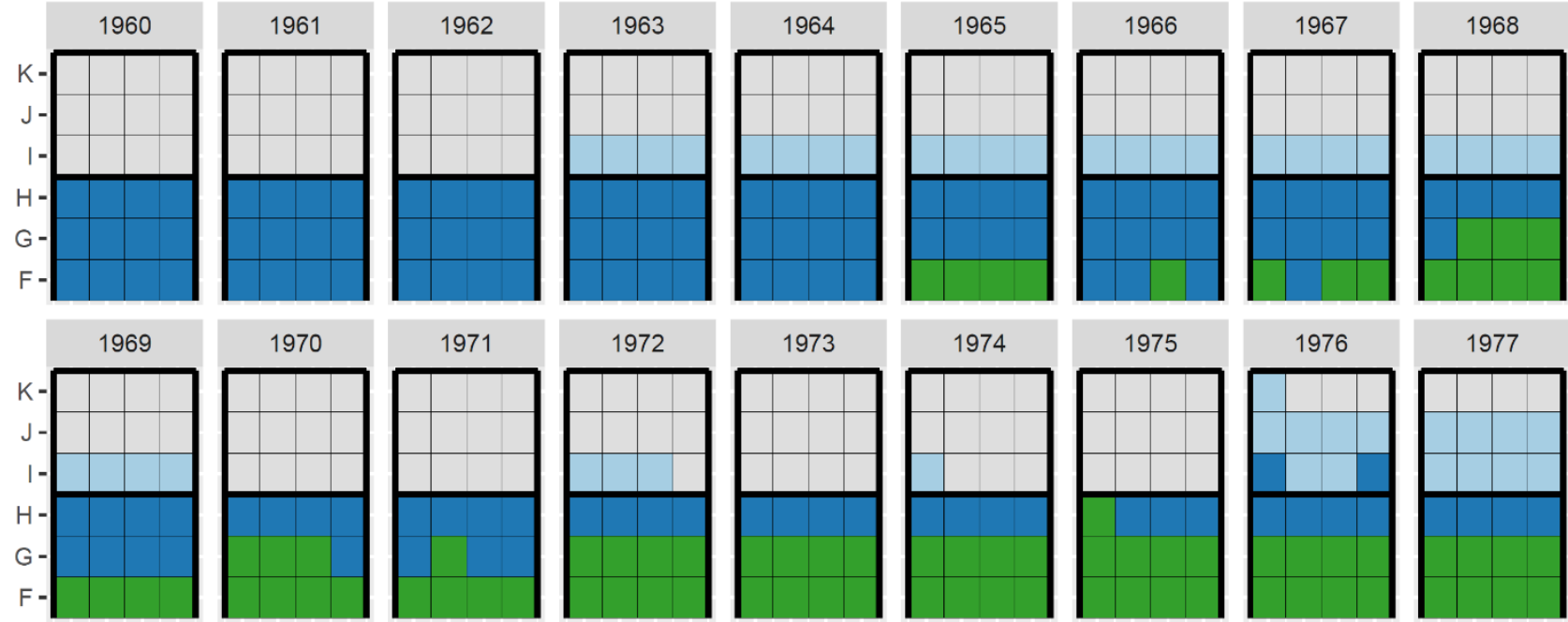

1977
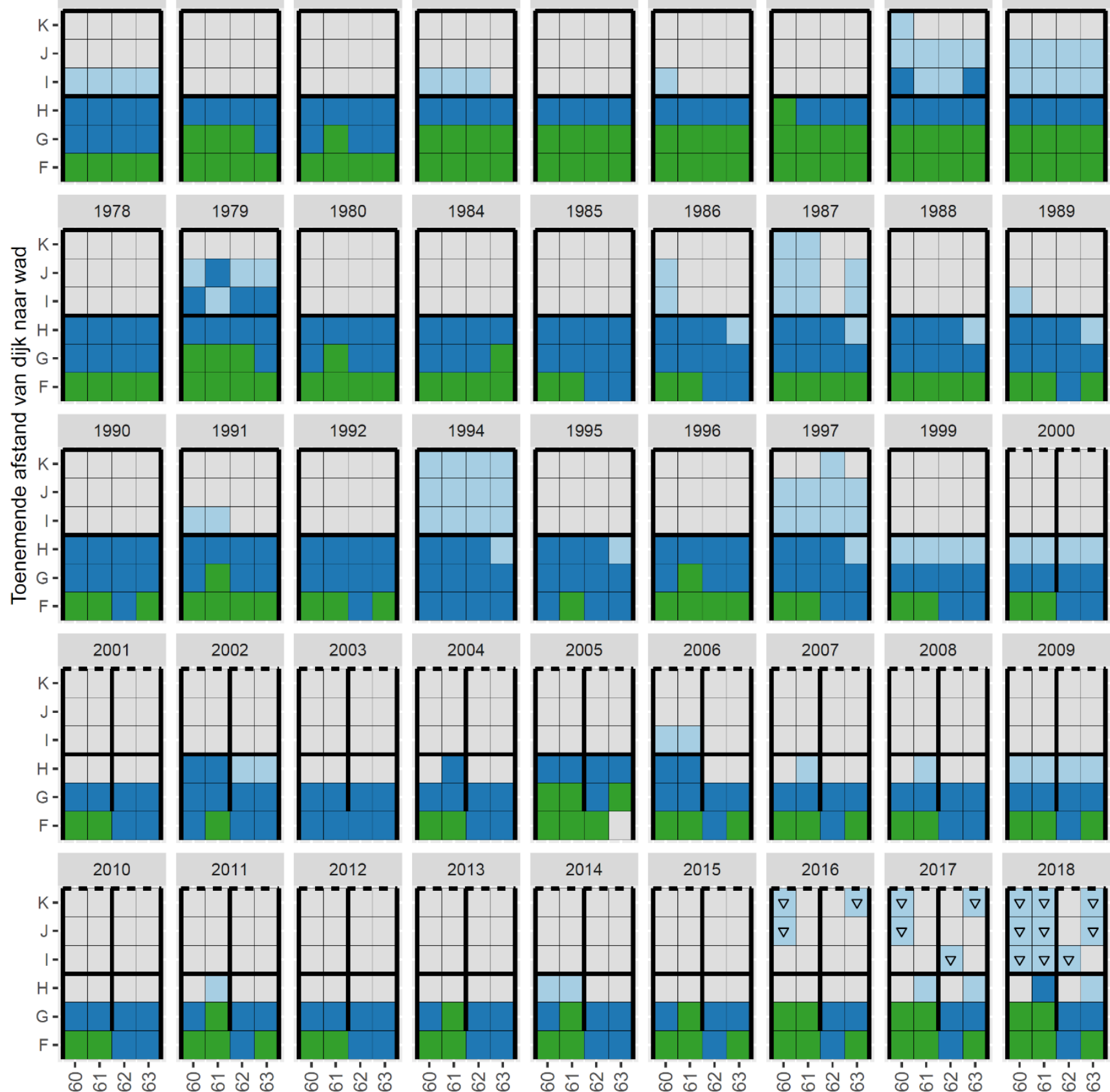

2009

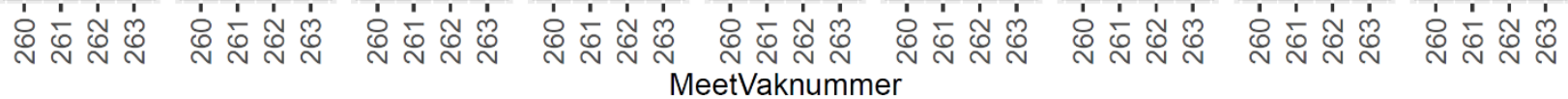

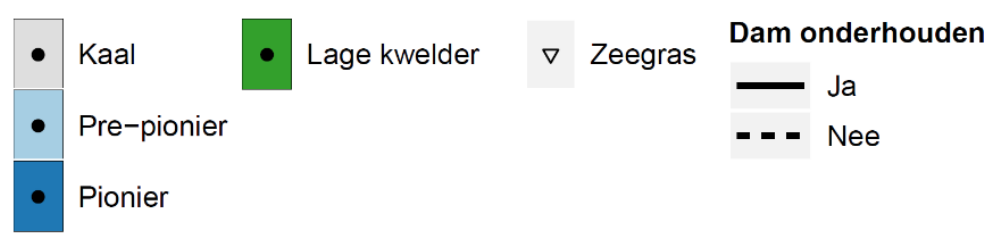


Groningen West: 286 - 289 (Julianapolder)
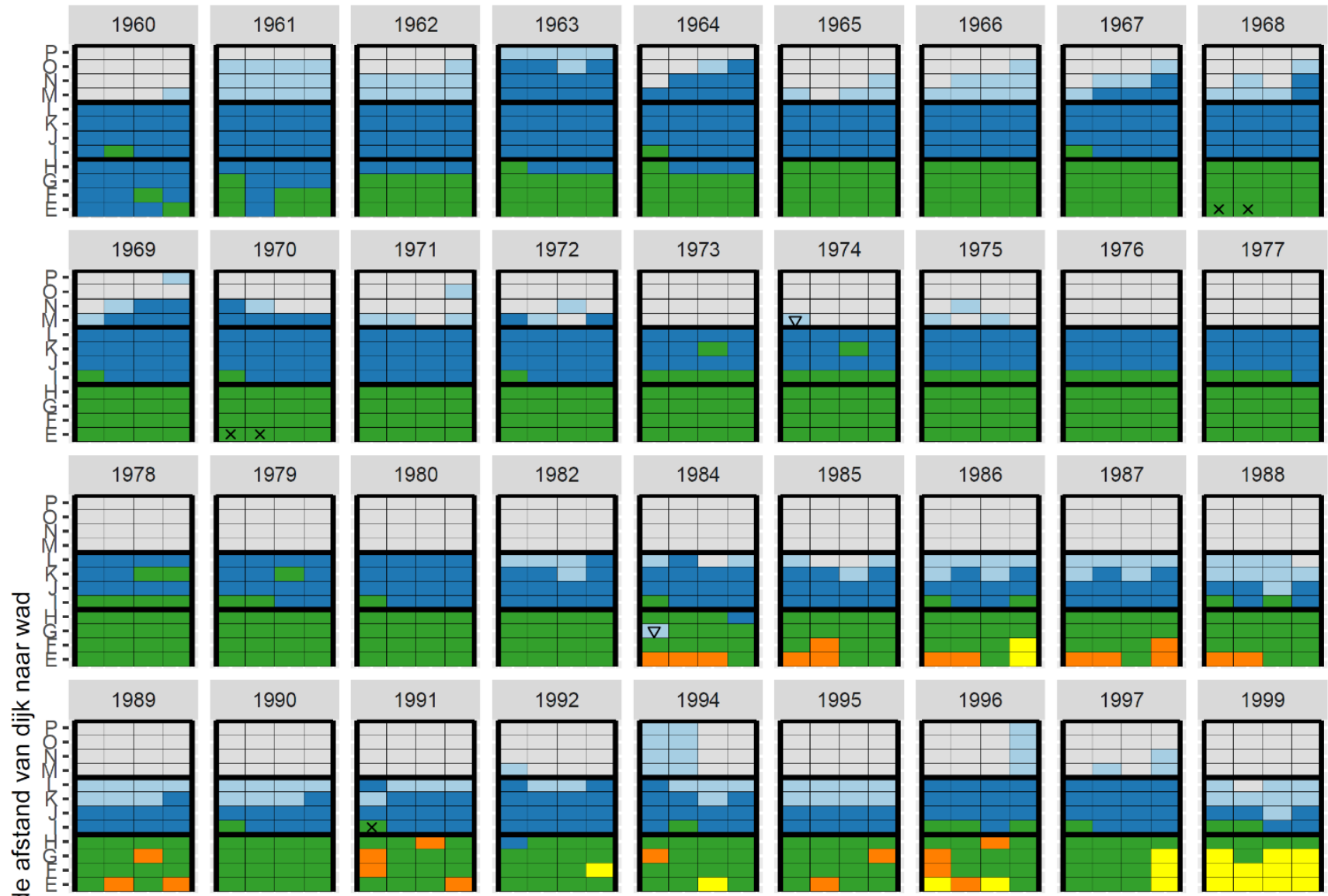

1999
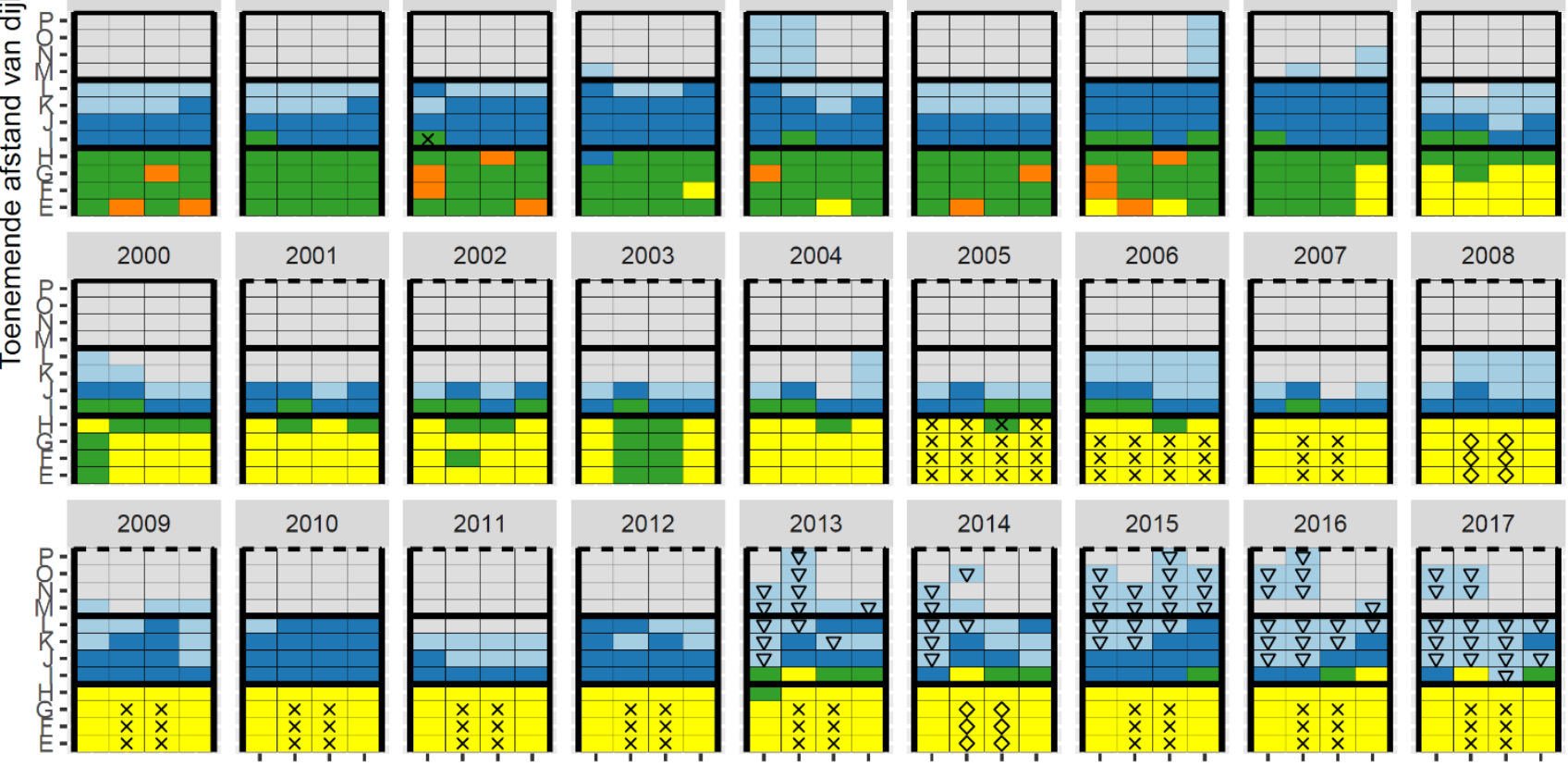

2018

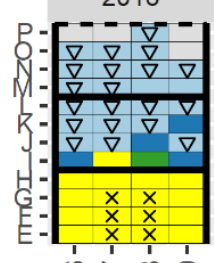

$\infty$

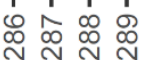

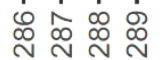

$\stackrel{\sim}{\sim} \stackrel{i}{\sim} \stackrel{\infty}{\sim} \stackrel{\infty}{\sim}$

$\stackrel{\sim}{\sim} \stackrel{\infty}{\sim} \stackrel{\infty}{\sim} \stackrel{\infty}{\sim}$

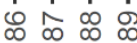

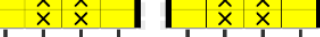

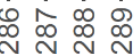

MeetVaknummer

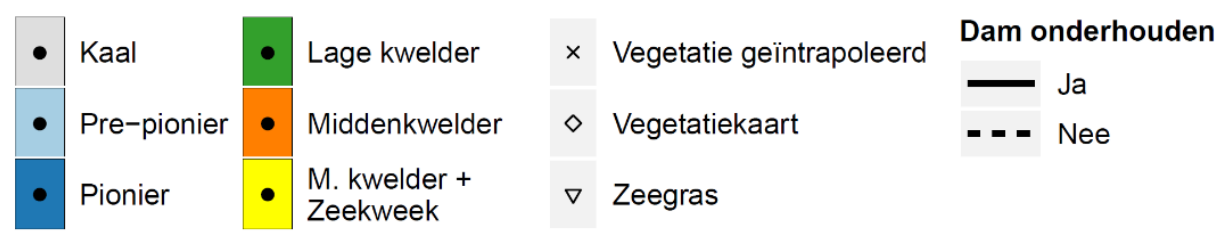


Groningen West: 308 - 311 (Negenboerenpolder)
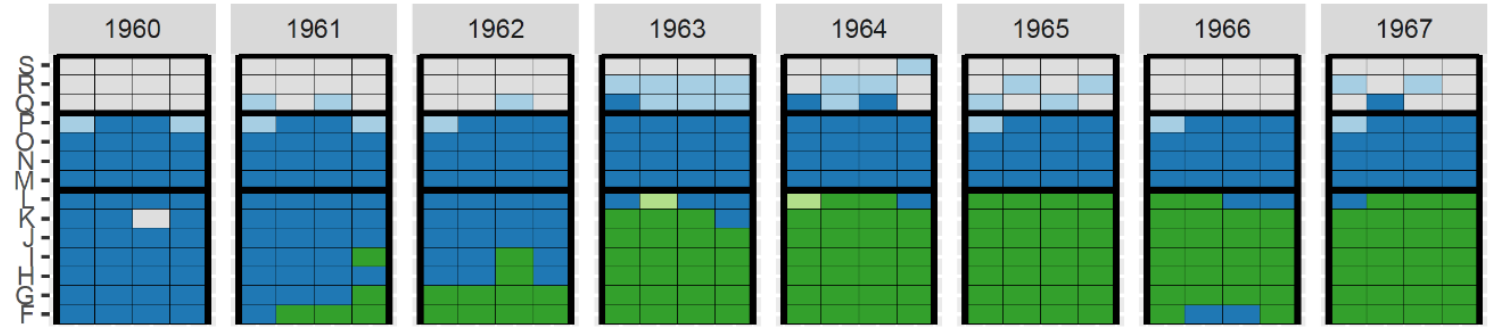

1968
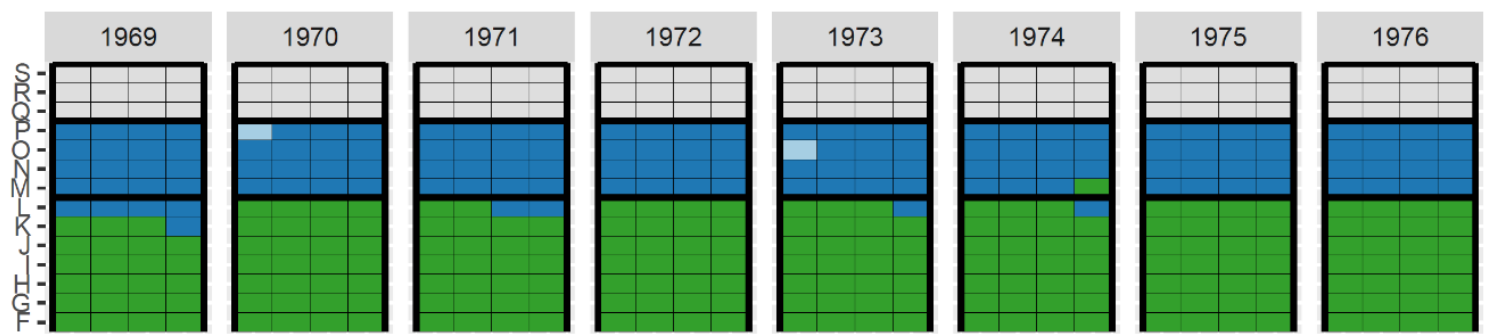

1977
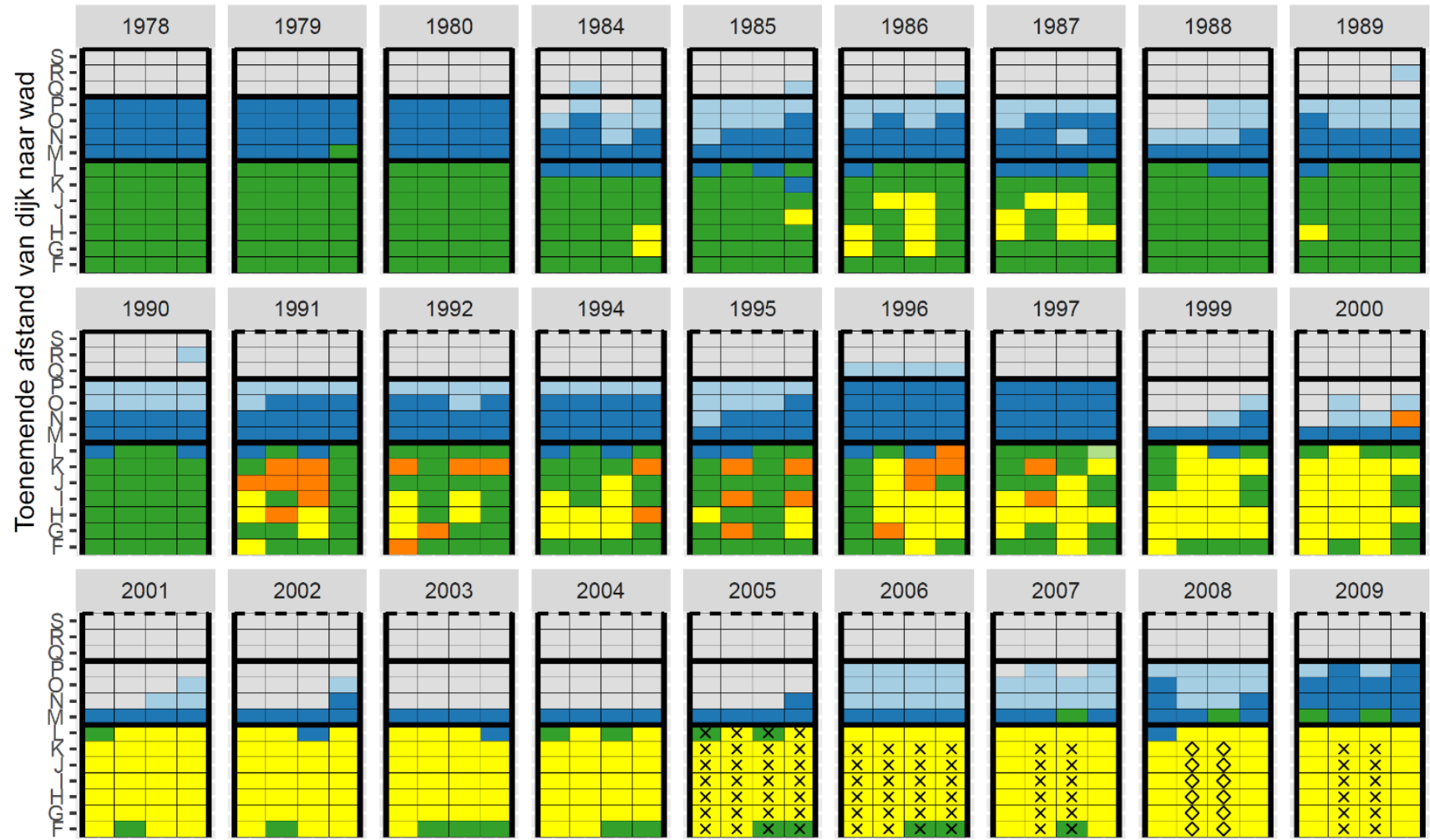

$$
2002
$$

2003

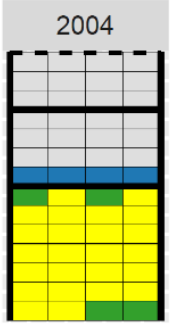

2005
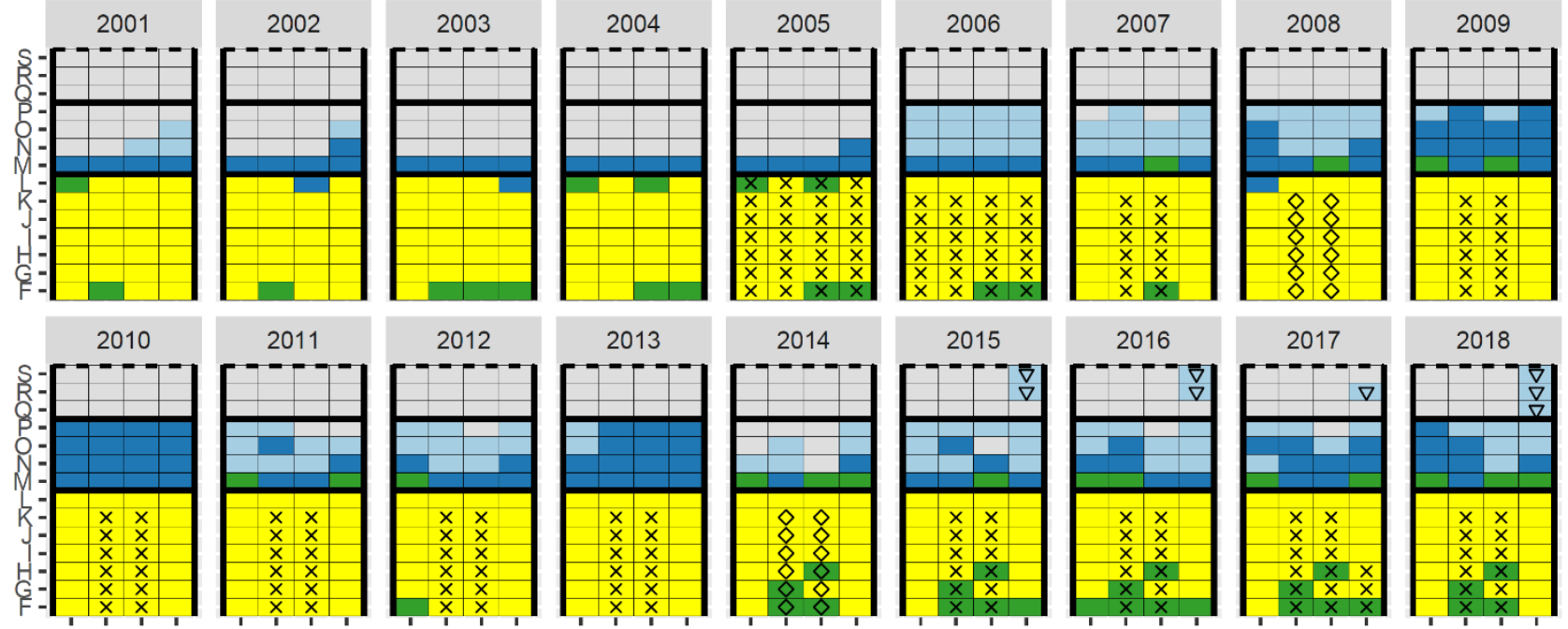

o 잉 응 둥

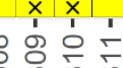

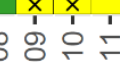

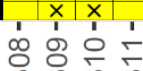

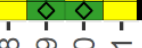

$\infty$ o은

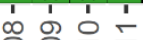

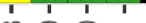

$1+1$ MeetVaknummer

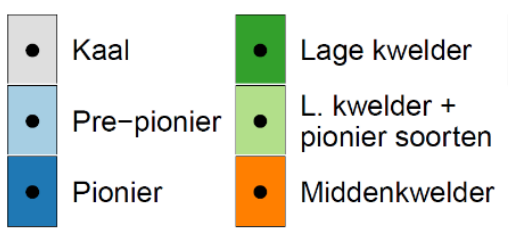

- M. kwelder +

$\times$ Vegetatie geïntrapoleerd

Dam onderhouden

Dam onderh

$\diamond$ Vegetatiekaart

Ja

$\nabla \quad$ Zeegras 
Groningen West: 324 - 327 (Negenboerenpolder)
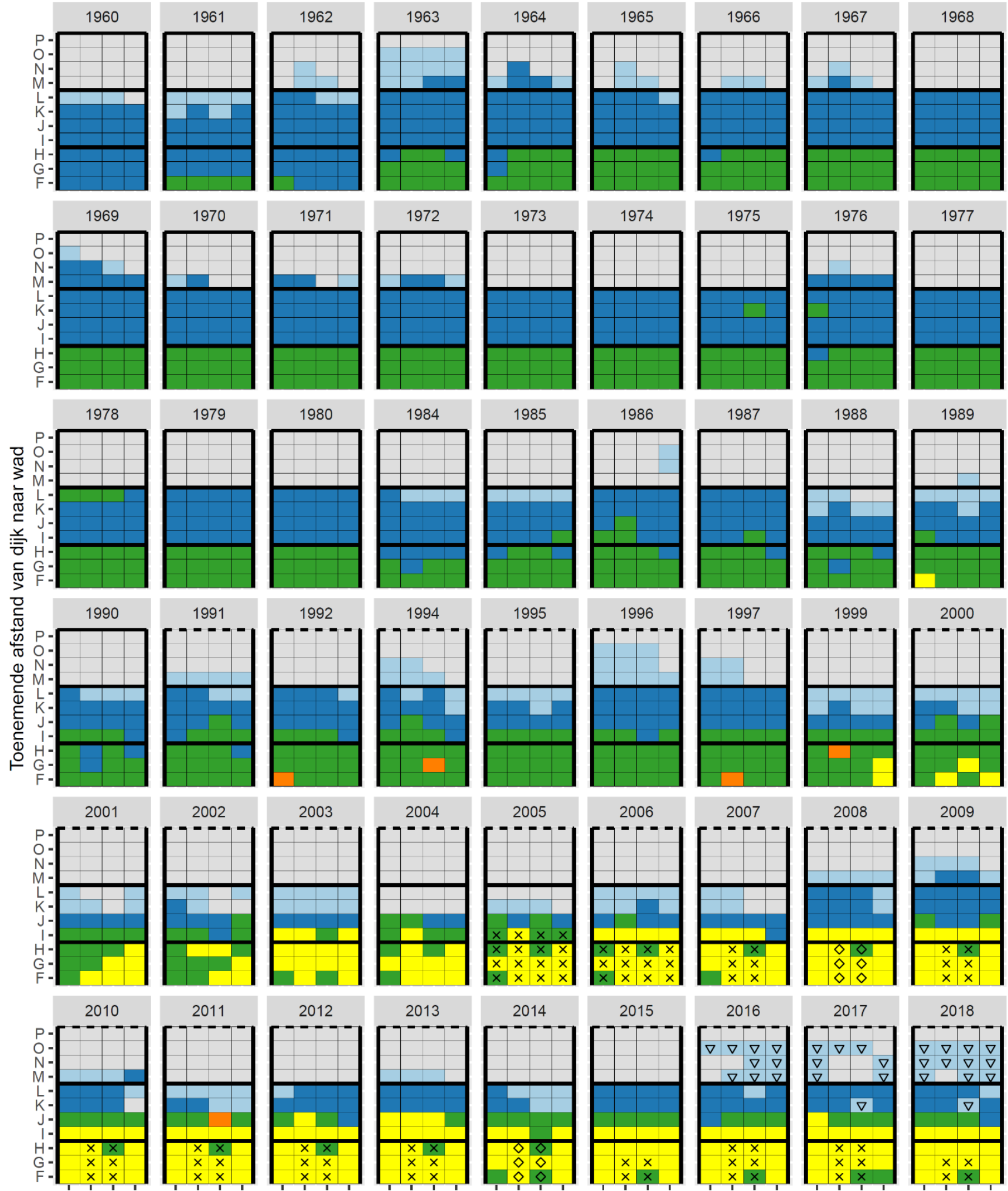

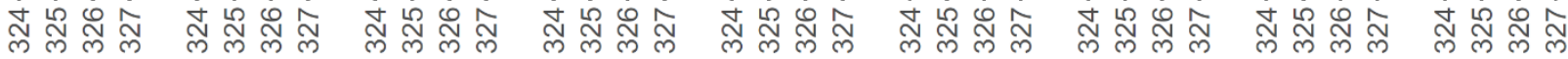
MeetVaknummer

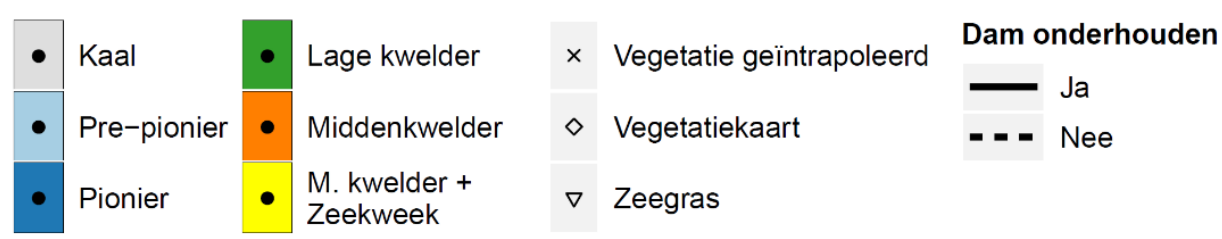


Groningen Midden: 337 - 339 (Negenboerenpolder)
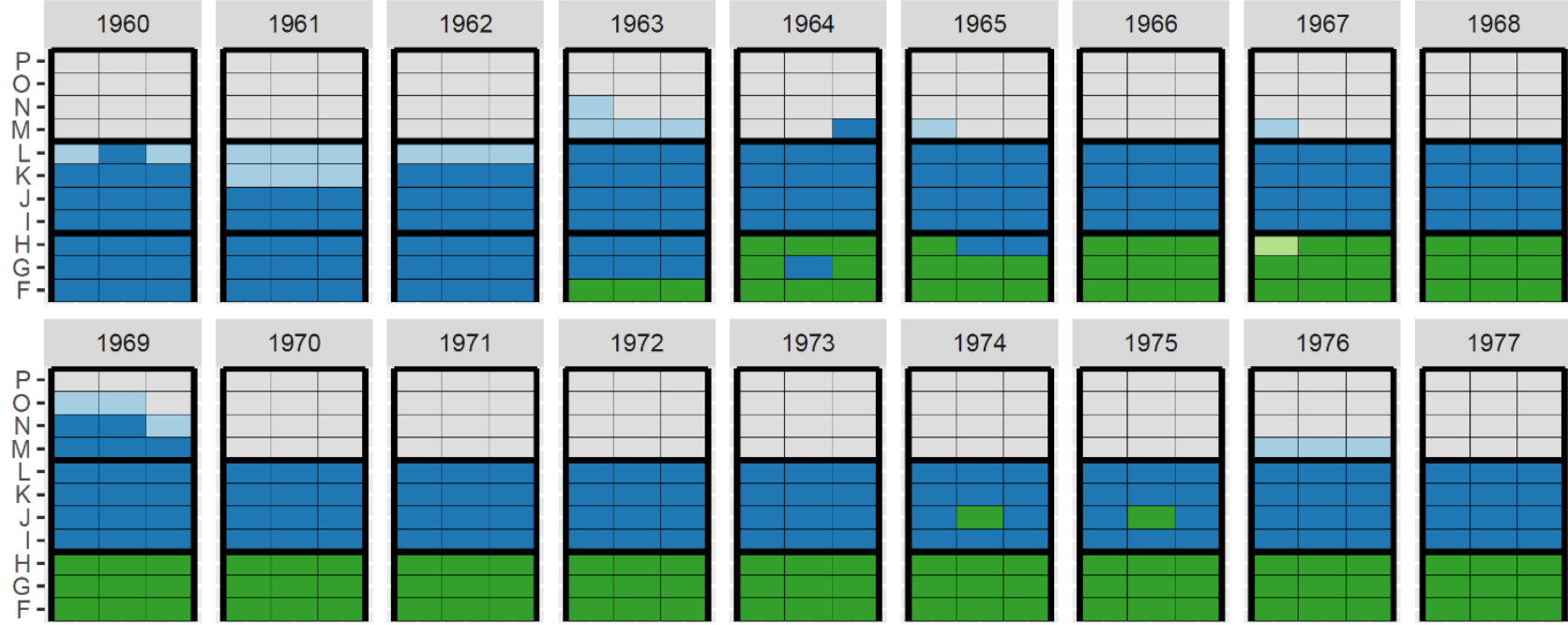

1977
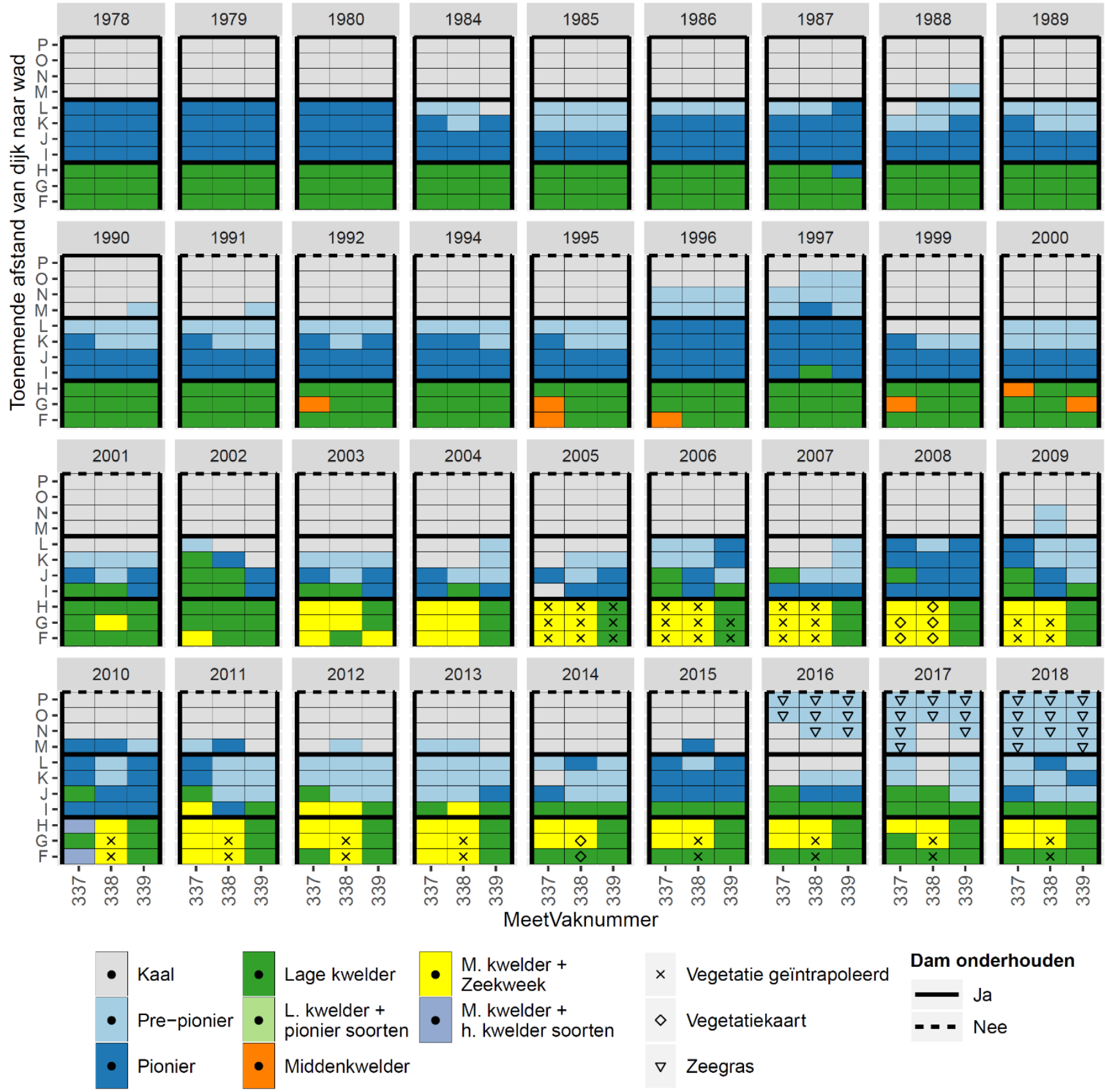

- M. kwelder +

- Zeekweek

- M. kwelder +

h. kwelder soorten

$\times \quad$ Vegetatie geïntrapoleerd

Dam onderhouden

$\diamond$ Vegetatiekaart

- Ja

$\nabla \quad$ Zeegras

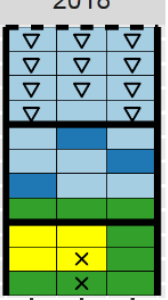

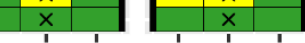
MeetVaknummer 
Groningen Midden: 356 - 359 (Linthorst Homanpolder)
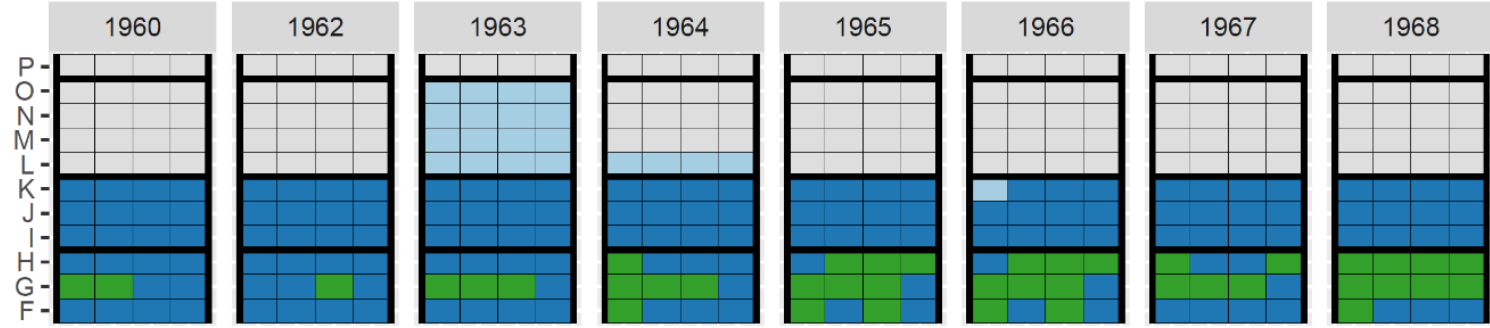

1969

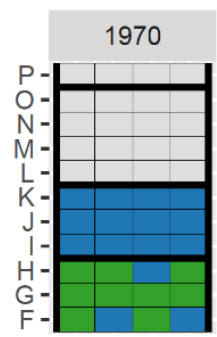

1971

1972

1973

1974

1975

1976

1977
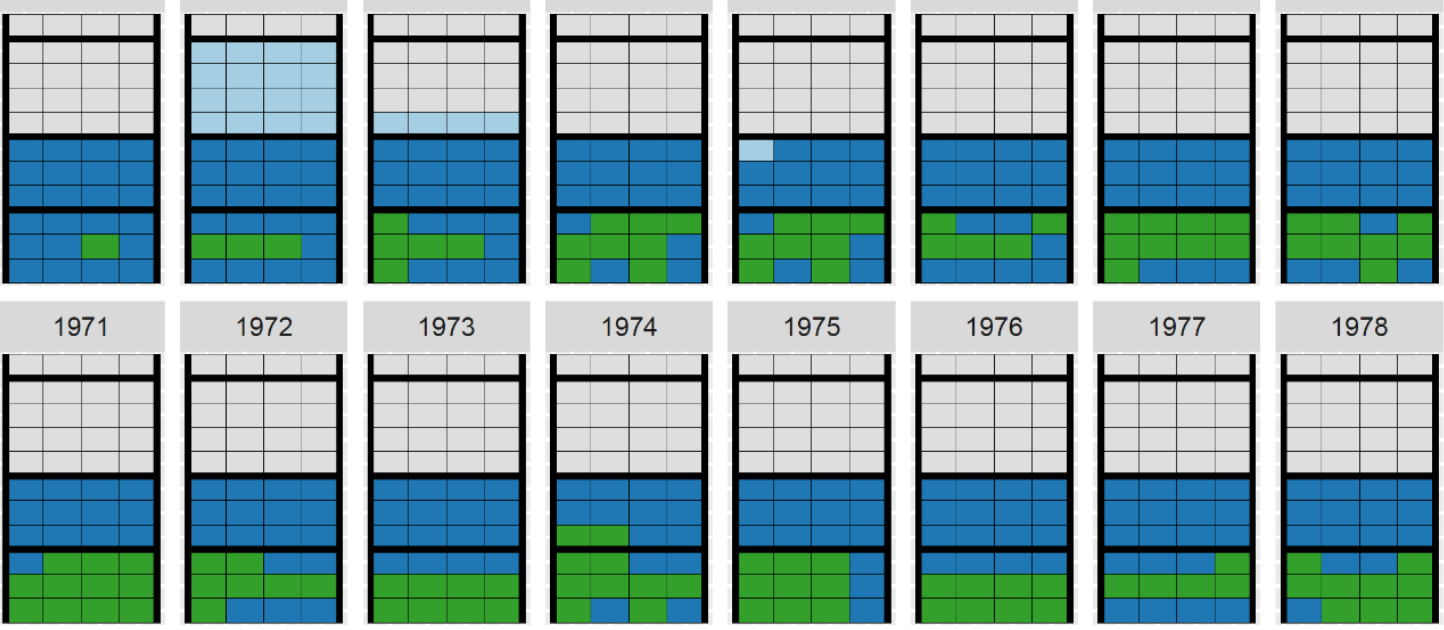

1978
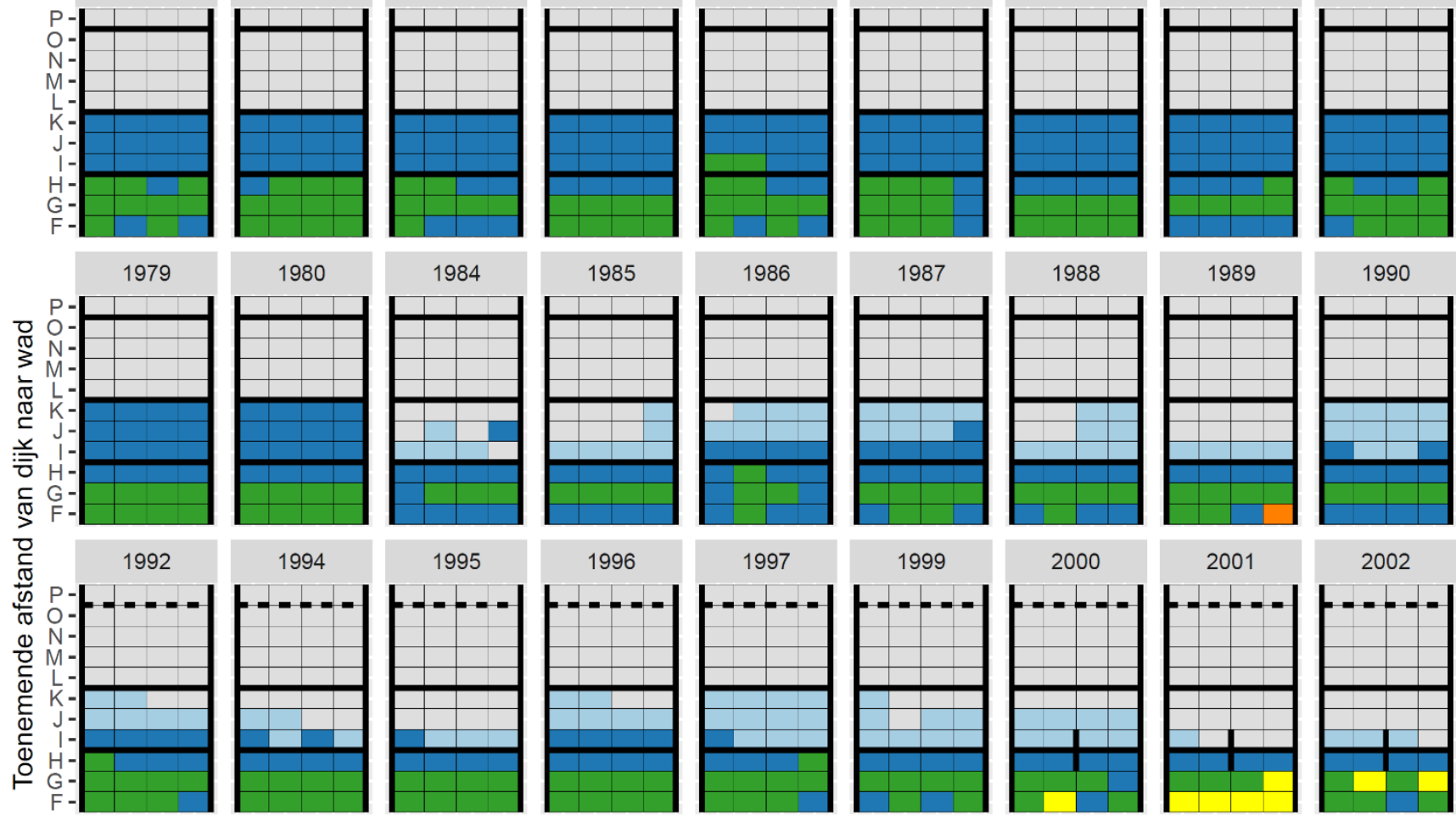

2001
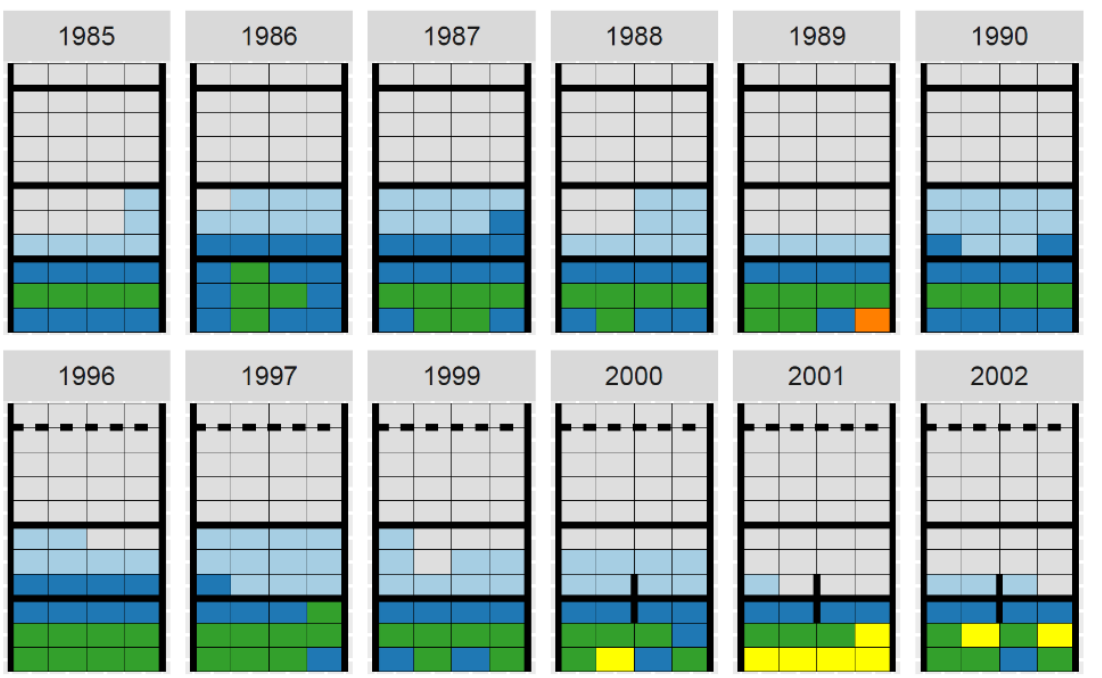

2002
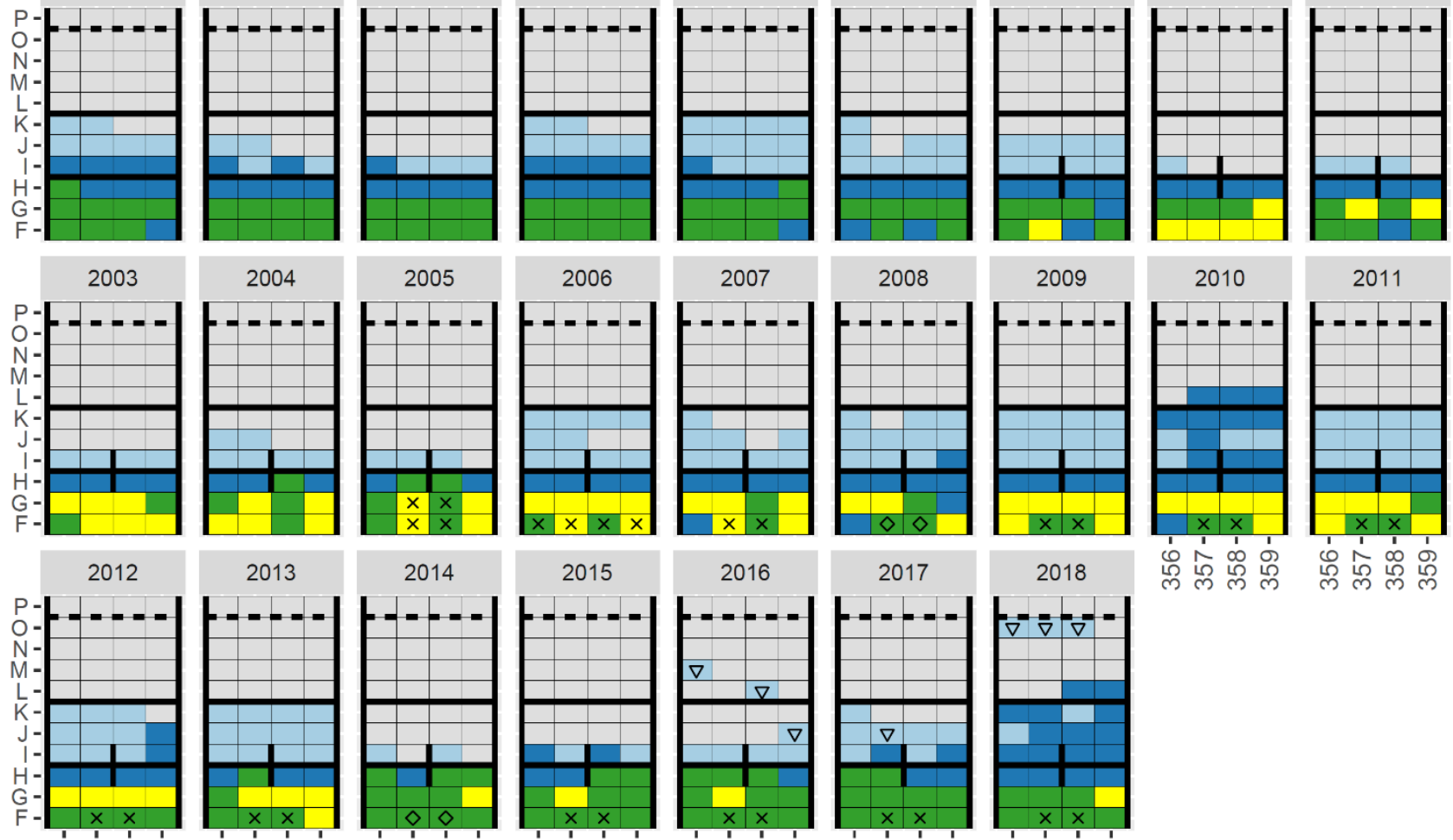

$$
2013
$$

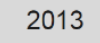

$$
2014
$$
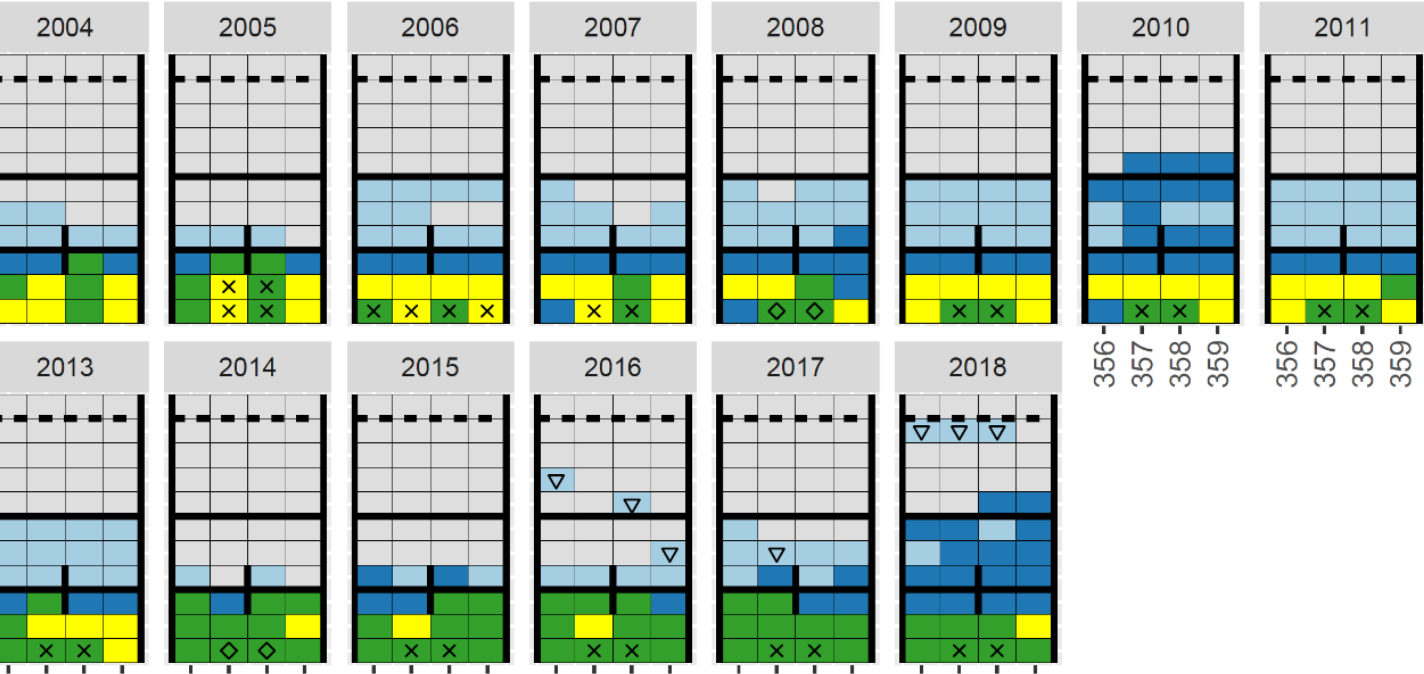

2018

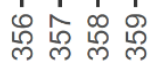
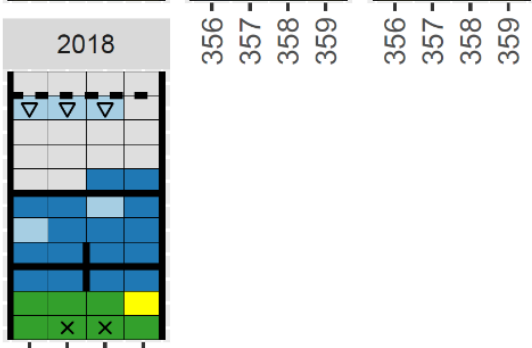

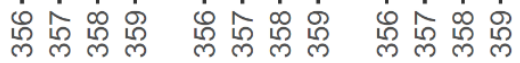

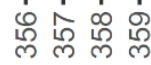

MeetVaknummer

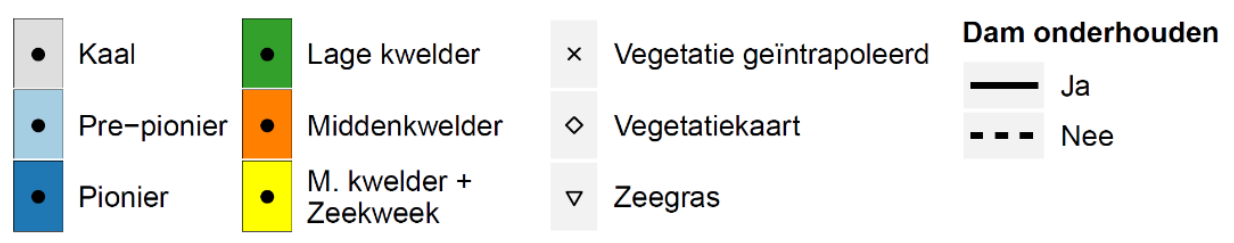


Groningen Midden: 372 - 375 (Linthorst Homanpolder)
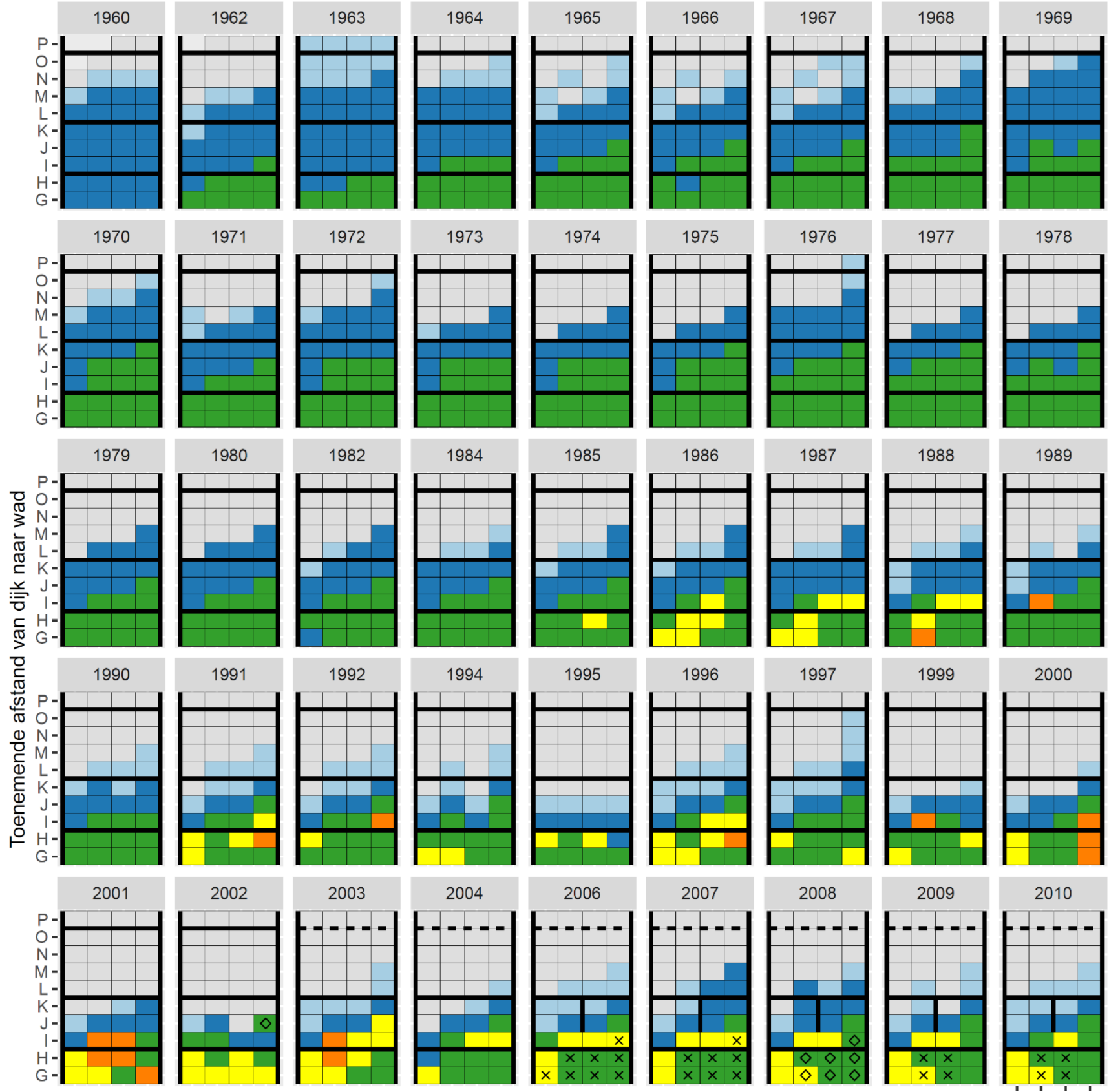

2002
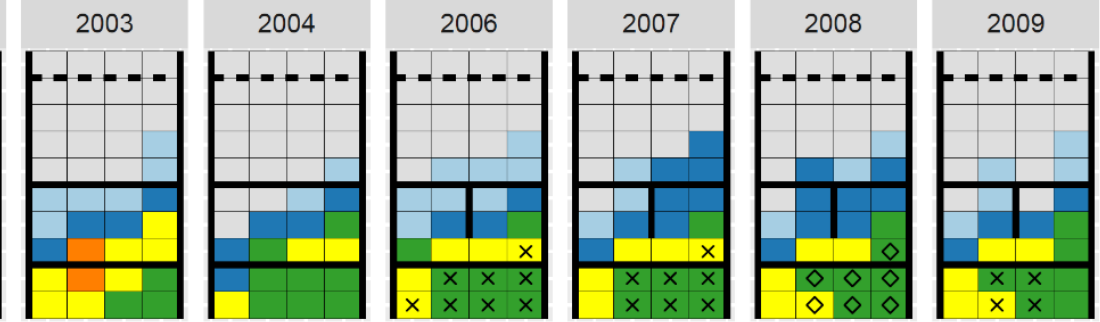

2010
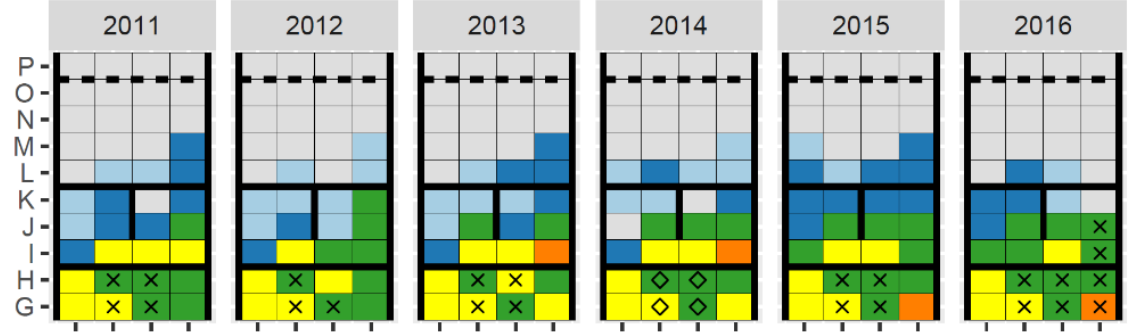

2017

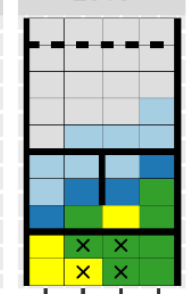

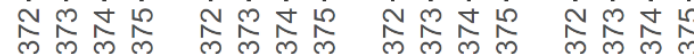
MeetVaknummer

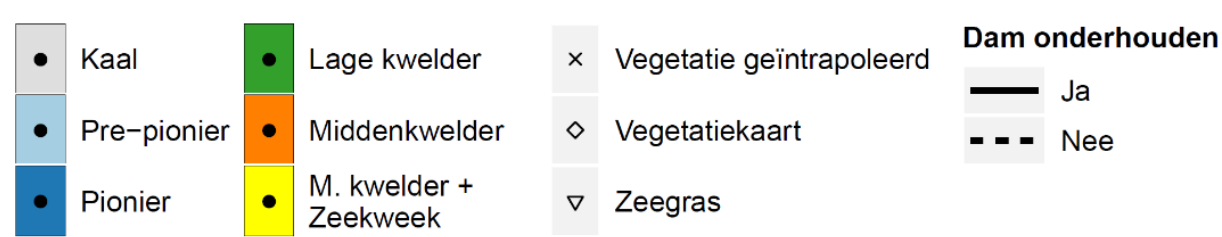


Groningen Midden: 392 - 395 (Linthorst Homanpolder)
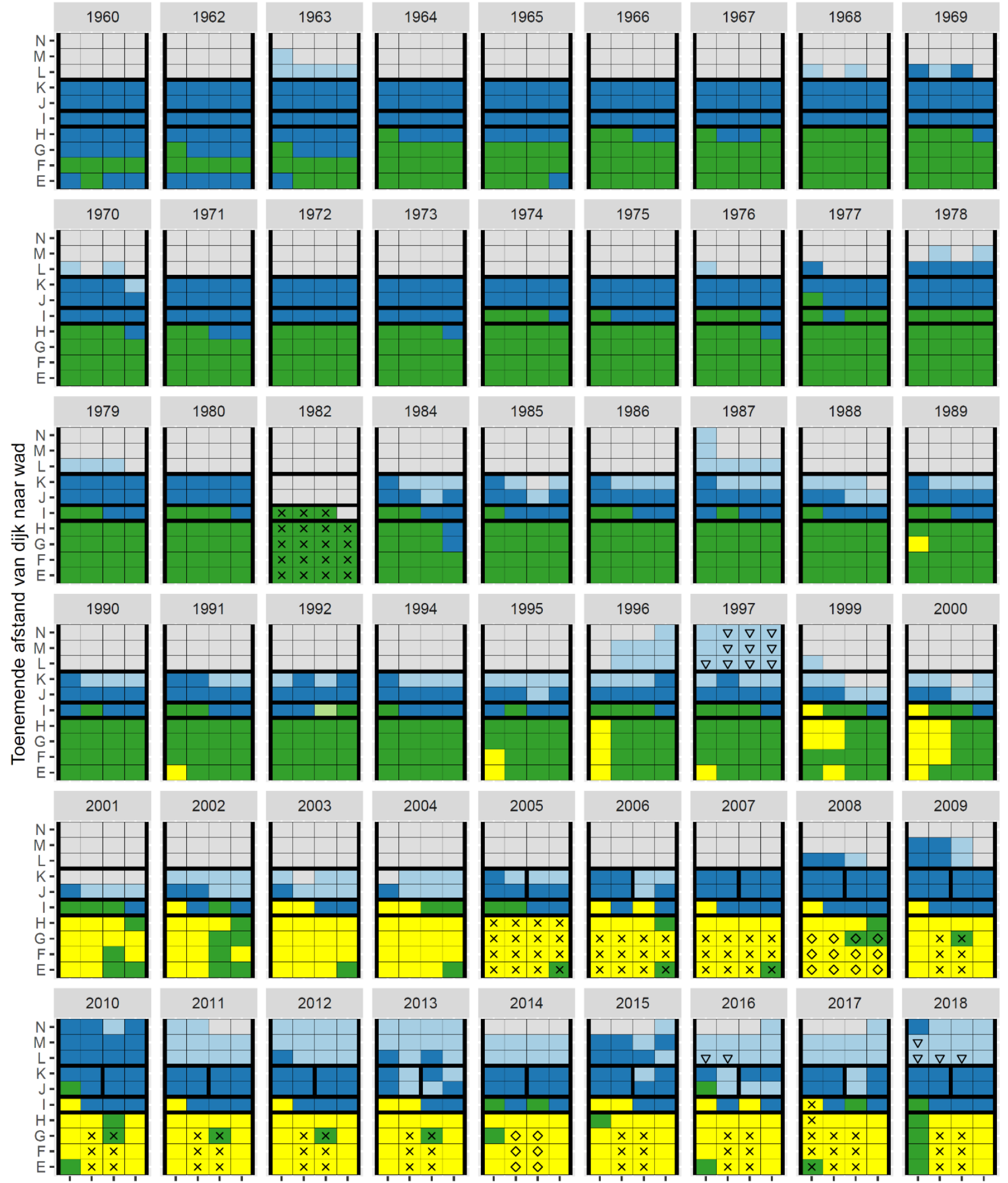

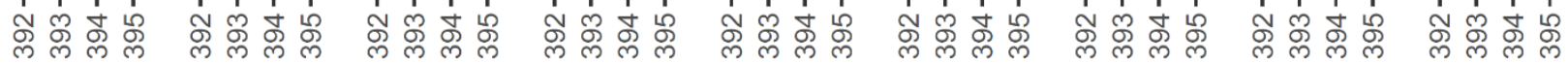
MeetVaknummer

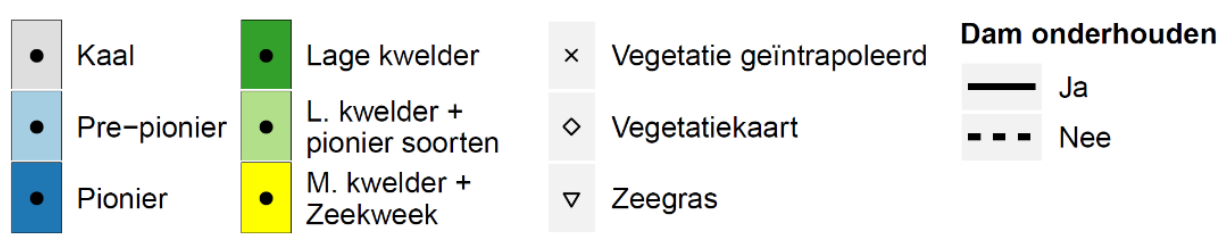


Groningen Oost: 412 - 415 (Noordpolder)
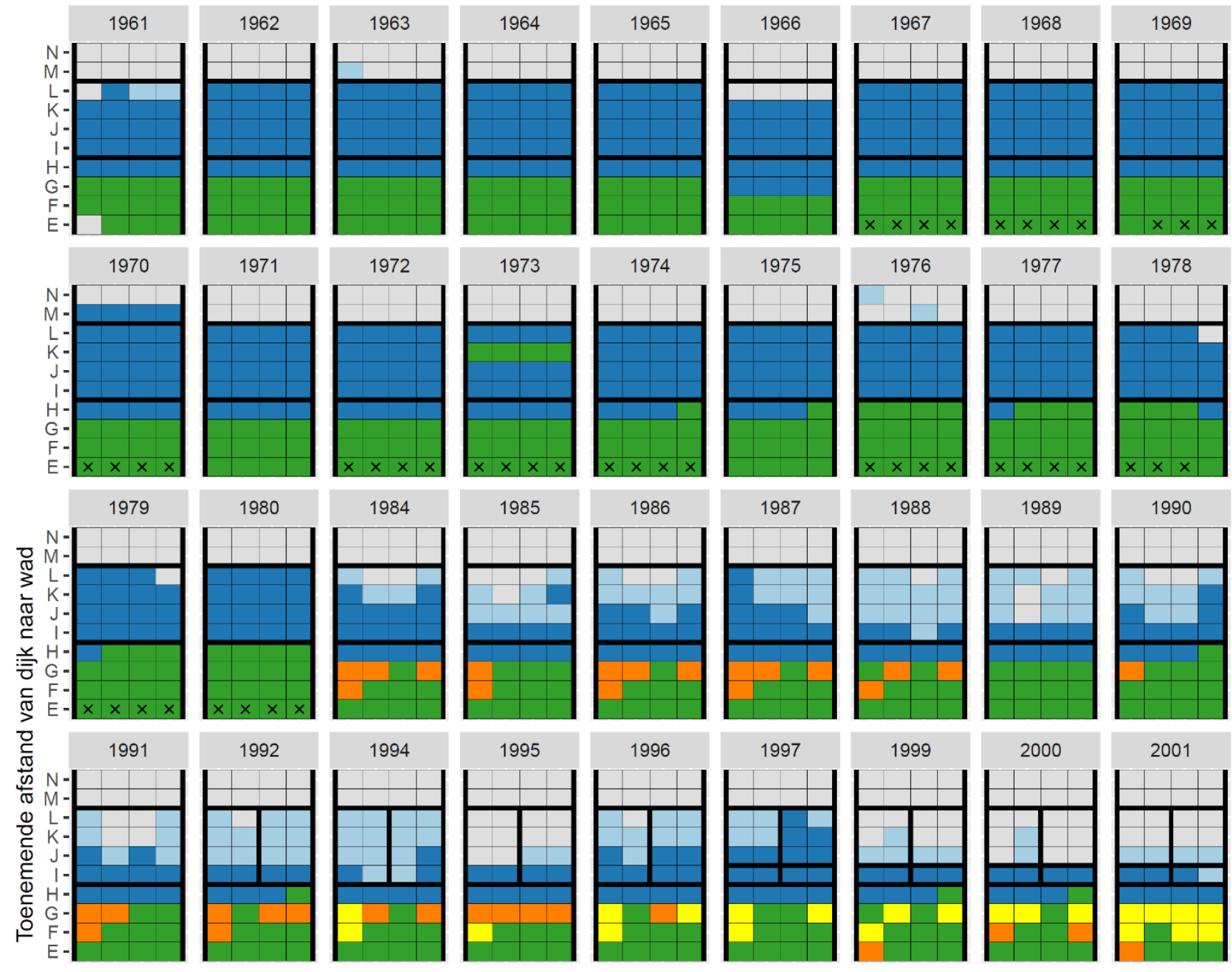

2001
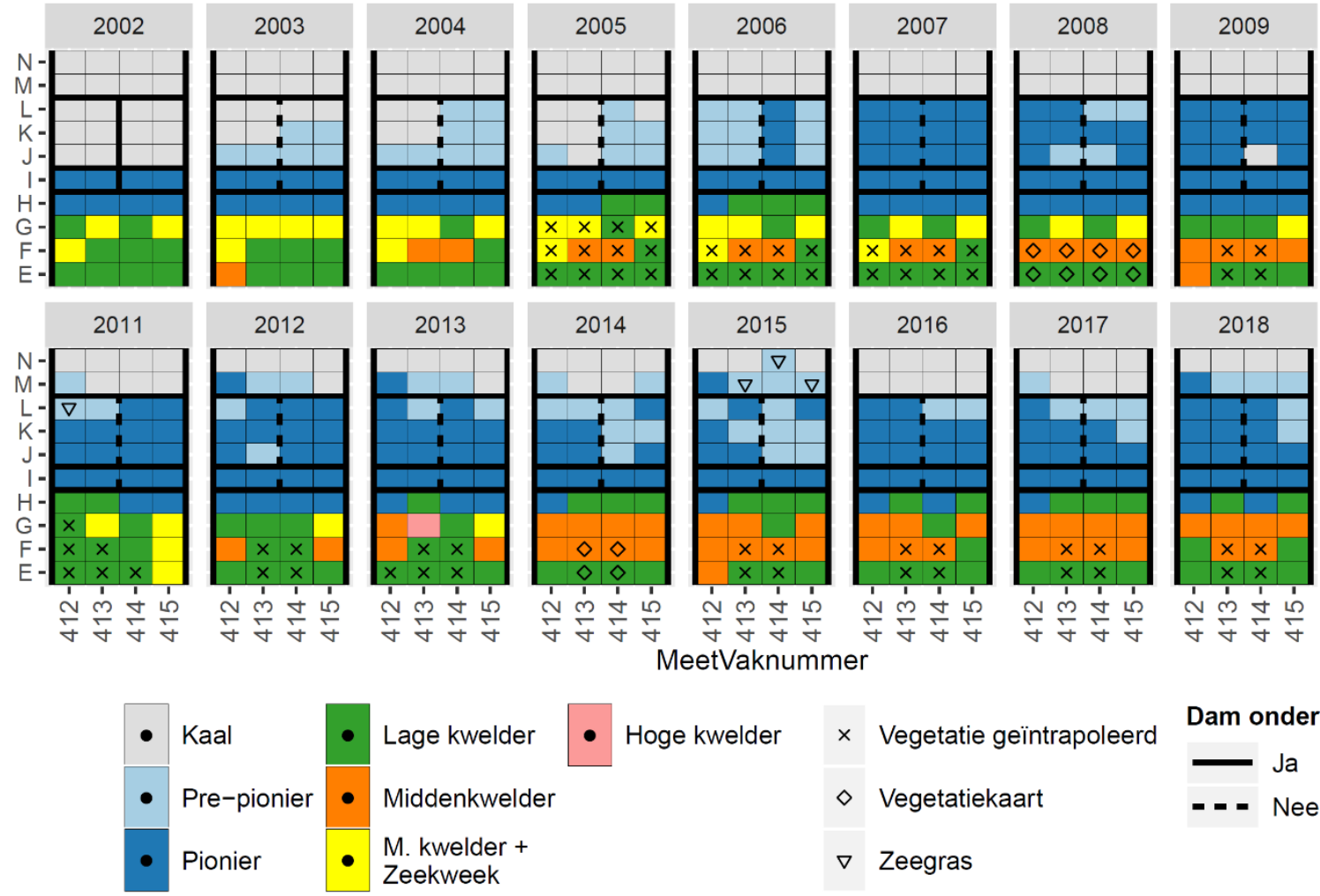

- Hoge kwelder

$\times \quad$ Vegetatie geïntrapoleerd

Dam onderhouden

$\diamond$ Vegetatiekaart

Ja

$\nabla$ Zeegras 
Groningen Oost: 428 - 431 (Noordpolder)
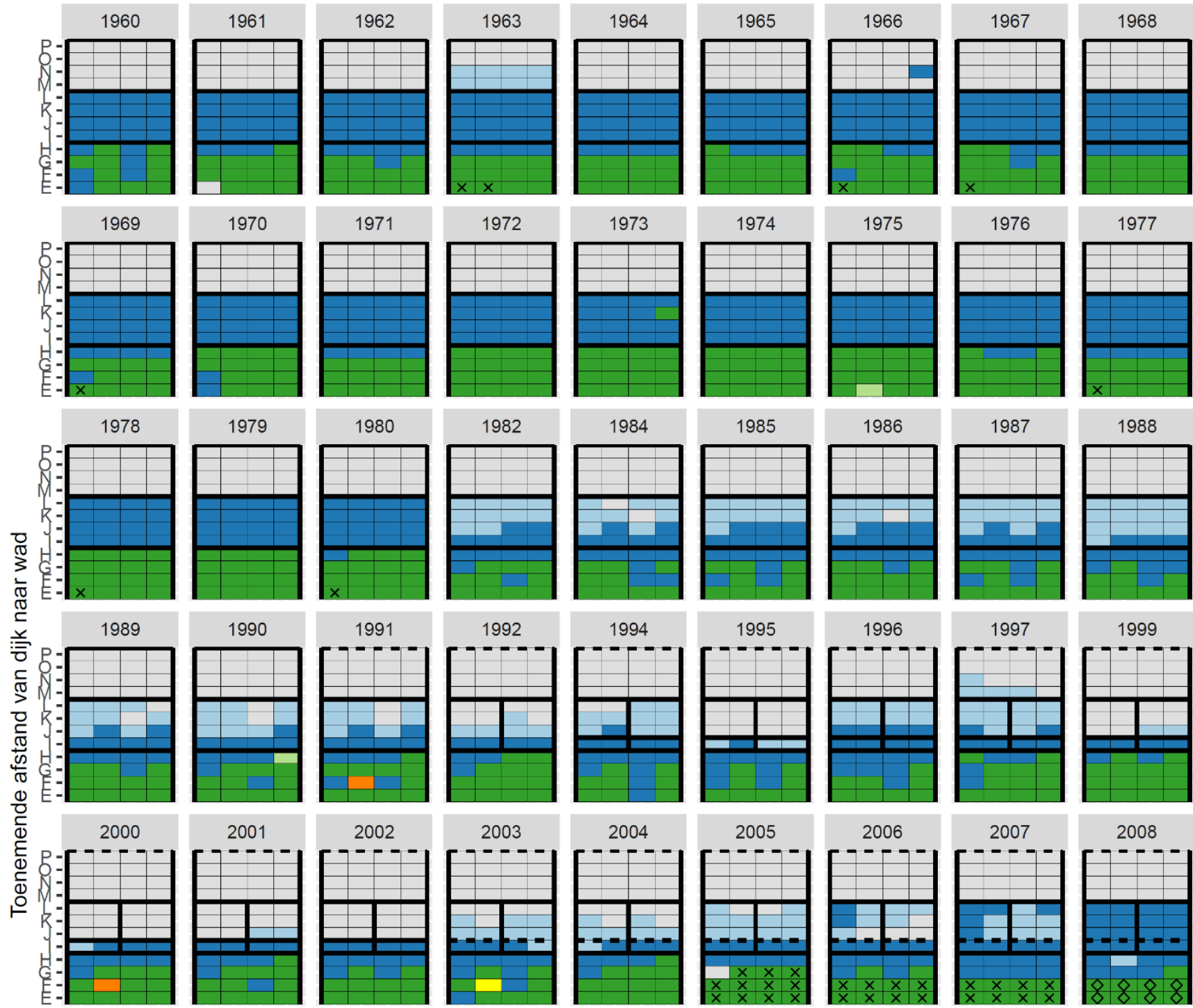

1999

20012002

2003

2004

2005

2006

2007
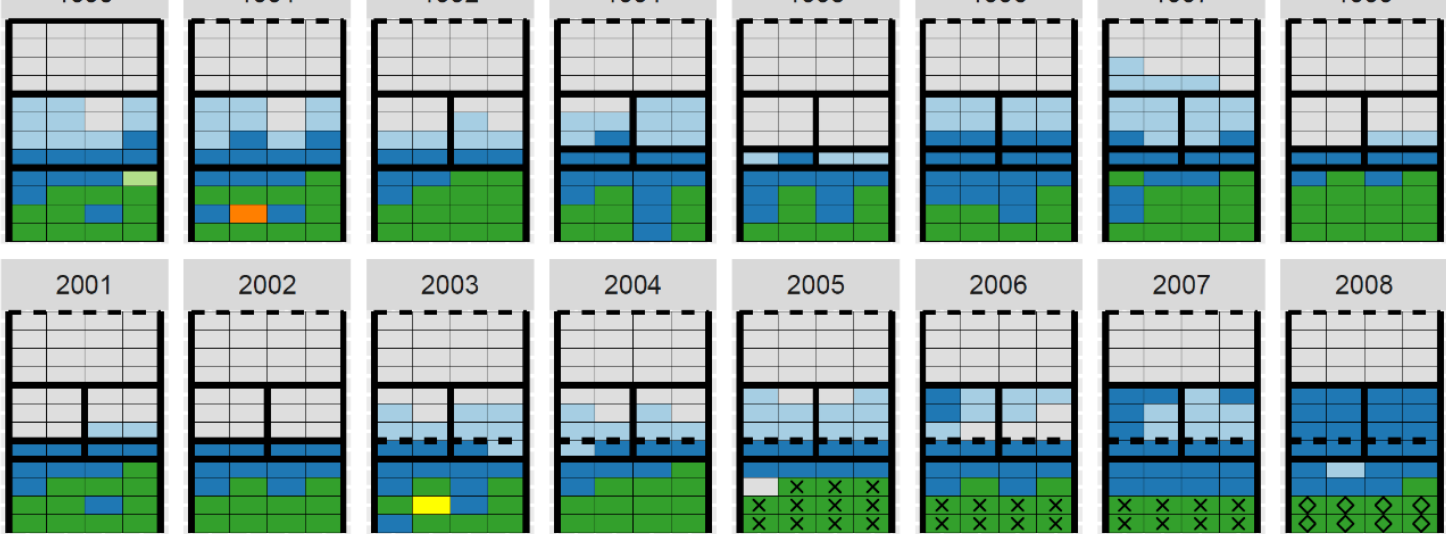

2008
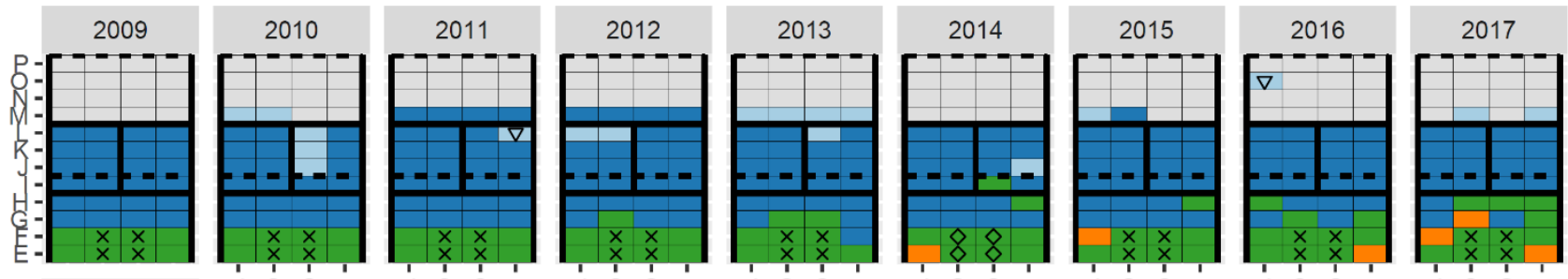

2018

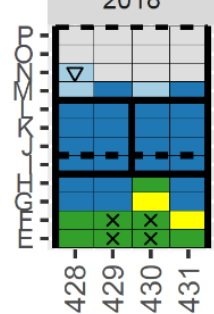

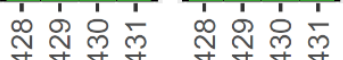

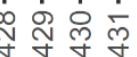

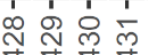

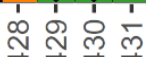

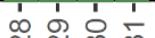

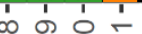

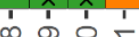
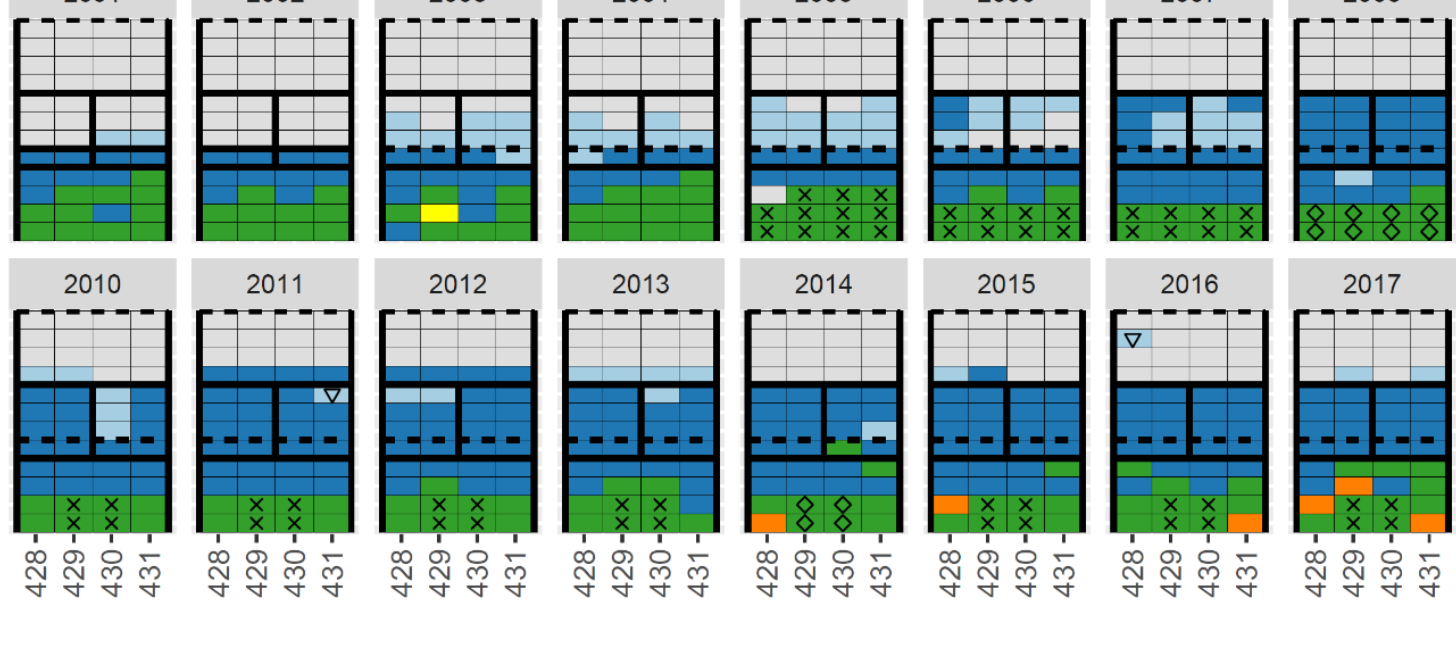

MeetVaknummer

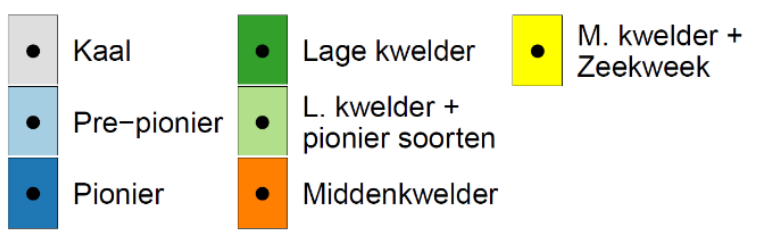

\footnotetext{
$\times \quad$ Vegetatie geïntrapoleerd

$\diamond$ Vegetatiekaart

$\nabla$ Zeegras
}

Dam onderhouden

- Ja

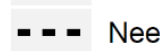


Groningen Oost: 448 - 451 (Noordpolder)
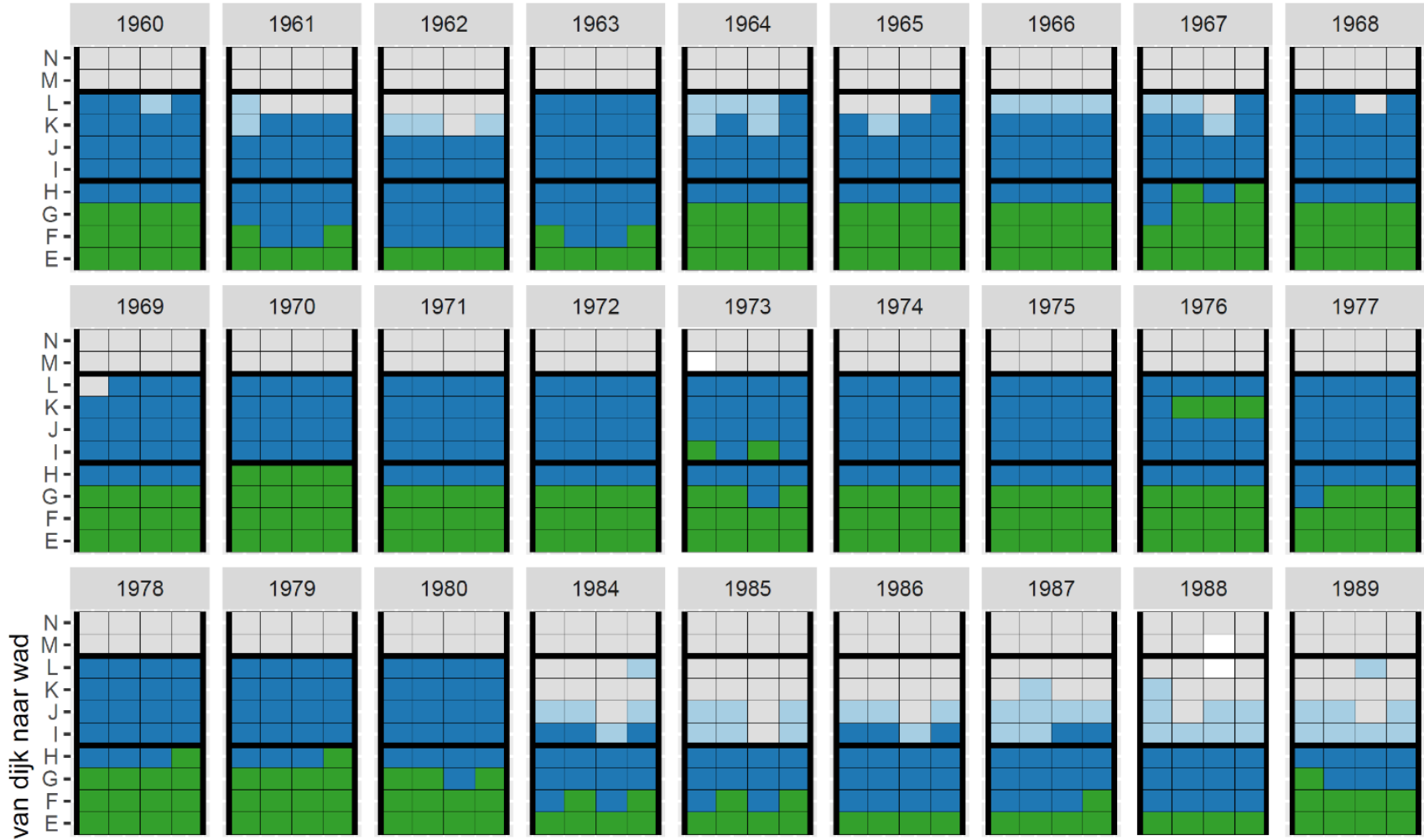

1989
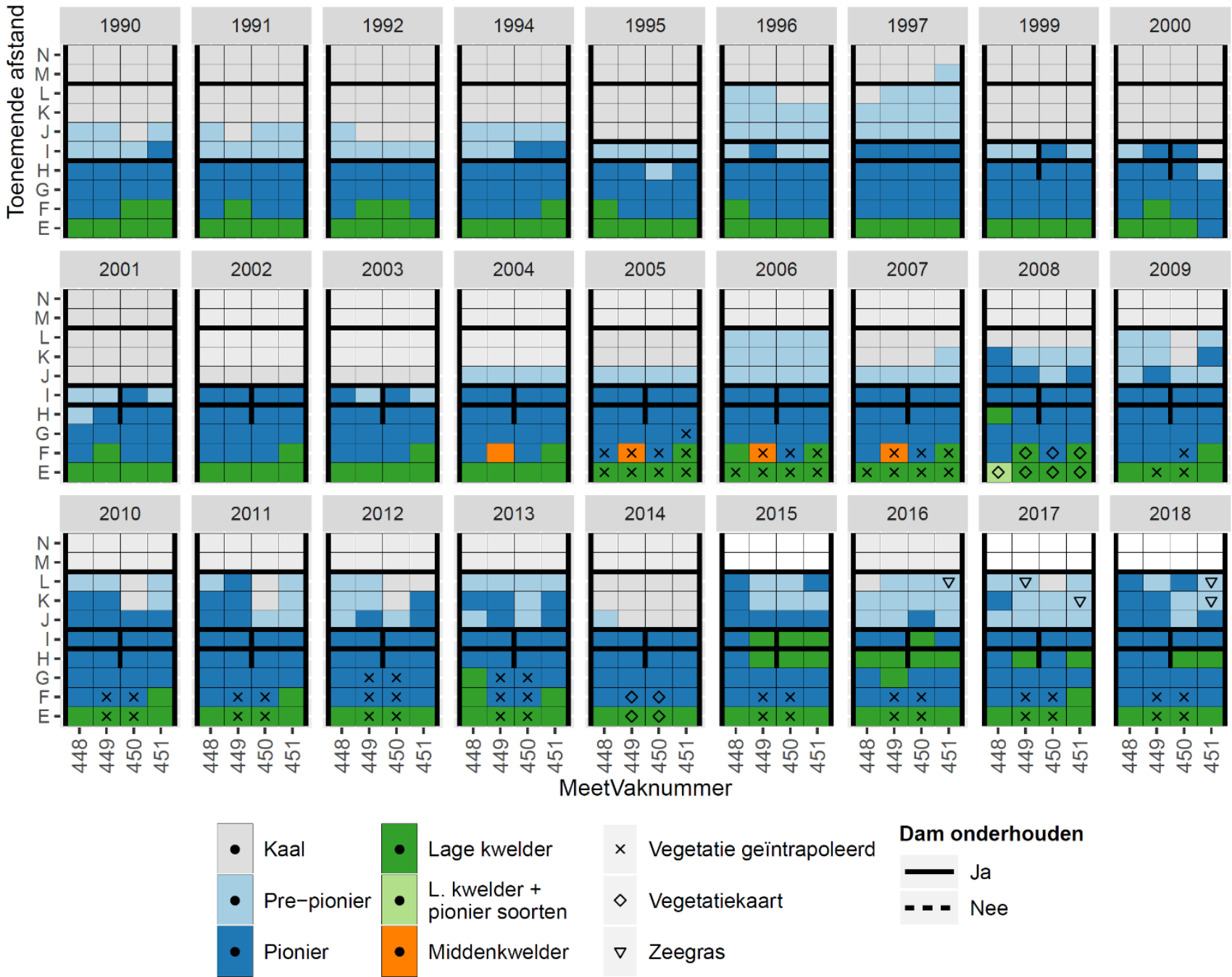
Groningen Oost: 468 - 471 (Lauwerspolder)
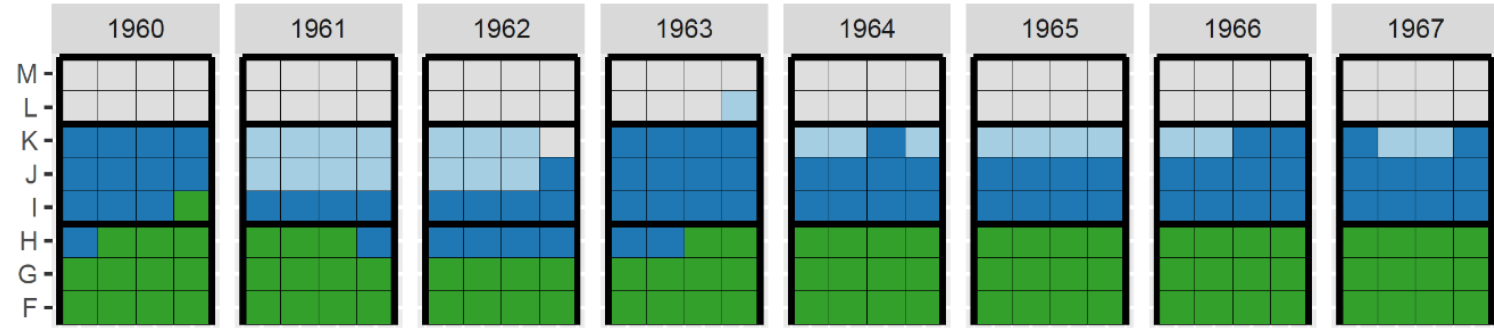

1968

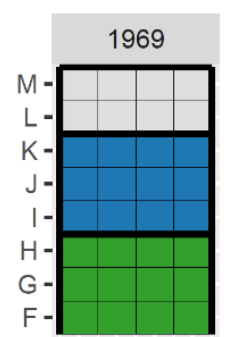

1970

1971

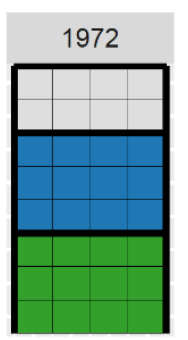

1973

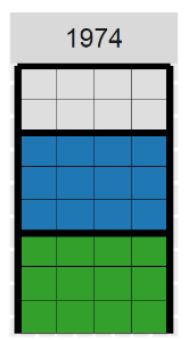

1975

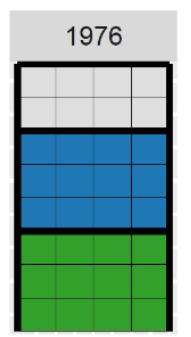

1977
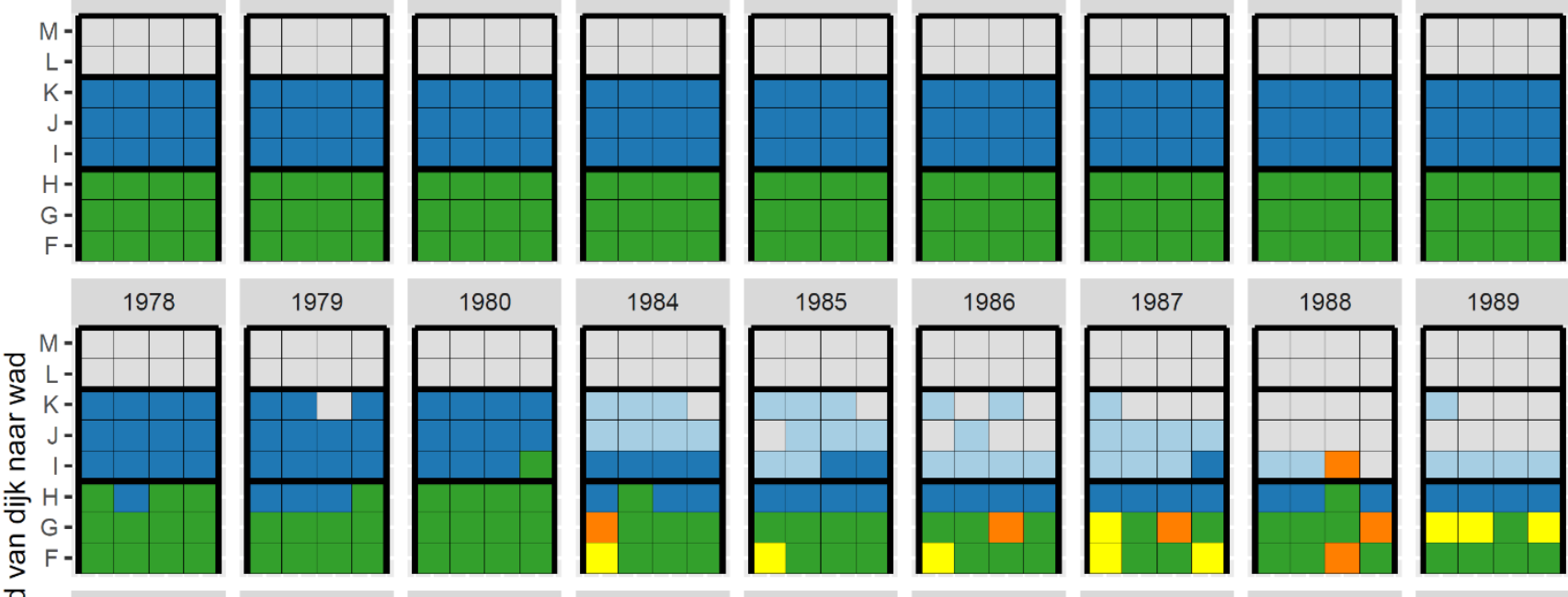

1989
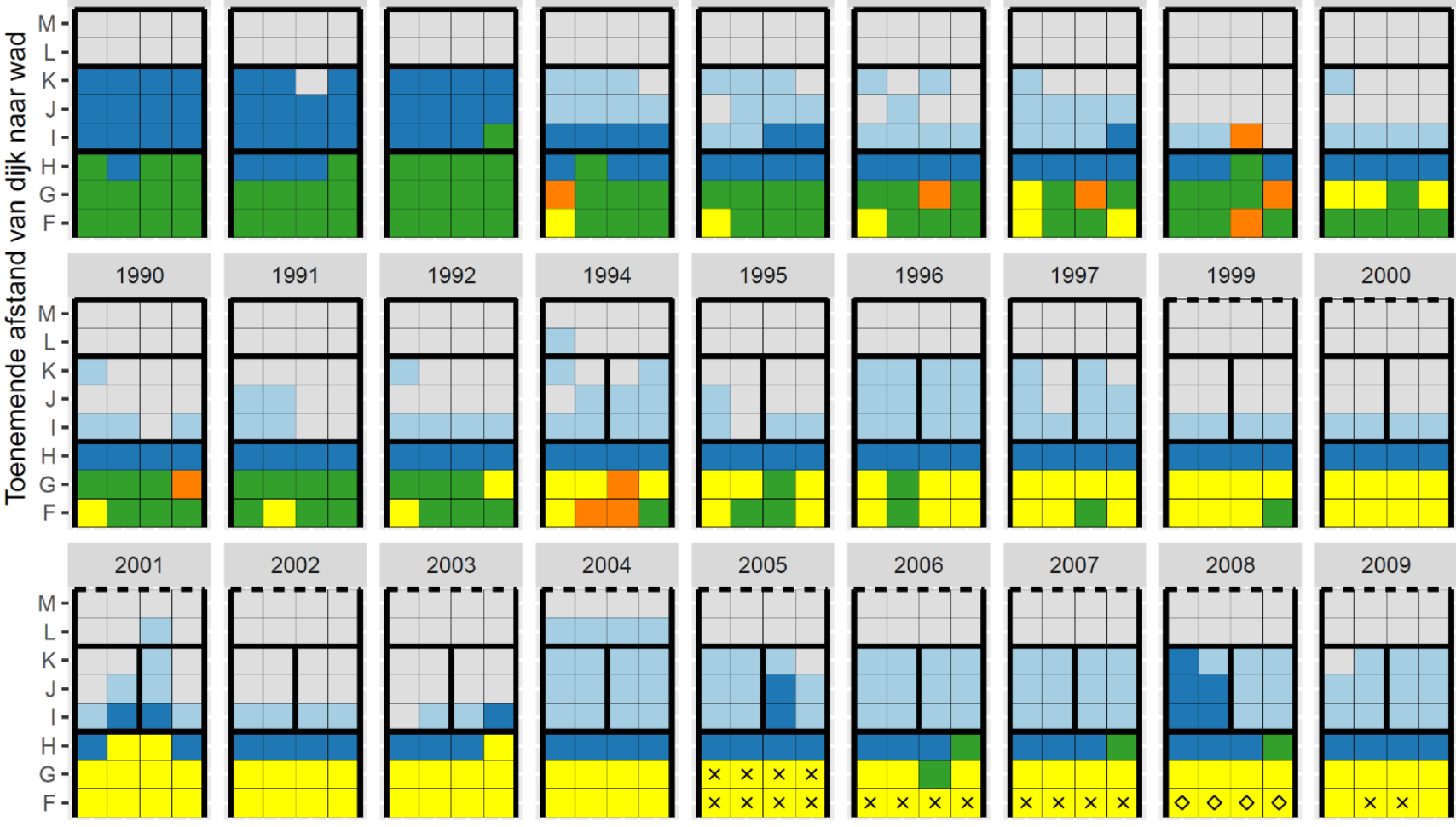

2008
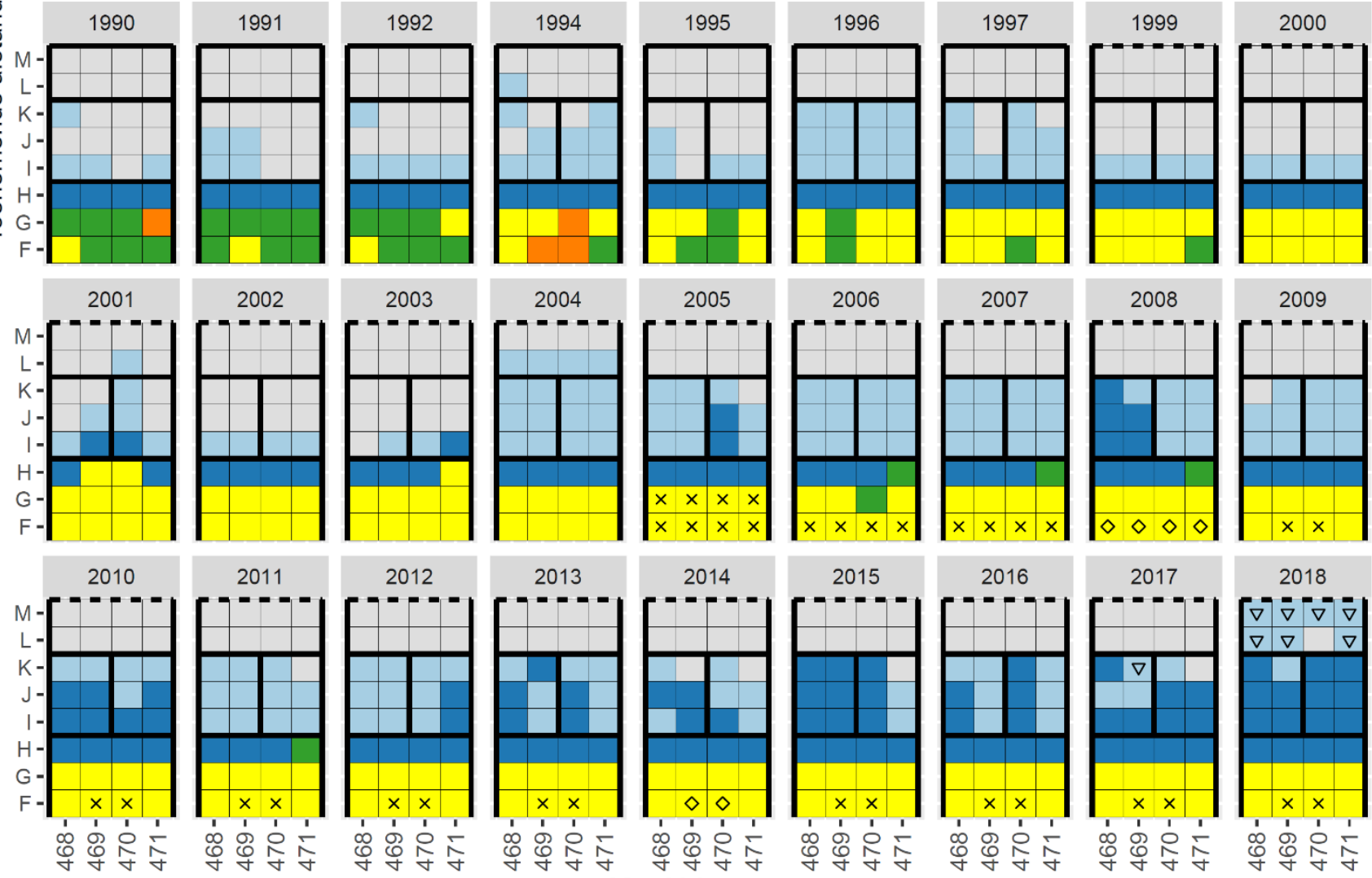

2009

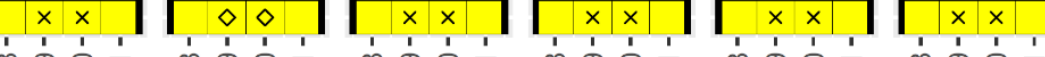
MeetVaknummer

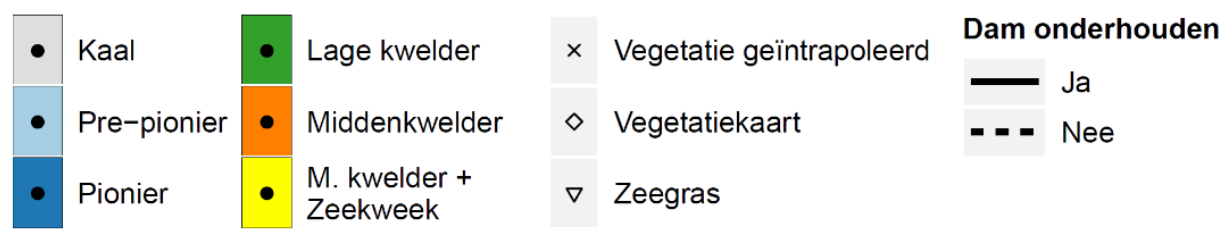


Groningen Oost: 488 - 491 (Lauwerspolder)
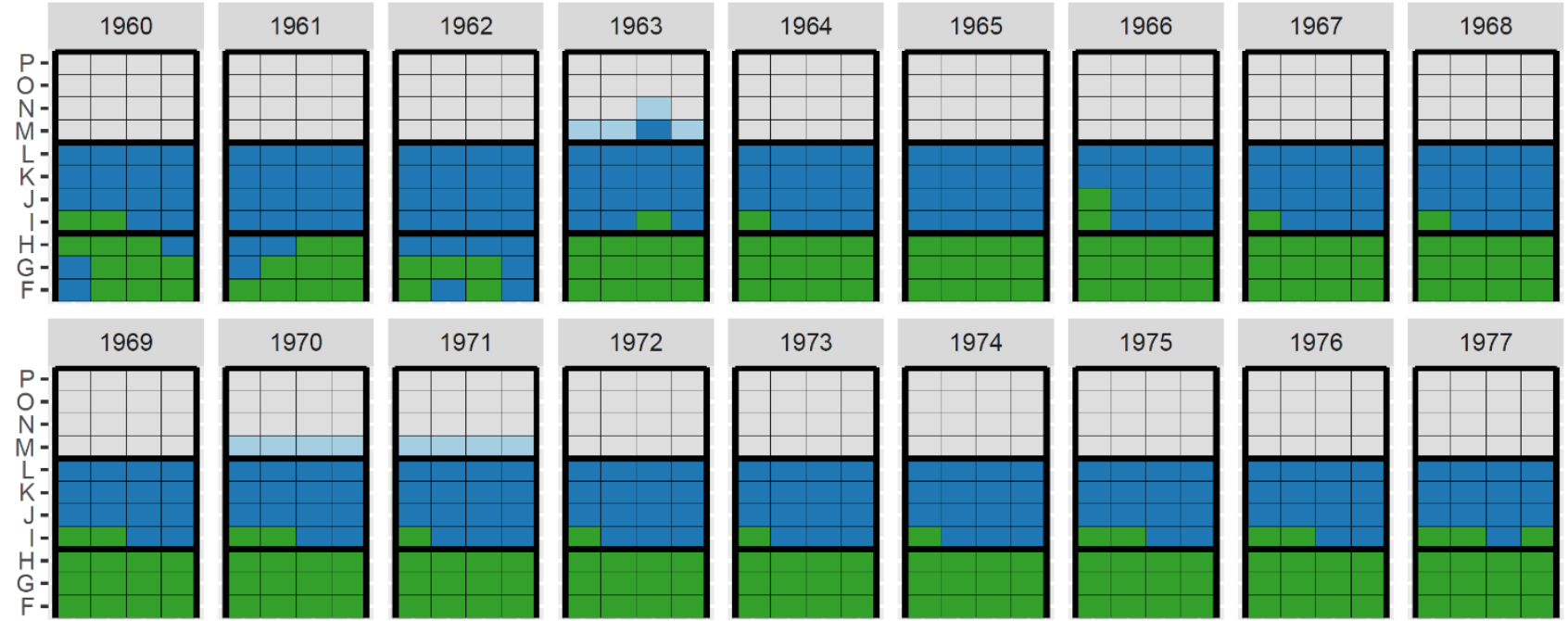

1970

1971

1972

1973

1974

1975

1976

1977
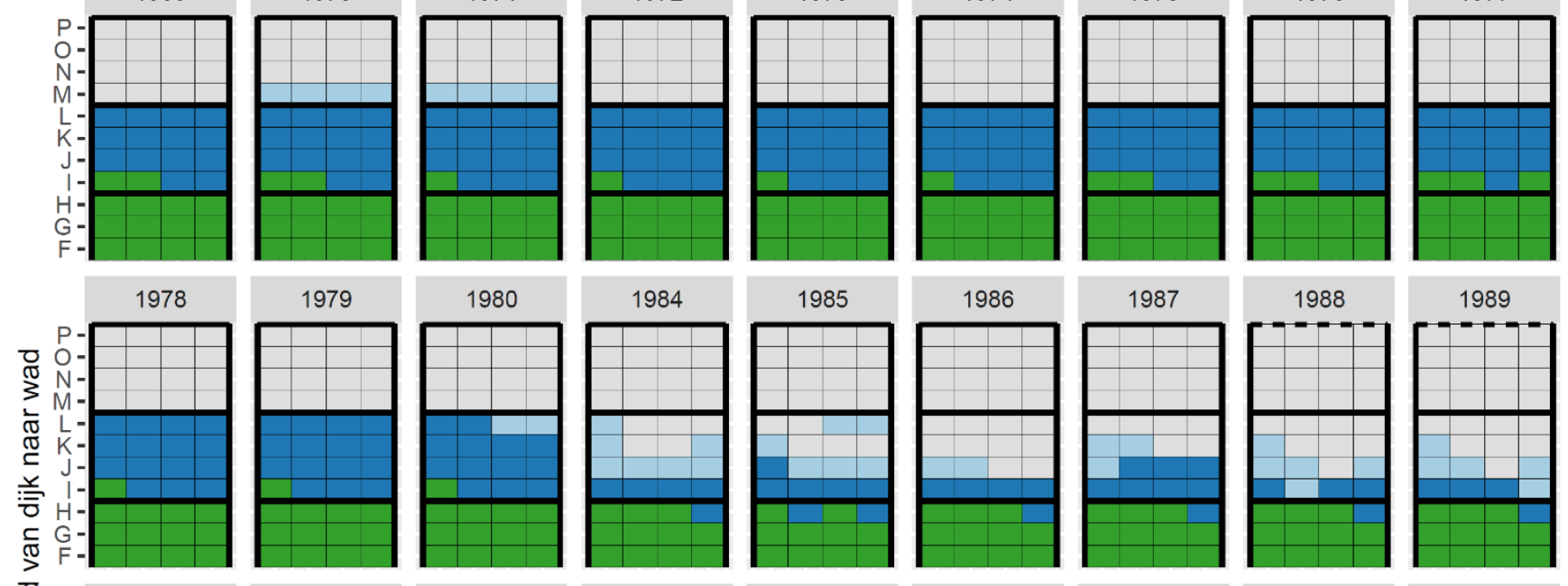

1988

1989
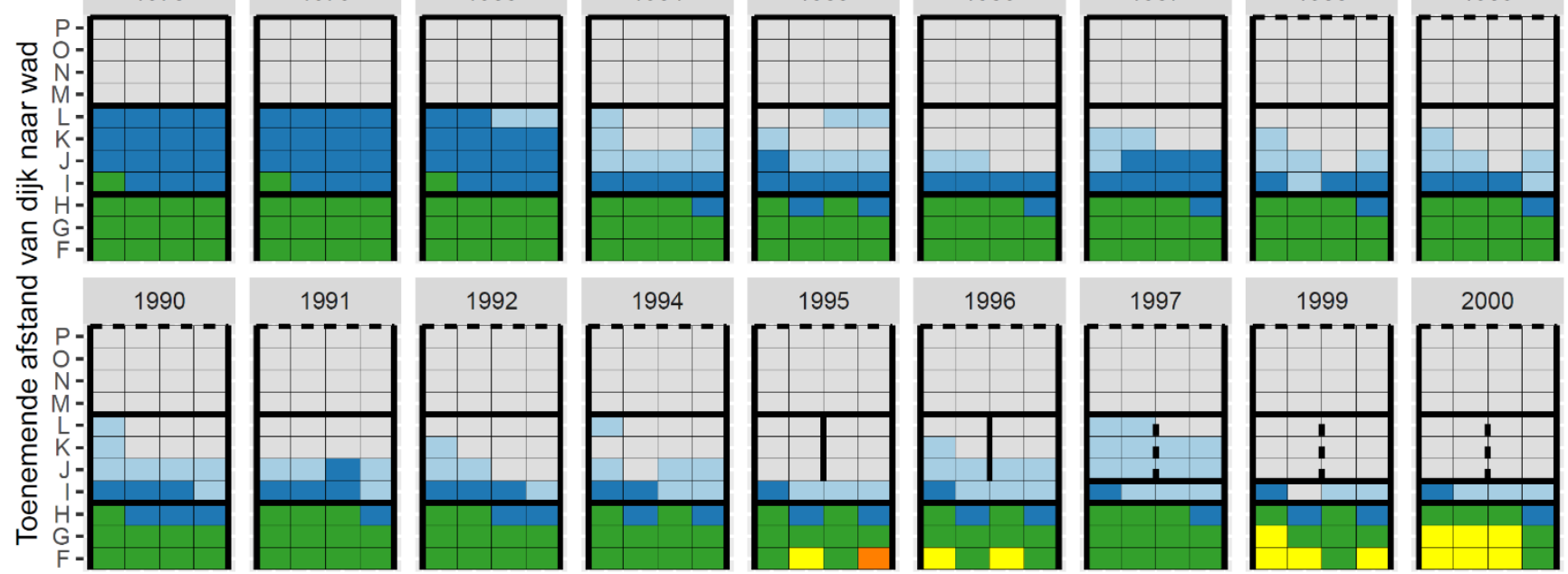

2000
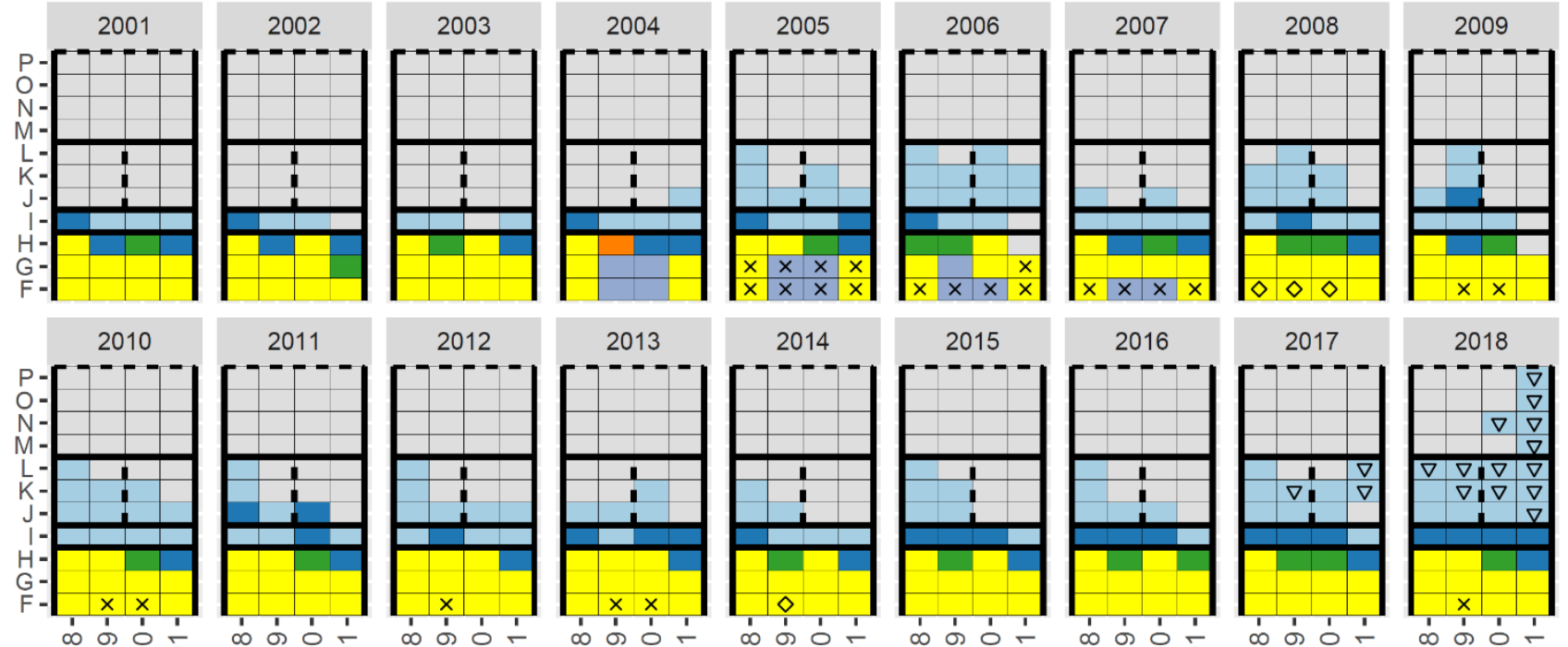

வ

它 MeetVaknummer

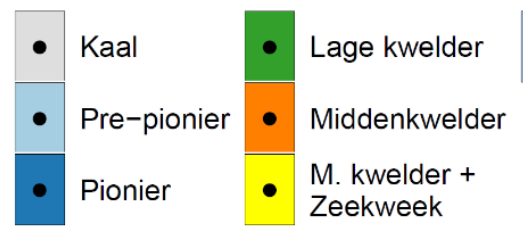

M. kwelder +
h. kwelder soorten

$\times \quad$ Vegetatie geïntrapoleerd

$\diamond$ Vegetatiekaart

Dam onderhouden

- Ja

$\nabla$ Zeegras 
Bijlage 6 Maaiveldverandering weergegeven per individueel meetvak 1965-2018 


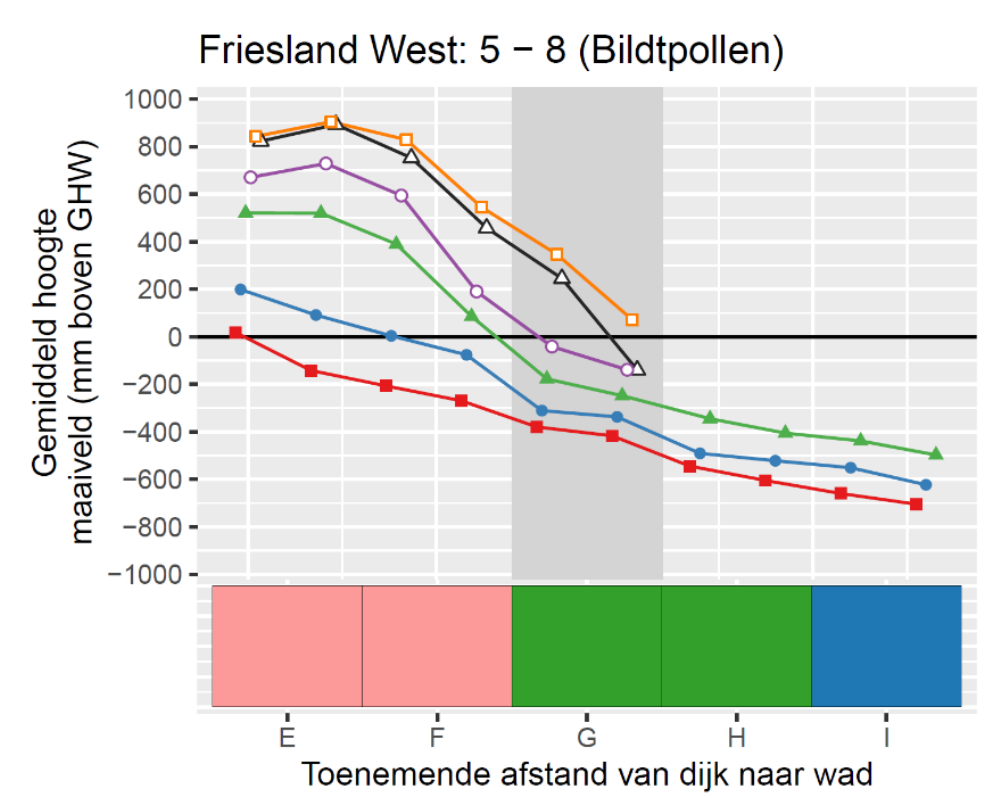

Jaar

$\rightarrow-1966$

$\rightarrow 1975$

$\simeq 1985$

- 1995

$-\square-2005$

$\triangle 2016$

Toenemende afstand van dijk naar wad

Pionier $\square$ kage $\square$ kwelder $\square$ Hoge kwelder

Bezinkveld 2

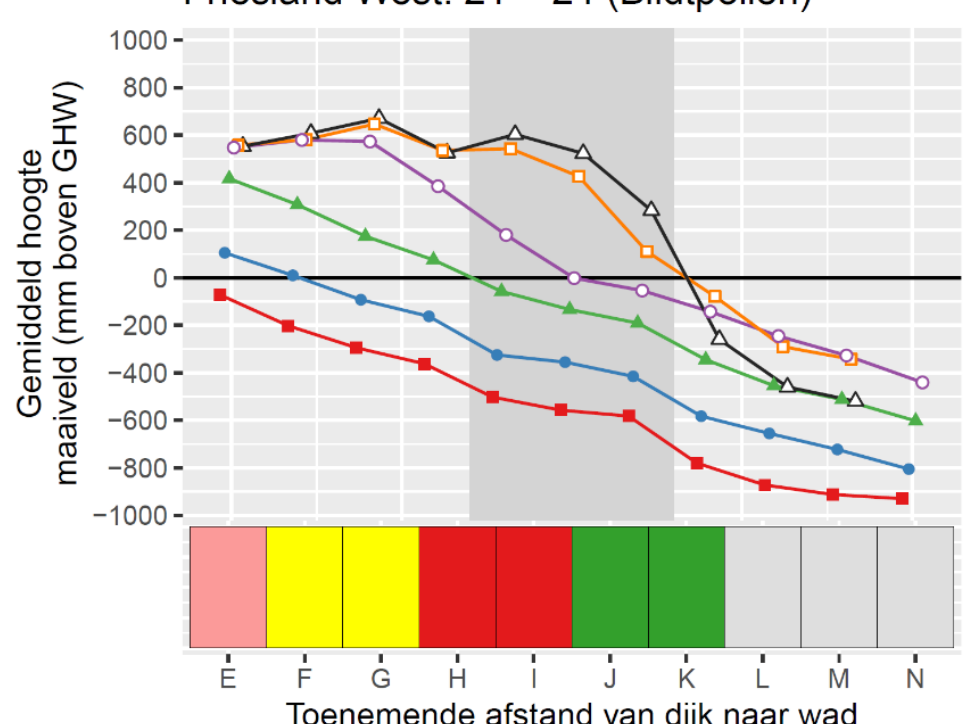

Bezinkveld 2

Jaar

$\rightarrow 1966$

$\rightarrow 1975$

$\leftarrow 1985$

- 1995

$-\square-2005$

$\triangle 2017$

Toenemende afstand van dijk naar wad

$\square$ Kaal $\begin{aligned} & \text { Lage } \\
& \text { kwelder } \square\end{aligned} \begin{aligned} & \text { M. kwelder }+\square \\
& \text { zeekweek }\end{aligned}$ Hoge kwelder \begin{tabular}{l}
$\begin{array}{l}\text { Hoge kwelder + } \\
\text { brak + zilt }\end{array}$ \\
\hline
\end{tabular}

\section{Friesland West: 53 - 56 (Bildtpollen)}

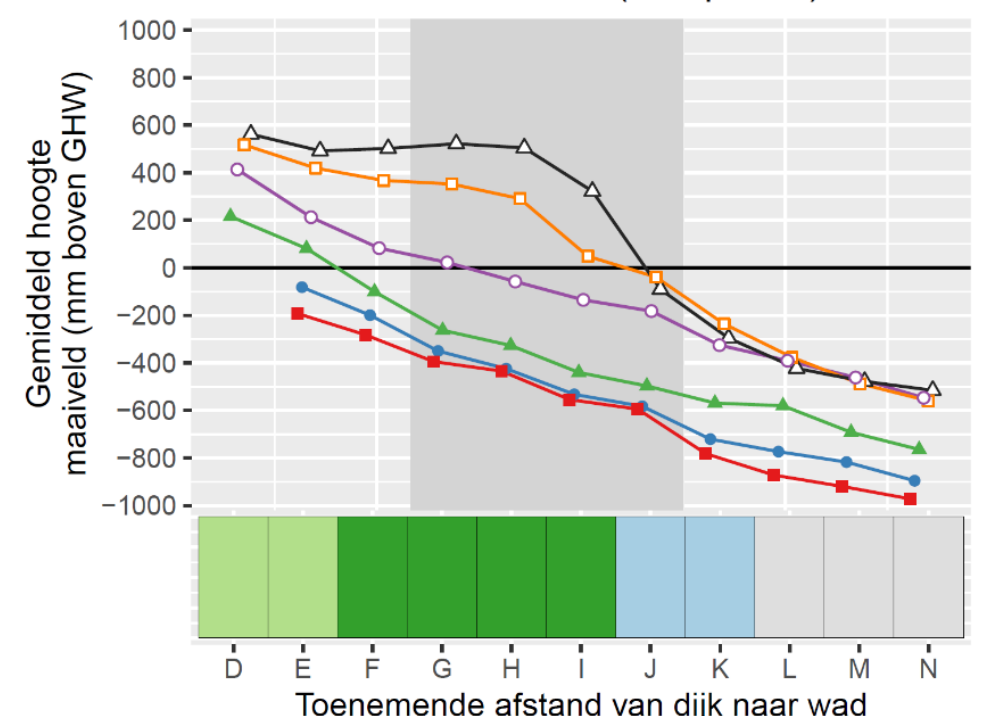

Jaar

$\rightarrow 1966$

$\rightarrow 1975$

$\sim 1985$

$-\infty 1995$

$-\square-2005$

$\triangle-\triangle 2018$

Bezinkveld 2

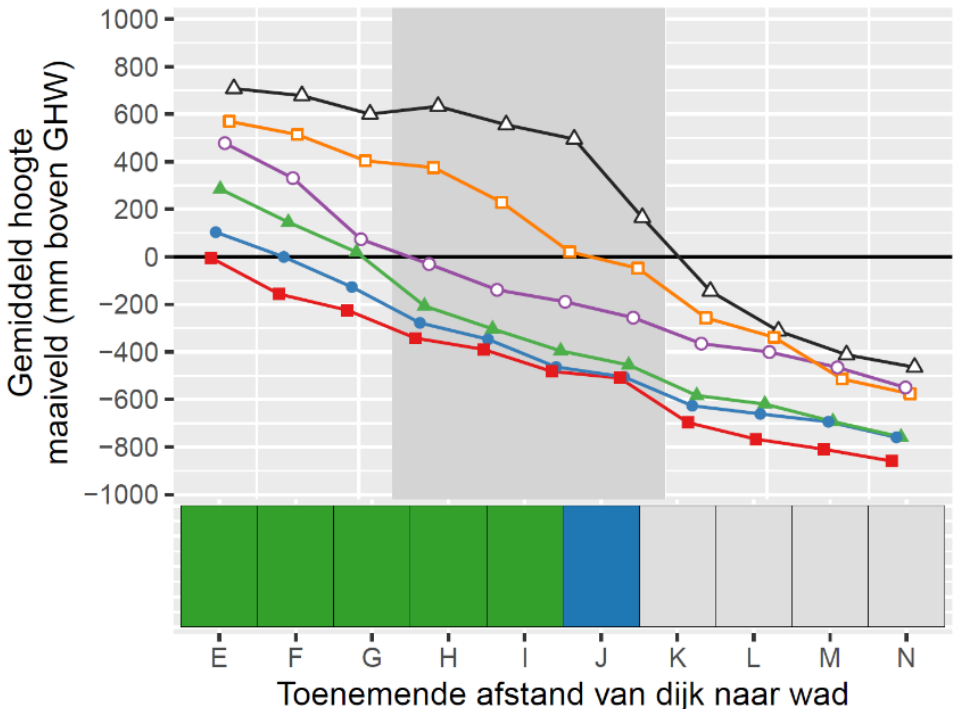

Bezinkveld 2

Jaar

$-1966$

$\rightarrow 1975$

$\neg 1985$

- 1995

$-\square-2005$

$\triangle 2017$

92 | wOt-technical report 182 


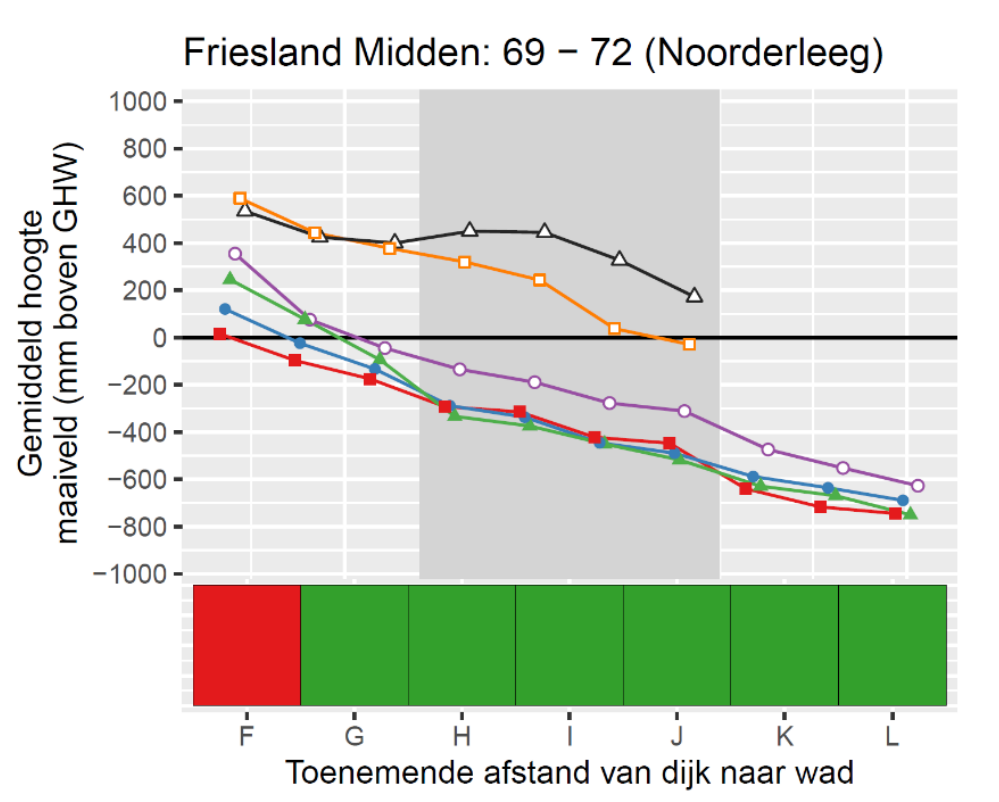

Jaar
-1966
$\rightarrow 1975$
$\simeq 1985$
$-\sim 1995$
$-\square 2005$
$-\triangle 2016$

Bezinkveld 2

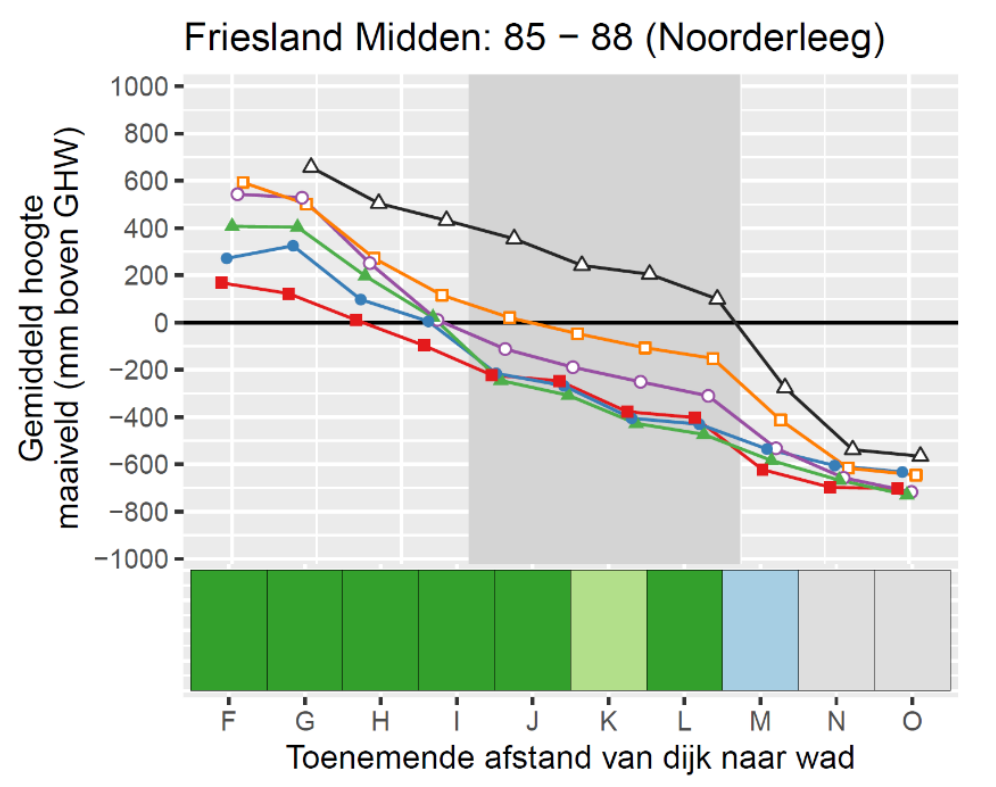

Jaar

$=1966$

$\rightarrow 1975$

$\simeq 1985$

- 1995

$-\square-2005$

$\triangle 2018$

Toenemende afstand van dijk naar wad

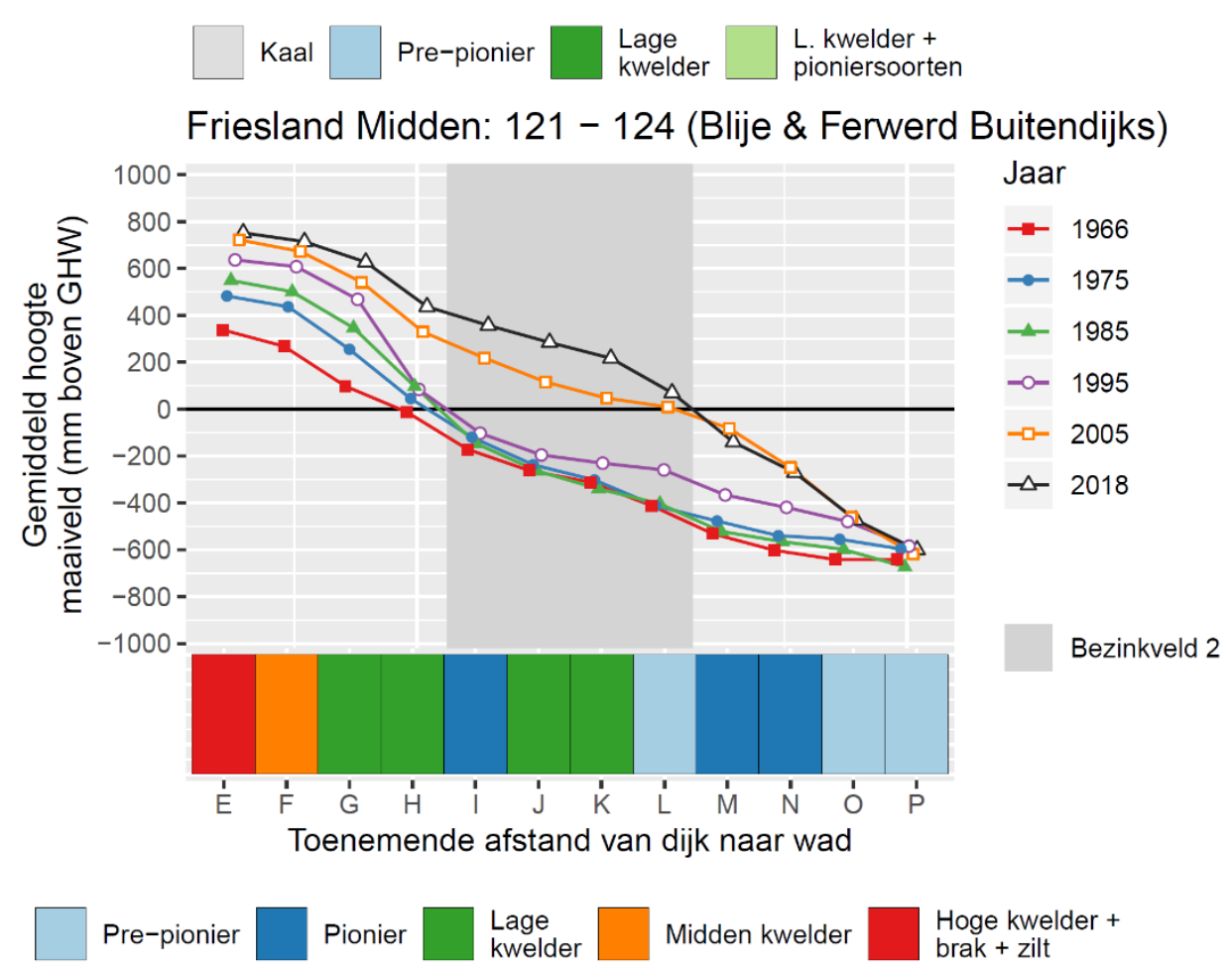

Lange-termijnontwikkeling van kwelders in de Waddenzee (1960-2018) | 93 
Friesland Midden: 145 - 148 (Blije \& Ferwerd Buitendijks)

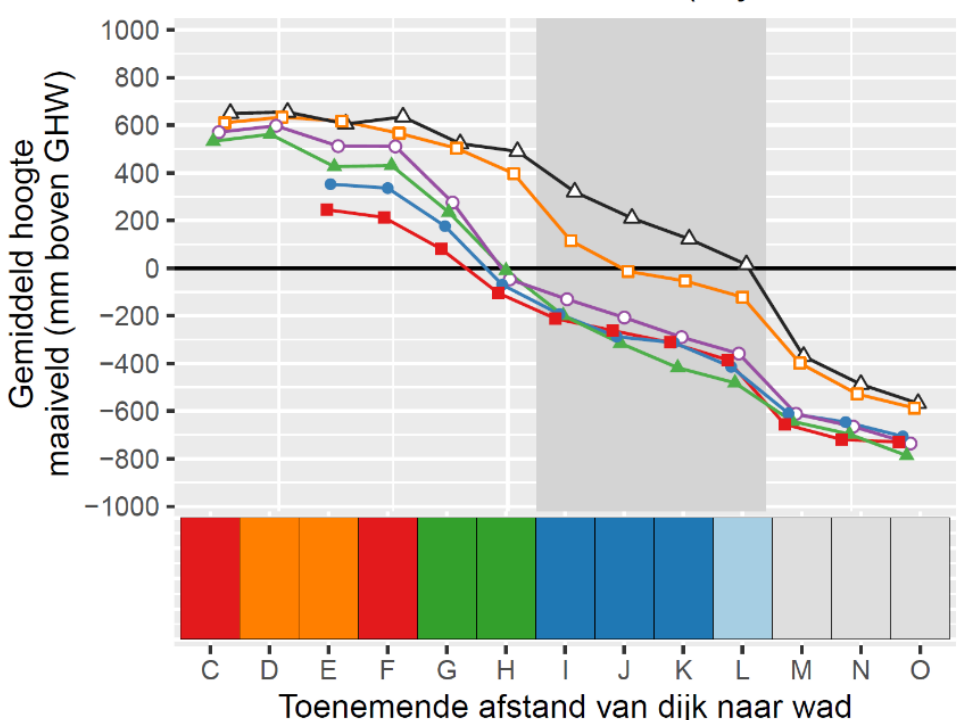

Jaar

$-1966$

$\rightarrow 1975$

$\simeq 1985$

- 1995

$-\square-2005$

$\triangle-2016$

Bezinkveld 2

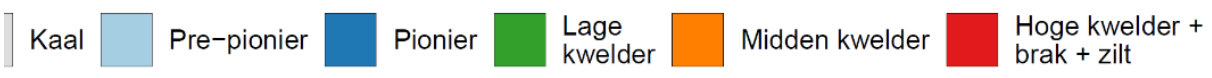

Friesland Midden: 183 - 186 (Holwerd Buitendijks West)

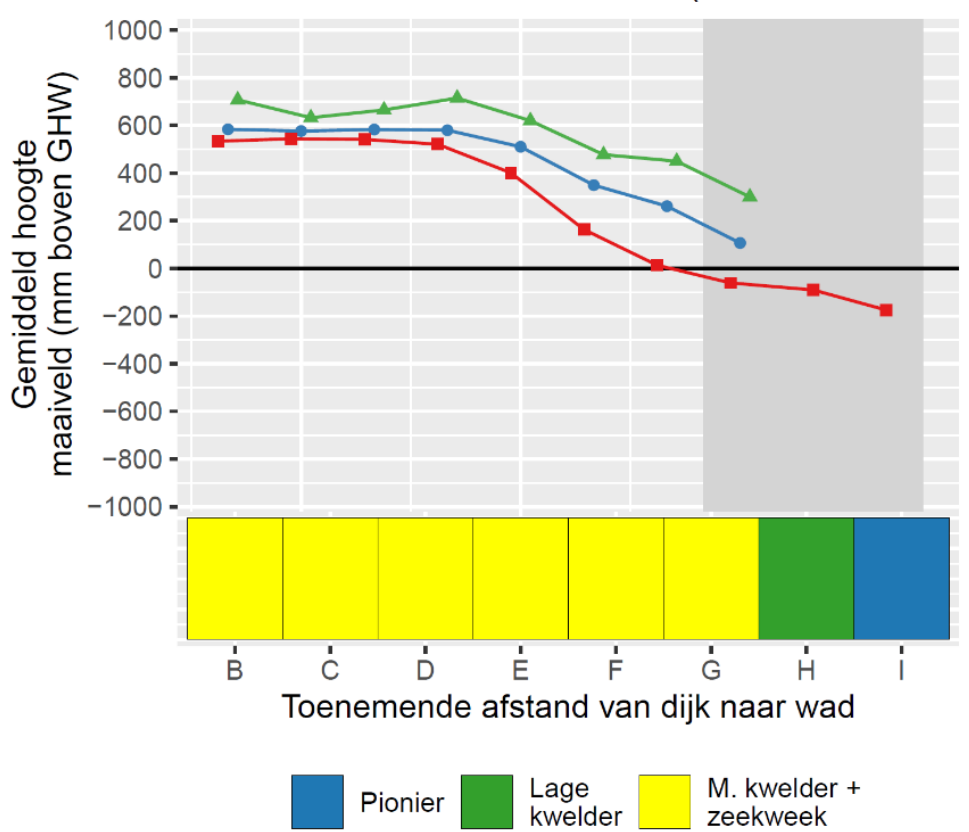

Jaar

$=1995$

$\rightarrow 2005$

$\simeq 2016$

Bezinkveld 2
Friesland Midden: 167 - 170 (Holwerd Buitendijks West)

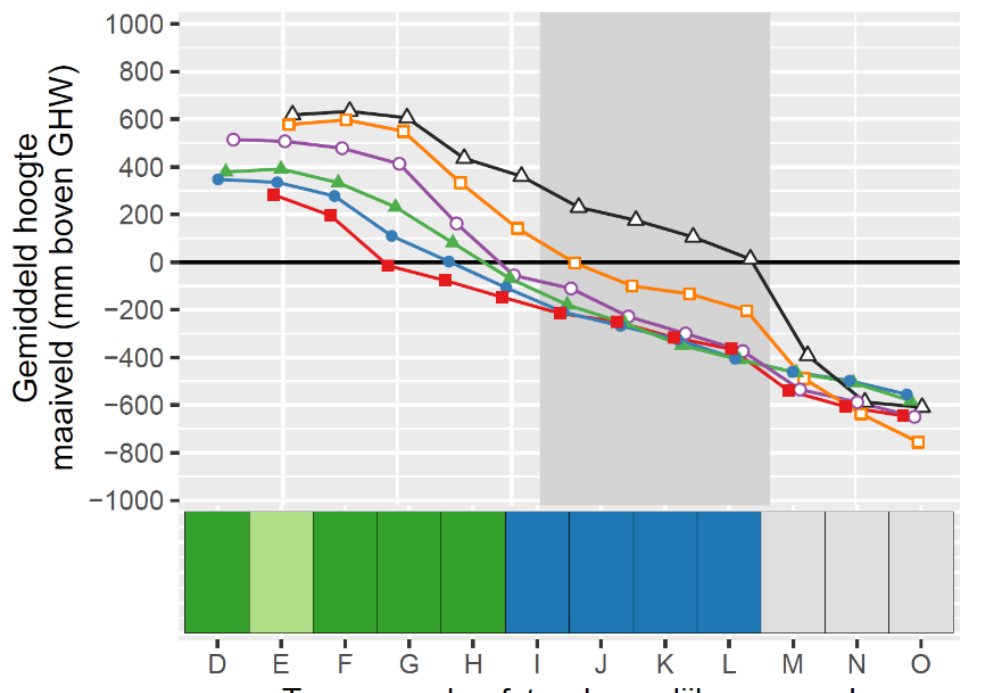

Bezinkveld 2

Jaar

$-1966$

$\rightarrow 1975$

$\simeq 1985$

$-1995$

$-\square-2005$

$\triangle 2017$ $\square$ Kaal $\square$ Pionier $\square \begin{aligned} & \text { Lage } \\ & \text { kwelder }\end{aligned}$

Friesland Oost: 205 - 208 (Holwerd Buitendijks Oost)

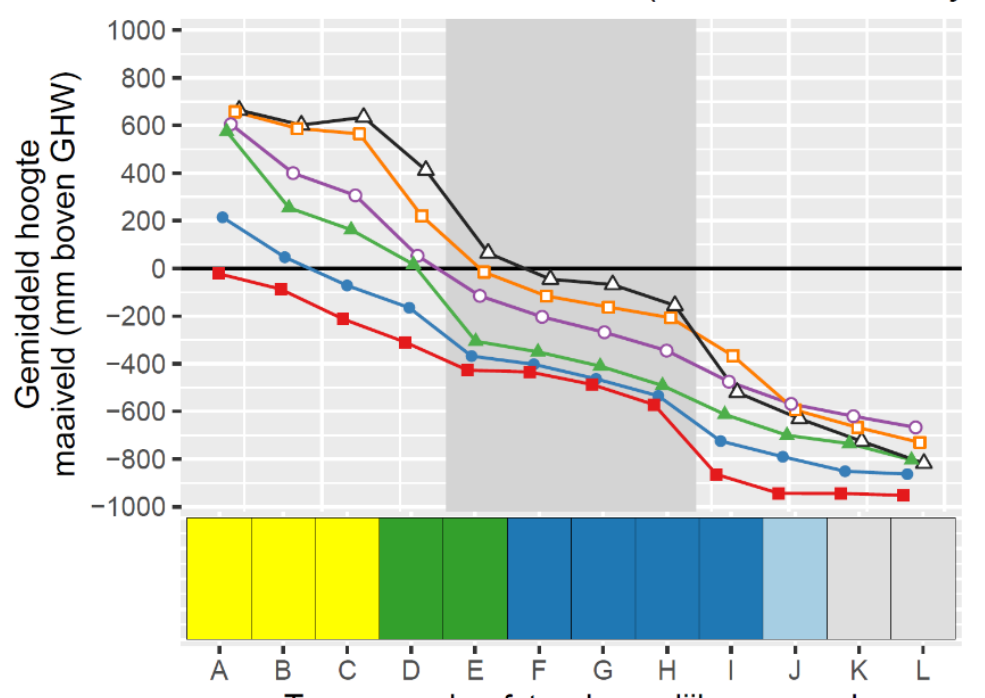

Jaar

$\rightarrow-1966$

$\rightarrow 1975$

$\simeq 1985$

$-\infty 1995$

$-\square-2005$

$\triangle-2018$

Bezinkveld 2

94 | wOt-technical report 182 


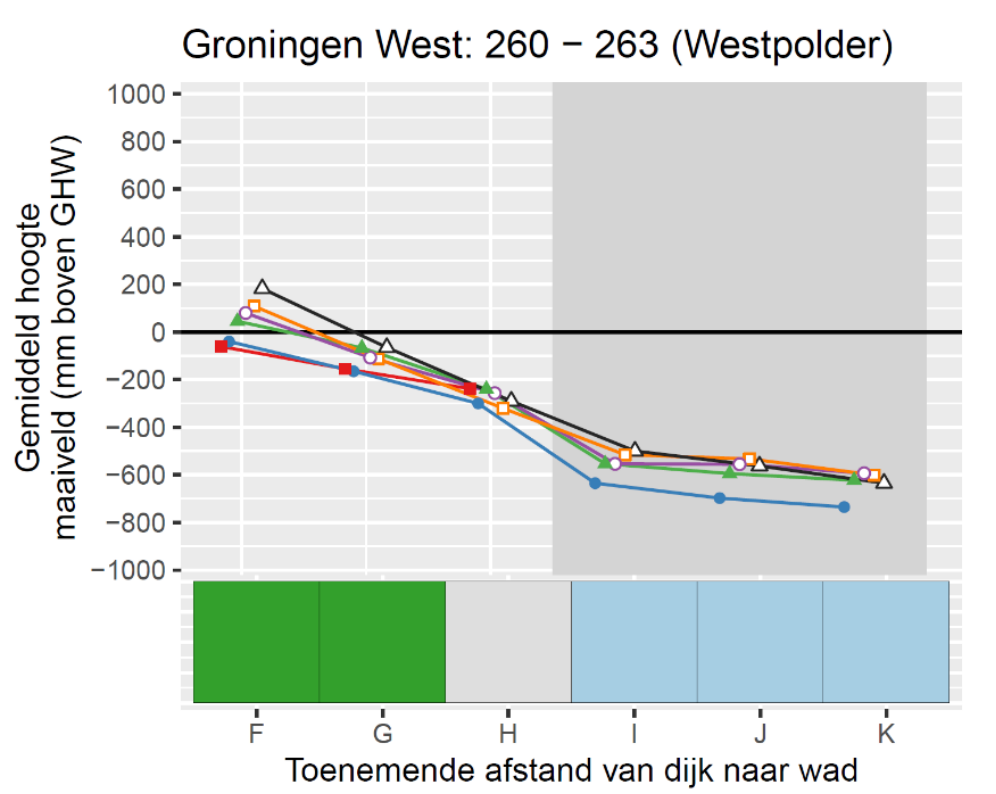

Jaar
-1966
$\rightarrow 1975$
$\simeq 1985$
$-\infty 1995$
$-\square 2005$
$-\triangle 2016$

Bezinkveld 2

Toenemende afstand van dijk naar wad

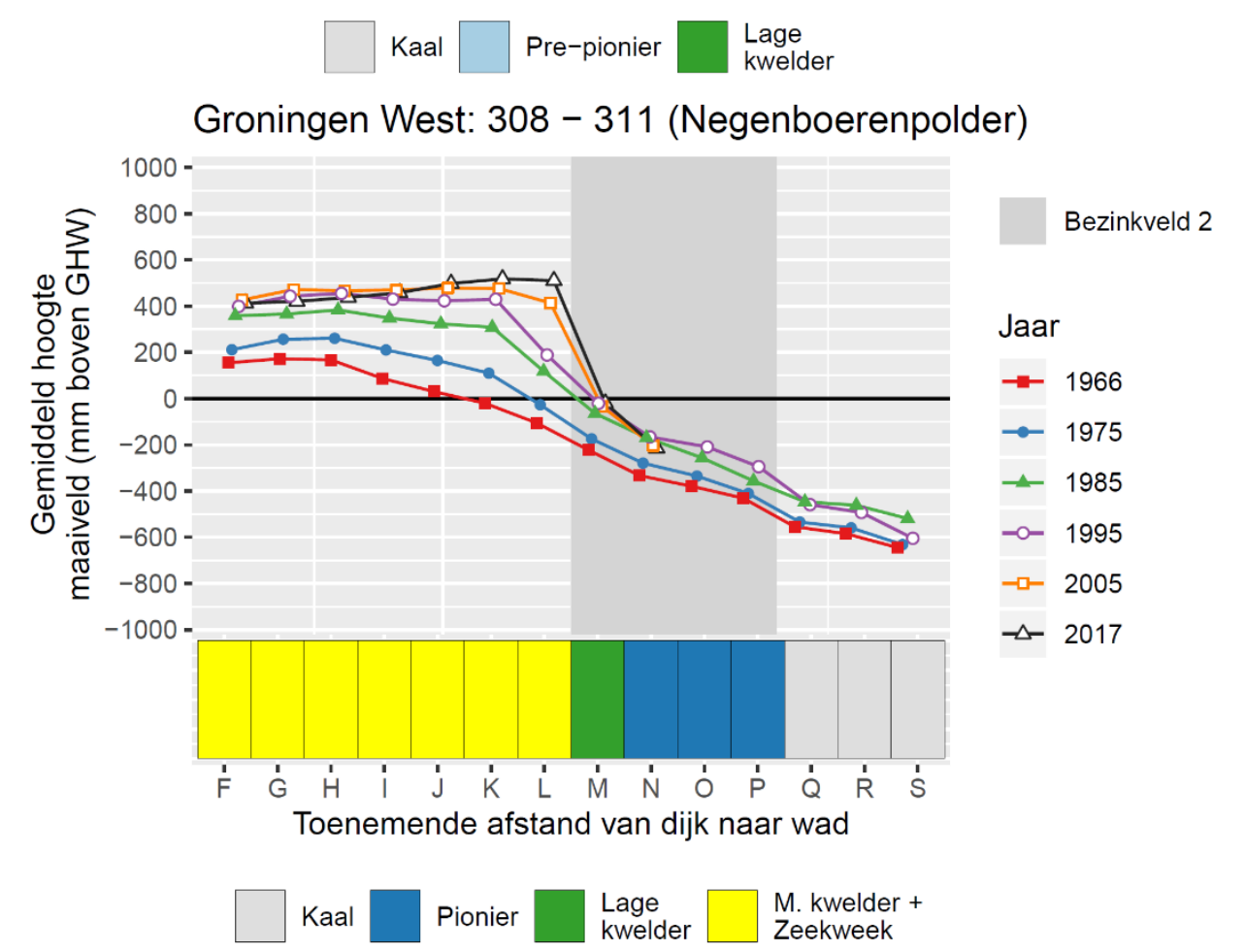

Jaar

$=1966$

$\rightarrow 1975$

$\simeq 1985$

$-0-1995$

$-\square-2005$

$\triangle 2018$

Bezinkveld 2

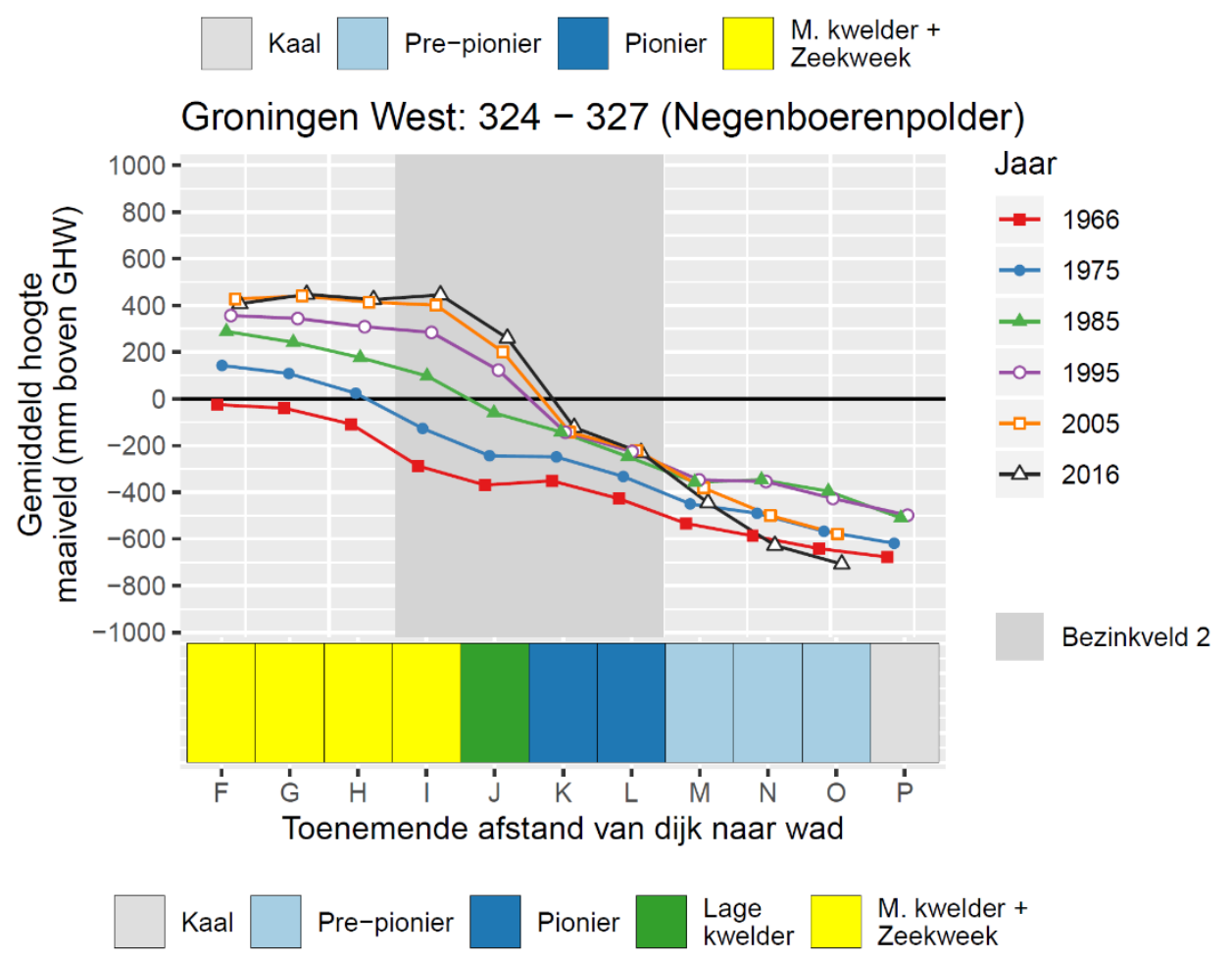

Lange-termijnontwikkeling van kwelders in de Waddenzee (1960-2018) | 95 

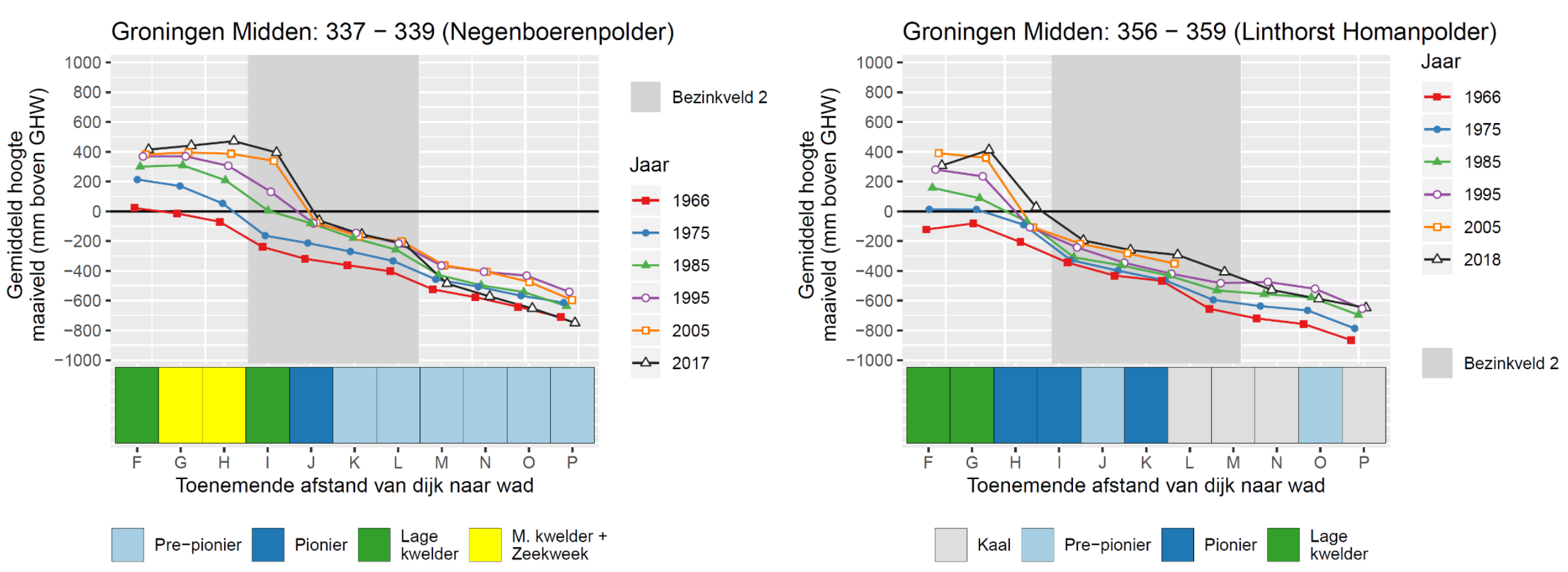

Groningen Midden: 372 - 375 (Linthorst Homanpolder)
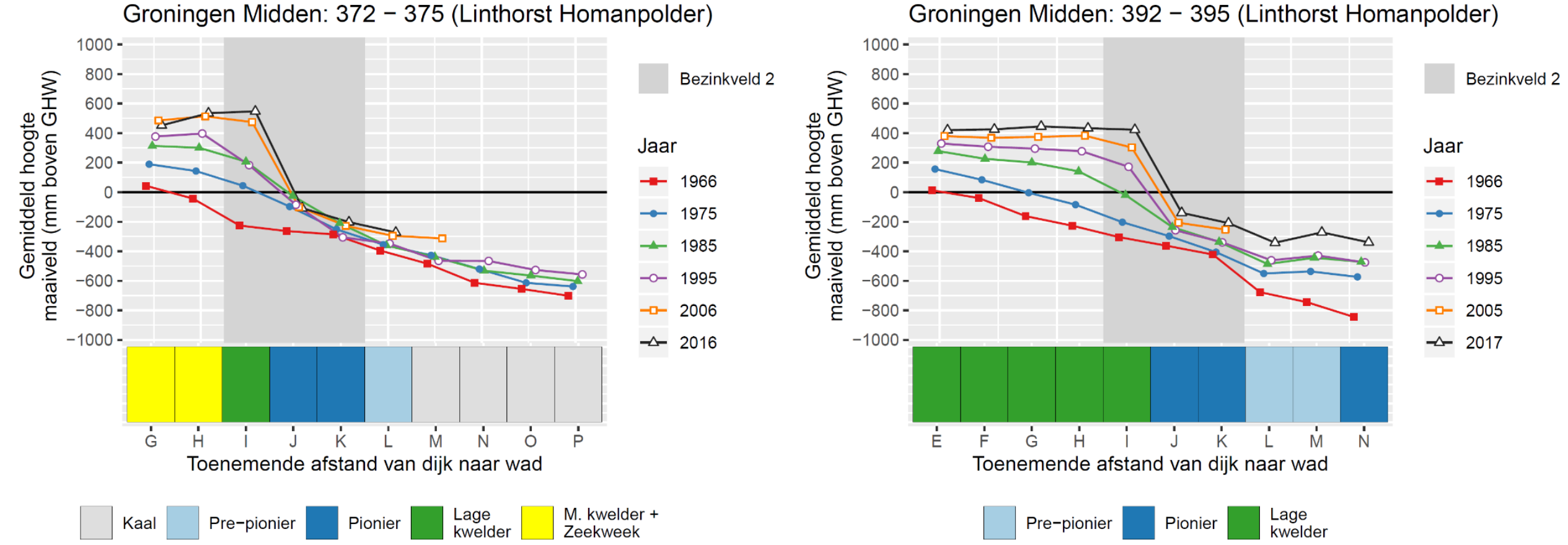

96 | wot-technical report 182 

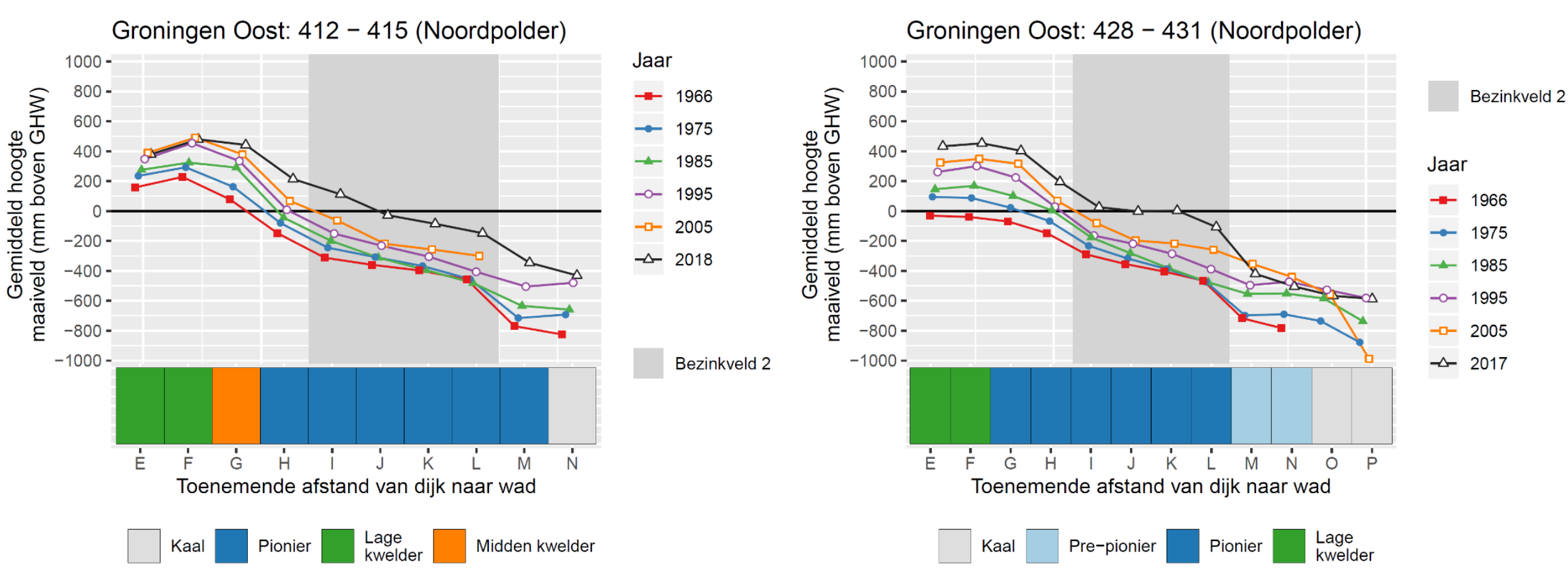

\section{Groningen Oost: 448 - 451 (Noordpolder)}
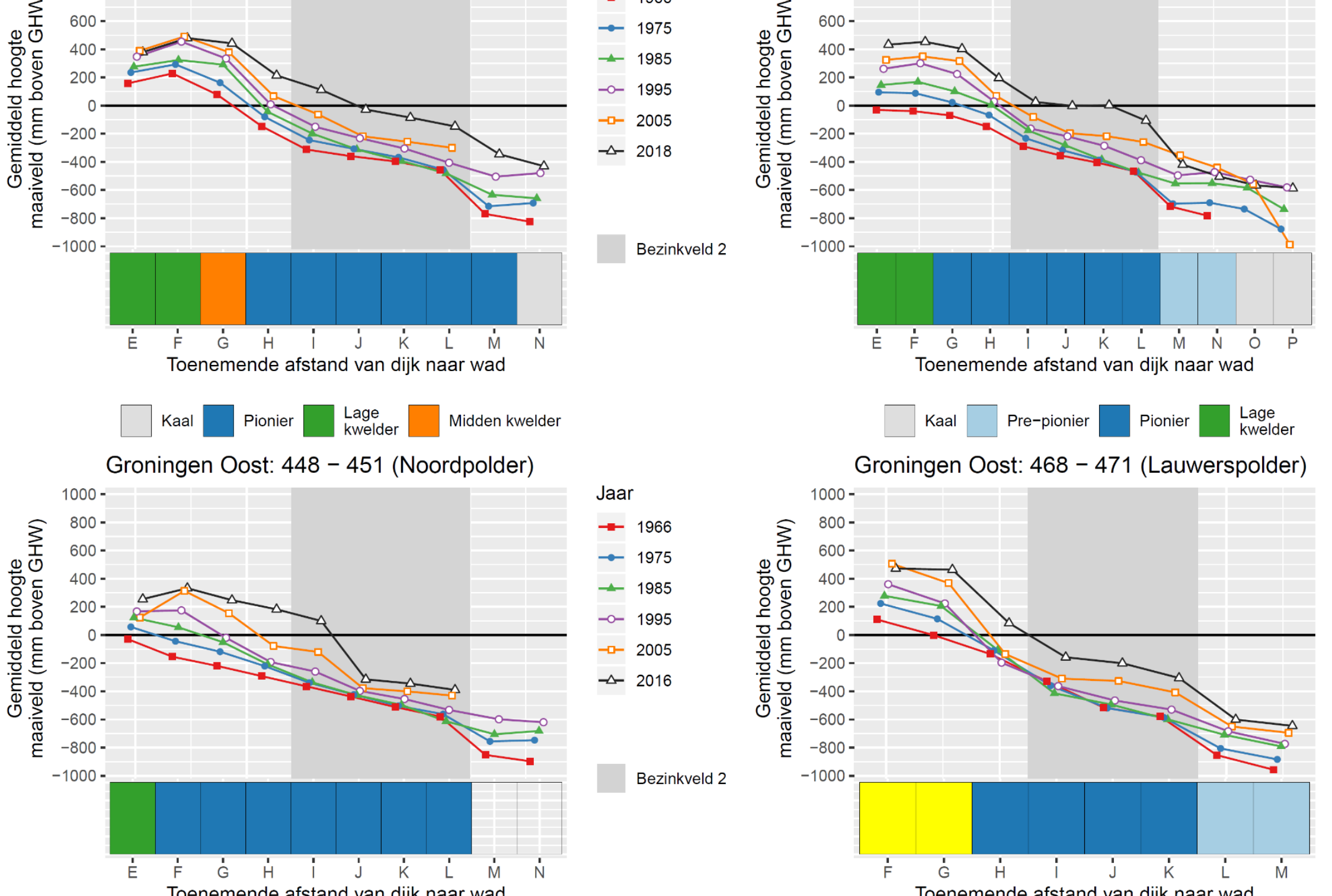

Jaar

Toenemende afstand van dijk naar wad

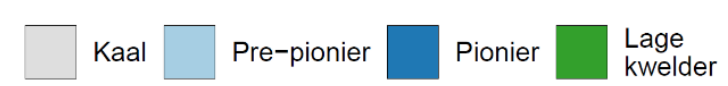

\section{Groningen Oost: 468 - 471 (Lauwerspolder)}

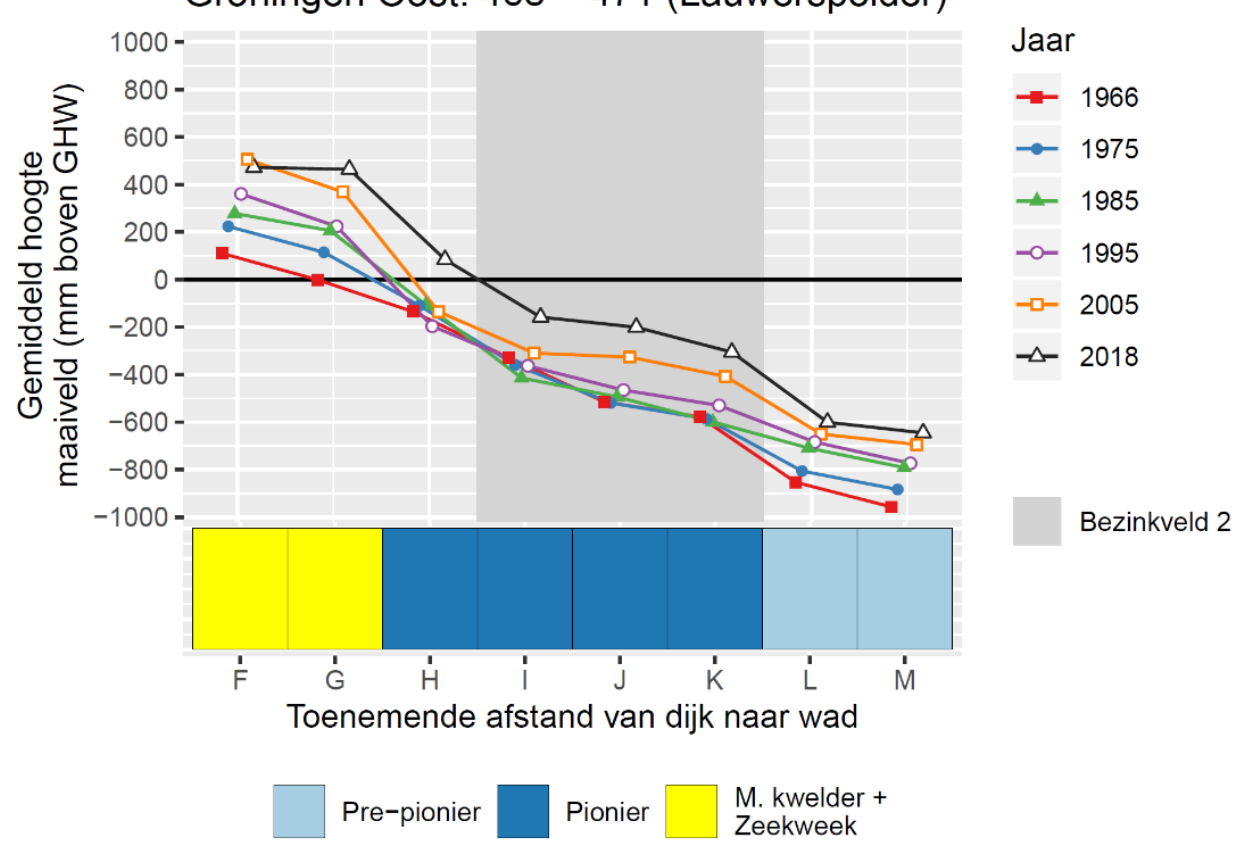

Lange-termijnontwikkeling van kwelders in de Waddenzee (1960-2018) | 97 


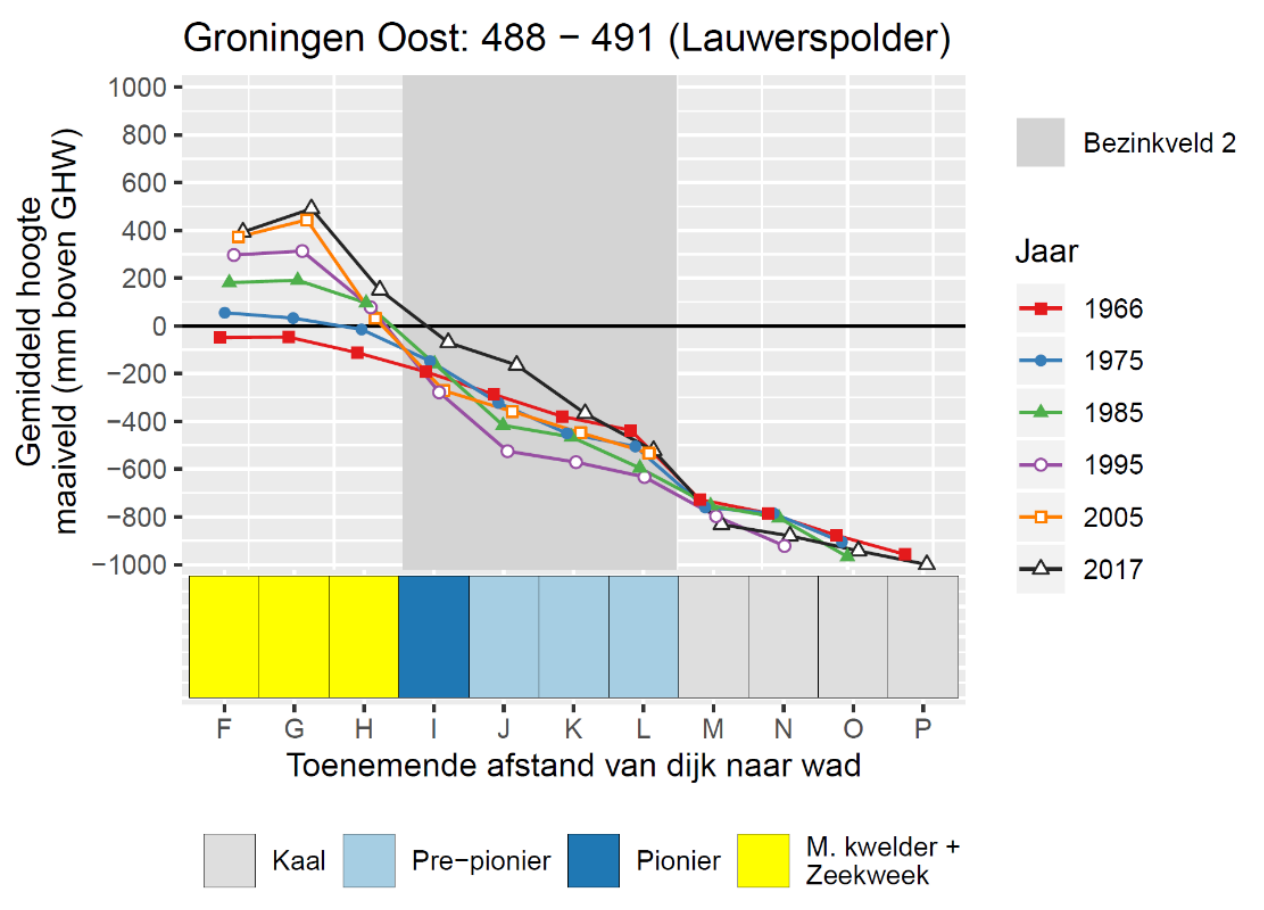


146 Arets, E.J.M.M., J.W.H van der Kolk, G.M. Hengeveld, J.P. Lesschen, H. Kramer, P.J. Kuikman \& M.J. Schelhaas (2019). Greenhouse gas reporting of the LULUCF sector in the Netherlands. Methodological background, update 2019.

147 Bruggen, C. van, A. Bannink, C.M. Groenestein, J.F.M. Huijsmans, L.A. Lagerwerf, H.H. Luesink, S.M. van der Sluis, G.L. Velthof \& J. Vonk (2019). Emissies naar lucht uit de landbouw in 2017. Berekeningen met het model NEMA.

148 Lagerwerf, L.A., A. Bannink, C. van Bruggen, C.M. Groenestein, J.F.M. Huijsmans, J.W.H. van der Kolk, H.H. Luesink, S.M. van der Sluis, G.L. Velthof \& J. Vonk (2019). Methodology for estimating emissions from agriculture in the Netherlands. Calculations of $\mathrm{CH} 4, \mathrm{NH} 3, \mathrm{~N} 2 \mathrm{O}$, NOX, NMVOC, PM10, PM2.5 and CO2 with the National Emission Model for Agriculture (NEMA) - update 2019.

149 Bakker, G., M. Heinen, H.P.A. Gooren, W.J.M. de Groot, F.B.T. Assinck \& E.W.J. Hummelink (2019). Hydrofysische gegevens van de bodem in de Basisregistratie Ondergrond (BRO) en het Bodemkundig Informatie Systeem (BIS); Update 2018.

150 IJsseldijk, L.L., M.J.L. Kik, \& A. Gröne (2019). Postmortaal onderzoek van bruinvissen (Phocoena phocoena) uit Nederlandse wateren, 2018. Biologische gegevens, gezondheidsstatus en doodsoorzaken.

151 Daamen, W.P., A.P.P.M. Clerkx \& M.J. Schelhaas (2019). Veldinstructie Zevende Nederlandse Bosinventarisatie (2017-2021); Versie 2.0.

152 Bikker, P., L.B. Šebek, C. van Bruggen \& O. Oenema (2019). Stikstof- en fosfaatexcretie van gangbaar en biologisch gehouden landbouwhuisdieren. Herziening excretieforfaits Meststoffenwet 2019

153 Berg, F. van den, H. Baveco \& E.L. Wipfler (2019). User manual for SAFE (Select Application date For Evaluation) to support the use of the GEM scenarios for cultivations in glasshouses; Version 1.1

154 Os, J. van, L.J.J. Jeurissen en H.H. Ellen (2019). Rekenregels pluimvee voor de Landbouwtelling; Verantwoording van het gebruik van het Identificatie- \& Registratiesysteem.

155 Brouwer, F. \& D.J.J. Walvoort (2019). Basisregistratie Ondergrond (BRO) Actualisatie bodemkaart; Herkartering van de veengebieden in Eemland

156 Sanders, M.E., R.J.H.G. Henkens \& D.M.E. Slijkerman (2019). Convention on Biological
Diversity; Sixth National Report of the Kingdom of the Netherlands.

157 Kuiters, A.T., G.A. de Groot, D.R. Lammertsma, H.A.H. Jansman, J. Bovenschen, M.C. Boerwinkel \& M. Laar (2019). Genetische monitoring van de Nederlandse otterpopulatie; Ontwikkeling van populatieomvang en genetische status 2018/2019.

158 Sanders, M.E. \& H.A.M. Meeuwsen (2019). Basisbestand Natuur en Landschap.

159 Visser, T., H.A.M Meeuwsen \& Th.C.P. Melman (2019). MNP-(Model for Nature Policy) Agrarisch; Uitwerking voor scenario's uit de Natuurverkenning 2020.

160 Jong, A. de, A. Poot \& P.I. Adriaanse (2019). Impact analysis for the purpose of the introduction of DROPLET version 1.3.2.

161 Westerink, J., T.A. de Boer, M. Pleijte \& R.A.M. Schrijver (2019). Kan een goede boer natuurinclusief zijn?; De rol van culturele normen in een beweging richting natuurinclusieve landbouw.

162 Buijs, A.E., F.G. Boonstra (2020). Natuurbeleid betwist; Visies op legitimiteit en natuurbeleid.

163 Haas, W. de, J.L.M. Donders, T.J.M. Mattijssen (2019). Natuur in conflict; Botsende waarden, waarheden en belangen in het natuurbeheer.

164 Berg, F. van den, A. Tiktak, D. van Kraalingen \& J.J.T.I. Boesten (2019). User manual for FOCUSPEARL version 5.5.5.

165 Glorius, S.T., A. Meijboom, J. Schop \& J.T. van der Wal (2019). Ontwikkeling van enkele droogvallende mosselbanken in de Nederlandse Waddenzee; situatie 2018.

166 Pedroli, B, During, R. (2019). De paradox van een maakbare natuur - ingebakken en omstreden; Betekenis culturele identiteit voor draagvlak natuurbeleid en -beheer.

167 Walvoort, D.J.J., M. Knotters, F.M. van Egmond (2019). Interpolatie, aggregatie en desaggregatie van ruimtelijke bodemgegevens in de Basisregistratie Ondergrond (BRO).

168 Arets, E.J.M.M., J.W.H van der Kolk, G.M. Hengeveld, J.P. Lesschen, H. Kramer, P.J. Kuikman \& M.J. Schelhaas (2020). Greenhouse gas reporting of the LULUCF sector in the Netherlands. Methodological background, update 2020.

170 Bos-Groenendijk, G.I., C.A.M van Swaay (2020). Habitatrichtlijnrapportage 2019: Annex B Habitatrichtlijnsoorten; Achtergronddocument.

171 Janssen, J.A.M. (red.), R.J. Bijlsma (red.), G.H.P. Arts, M.J. Baptist, S.M. Hennekens, B. de Knegt, T. van der Meij, J.H.J. Schaminée, A.J. 
van Strien, S. Wijnhoven, T.J.W. Ysebaert (2020). Habitatrichtlijnrapportage 2019: Annex D Habitattypen. Achtergronddocument.

172 Van Kleunen, A., M. van Roomen, E. van Winden, M. Hornman, A. Boele, C. Kampichler, D. Zoetebier, H. Sierdsema \& C. van Turnhout (2020). Vogelrichtlijnrapportage 2013-2018 van Nederland - status en trends van soorten.

173 Glorius, S.T., A. Meijboom (2020). Ontwikkeling van de bodemdiergemeenschap in de geulen van referentiegebied Rottum; Tussenrapportage 13 jaar na sluiting (najaar 2018).

174 Kuindersma, W., D. van Doren, R. Arnouts, D.A. Kamphorst, J.G. Nuesink, E. de Wit-de Vries (2020). Realisatie Natuurnetwerk door provincies. Achtergrondstudie bij de Tweede Lerende Evaluatie Natuurpact.

175 Bouwma, I.M., D.A. Kamphorst, D. van Doren, T.A. de Boer, A.E. Buijs, C.M. Goossen, J.L.M. Donders, J.Y. Frissel, S. van Broekhoven (2020). Provinciaal beleid voor maatschappelijke betrokkenheid bij natuur het beleid nader bekeken in 8 casussen. Achtergrondstudie bij de Tweede Lerende Evaluatie Natuurpact.

176 Gerritsen, A.L., H. Agricola, C. Aalbers, J. van Os (2020). Natuur en landbouw verbinden. Achtergrondstudie bij de Tweede Lerende Evaluatie Natuurpact.

177 Brouwer, F., D.J.J. Walvoort (2020). Basisregistratie Ondergrond (BRO) Actualisatie bodemkaart. Herkartering van de veengebieden aan de flanken van de Utrechtse Heuvelrug.
178 Bruggen, C. van, A. Bannink, C.M. Groenestein, J.F.M. Huijsmans, L.A. Lagerwerf, H.H. Luesink, G.L. Velthof \& J. Vonk (2020). Emissies naar lucht uit de landbouw, 1990-2018; Emissies van ammoniak, stikstofoxide, lachgas, methaan, niet-methaan vluchtige organische stoffen, fijnstof en koolstofdioxide uit kalkmeststoffen - Berekeningen met het model NEMA.

179 Knegt, de B., M. Pleijte, E. de Wit-de Vries, I. Bouwma, F. Kistenkas, W. Nieuwenhuizen (2020). Samenhang Klimaatakkoord en natuurbeleid. Proces en implementatie van het Klimaatakkoord door provincies en maatschappelijke partijen en de potentiële effecten op biodiversiteitsdoelen van de Vogelen Habitatrichtlijn.

180 Mattijssen T.J.M., M. Pleijte, J. Dengerink, T. Koster, M. Visscher (2020). Indicatoren voor burgerbetrokkenheid bij natuur: een zoektocht naar nieuwe aanknopingspunten voor monitoring.

182 Elschot K., M.E.B. Van Puijenbroek, D.D.G. Lagendijk, J-T. Van der Wal, C. Sonneveld (2020). Lange-termijnontwikkeling van kwelders in de Waddenzee (1960-2018).

183 Koffijberg K., P. de Boer, S.C.V. Geelhoed, J. Nienhuis, K. Oosterbeek, J. Postma (2020). Broedsucces van kustbroedvogels in de Waddenzee in 2018.

184 IJsseldijk, L.L., M.J.L. Kik, L. van Schalkwijk \& A. Gröne (2020). Postmortaal onderzoek van bruinvissen (Phocoena phocoena) uit Nederlandse wateren, 2019. Biologische gegevens, gezondheidsstatus en doodsoorzaken. 



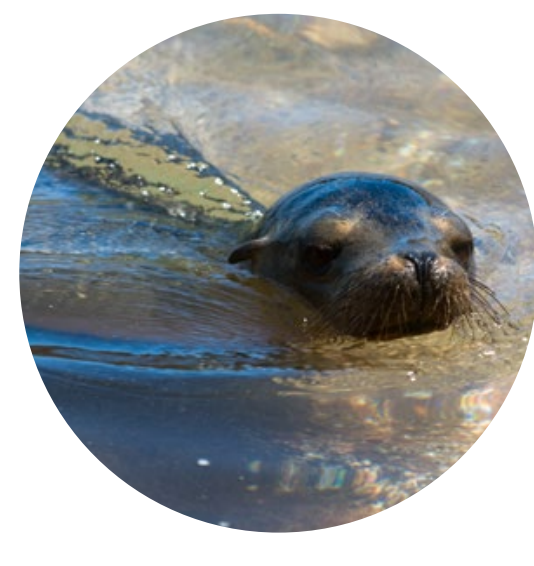

Thema Informatievoorziening Natuur Wettelijke Onderzoekstaken Natuur \& Milieu

Postbus 47

6700 AA Wageningen

T (0317) 485471

E info.wnm@wur.nl

ISSN 2352-2739

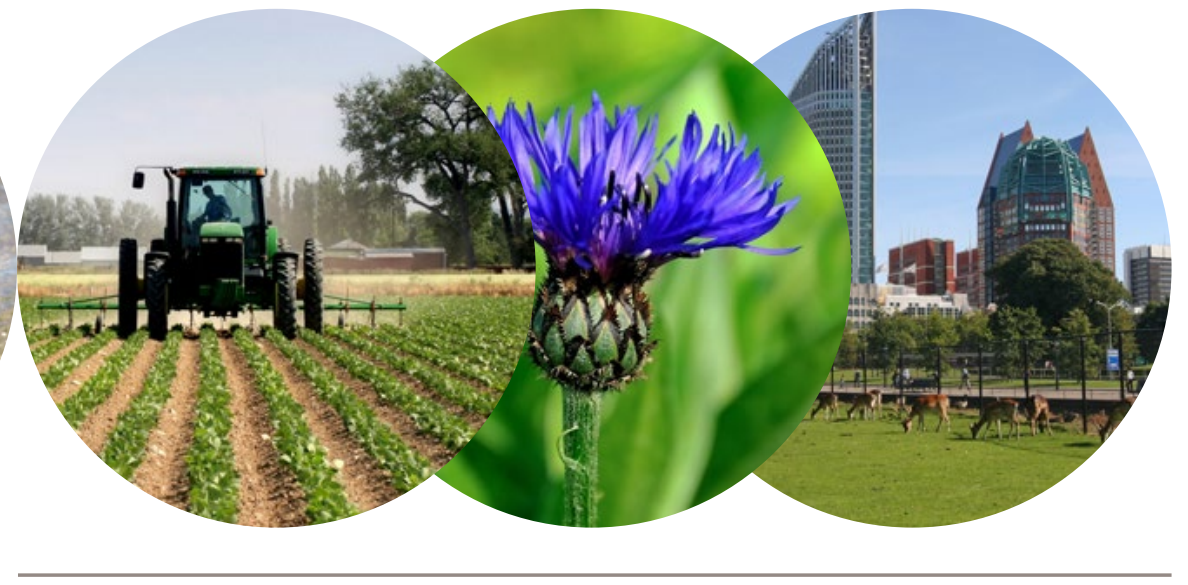

De missie van Wageningen University \& Research is 'To explore the potential of nature to improve the quality of life'. Binnen Wageningen University \& Research bundelen Wageningen University en gespecialiseerde onderzoeksinstituten van Stichting Wageningen Research hun krachten om bij te dragen aan de oplossing van belangrijke vragen in het domein van gezonde voeding en leefomgeving. Met ongeveer 30 vestigingen, 6.500 medewerkers en 12.500 studenten behoort Wageningen University \& Research wereldwijd tot de aansprekende kennisinstellingen binnen haar domein. De integrale benadering van de vraagstukken en de samenwerking tussen verschillende disciplines vormen het hart van de unieke Wageningen aanpak. 